\title{
HUBER RIZZO
}

Estudo da ocorrência e avaliação clínica de enfermidades do trato genital de ovinos (Ovis aries, Linnaeus, 1758) criados no estado de São Paulo 


\section{Huber Rizzo}

Estudo da ocorrência e avaliação clínica de enfermidades do trato genital de ovinos (Ovis aries, Linnaeus, 1758) criados no estado de São Paulo

Tese apresentada ao Programa de PósGraduação em Clínica Veterinária da Faculdade de Medicina Veterinária e Zootecnia da Universidade de São Paulo para obtenção do título de Doutor em Ciências

Departamento:

Clínica Médica

Área de concentração:

Clínica Veterinária

Orientador:

Prof.a Dra . Lilian Gregory

São Paulo 
Autorizo a reprodução parcial ou total desta obra, para fins acadêmicos, desde que citada a fonte.

DADOS INTERNACIONAIS DE CATALOGAÇÃO-NA-PUBLICAÇÃO

(Biblioteca Virginie Buff D’Ápice da Faculdade de Medicina Veterinária e Zootecnia da Universidade de São Paulo)

Rizzo, Huber

Estudo da ocorrência e avaliação clínica de enfermidades do trato genital de ovinos (Ovis aries, Linnaeus, 1758) criados no estado de São Paulo / Huber Rizzo. -- 2011.

$217 \mathrm{f}$. : il.

Tese (Doutorado) - Universidade de São Paulo. Faculdade de Medicina Veterinária e Zootecnia. Departamento de Clínica Médica, São Paulo, 2011.

Programa de Pós-Graduação: Clínica Veterinária.

Área de concentração: Clínica Veterinária.

Orientador: Prof. ${ }^{a}$ Dr ${ }^{a}$. Lilian Gregory.

1. Ovino. 2. Brucella ovis. 3. Campilobacteriosec. 4. Leptospirose. 5. Neosporose. 6. Toxoplasmose. I. Título. 


\section{UNIVERSIDADE DE SÃO PAULO \\ Faculdade de Medicina Veterinária e Zootecnia \\ Comissão Bioética}

\section{CERTIFICADO}

Certificamos que o Projeto intitulado "Avaliação clínica e ocorrência das principais enfermidades do trato genital de ovinos (Ovis áries, Linnaeus, 1758) nas regiões de Bragança Paulista, Ibiúna e Piedade e influência na produtividade do Rebanho", protocolado sob o n $1153 / 2007$, utilizando 1000 (mil) ovinos, sob a responsabilidade da Profa Dra Lílian Gregory, está de acordo com os princípios éticos de experimentação animal da Comissão de Bioética da Faculdade de Medicina Veterinária e Zootecnia da Universidade de São Paulo e foi aprovado "ad referendum".

(We certify that the Research "Clinical evaluation of the infectious reproduction diseases on ovine (Ovis aries, Linnteeus, 1758) at the Bragança Paulista, Ibiúna and Piedade regions and influence in the herd productivity", protocol number 1153/2007, utilizing 1000 (one thousand) ovine, under the responsibility Profa Dra Lilian Gregory, agree with Ethical Principles in Animal Research adopted by Bioethic Commission of the School of Veterinary Medicine and Zootechny of University of São Paulo and was approved "ad referendum", meeting.

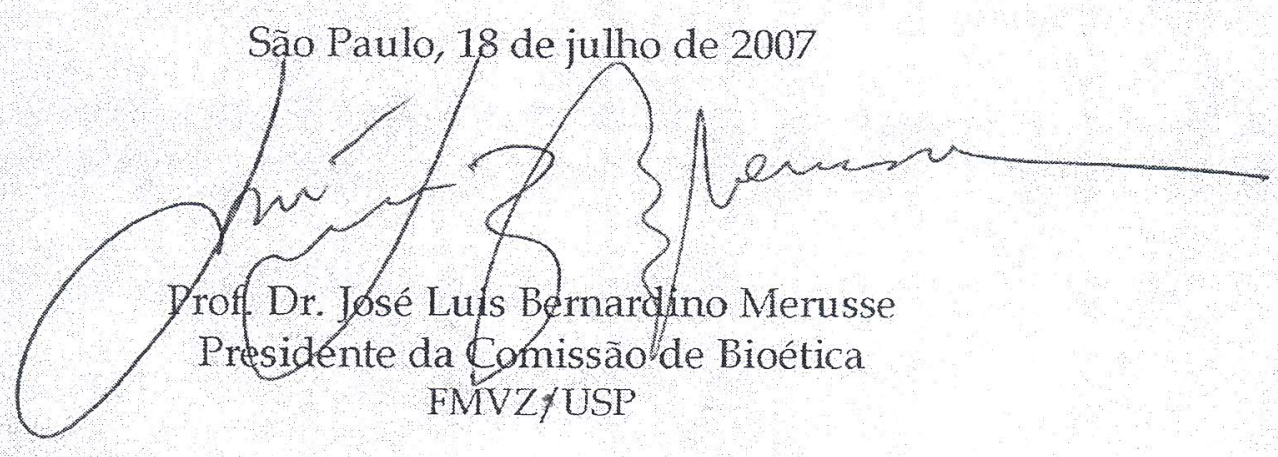

Av. Prof. Dr. Orlando Marques de Paiva, $\mathrm{n}^{\circ} 87$-05508-270 - Cidade Universitária "Armando de Salles Oliveira". Fax: (11) 3032-2224 - fones: (11) 309107676/7671 - e-mail: fmvz@edu.usp.br 


\section{FOLHA DE AVALIAÇÃO}

Nome: RIZZO, Huber

Título: Estudo da ocorrência e avaliação clínica de enfermidades do trato genital de ovinos (Ovis aries, Linnaeus, 1758) criados no estado de São Paulo

Tese apresentada do Programa de PósGraduação em Clínica Veterinária da Faculdade de Medicina Veterinária e Zootecnia da Universidade de São Paulo para obtenção do título de Doutor em Ciências

Data:

1

\section{Banca Examinadora}

Prof. Dr.

Julgamento:

Prof. Dr.

Julgamento:

Prof. Dr.

Julgamento:

Prof. Dr.

Julgamento:

Prof. Dr.

Julgamento:
Instituição:

Assinatura:

Instituição:

Assinatura:

Instituição:

Assinatura:

Instituição:

Assinatura:

Instituição:

Assinatura: 


\section{Dedicatória}

\section{A Minha Família}

Aos meus pais, que são meus exemplos de dedicação e trabalho e que sempre me deram o amor, apoio e incentivo para seguir os objetivos traçados em minha vida profissional

A minha vó Carmen pelo carinho

As minhas irmãs Simone e Sandra pelo amor incondicional

Aos meus sobrinhos, Victor, Gustavo, Leonardo Nataly e Matheus, que esse trabalho possa servir de exemplo para que eles sempre busquem o conhecimento para crescerem e que saibam que sempre poderão contar com seu tio Huber 


\section{AGRADECIMENTOS}

À Prof ${ }^{a}$. Dra ${ }^{a}$. Lilian Gregory, pelos até aqui nove anos de convivência, trabalho, paciência e amizade que sempre acrescentaram em minha formação e principalmente pelas oportunidades proporcionadas que enriqueceram tanto minha vida profissional quanto pessoal.

Aos colegas de equipe orientados pela Prof ${ }^{a}$. Dr ${ }^{\underline{a}}$. Lilian Gregory: Marjore, Laura, Alessandra, pela convivência harmônica e Enoch, Fernanda e Eduardo por também auxiliarem nas colheitas e processamento das amostras.

As pesquisadoras Eliana Scarcelli, Lília Paulin e Vanessa Castro e pós graduandas Aline Feola e Rosana Lisboa Santana do Laboratório de Doenças Bacterianas da Reprodução e as pesquisadoras do Laboratório de Raiva e Encefalites Virais, Eliana Villalobos, Maria do Carmo e Elenice Cunha e a funcionária Márcia, todas do Instituto Biológico de São Paulo que foram de fundamental importância para a realização do diagnóstico das amostras.

Ao professor Silvio Arruda que disponibilizou o Laboratório de Zoonoses Bacterianas da FMVZ-USP e a funcionária Zenáide Maria de Moraes, pelo processamento das amostras para diagnóstico de Leptospirose.

Ao meu primo Fidel que foi imprescindível na realização das análises estatísticas.

A todos os proprietários de criatórios ovinos do estado de São Paulo que proporcionaram o desenvolvimento confiando nessa pesquisa abrindo as portas para que as amostras fossem colhidas e aos funcionários que dispensaram parte de seu tempo para auxiliar na colheita das amostras.

Aos médicos veterinários Luiz Mertens, Rafael, Guizela e Guilherme que auxiliaram na identificação de ovinos com histórico de problemas reprodutivos para a colheita das amostras. 
Aos residentes e estagiários do Hospital de Ruminantes da FMVZ-USP dos anos de 2007, 2008, 2009 e 2010 que foram sempre prestativos em auxiliar nas colheitas das amostras.

Aos pesquisadores franceses do INRA de Tours Gerard Baril, Bernard Leboeuf, Juliette Cognié, Alice Fatet, Florence Guignot, Jean Paul Petit, Lippe, Pascal Mermillod e outros não citados, pelos conhecimentos compartilhados e amizade.

Aos funcionários da biblioteca da FMVZ-USP pela gentileza e Elza Faquim pela revisão dessa tese.

Aos professores do departamento de clínica médica da FMVZ-USP: Fernando José Benesi, Eduardo Birgel Júnior, Alice Maria Meilville Paiva Della Libera, Enrico Lippi Ortolani, Maria Claudia Araripe Sucupira, Wanderley Pereira Araújo (in memoriam), Viviane Gomes, Fabio Celidonio Pogliani, Wilson Roberto Fernandes e Carlos Eduardo Larsson.

Aos amigos de pós-graduação: Frederico, João Paulo, Karina, Tio Chico, Bruno, Humberto, Carol, Rebeca, Fernanda, Raquel, Bruna, Maiara, Camila, Mariana, Eliza e Elizabeth Boland.

Aos funcionários do Hospital de Ruminantes da FMVZ-USP: Luizinho, Francisco e Édison pela amizade e convivência harmoniosa durante a realização desse trabalho

A secretaria de pós graduação Adelaide Borges e secretárias do departamento; Cida e Silvana por toda atenção e solicitude.

A Faculdade de Medicina Veterinária e Zootecnia da USP e Instituto Biológico de São Paulo que possibilitaram a execução desta pesquisa e pela minha formação. 
A Fundação de Amparo a Pesquisa do Estado de São Paulo - FAPESP, pela concessão de bolsa de doutorado e auxilio a pesquisa.

A Universidade de Santo Amaro e Prof. Dr. Antonio Fernandes Filho que me proporcionaram os conhecimentos durante a graduação.

A todos que de alguma forma contribuíram para a execução deste trabalho

A todos ovinos que foram utilizados nesse estudo que serviram de fonte de aprendizado para realização dessa tese. 


\section{RESUMO}

RIZZO, H. Estudo da ocorrência e avaliação clínica das principais enfermidades do trato genital de ovinos (Ovis aries, Linnaeus, 1758) criados no estado de São Paulo. [Ocurrence and clinical evaluation of sheep genital diseases (Ovis aries, Linnaeus, 1758) established on the state of São Paulo]. 2011. $217 \mathrm{f}$. Tese (Doutorado em Ciências) - Faculdade de Medicina Veterinária e Zootecnia, Universidade de São Paulo, São Paulo, 2011.

A ovinocultura é um sistema de criação muito antigo em nosso país e ainda continua apresentando uma série de problemas que dificultam a produção econômica desses animais e necessitam de urgentes soluções. Visando minorar estes prejuízos esta pesquisa foi idealizada com o intuito de realizar um estudo minuncioso das principais enfermidades reprodutivas parasitárias e bacterianas. Todos os animais foram submetidos ao exame clínico geral e específico do sistema reprodutor e colheram-se amostras de soro, sêmen, abortamentos, lóquios, secreções, fezes e zaragatoa prepucial e vaginal dependendo da enfermidade a ser estudada. Não foi possível o isolamento nos fetos de nenhum agente etiológico. Conclui-se que a toxoplasmose é a enfermidade de maior importância nos rebanhos de estado de São Paulo e a de maior fator de risco em casos de abortamentos, a neosporose estaria relacionada principalmente com animais que apresentam repetição de cio, leptospirose foi observado em baixa titulação e a mais prevalente foi a Leptospira australis sorovar australis proveniente de animais silvestres, a campilobacteriose e a brucelose são as duas enfermidades da reprodução com menor ocorrência no estado. Foi isolado o primeiro caso de endometrite no Brasil por Histophilus somni. Foi isolado o primeiro caso de orquite por Actinobacillus seminis no estado de São Paulo.

Palavras-chave: Ovino. Brucella ovis. Campilobacteriosec Leptospirose. Neosporose. Toxoplasmose. 


\begin{abstract}
$\mathrm{RIZZO}, \mathrm{H}$. Ocurrence and clinical evaluation of sheep genital diseases (Ovis aries, Linnaeus, 1758) established on the state of São Paulo. [Estudo da ocorrência e avaliação clínica de enfermidades do trato genital de ovinos (Ovis aries, Linnaeus, 1758) criados no estado de São Paulo] 2011. 217 f. Tese (Doutorado em Ciências) - Faculdade de Medicina Veterinária e Zootecnia, Universidade de São Paulo, São Paulo, 2011.

Sheep industry is a traditional system in Brazil and presents a series of issues that complicate economical exploitation and urgently need solution. In order to reduce losses this research was idealized to carefully study the major bacterial and parasitary reproductive diseases. All animals were submitted to a general and specific reproductive system clinical examination. Blood, semen, abortions, lochia, vaginal discharges, feces, and preputial/vaginal swabs were collected according to the studied disease. It was not possible to isolate any etiological agent from aborted fetuses. The conclusion was that toxoplasmosis was the major disease on São Paulo herds and has the biggest risk factor in abortions, neosporosis would be related to animals that present heat repetition, leptospirosis was observed with low antibodies titles and the most prevalent was Leptospira australis sorovar australis arising from wild animals, campilobacteriosis and brucellosis are both the reproductive diseases with the lowest occurrence in the state. The first endometritis case caused by Histophilus somni. In Brazil was isolated. The first orchitis case caused by Actinobacillus seminis in São Paulo state was isolated.
\end{abstract}

Keywords: Ovine. Brucella ovis. Campylobacteriosis. Leptospirosis. Neosporosis. Toxoplasmosis. 


\section{LISTA DE QUADROS}

Quadro 1 - Ficha de colheita de dados do criatório ovino, São Paulo 2011.... 81

Quadro 2 - Ficha ginecológica de exame clínico do trato reprodutivo de fêmea ovina, São Paulo 2011................................................ 82

Quadro 3 - Ficha de exame clínico do trato reprodutivo de macho ovino, São

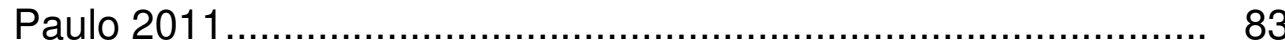




\section{LISTA DE TABELAS}

Tabela 1 - Freqüência de ovinos submetidos à colheita de material que pertenciam a criatórios do estado de São Paulo com sistema de criação intensivo ou semi-intensivo, São Paulo 2011.

Tabela 2 - Freqüência de ovinos submetidos à colheita de material que pertenciam a criatórios do estado de São Paulo com ou sem estabulação, São Paulo 2011

Tabela 3 - Freqüência de ovinos submetidos à colheita de material e o tipo de alimentação fornecida nos criatórios do estado de São Paulo, São Paulo 2011

Tabela 4 - Freqüência de ovinos submetidos à colheita de material pertencente a criatórios do estado de São Paulo onde havia a presença de espécies animais que podem agir como transmissores das enfermidades estudadas, São Paulo 2011..... 98

Tabela 5 - Freqüência de ovinos submetidos à colheita de material pertencente a criatórios do estado de São Paulo onde se aplicava exclusivamente monta natural ou mista (monta natural e I.A. e/ou T.E), São Paulo 2011

Tabela 6 - Freqüência da raça e sexo dos ovinos submetidos à colheita de material para análise diagnóstica, São Paulo, 2011

Tabela 7 - Freqüência de alterações quanto ao tamanho da vulva em animais submetidos ao exame clínico ginecológico, São Paulo, 2011

Tabela 8 - Freqüência de alterações vulvares em animais submetidos ao exame clínico ginecológico, São Paulo, 2011...

Tabela 9 - Freqüência de alterações vaginais observadas durante a inspeção indireta, São Paulo 2011.

Tabela 10 - Freqüência de secreções patológicas e fisiológicas observadas em 66 fêmeas que apresentaram secreção uterina no momento do exame ginecológico, São Paulo, 2011. 
Tabela 11 - Freqüência de alterações clínicas no histórico reprodutivo ou observadas no momento da colheita de material para diagnóstico de fêmeas ovinas submetidas ao exame ginecológico, São Paulo, 2011

Tabela 12 - Freqüência do período de gestação que ocorreram abortamentos, São Paulo, 2011.

Tabela 13 - Freqüência de alterações clínicas no histórico reprodutivo ou observadas no momento da colheita de material para diagnóstico de machos ovinos, São Paulo, 2011

Tabela 14 - Freqüência de alterações clínicas em testículos e epidídimos de ovinos submetidos à inspeção e palpação do trato reprodutivo, São Paulo, 2011

Tabela 15 - Freqüência sorológica de Brucella ovis diagnosticada pela prova de fixação de complemento em 294 soros de ovinos com histórico de problemas reprodutivos, São Paulo, 2011

Tabela 16 - Freqüência de titulação em unidades internacionais (U.I.) de soros ovinos positivos para Brucella ovis pela prova de fixação de complemento, São Paulo, 2011

Tabela 17 - Freqüência de ovinos sororeagentes a Leptospirose pela prova de soroaglutinação microscópica em 294 soros de animais com histórico de problemas reprodutivos, São Paulo, $2011 .$.

Tabela 18 - Freqüência e distribuição de 87 reações de soroaglutinização com 15 sorovares diferentes na prova de soroaglutinação microscópica em 294 soros ovinos, São Paulo, 2011

Tabela 19 - Freqüência de ovinos reagentes a Neospora caninum pela prova de imunofluorescência indireta com diluição de 1:50 em 294 soros de animais com histórico de problemas reprodutivos, São Paulo, 2011.

Tabela 20 - Freqüência de ovinos reagentes a Toxoplasma gondii pela prova de imunofluorescência indireta com diluição de 1:64 em 294 soros de animais com histórico de problemas reprodutivos, São Paulo, 2011

Tabela 21 - Freqüência de isolados de Campylobacter spp. em 274 amostras 
fecais ovinas, São Paulo, 2011

Tabela 22 - Freqüência de espécies de Campylobacterspp. nas 10 amostras fecais ovinas onde foi realizado isolamento, São Paulo, 2011......

Tabela 23 - Distribuição das amostras de soro e fezes submetidas ao diagnóstico sorológico para Brucella ovis, Leptospirose, Toxoplasma gondii e Neospora caninum e bacteriológico para Campylobacter spp., demonstrando ocorrência de amostras sororeagentes a uma ou mais das enfermidades estudadas ou ainda a nenhuma delas, São Paulo, 2011

Tabela 24 - Relação de bactérias isoladas em amostras de fetos, órgãos, sêmen, secreção uterina, secundinas, zaragatoa prepucial e vaginal fruto de contaminação bacteriana no momento da colheita, São Paulo, 2011.

Tabela 25 - Freqüência de ovinos pertencentes a criatórios do estado de São Paulo positivos para as enfermidades estudadas em relação aos sistemas de criação intensivo ou semi-intensivo, São Paulo 2011.

Tabela 26 - Freqüência de ovinos pertencentes a criatórios do estado de São Paulo positivos para as enfermidades estudadas em relação à presença ou não de estabulação, São Paulo 2011

Tabela 27 - Freqüência de ovinos pertencentes a criatórios do estado de São Paulo positivos para as enfermidades estudadas em relação ao tipo de alimentação fornecida, São Paulo 2011.

Tabela 28 - Freqüência de ovinos pertencentes a criatórios do estado de São Paulo positivos para as enfermidades estudadas em relação à presença de outras espécies animais no criatório, São Paulo 2011.

Tabela 29 - Freqüência de ovinos pertencentes a criatórios do estado de São Paulo positivos para as enfermidades estudadas em relação ao tipo de cobertura, natural ou mista (I.A. e/ou T.E), São Paulo 2011.

Tabela 30 - Tabela 30. Relação entre animais sororeagentes para Brucella ovis, Leptospirose, Toxoplasma gondii e Neospora caninum e 
com isolamento de Campylobacter spp. que apresentavam sinais clínicos, em relação ao total de sinais clínicos observados no momento do exame ginecológico de ovinos, São Paulo, 2011. 124

Tabela 31 - Relação entre animais sororeagentes para Brucella ovis, Leptospirose, Toxoplasma gondii e Neospora caninum e com isolamento de Campylobacter spp. que apresentavam histórico de problemas reprodutivos, em relação ao total de problemas no histórico reprodutivo de fêmeas ovinas, São Paulo, 2011.

Tabela 32 - Análise de significância (valor de p) entre animais sororeagentes a Brucella ovis em relação ao sexo, raça, tipo de instalação, alimentação, sistema de criação, presença de outras espécies animais e tipo de monta, São Paulo, 2011.

Tabela 33 - Análise de significância (valor de $p$ ) entre animais sororeagentes a Brucella ovis em relação à presença ou não de sinais clínicos no momento do exame ginecológico, São Paulo, 2011

Tabela 34 - Análise de significância (valor de p) entre animais sororeagentes a Brucella ovis em relação à presença ou não de distúrbios reprodutivos no histórico de fêmeas ovinas, São Paulo, 2011.......

Tabela 35 - Análise de significância (valor de p) entre animais sororeagentes a Leptospirose em relação ao sexo, raça, tipo de instalação, alimentação, sistema de criação, presença de outras espécies animais e tipo de monta, São Paulo, 2011

Tabela 36 - Fator de risco entre a infecção por Leptospiras e a presença de felídeos em criatórios ovinos do estado de São Paulo, São Paulo, 2011

Tabela 37 - Análise de significância (valor de p) entre animais sororeagentes a Leptospiras em relação à presença ou não sinais clínicos no momento do exame ginecológico, São Paulo, 2011

Tabela 38 - Fator de risco entre infecção por Leptospiras e a presença de telangectasia da mucosa vaginal de ovinos criados no estado de São Paulo, São Paulo, 2011

Tabela 39 - Análise de significância (valor de $p$ ) entre animais sororeagentes a Leptospirose em relação à presença ou não de distúrbios 
reprodutivos no histórico de fêmeas ovinas, São Paulo, 2011

Tabela 40 - Fator de risco entre infecção por Leptospiras e a ocorrência de abortamentos em ovinos criados no estado de São Paulo, São Paulo, 2011

Tabela 41 - Fator de risco entre infecção por Leptospiras e a presença de endometrite em ovinos criados no estado de São Paulo, São Paulo, 2011.

Tabela 42 - Análise de significância (valor de p) entre animais sororeagentes a Neospora caninum em relação ao sexo, raça, tipo de instalação, alimentação, sistema de criação, presença de outras espécies animais e tipo de monta, São Paulo, 2011

Tabela 43 - Fator de risco entre infecção por Neospora caninum e o sexo de ovinos de criatórios do estado de São Paulo, São Paulo, 2011.....

Tabela 44 - Fator de risco entre infecção por Neospora caninum e a raça de ovinos de criatórios do estado de São Paulo, São Paulo, 2011.... 134

Tabela 45 - Fator de risco entre infecção por Neospora caninum e a presença ou não de estábulos em criatórios ovinos do estado de São Paulo, São Paulo, 2011

Tabela 46 - Fator de risco entre infecção por Neospora caninum e o tipo de alimentação fornecida em criatórios ovinos do estado de São Paulo, São Paulo, 2011

Tabela 47 - Fator de risco entre infecção por Neospora caninum e o sistema de criação de criatórios ovinos do estado de São Paulo, São Paulo, 2011

Tabela 48 - Análise de significância (valor de p) entre animais sororeagentes a Neospora caninum em relação à presença ou não de sinais clínicos no momento do exame ginecológico, São Paulo, 2011.... 136

Tabela 49 - Fator de risco entre infecção por Neospora caninum e a presença de secreção uterina em ovinos criados no estado de São Paulo, São Paulo, 2011

Tabela 50 - Análise de significância (valor de p) entre animais sororeagentes a Neospora caninum em relação à presença ou não de distúrbios reprodutivos no histórico de fêmeas ovinas, São 
Paulo, 2011.

Tabela 51 - Fator de risco entre infecção por Neospora caninum e a ocorrência de abortamentos em ovinos criados no estado de São Paulo, São Paulo, 2011

Tabela 52 - Fator de risco entre infecção por Neospora caninum e a ocorrência de repetição de cio em ovinos criados no estado de São Paulo, São Paulo, 2011.

Tabela 53 - Análise de significância (valor de p) entre animais sororeagentes a Toxoplasma gondii em relação ao sexo, raça, tipo de instalação, alimentação, sistema de criação, presença de outras espécies animais e tipo de monta, São Paulo, 2011

Tabela 54 - Fator de risco entre infecção por Toxoplasma gondii e a raça de ovinos de criatórios do estado de São Paulo, São Paulo, 2011.....

Tabela 55 - Fator de risco entre infecção por Toxoplasma gondii e a raça de ovinos de criatórios do estado de São Paulo, utilizando ovinos de raças lanadas como referência, São Paulo, 2011

Tabela 56 - Fator de risco entre infecção por Toxoplasma gondii e a presença ou não de estábulos em criatórios ovinos do estado de São Paulo, São Paulo, 2011

Tabela 57 - Fator de risco entre infecção por Toxoplasma gondii e tipo de alimentação fornecida em criatórios ovinos do estado de São Paulo, São Paulo, 2011

Tabela 58 - Fator de risco entre infecção por Toxoplasma gondii e tipo de alimentação fornecida em criatórios ovinos do estado de São Paulo, utilizando a categoria tipo de alimentação, Pastagem + Concentrado + Silagem como referência, São Paulo, 2011

Tabela 59 - Fator de risco entre infecção por Toxoplasma gondii e a presença de felídeos e aves em criatórios ovinos do estado de São Paulo, São Paulo, 2011

Tabela 60 - Análise de significância (valor de p) entre animais reagentes a Toxoplasma gondii em relação à ausência de felídeos em criatórios de ovinos do estado de São Paulo, São Paulo, 2011.... 142

Tabela 61 - Fator de risco entre infecção por Toxoplasma gondii e a 
ausência de felídeos em criatórios ovinos do estado de São Paulo, São Paulo, 2011

Tabela 62 - Fator de risco entre infecção por Toxoplasma gondii e o sistema de reprodução utilizado em criatórios ovinos do estado de São Paulo, São Paulo, 2011

Tabela 63 - Análise de significância (valor de p) entre animais reagentes a Toxoplasma gondii em relação à presença ou não de sinais clínicos no momento do exame ginecológico, São Paulo, 2011.... 142

Tabela 64 - Análise de significância (valor de p) entre animais reagentes a Toxoplasma gondii em relação à presença ou não de distúrbios reprodutivos no histórico de fêmeas ovinas, São Paulo, 2011.......

Tabela 65 - Fator de risco entre infecção por Toxoplasma gondii e a ocorrência de abortamentos em ovinos criados no estado de São Paulo, São Paulo, 2011

Tabela 66 - Fator de risco entre infecção por Toxoplasma gondii e a ocorrência de repetição de cio em ovinos criados no estado de São Paulo, São Paulo, 2011

Tabela 67 - Análise de significância (valor de p) entre ovinos com isolamento de Campylobacter spp. em amostras fecais em relação ao sexo, raça, tipo de instalação, alimentação, sistema de criação, presença de outras espécies animais e tipo de monta, São Paulo, 2011.

Tabela 68 - Análise de significância (valor de p) entre ovinos com isolamento de Campylobacter spp. em amostras fecais em relação à presença ou não sinais clínicos no momento do exame ginecológico, São Paulo, 2011.

Tabela 69 - Fator de risco entre ovinos com isolamento de Campylobacter spp. em amostras fecais e a presença de petéquias na mucosa vaginal de ovinos criados no estado de São Paulo, São Paulo, 2011

Tabela 70 - Análise de significância (valor de p) entre ovinos com isolamento de Campylobacter spp. em amostras fecais em relação à presença ou não de distúrbios reprodutivos no histórico de 
fêmeas ovinas, São Paulo, 2011

Tabela 71 - Fator de risco entre ovinos com isolamento de Campylobacter spp. em amostras fecais e ocorrência de morte neonatal criatórios do estado de São Paulo, São Paulo, 2011.

Tabela 72 - Fator de risco entre ovinos com isolamento de Campylobacter spp. em amostras fecais e ocorrência de nascimento de cordeiro "fraco" em criatórios do estado de São Paulo, São Paulo, 2011... 148

Tabela 73 - Fator de risco entre ovinos com isolamento de Campylobacter spp. em amostras fecais e ocorrência retenção de placenta em animais de criatórios do estado de São Paulo, São Paulo, 2011... 148

Tabela 74 - Análise de significância (valor de p) entre ovinos com isolamento de Campylobacter spp. em amostras fecais em relação à ocorrência de diarréia em animais de criatórios do estado de São Paulo, São Paulo, 2011

Tabela 75 - Fator de risco entre ovinos com isolamento de Campylobacter spp. em amostras fecais e ocorrência de diarréia em animais de criatórios do estado de São Paulo, São Paulo, 2011.

Tabela 76 - Fator de risco de ovinos infectados por Brucella ovis, Campylobacter spp., Leptospiras, Neospora caninum ou Toxoplasma gondii em criatórios ovinos do estado de São Paulo que possuem estábulos, São Paulo 2011

Tabela 77 - Fator de risco de ovinos infectados por Brucella ovis, Campylobacter spp., Leptospiras, Neospora caninum ou Toxoplasma gondii em criatórios ovinos do estado de São Paulo de acordo com o tipo de alimentação fornecida, São Paulo 2011. 150

Tabela 78 - Fator de risco de ovinos infectados por Brucella ovis, Campylobacter spp., Leptospiras, Neospora caninum ou Toxoplasma gondii em criatórios ovinos do estado de São Paulo em relação à utilização do sistema semi-intensivo de criação, São Paulo 2011

Tabela 79 - Fator de risco de ovinos infectados por Brucella ovis, Campylobacter spp., Leptospiras, Neospora caninum ou Toxoplasma gondii em criatórios ovinos do estado de São Paulo 
que utilizam exclusivamente cobertura de fêmeas através de monta natural, São Paulo 2011

Tabela 80 - Fator de risco de ovinos infectados por Brucella ovis, Campylobacter spp., Leptospiras, Neospora caninum ou Toxoplasma gondii em criatórios ovinos do estado de São Paulo onde havia a presença de felídeos, São Paulo 2011.

Tabela 81 - Fator de risco de ovinos infectados por Brucella ovis, Campylobacter spp., Leptospiras, Neospora caninum ou Toxoplasma gondii em criatórios ovinos do estado de São Paulo onde havia a presença de aves, São Paulo 2011

Tabela 82 - Fator de risco de ovinos infectados por Brucella ovis, Campylobacter spp., Leptospiras, Neospora caninum ou Toxoplasma gondii em criatórios ovinos do estado de São Paulo de apresentarem petéquias na mucosa vaginal, São Paulo 2011. 152

Tabela 83 - Fator de risco de ovinos infectados por Brucella ovis, Campylobacter spp., Leptospiras, Neospora caninum ou Toxoplasma gondii em criatórios ovinos do estado de São Paulo de apresentarem quadros de abortamentos, São Paulo 2011.......

Tabela 84 - Fator de risco de ovinos infectados por Brucella ovis, Campylobacter spp., Leptospiras, Neospora caninum ou Toxoplasma gondii em criatórios ovinos do estado de São Paulo de apresentarem quadros de endometrite, São Paulo 2011.

Tabela 85 - Fator de risco de ovinos infectados por Brucella ovis, Campylobacter spp., Leptospiras, Neospora caninum ou Toxoplasma gondii em criatórios ovinos do estado de São Paulo de apresentarem quadros de morte neonatal, São Paulo 2011.....

Tabela 86 - Tabela 86: Fator de risco de ovinos infectados por Brucella ovis, Campylobacter spp., Leptospiras, Neospora caninum ou Toxoplasma gondii em criatórios ovinos do estado de São Paulo de apresentarem quadros de nascimento de cordeiros "fracos", São Paulo 2011

Tabela 87 - Fator de risco de ovinos infectados por Brucella ovis, Campylobacter spp., Leptospiras, Neospora caninum ou 
Toxoplasma gondii em criatórios ovinos do estado de São Paulo de apresentarem quadros de distocia, São Paulo 2011

Tabela 88 - Fator de risco de ovinos infectados por Brucella ovis, Campylobacter spp., Leptospiras, Neospora caninum ou Toxoplasma gondii em criatórios ovinos do estado de São Paulo de apresentarem quadros de retenção de placenta, São Paulo 2011

Tabela 89 - Fator de risco de ovinos infectados por Brucella ovis, Campylobacter spp., Leptospiras, Neospora caninum ou Toxoplasma gondii em criatórios ovinos do estado de São Paulo de apresentarem quadros de repetição de cio, São Paulo 2011... 


\section{LISTA DE FIGURAS}

Figura 1 - Colheita de amostra de secreção vaginal mucosa com utilização de tubo estéril para realização de isolamento bacteriano, São Paulo 2011

Figura 2 - Mucosa vaginal hiperêmica de ovino, observado no momento do exame ginecológico com a utilização de espéculo, São Paulo, 2011.

Figura 3 - Secreção uterina mucopurulenta de ovino da raça Texel, São Paulo, 2011

Figura 4 - Grande quantidade de secreção uterina mucopurulenta de ovino da raça Santa Inês, São Paulo 2011

Figura 5 - Secreção uterina purulenta de ovino da raça Santa Inês, São Paulo, 2011

Figura 6 - Lóquio eliminado por ovino da raça Santa Inês, pós abortamento, São Paulo, 2011

Figura 7 - Secreção uterina sanguinolenta de ovino da raça Santa Inês, São Paulo, 2011

Figura 8 - Secreção mucopurulenta aderida ao espéculo vaginal após exame ginecológico de ovino com histórico de abortamento, São Paulo, 2011.

Figura 9 - Feto ovino da raça Santa Inês abortado no terço inicial de gestação, São Paulo, 2011

Figura 10 - Produtos de abortamento de gestação dupla de ovino da raça Santa Inês em terço inicial de gestação, sendo o menor feto de aspecto mumificado, São Paulo, 2011

Figura 11 - Feto ovino da raça Santa Inês abortado em final de gestação, São Paulo, 2011

Figura 12 - Feto ovino da raça Santa Inês abortado em terço final de gestação, São Paulo, 2011.

Figura 13 - Feto ovino da raça Dorper, proveniente de transferência de embriões, abortado em terço final de gestação, São Paulo, 
Figura 14 - Feto ovino da raça Dorper, proveniente de transferência de embriões, abortado em terço final de gestação, São Paulo, 2011... 104

Figura 15 - Aumento de volume da região da cabeça do epidídimo direito, São Paulo, 2011

Figura 16 - Testículos de ovino da raça Texel positivo a Brucella ovis em duas prova sorológicas por fixação de complemento, sem presença de lesões testiculares palpáveis, São Paulo, 2001

Figura 17 - Testículos de ovino da raça Texel positivo a Brucella ovis em duas prova sorológicas por fixação de complemento, sem alterações macroscópicas ao exame macroscópico post morten, São Paulo, 2011

Figura 18 - Colheita de conteúdo gástrico de feto ovino abortado para realização de isolamento bacteriológico, São Paulo, 2011.

Figura 19 - Pool de órgãos de feto ovino abortado para realização de isolamento bacteriológico, São Paulo, 2011

Figura 20 - Colheita post morten, através de punção epididimal, de sêmen ovino da raça Texel positivo sorologicamente a Brucella ovis, para realização de isolamento bacteriológico, São Paulo 2011

Figura 21 - Baia de aprisco de ovino da raça Santa Inês com isolamento positivo de Campylobacter jejuni, apresentando contaminação de fezes de aves, São Paulo, 2011

Figura 22 - Cocho de ovino da raça Santa Inês com isolamento positivo de Campylobacter jejuni, apresentando contaminação de fezes de aves, São Paulo, 2011 


\section{LISTA DE GRÁFICOS}

Gráfico 1 - Freqüência de ovinos sororeagentes a Brucella ovis, Leptospirose, 112 Neosporose e Toxoplasmose e de isolamentos fecais de Campylobacter spp., divididos por sexo, São Paulo, 2011

Gráfico 2 - Distribuição das 5 amostras de soros ovino reagentes a Brucella ovis pela prova de fixação de complemento em relação ao diagnóstico sorológico para Leptospirose, Toxoplasmose, Neosporose e isolamento bacteriano de Campylobacter spp. positivo concomitantemente, São Paulo, 2011

Gráfico 3 - Distribuição das 67 amostras de soros ovino reagentes a Leptospirose pela prova de soroaglutinação microscópica em relação à reação para Brucella ovis, Toxoplasma gondii e Neospora caninum e isolamento para Campylobacter spp. positivo concomitantemente, São Paulo, 2011

Gráfico 4 - Distribuição de 53 amostras de soros ovino reagentes a Neospora caninum pela prova imunofluorecência indireta em relação à reação para Brucella ovis, Leptospirose e Toxoplasma gondii e isolamento para Campylobacter spp. positivo concomitantemente, São Paulo, 2011

Gráfico 5 - Distribuição das 88 amostras de soros ovino reagentes a Toxoplasma gondii pela prova imunofluorecência indireta em relação à reação para Brucella ovis, Leptospirose e Neospora caninum e isolamento para Campylobacter spp. positivo concomitantemente, São Paulo, 2011

Gráfico 6 - Distribuição das 10 amostras de fezes ovina onde foi realizado isolamento de Campylobacter spp. em relação à sororeação a Brucella ovis, Leptospirose e Toxoplasma gondii concomitantemente, São Paulo, 2011 


\section{LISTA DE ABREVIATURAS}

\begin{tabular}{|c|c|}
\hline$\stackrel{\circ}{ } \mathrm{C}$ & Celsius \\
\hline$\mu \mathrm{L}$ & Microlitro \\
\hline $\mathrm{ml}$ & Mililitro \\
\hline L & Litro \\
\hline $\mathrm{Mm}$ & Micrometro \\
\hline$\mu \mathrm{m}$ & Milímetro \\
\hline $\mathrm{cm}$ & Centímetro \\
\hline $\mathrm{cm}^{2}$ & Centímetro quadrado \\
\hline $\mathrm{V} / \mathrm{cm}$ & Watts/centímetro \\
\hline$\mu g$ & Micrograma \\
\hline $\mathrm{mg}$ & Miligrama \\
\hline$g$ & Gramas \\
\hline $\mathrm{Kg}$ & Kilograma \\
\hline pmol & Picomol \\
\hline $\mathrm{mM}$ & Milimol \\
\hline M & Molar \\
\hline s & Segundos \\
\hline $\mathrm{CO}_{2}$ & Gás carbônico \\
\hline $\mathrm{Kb}$ & Kilobyte \\
\hline $\mathrm{pb}$ & Pares de bases \\
\hline $\mathrm{Kpb}$ & Kilo pares de base \\
\hline $\mathrm{HCl}$ & Ácido clorídrico \\
\hline $\mathrm{KCl}$ & Cloreto de potássio \\
\hline $\mathrm{NaOH}$ & Hidróxido de sódio \\
\hline $\mathrm{NaCl}$ & Cloreto de sódio \\
\hline $\mathrm{F}$ & Fêmeas ovinas \\
\hline M & Machos ovinos \\
\hline $\mathrm{n}$ & Número de amostras \\
\hline № & Número \\
\hline$p$ & Nível de significância \\
\hline DNA & Ácido desoxirribonucléicc \\
\hline
\end{tabular}


EDTA

E.U.A.

ha

I.A.

I.M.

$\lg G$

$\lg \mathrm{M}$

Nasc.

OPG

OR

PBS

PCR

rpm

Ref.

RIFI

Sist.

T.E.

UI

URSS
Ácido etilenodiaminotetracético

Estados Unidos da América

Hectare

Inseminação Artificial

Intramuscular

Imunoglobulina G

Imunoglobulina M

Nascimento

Ovos por gramas

Odds ratio

Phosphated buffer saline

Polimerase chain reaction

Rotação por minuto

Referência

Reação de Imunofluorescência

Sistema

Transferência de Embriões

Unidade Internacional

União Soviética 


\section{LISTA DE SIMBOLOS}

$\begin{array}{cc}+ & \text { Mais } \\ - & \text { Menos } \\ \mathrm{X} & \text { Vezes } \\ = & \text { Igual } \\ \geq & \text { Maior ou igual } \\ < & \text { Menor } \\ \leq & \text { Menor ou igual } \\ \cong & \text { Aproximadamente } \\ \% & \text { Porcentagem } \\ + & \text { Mais }\end{array}$




\section{SUMÁRIO}

1 INTRODUÇÃO

2 REVISÃO DE LITERATURA .......................................................... 34

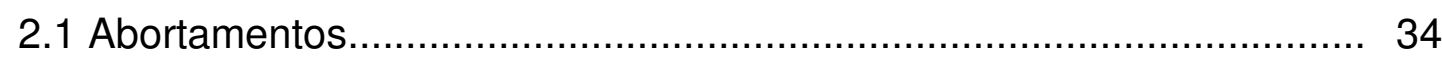

2.2 Infertilidade $x$ Nutrição................................................................ 38

2.3 Nascimento de cordeiros "fracos" e morte neonatal........................... 39

2.4 Agentes e fatores relacionados à queda de fertilidade nos carneiros... 40

2.5 Actinobacillus seminis............................................................. 41

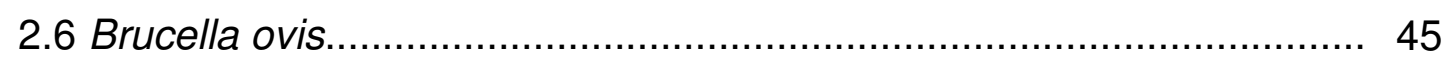

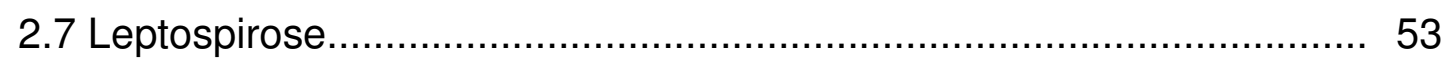

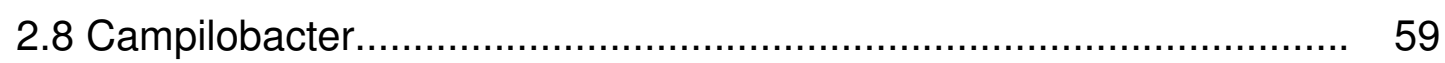

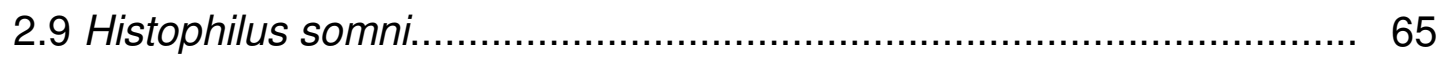

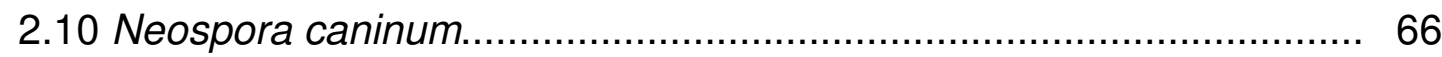

2.11 Toxoplasma gondii............................................................... 70

3 MATERIAL E MÉTODOS...................................................... 80

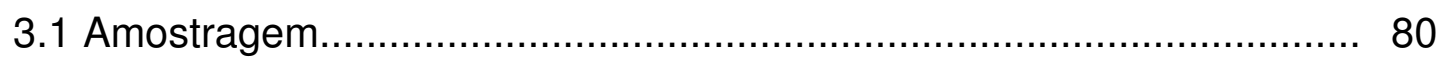

3.2 Colheita de dados............................................................... 80

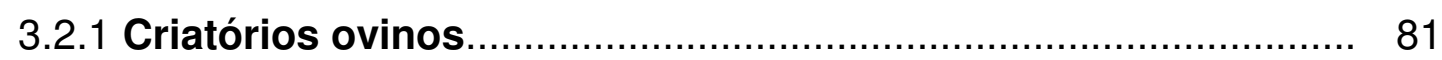

3.2.2 Avaliação clínica dos animais................................................ 81

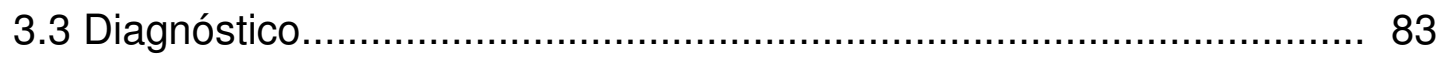

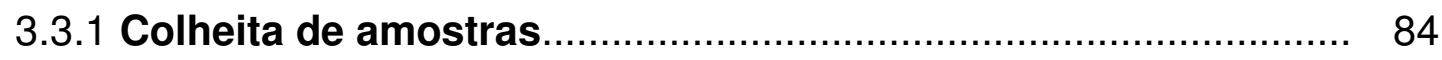

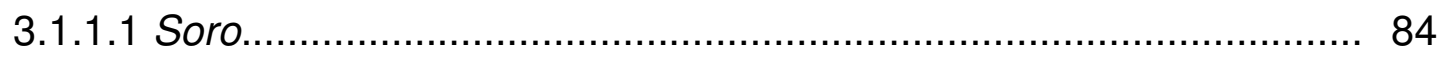

3.1.1.2 Fezes para isolamento de Campilobacter spp.............................. 85

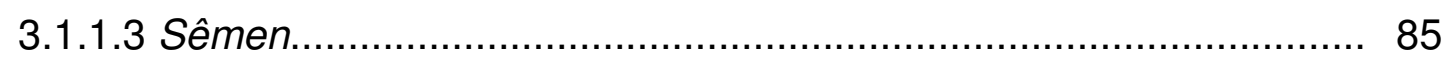

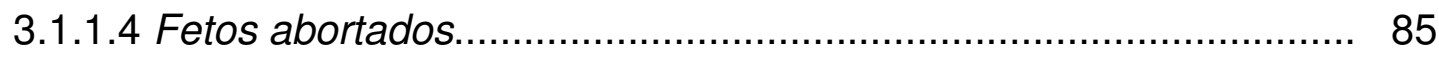

3.1.1.5 Secundinas e secreções uterinas............................................. 85

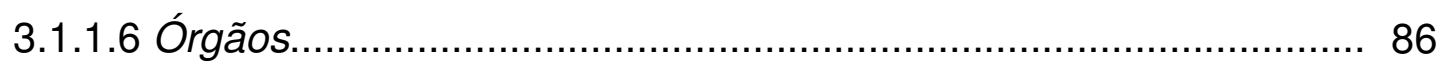

3.2 Diagnósticos sorológicos............................................................ 86

3.2.1 Teste de fixação do complemento (RFC-0) para Brucella ovis... 86

3.2.1.1 Antígeno para Brucella ovis..................................................... 87

3.2.1.2 Diluição e inativação dos soros................................................... 87 
3.2.2 Soroaglutinação microscópica para Leptospirose.

3.3 Doenças parasitárias

3.3.1Imunofluorescência indireta para Neospora caninum e Toxoplasma gondii.. 88

3.4 Diagnóstico microbiológico......................................................... 89

3.4.1 Pesquisa de Campylobacter spp. em amostras de fezes............ 89

3.4.2 Pesquisa de Campylobacter spp., Brucella spp. e Histophilus somni em amostras de fetos abortados, sêmen, secreção ou muco vaginal e prepucial.

3.4.3 Cultivo microbiológico de material clínico para Actinobacillus seminis.

3.4.4 Procedimento bacteriológico para isolamento e identificação de Brucella spp.

3.4.5 Diagnóstico microbiológico para Leptospira spp. 91

3.4.6Procedimentos bacteriológicos para isolamento e identificação Histophlilus somni. 91

3.5 Isolamento parasitário. 92

3.5.1 Preparo da amostra para isolamento de Neospora spp. e Toxoplasma gondii.. 92

3.5.2 Isolamento do Neospora spp. e Toxoplasma gondii. 93

3.6 Reação em cadeia da polimerase (PCR). 93

3.6.1 Detecção de DNA de Toxoplasma gondii em órgãos dos camundongos. 94

3.6.2 Extração do DNA de Toxoplasma gondii... 94

3.6.3 Ampliação do DNA de Toxoplasma gondii................................. 95

3.6.4 Análise do produto amplificado.................................................. 95

3.6.5 Ampliação do DNA de Neospora caninum e análise do produto amplificado.

3.6.6 Ampliação do DNA de Brucella spp, Leptospira spp., Chlamydophila sp e Listeria monocytogenes e análise do produto amplificado.

3.7Forma de análise dos resultados 96 
4.1 Freqüências das características analisadas dos criatórios ovinos do estado de São Paulo.

4.2 Freqüências das características dos animais estudados, dados do exame ginecológico, andrológico e do histórico reprodutivo.

4.3 Freqüências de ovinos sororeagentes a Brucella ovis em rebanhos do estado de São Paulo.

4.4 Freqüências de ovinos sororeagentes a Leptospirose em rebanhos estado de São Paulo.

4.5 Freqüências de ovinos reagentes a Neospora caninum em rebanhos do estado de São Paulo.

4.6 Freqüências de ovinos reagentes a Toxoplasma gondii em rebanhos do estado de São Paulo.

4.7 Freqüências de isolamentos de Campylobacter spp. em amostras fecais ovinas em rebanhos estado de São Paulo.

4.8 Freqüências de animais positivos a nenhuma, uma ou mais de uma das enfermidades estudadas.

4.9 Isolamentos de bactérias patogênicas............................................... 116

4.10 Contaminações bacteriana.......................................................... 119

4.11 Reação de cadeia de polimerase (PCR)....................................... 121

4.12 Freqüências das características analisadas dos criatórios ovinos do estado de São Paulo em relação a ovinos positivos as enfermidades estudadas.

4.13 Freqüências de sinais clínicos observados e dados do histórico reprodutivo em relação a ovinos positivos as enfermidades estudadas.

4.14 Significância $(p)$ e fator de risco entre os parâmetros analisados e as enfermidades estudadas

4.14.1 Brucella ovis. 126

4.14.2 Leptospirose 129

4.14.3 Neospora caninum. 132

4.14.4 Toxoplasma gondii.. 138

4.14.5 Campilobacter 144

4.15 Análise de fator de risco entre as enfermidades estudadas. 
5 DISCUSSÃO

5.1 Brucelose e Actinobacillus seminis.................................................. 155

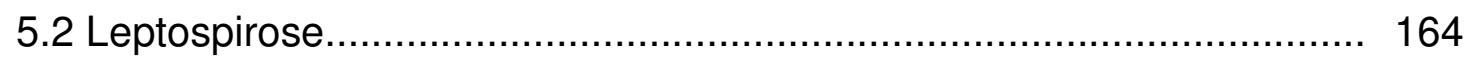

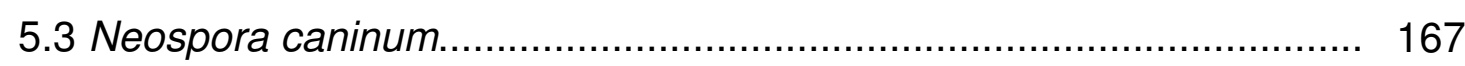

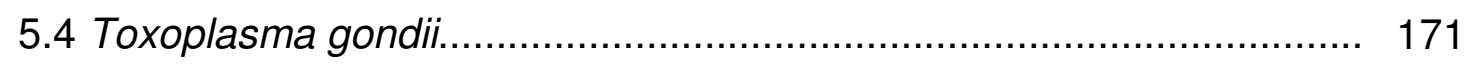

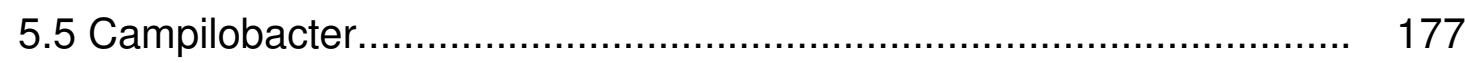

5.6 Histophilus somni.................................................................. 182

5.7Outros agentes etiológicos............................................................ 183

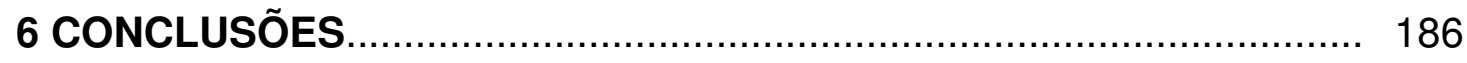

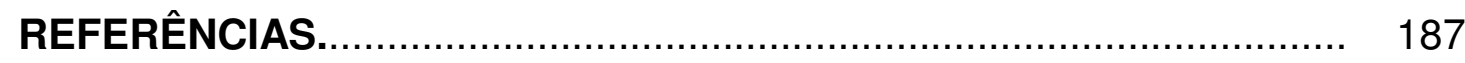




\section{INTRODUÇÃO}

A caprinocultura e a ovinocultura têm se destacado no agronegócio brasileiro. A criação de caprinos, com rebanho estimado em 14 milhões de animais, distribuído em 436 mil estabelecimentos agropecuários, colocou o Brasil em 18ํㅣ lugar do ranking mundial de exportações. A ovinocultura tem maior representatividade nos estados da Bahia, Ceará, Piauí e Pernambuco, Rio grande do Norte, Rio Grande do Sul, Paraná e Mato Grosso do Sul. Carne, pele e lã estão entre os principais produtos. A produção anual alcança 11 milhões de toneladas de lã, principalmente no Rio Grande do Sul, com cadeia produtiva formada por 35 mil estabelecimentos agropecuários. A ovinocultura leiteira no País apresenta potencial para a produção de queijos finos, muito valorizados no mercado. Caprinocultura e a ovinocultura vêm aumentando suas participações no agronegócio brasileiro e a tendência é de que se mantenham em expansão. Vários fatores nos cenários nacional e internacional mostram essa vertente. A mudança de atitude da população no que se refere à alimentação é um exemplo. Como a carne caprina é uma das mais magras, superando, inclusive, a de frango, tem conquistado mais adeptos. As estratégias de conquistas de novos mercados, também poderão impulsionar o consumo mundial desse tipo de carne. Para concretizar projeções e tendências são necessários investimentos em salubridade e inocuidade. Esse papel é exercido pelo Ministério da Agricultura, por meio do Programa Nacional de Sanidade dos Caprinos e Ovinos (PNSCO), que visa o fortalecimento da cadeia produtiva dessas espécies, pela adoção de ações de vigilância e defesa sanitária animal. A saúde do rebanho nacional é fundamental para garantir bom desempenho da cadeia produtiva e desenvolvimento da pecuária brasileira, além da importância para a preservação da saúde pública. Baseado nas legislações do Sistema Unificado de Atenção à Sanidade Agropecuária e da Organização Mundial de Saúde Animal (OIE), o Ministério da Agricultura elabora as diretrizes de ação governamental para a saúde animal e define requisitos sanitários e ações de combate às doenças. A saúde pecuária no Brasil conta com trabalho conjunto do governo federal, estadual e setor privado para a eficiência das ações de monitoração, prevenção e erradicação de doenças (PNSCO, 2004). 
Mesmo se tratando de um sistema de criação muito antigo em nosso país, a ovinocultura ainda apresenta uma série de problemas, que dificultam a produção econômica desses animais e necessitam de urgentes soluções, visando minorar os grandes prejuízos que causam a essa produção agropastoril. De fundamental importância dentre esses fatores, destacam-se as enfermidades infecto-contagiosas ainda muito comuns nos rebanhos brasileiros, associadas a outras, ainda consideradas como emergentes. Entre elas poderiam ser destacadas as verminoses, as broncopneumonias, as doenças dos recém-nascidos, a linfadenite caseosa e a micoplasmose. Além dessas enfermidades, atualmente, merece destaque as enfermidades reprodutivas, que podem retardar o desenvolvimento de um rebanho. 


\section{REVISÃO DE LITERATURA}

A seguir serão revisados brevemente os fatores e agentes etiológicos causadores de distúrbios reprodutivos que não foram abordados na tese, mas que possuem potencial semelhante aos relacionados com os agentes etiológicos do estudo.

\subsection{Abortamentos}

O abortamento é a perda do feto em qualquer fase da gestação e são eventos observados com freqüência em criações de ovinos variando de casos isolados a surtos. O aborto em um rebanho pode ser caracterizado como endêmico ou epidêmico. Na literatura mundial o aborto endêmico pode variar de $2 \%$ a $10 \%$ em um rebanho. Já o aborto epidêmico pode apresentar taxas superiores. A grande importância é que o aborto endêmico tende a ter ocorrência constante no rebanho, enquanto o aborto epidêmico tende a ocorrer de forma "explosiva", ou seja, em um curto espaço de tempo e com grande número de casos. Abortos são observados na maioria das criações, sendo que uma taxa de aborto entre 1,5 a $2 \%$ é considerada excelente e de até 5\% aceitável. Quando o índice eleve-se, devem ser tomadas providências necessárias para controle do quadro no rebanho (FIGUEIREDO; LAGE; HIRSCH, 2010).

Relatos de surtos datam do século XVII, em 1883 foi relatado em Lincolnshire, Inglaterra, surto de abortamento em $12 \%$ de 51.475 ovelhas, mais tarde entre 1896 e 1897 em 307 rebanhos, totalizando 122.673 ovinos, foi relatado $2,28 \%$ de animais apresentando quadro de abortamento e $4,48 \%$ de infertilidade (WATSON, 1962).

Em questionário realizado em 1.330 criatórios ovinos turcos, $85,7 \%$ dos criadores relataram ter observado casos de abortamentos e 0,3\% não souberam responder. Em média 12,6\% das fêmeas acasaladas abortaram e 10,6\% pariram natimortos, índices considerados altos. Os mesmos autores observaram que propriedades que criavam caprinos em conjunto apresentaram fator de risco de 1,95 
para abortamentos, enquanto a presença de caninos, felídeos e bovinos não apresentou associação significativa (YILMAZ et al., 2002).

Nem sempre é possível o diagnóstico em todas as amostras estudadas devido à multifatorialidade de agentes infecciosos que podem estar envolvidos nos casos de aborto, a susceptibilidade de diferentes animais de um mesmo rebanho pode ser variável, fatores ambientais como a temperatura e umidade também podem ser interferentes, bem como as condições de manejo do rebanho (FIGUEIREDO; LAGE; HIRSCH, 2010). Há o grupo de etiologias não infecciosas onde o principal fator não é um agente bacteriológico, viral, fúngico ou parasitário e sim variações de temperatura, excesso de exercício, sal e super fosfato, plantas tóxicas, traumas, por exemplo, por cabeçadas ou porteiras estreitas nas propriedades, coito no final de gestação, fêmeas sub ou superalimentadas predispondo aos quadros de desnutrição ou toxemia da prenhez e distocias (WATSON, 1962; MAVROGIANNI; BROZOS, 2008). Outro parâmetro a ser ressaltado são as provas diagnósticas utilizadas, que nem sempre apresentam a mesma sensibilidade e especificidade para detecção dos agentes (NAVARRO et al., 2009), essa limitação do diagnóstico pode ocorrer devido o tipo de espécime colhido, método de colheita utilizado ocorrendo principalmente contaminação do mesmo com microrganismos presentes no ambiente, volume de material colhido, conservação e transporte inadequados, erros de procedimentos, nesta etapa podem ocasionar a inativação de algum microrganismo presente na amostra, bem como a autólise dos tecidos fetais ou maternos, presença de antibióticos e ação do sistema imune. Na literatura mundial, dados de diferentes locais mostram que somente 30 a $45 \%$ dos fetos encaminhados ao laboratório chega-se a um diagnóstico conclusivo (FIGUEIREDO; LAGE; HIRSCH, 2010).

Na Itália em pesquisa de 292 fetos e 76 placentas de ovinos utilizando a PCR para cinco agentes etiológicos de abortamento (Coxiella burnetii, Chlamydophila abortus, Salmonella enterica sorovar abortusovis, Toxoplasma gondii e Neospora caninum) foi possível o diagnóstico de 41\% (120) e 30,3\% (23/76) das amostras respectivamente (MASALA et al., 2007).

Na Espanha de 35 fetos ovinos abortados, em 13 deles não foi possível a detecção pela PCR e em 12 o diagnóstico pela imunohistoquimica de nenhum dos seis agentes estudados, Chlamydophila abortus, Coxiella burnetii, Salmonella 
Abortusovis, Brucella melitensis, Listeria monocytogenes e Toxoplasma gondii (NAVARRO et al., 2009).

Outra dificuldade para identificação do agente etiológico primário de abortamentos é a ocorrência do diagnóstico de mais de um agente na mesma amostra (MASALA et al., 2007; NAVARRO et al., 2009).

Vários agentes se mostram como potenciais causadores de distúrbios reprodutivos em ovinos. No Brasil há relato de abortamento de ovino da raça Corriedale por protozoário do gênero Sarcocystis $s p$, onde o feto apresentou lesões multifocais não supurativas acentuadas no cérebro e coração associada com áreas de gliose e vasculite linfohistiocitária multifocal moderada e presença de grupos de merontes, alguns em formato de roseta, contendo merozoítos no endotélio vascular e em células endoteliais, especialmente em fragmentos de cérebro e rins (PESCADOR et al., 2007).

A Língua Azul, que é causado por um Orbivírus, está entre as importantes enfermidades causadoras de abortamento no início da gestação sendo que os cordeiros que sobrevivem apresentam viremia persistente excretando o vírus em secreções, incluindo o sêmen. É caracterizada por baixo peso, cordeiros com má formação, tremores e excesso de pelagem ao nascer (DJØNNE, 2007). Pesquisa realizada no estado de São Paulo demonstrou 33,4\% (55/181) de ovinos com histórico de problemas reprodutivos sororeagentes (RIZZO et al., 2010).

A Listeriose possui distribuição mundial afetando uma grande variedade de espécies de mamíferos e aves, incluindo o homem. A encefalite é a forma mais freqüentemente da enfermidade ocorrendo infecção mais comumente em indivíduos adultos e ruminantes que são alimentados com silagem contaminada. Listeria monocytogenes e Listeria ivanovii podem causar abortos em bovinos, ovinos e caprinos. Os abortos geralmente são esporádicos e no final da gestação. Episódios de doença sistêmica ou infertilidade não estão associados aos casos de aborto. As bactérias são eliminadas no leite e descargas uterinas durante alguns meses pósinfecção. Listeria monocytogenes pode causar septicemia em animais jovens, infecções oculares e listeriose neural. No caso da Listeria ivanovii sua associação é exclusivamente ao aborto (DJØNNE, 2007).

A Chlamydophila abortus é freqüentemente associada a distúrbios reprodutivos causando o chamado, Aborto Enzoótico dos Ovinos, possui ampla 
distribuição em regiões criadoras de ovinos, sendo considerada a maior causa de abortamento em ovelhas na Europa. Os abortamentos geralmente ocorrem nas últimas duas ou três semanas de gestação. Pode ainda causar infertilidade devido infecção intrauterina pós monta ou inseminação artificial quando a mesma é eliminada no sêmen (DA SILVA; FREITAS; MULLER, 2006). Pinheiro Júnior et al., (2010) relataram no estado de Alagoas 21,5\% (59/274) de ovinos sororeagentes com títulos $\geq 32$ e $10.2 \%$ de suspeitos com títulos menores que $\geq 16$

Os Micoplasmas possuem algumas espécies envolvidas com distúrbios reprodutivos em ovinos, Kapoor, Singh e Pathak (1984) demonstraram isolamento de Mycoplasma mycoides subespécie capri em rebanho ovino com problemas reprodutivos. Mycoplasma capricolum tem sido isolado em casos de vulvovaginite (JONES, 1983). Mycoplasma ovino sorogrupo 11 foi isolado na Inglaterra do trato genital de ovelhas que apresentavam problemas de infertilidade (NICHOLAS et al., 1999). Ball et al. (1985) e Livingstone Junior e Gauer (1982) isolaram ureaplasma sorotipo IX de ovinos como responsável por casos de infertilidade e aborto nessa espécie.

O gênero Salmonella se resume a uma única espécie a Salmonella entérica, que é dividida em sete subespécies e cerca de 2.000 sorotipos. A subespécie I, Salmonella entérica subespécie entérica contém a maioria dos sorotipos de Salmonellas que são patógenos de animais. A subespécie IIlb, como a Salmonella entérica subespécie diarizona é especialmente patogênico para ovinos. Embora a principal manifestação da salmonelose seja a diarréia, diferentes sorotipos podem causar abortos esporádicos em bovinos, ovinos e eqüinos, sem manifestação clinica de doença sistêmica. Abortamentos podem ocorrer em rebanhos onde ocorra surto entérico da doença. A transmissão é fecal-oral através da eliminação de animais portadores. O diagnóstico é baseado principalmente no isolamento e identificação do agente da placenta e fetos. Salmonella entérica subespécie diarizona acomete principalmente os ovinos causando abortos sem manifestação clínica (DJØNNE, 2007).

Anaplasma phagocytophilum é o agente causador da anaplasmose em seres humanos, cavalos, ovinos, bovinos, cães e gatos. As bactérias são transmitidas pelo carrapato Ixodes ricinus, a infecção ocorre pela picada do artrópode infectado e em seguida a bactéria se instala nos granulócitos e monócitos de mamíferos. A doença 
é relativamente leve, com apatia, febre e imunossupressão. Abortos e natimortalidade são comumente observados em ovinos e bovinos (DJØNNE, 2007).

\subsection{Infertilidade x Nutrição}

O estado nutricional dos ovinos possui forte influência na qualidade reprodutiva. A superalimentação e desnutrição têm sido descritas como prejudicial para o desenvolvimento embrionário. Ovelhas subnutridas apresentam menor fecundação oocitária, redução no ritmo do desenvolvimento e viabilidade dos embriões. Há importante influência da nutrição durante a maturação oocitária e viabilidade embrionária, reduzindo a sensibilidade do endométrio à progesterona, alterando a sensibilidade do endométrio para hormônios esteróides nas fases iniciais da gestação, consecutivamente mudando negativamente 0 ambiente uterino aumentando assim os índices de morte e absorção embrionária e conseqüente repetição de cio (ABECIA et al., 2006). Abecia et al. (1997) observaram retardo no desenvolvimento embrionário oito dias após 0 acasalamento em ovelhas subnutridas, no entanto o efeito da desnutrição sobre a taxa de prenhes só foi observada após a segunda semana de gestação onde ocorreu a diminuição da quantidade de embriões colhidos.

O excesso de proteína também pode se tornar um fator preponderante na reprodução. Berardinelli et al. (2001), ao estudar ovelhas que consumiam proteína degradável em excesso observaram dificuldade de deslocamento dos embriões até - quinto dia de desenvolvimento e após esse período, um acelerado desenvolvimento embrionário no oviduto, assim como McEvoy et al. (1997), que observaram retardo no desenvolvimento dos embriões de ovelhas suplementadas com uréia, concluindo que excesso de nitrogênio degradável no rúmen eleva os níveis de uréia plasmática e os níveis de amônia no útero, causando aumento da mortalidade embrionária. Os estudos citados demonstram que o excesso ou falta de alimentos causam alterações fisiológicas no ambiente uterino e no desenvolvimento embrionário que serão refletidos em casos de infertilidade. 
2.3 Nascimento de cordeiros "fracos" e morte neonatal

O nascimento de cordeiros "fracos" geralmente está relacionado ao baixo peso ao nascer que pode estar associado às práticas de manejo e nutricionais inadequadas, época do ano, sexo, uma vez que machos geralmente apresentam maior peso ao nascer e número de cordeiros paridos. Conseqüentemente o nascimento de cordeiros "fracos" e/ou morte neonatal é mais observado em casos de partos múltiplos, nascimento de fêmeas, ovelhas primíparas e/ou fêmeas cobertas na puberdade, nutrição deficiente no momento do coito e terço final de gestação, escore corporal igual ou inferior a dois no momento do parto, influência do clima no momento da gestação e parto em temperaturas elevadas que irão diminuir a disponibilidade de alimento e em baixas temperaturas onde $\mathrm{s}$ gestantes e cordeiros estarão mais predispostos a afecções pulmonares. Todos esses fatores tornam os cordeiros mais suscetíveis à morbidade e mortalidade neonatal. (GARDNER et al., 2007)

Em estudo norueguês o índice de natimortalidade foi de 3,4\% e 4,1\% nos rebanhos em 2001 e 2006 respectivamente, podem-se observar diferentes etiologias para os quadros observados. Em 74 cordeiros natimortos, 28 deles não apresentaram lesões detectáveis e em 21 haviam lesões características de traumas. Sinais inespecíficos como edema subcutâneo e líquido intracavitário foram vistos em 13 animais. As demais alterações detectadas foram: malformações, enterite, afogamentos, torção de abomaso, dois fetos apresentaram-se mumificados e outros dois mortos no momento do parto. Os autores sugerem que devido à dificuldade de se apontar as causas específicas das mortes, possivelmente as mesmas tenham ocorrido devido disfunção placentária, uma vez que a morte neonatal ocorreu em cordeiros com baixo peso ao nascer e os traumas devido a partos distócicos ou por tentativas da mãe levantar seu cordeiro, que por nascer com baixo peso e fraco permanece deitado e recebe estímulos, como golpes com membros e cabeça que podem causar traumas (DRAGSET; HEKTOEN; OPHEIM, 2007).

Septicemia neonatal em cordeiros com menos de uma semana de idade, pode ser causada por Escherichia coli, Arcanobacterium pyogenes, estreptococos, estafilococos e outras bactérias causando septicemia, artrite e meningite. As 
infecções são geralmente transmitidas através do cordão umbilical, e os animais podem morrer dentro de poucos dias após o início da infecção (DJØNNE, 2007).

2.4 Agentes e fatores relacionados à queda de fertilidade nos carneiros

As alterações no trato reprodutivo dos carneiros possuem diversas possibilidades etiológicas, como por exemplo, no caso do aumento do volume escrotal que pode ser causado devido: orquite, epididimite, hidrocele, hematocele, varicocele, neoplasias, hérnias inguinais, inflamação dos envoltórios entre outros. Os agentes bacterianos mais importantes em casos de alterações testiculares são as Brucellas, Actinobacillus seminis, Histophilus somnus, Corynebacterium spp, Streptococcus, Staphylococccus, Pseudomonas, Pasteurellas, Arcanobacterium pyogenes, Escherichia coli (PASTOR, 2006), Chlamydophila abortus (DA SILVA; FREITAS; MULLER, 2006) além dos Ureaplasmas e Micoplasmas responsáveis por casos de balanopostites (KIDANEMARIAM et al., 2005).

Podemos citar como etiologias não bacterianas das alterações testiculares e/ou seminais: nutrição, baixo escore corporal relacionado a doenças crônicas ou parasitárias, má nutrição e envelhecimento. Falta de Zinco, Magnésio e vitamina $A$ podem levar a atrofia e hipoplasia testicular (LOSTE; RAMOS; SÁEZ, 2001). Importante ressaltar também as intoxicações por plantas como Férula communis que causa epididimite devido lesões do epitélio seminífero e ducto epididimário, edema, presença de conteúdo hemorrágico no escroto e espessamento dos envoltórios testiculares (GIL ANAYA et al., 2001) e Astragalus lentiginosus que causa degeneração testicular por lesão dos túbulos seminíferos, epidídimo e ducto levando a queda de libido quedq nq produção espermática (PANTER et al., 1989). O decúbito pode levar alterações testiculares devido à compressão dos órgãos nos casos de animais que permanecem muito tempo deitados, devido a problemas podais e defeitos congênitos como hipoplasia, criptorquidismo e espermatocele (PASTOR, 2006). Protozoários como a sarna corióptica causada por Chorioptes bovis que quando afeta a pele escrotal aumenta sua temperatura causando atrofia, miíase cutânea, tripanosomiasis e besnoitiosis (RHODES, 1976). Vírus da Maedi- 
Visna, Varíola e Ovina, Border Diseases (PALFI; GLAVITIS; HAJTÓS, 1989). Na seqüência serão revisadas as principais características relacionadas aos distúrbios reprodutivos observados na espécie ovina quando infectadas pelas bactérias; Actinobacillus seminis, Brucela ovis, leptospirose, campilobacteriose e Histophilus somni e os protozoários Toxoplasma gondii e Neospora caninum estudados.

\subsection{Actinobacillus seminis}

O primeiro isolamento de Actinobacillus seminis ocorreu na Austrália por Baynes e Simmons (1960) em ovinos que apresentavam quadro de epididimite. Posteriormente foi isolado nos Estados Unidos (LIVINGSTON JUNIOR; HARDY, 1964; SWIFT et al., 1982; SPONENBERG et al., 1983), África do Sul (WORTHINGTON; BOSMAN, 1968; ERASMUS; WET; PROZESKY, 1982), Nova Zelândia (GUMBRELL; SMITH, 1974; BRUERE et al., 1977), Hungria (HAJTÓS, 1987; HAJTÓs et al., 1987), Argentina (ROBLES et al., 1990), Kenya (MBAl et al., 1996) e Reino Unido onde foi considerado importante agente causador de infertilidade em carneiros (HEATH et al., 1991; LOW et al., 1995). No México a bactéria foi isolada em duas amostras seminais de animais não reagentes sorologicamente (NAREZ et al., 1999). Na Espanha ocorreu o primeiro relato realizado no sul da Europa (PUENTE-REDONDO et al., 2000).

No Brasil existem apenas três relatos de isolamento. Dois oriundos de criatórios do Rio Grande do Sul, sendo o primeiro em 1992 de ovino da raça Texel (SCHREINER et al., 1992) e o segundo de Gomes et al. (2001) que relataram 5 carneiros com quadro de epididimite e isolamento seminal positivo entre 33 reprodutores da raça Corriedale que foram submetidos ao exame clínico do aparelho reprodutor, as lesões eram semelhantes às encontradas em casos de Brucelose ovina. Por último Gregory et al. (2009), relataram no estado de São Paulo, o isolamento no sêmen de ovino da raça Dorper que apresentava quadro de epididimite e orquite unilateral, azospermia e baixo índice de fertilidade pós estação de monta. 
Saunders et al. (2007) testando o sêmen de 295 reprodutores que seriam encaminhados a centrais de colheita na Austrália detectaram Actinobacillus seminis pela PCR em 29 animais e em 79,3\% dessas amostras foi possível o isolamento bacteriano, sendo que em 11 delas foi detectado Histophilus somni.

Há relato na Austrália de outra espécie da bactéria causando orquiteepididimite purulenta em ovino da raça Border Leicester, o Actinobacillus lignieresi, que inoculado em ovino saudável causou o mesmo quadro observado na infecção natural (LAW; ELDER, 1969).

Inoculações experimentais do Actinobacillus seminis realizadas no Peru por Dibarrat et al. (2006), sugerem que as glândulas anexas podem ser o reservatório da bactéria. Essa é uma hipótese a ser considerada pois carneiros inoculados por 9 vias diferentes sendo elas; intra-venosa, intra-muscular, intra-epididimal, intra-uretral, intra-prepucial, ducto deferente, oral, intra-nasal e ocular, apresentaram alterações patológicas em glândulas anexas que variaram de aguda a crônica, supurativa e não supurativa como; ampolite, deferentite, bulbo-uretral adenite e uretrite, com isolamento do patógeno em glândula vesicular, ductos deferentes, ampola e prepúcio, mostrando susceptibilidade da região a infecção e predileção da bactéria se instalar. Não foram observadas alterações nos animais inoculados por via nasal e ocular (AL-KATIB; DENNIS, 2008b).

Simmons, Baynes e Ludford (1966) isolaram Actinobacillus seminis das glândulas vesiculares e bulbo uretral, corpo do epidídimo e sêmen de carneiros naturalmente infectados, no entanto não obtiveram sucesso no isolamento em amostras de leite, muco vaginal, cotilédones útero e orgãos de natimortos de fêmeas soropositivas.

Sua patogenia é incerta, Jansen (1983) sugeriu que Actinobacillus seminis, por ser um microorganismo oportunista presente na cavidade prepucial, é capaz de colonizar as partes profundas do trato genital, provocando epididimite em animais jovens que apresentem precocidade sexual. Outra hipótese é que lesões traumáticas no epidídimo, liberem histamina e favorecem o acúmulo de pequenas quantidades de fluídos ricos em proteínas que propiciam a colonização desses microorganismos. Estes traumas podem causar a ruptura do epidídimo, iniciando a formação de granulomas espermáticos mediados por condições auto-imunes sem presença de bactérias (BULGIN; BRUSS; ANDERSON, 1990). Por ultimo sugere-se 
a participação de fatores hormonais na migração do Actinobacillus seminis da mucosa peniana até epidídimo e testículos, considerando que ocorrem mudanças no trato reprodutivo durante a puberdade, especialmente as células do epitélio epididimal facilitando a infecção descendente do trato reprodutivo (JANSEN, 1980).

Al-Katib e Dennis (2008b) demonstraram a possibilidade de ocorrer a infecção de forma ascendente e descendente no trato reprodutivo de ovinos após realizar inoculação experimental através de nove vias diferentes

Acomete carneiros quando alcançam a maturidade sexual, pois está presente na microflora da cavidade prepucial e mucosa peniana de ovinos jovens (BULGIN; ANDERSON, 1983; BULGIN, 1990; BAGLEY; HEALEY, 1997), porém por ser uma condição irreversível, também é diagnosticada em carneiros adultos (SIMMONS; BAYNES; LUDFORD, 1966; WET; ERASMUS, 1984).

Wet e Erasmus (1984) ilustraram bem essa afirmação quando realizaram diagnóstico bacteriológico para Actinobacillus seminis e Brucella ovis em 7.610 carneiros divididos em seis faixas etárias; cordeiros, carneiros de dois, quatro e seis dentes, carneiros de "boca cheia" e animais idosos, onde apenas 4,4\% dos machos dentre todas as idades apresentavam lesões clínicas. Foi observada maior freqüência de animais positivos para Actinobacillus seminis em cordeiros e carneiros de um dente em relação à Brucella ovis. Nas demais faixas etárias ocorreram decréscimo no número de isolamentos conforme aumento da idade. Os isolados de Brucella ovis se apresentaram de forma crescente em relação à idade dos animais.

Swift et al. (1982) isolaram Actinobacillus seminis de 5 carneiros, com orquite unilateral e abscesso testicular de 186 ovinos com idade inferior aos 9 meses, não reagentes e imunizados contra Brucella ovis, indicando que a vacinação contra a mesma não protege os machos contra outros agentes causadores de epididimite ovina.

Walker e LeaMaster (1986) isolaram Actinobacillus seminis, através de zaragatoa prepucial, em 34\% (17/50) de ovinos com 6 meses de vida, não obtiveram nenhum isolamento nos 25 carneiros com mais de 2 anos e relataram, após acompanharem cordeiros do nascimento até 1 ano de idade, que com 20 semanas de vida esses animais são mais colonizados pela bactéria. Todos os machos utilizados no estudo não apresentam lesões palpáveis em testículos e epidídimos. Esses dois estudos demonstram maior exposição de animais jovens à bactéria. Uma 
freqüência maior de isolamentos foi observada quando no mesmo estudo, buscaram isolar o microorganismo através de zaragatoa vaginal, as fêmeas com menos de 6 meses apresentaram $88 \%$ (22/25) de isolamentos enquanto as adultas com mais de 2 anos apenas $8 \%$ (2/25), mostrando maior risco da transmissão venérea em casos de carneiros que são colocados para cobrirem fêmeas jovens e/ou nulíparas (WALKER; LEAMASTER, 1986).

A alta incidência da bactéria em ovinos jovens e/ou que não iniciaram sua vida reprodutiva sugere que a via venérea não seja uma via importante de transmissão do mesmo (SIMMONS; BAYNES; LUDFORD, 1966; SWIFT et al., 1982; WALKER; LEAMASTER, 1986; MBAl et al., 1996; PUENTE-REDONDO et al., 2000).

Os animais acometidos por Actinobacillus seminis geralmente apresentam epididimite e/ou orquite unilateral palpável, sendo no epidídimo a cauda a região mais afetada, abscessos com exsudato fibropurulento e aumento do volume do escroto. Animais com sinais clínicos da fase crônica da doença apresentam hipoplasia testicular, nódulos no epidídimo e adesões fibrosas entre a túnica albugínea e vaginal (BAYNES; SIMMONS, 1968; MBAl et al., 1996; PUENTEREDONDO et al., 2000; AL-KATIB; DENNIS, 2005, 2007; GREGORY et al., 2009). No sêmen ocorrem anormalidades morfológicas, presença de células inflamatórias, queda da motilidade e vigor, causando, de acordo com o grau da lesão, infertilidade (BAYNES; SIMMONS, 1968; LOW et al., 1995; MBAl et al., 1996; GOMES et al., 2001).

Geralmente não são observados sinais clínicos sistêmicos (AL-KATIB; DENNIS, 2005), no entanto nos casos de epididimite aguda com presença de abscessos, o animal pode apresentar febre, depressão e anorexia (BAYNES; SIMMONS, 1968; SPONENBERG et al., 1983).

Em inoculação experimental Al-Katib e Dennis (2008a) relataram que as $24 \mathrm{e}$ 72 horas pós inoculação intra-epididimal foi observado epididimite supurativa e granuloma espermático, respectivamente, todos os 16 animais desafiados apresentaram algum tipo de lesão na cauda do epidídimo e histologicamente foram notados infiltrados eosinofílicos, como resposta precoce de combate a bactéria, que pode estar relacionado com a patogenia da epididimite.

Em estudo no México, de 10 carneiros sorologicamente positivos apenas 2 apresentavam orquite e epididimite clínica sendo que um deles era positivo também 
a Brucella ovis (NAREZ et al., 1999), mostrando que nem sempre a infecção é seguida de manifestações clínicas testiculares.

$\mathrm{Na}$ África do Sul foram isoladas 443 amostras seminais positivas para Actinobacillus seminis de 905 animais que apresentavam alterações clínicas na inspeção, palpação do trato reprodutivo e/ou presença de neutrófilos no sêmen (WET; ERASMUS, 1984).

Há relato de isolamento de Actinobacillus seminis de articulação de cordeiros que vieram a óbito ou apresentaram claudicação devido poliartrite purulenta e prepúcio de carneiro com quadro de postite severa (WATT; BAMFORD; NAIRN, 1970).

Actinobacillus seminis geralmente não é associado a casos de abortos em ovinos, no entanto há relato de isolamento da bactéria em feto ovino abortado na Hungria (HAJTÓS, 1987) e em três casos no Reino Unido (FOSTER et al., 1999). Inoculações intravenosas da bactéria realizado por Smith e Hughes (1974) no meio e no final de gestação causaram abortamentos e partos prematuros associados a placentite necrótica.

Inoculação experimental na glândula mamária causou mastite gangrenosa aguda (WATT; BAMFORD; NAIRN, 1970).

Essa enfermidade causa significante perda econômica quando afeta animais de alto valor zootécnico, pois o tratamento antibiótico não é eficaz no combate da bactéria no trato reprodutivo (ERASMUS; WET; PROZESKY, 1982; HEATH et al., 1991; GREGORY et al., 2009).

\subsection{Brucella ovis}

As Brucellas pertencem ao grupo alfa das Proteobactérias e a família Rhizobiaceae, são cocobacilos pequenos, gram-negativos, medindo de 0,6-1,5 $\mu \mathrm{m}$ de comprimento e 0,5-0,7 $\mu \mathrm{m}$ de diâmetro. São estritamente aeróbios, catalase positiva e oxidase geralmente positiva. Suas 8 espécies podem ser encontradas em diferentes mamíferos como a Brucella abortus em bovinos e ungulados selvagens, Brucella melitensis em caprinos, ovinos e ungulados selvagens, Brucella ovis em 
ovinos, Brucella suis em suínos, lebres, renas e roedores silvestres, Brucella neotomae em roedores do deserto, Brucella cetaceae em cetáceos e Brucella pinnipediae em pinípedes, como focas, leões marinhos. Todas as espécies de Brucellas que acometem os mamíferos terrestres são importantes zoonoses com exceção da Brucella ovis que não apresenta risco ao homem (MAURIN, 2005).

Brucelose ovina pode ser causada pela Brucella ovis que é conhecida por ser uma bactéria de parede rugosa ou Brucella melitensis, uma bactéria de parede lisa, ambas as espécies podem produzir anormalidades testiculares, epididimais e abortamentos, no entanto Brucella ovis afeta de forma especial o sistema genital de carneiros, produzindo quadro característico denominado Epididimite Contagiosa dos Ovinos (NAREZ et al., 1999), podem ocorrer também infecções de ovinos pela Brucella abortus principalmente em propriedades com criação consorciada a bovinos (OCHOLI et al., 2005; PINHEIRO JUNIOR et al., 2008).

Brucella ovis possui distribuição mundial e acomete exclusivamente a espécie ovina, embora tenha ocorrido infecção natural em cervídeos (Cervus elaphus), a doença não foi relatada em nenhuma outra espécie animal, experimentalmente foi observada infecção em animais de laboratórios e caprinos (RIDLER, 2002). Não há relatos que essa espécie de Brucella afete humanos (NAREZ et al., 1999).

Após a primeira descrição da infecção por Buddle e Boyes (1953) e Buddle (1956) isolou estirpes de Brucella na Nova Zelândia e Austrália.

No Brasil o primeiro diagnóstico clínico de Brucelose por Brucella ovis foi firmado por Ramos et al. (1966) após examinarem 3.317 reprodutores ovinos e observarem 220 com sinais clínicos de epididimite ovina. A confirmação foi realizada por Blobel et al. (1972) que a isolaram em 8 epidídimos provenientes de 24 carneiros com epididimite e sêmen necrospérmico ou azoospérmico contendo leucócitos e bactérias semelhantes à Brucellas.

Nozaki et al. (2004), examinaram 1.033 ovinos do estado de São Paulo e encontraram 12\% de sororeagentes para Brucella ovis. Azevedo et al. (2004c), no Rio Grande do Norte, encontraram 11,3\% de positivos em 115 animais por imunodifusão em gel de ágar (IDGA). Clementino et al. (2007) obtiveram 5,57\% (28/498) de carneiros deslanados sororeagentes na Paraíba, sendo que 8,59\% (25/283) das propriedades investigadas apresentaram um ou mais carneiros sororeagentes. 
Ueno (2010) testou 1.529 soros de ovinos pertencentes a 51 propriedades da região oeste do estado de São Paulo pela prova de imunodifusão em gel de ágar (IDGA), utilizado como teste de triagem e posteriormente os soros positivos foram submetidos novamente ao teste acrescido de solução de 2-mercaptoetanol (IDGA/2$M E)$, prova confirmatória. Do total de amostras, 1,70\% (26/1529) foram positivas na IDGA e, destas, apenas quatro foram positivas na IDGA/2-ME, entre elas um soro de macho. Das 51 propriedades, $16(31,37 \%)$ apresentaram pelo menos um animal positivo na triagem e 4 apresentaram ao menos um positivo para teste confirmatório.

Epstein et al. (1964) na Argentina examinaram 1.182 carneiros encontrando 15,3\% (181) com epididimite, enquanto Alonso et al. (2007) na região de Pampa de Achala, Córdoba, não observaram nenhum animal positivo para Brucella ovis em 1.507 amostras. Robles et al. (1998) por sua vez acompanhando rebanho com em média 600 reprodutores, durante 3 anos relatou crescimento da prevalência de $2,1 \%, 4 \%, 6,3 \%$ durante os anos. No México obteve-se 9\% (10/111) de machos reagentes com isolamento em duas de 17 amostras seminais (NAREZ et al., 1999).

No Reino Unido, pesquisa em rebanhos de diferentes raças de ovinos apresentou 2,5\%, $19 \%$ e $26 \%$ de animais positivos para as raças Merino, Border Leicester e Dorset respectivamente (SERGEANT, 1994). Na Espanha obteve-se 0,7\% de ovinos sororeagentes (REVIRIEGO; MORENO; DOMíNGUEZ, 2000). Arsenault et al. (2004) não encontraram nenhum ovino sororeagente entre os 224 machos e 34 fêmeas testados no Canadá enquanto Lundervold et al. (2004) encontraram apenas 1,3\% (7/542) no Cazaquistão.

Nos rebanhos ovinos iraquianos a presença de Brucellas é baixa, estudos realizados por diferentes autores demonstram prevalências de $1 \%, 1,34 \%, 5,5 \%$, $6,74 \%$ e $7,1 \%$ (SHAREEF, 2006). Na Jordânia de 1.380 animais obteve-se $37,6 \%$ de animais positivos em 31 das 66 propriedades pesquisadas (AI-MAJALI et al., 2007). Em reprodutores ovinos destinados as centrais de inseminação artificial Australiana a incidência de isolamento e detecção pela PCR foi de 1,02\% (3/295) (SAUNDERS et al., 2007).

A infecção por Brucella melitenses nos ovinos parece ocorrer endemicamente na região Mediterrânica, especialmente ao longo da costa norte e leste prolongandose através da Ásia Central até o sul da Península Arábica e Extremo Oriente na Mongólia. Países da América também são afetados especialmente México, Peru e 
norte da Argentina. Está presente também na África e Índia. Regiões como América do Norte, exceto México, norte da Europa, sudeste da Ásia, Austrália e Nova Zelândia acredita-se que são livres da enfermidade (BENKIRANE, 2006). Não há evidências da existência de Brucella melitensis nos rebanhos brasileiros (POESTER; GONÇALVES; LAGE, 2002).

A infecção por Brucella melitenses foi observado na Guatemala (Moreno, 2002) e Jordânia com o isolamento de Brucella melitensis biótipo 3 em 8 de 21 fetos abortados (Al-MAJALI et al., 2007). Resultados de programas Europeus de erradicação da Brucella melitensis em pequenos ruminantes nos anos de $1999 \mathrm{e}$ 2000 mostram prevalência de $0,16 \%$ e $0,05 \%$ na França, 2,51\% e 1,86\% na Grécia, $4,71 \%$ e 3,56\% na Itália, 7,2\% e 6,36\% em Portugal e 19,49\% e 15,62\% na Espanha (GODFROID; KÄSBOHRER, 2002). No México, apesar de sua presença, LunaMartínez e Mejía-Terán (2002) relatam que são raros abortamentos causados por essa espécie de Brucella.

A prevalência de Brucella abortus em ovinos foi pesquisada no Brasil por Nozaki et al. (2004) sem sucesso em São Paulo e por Pinheiro Junior (2008) em Pernambuco que observaram 2,5\% (9/360) de animais sororeagentes a técnica de antígeno acidificado tamponado (AAT), sendo 5 fêmeas e 4 machos.

Ocholi et al. (2005) relataram em rebanho com cinco casos de abortamentos no terceiro mês de gestação, 14,3\% (4/28) de animais sororeagentes, 5 amostras de leite positivas ao teste do anel do leite e isolamento em leite e secreção vaginal de Brucella abortus biotipo 1, esse mesmo biótipo estava presente nos bovinos criados na propriedade.

$\mathrm{Na}$ Turquia foi realizada pesquisa para Brucella abortus em 400 animais provenientes de 16 rebanhos com histórico de abortamento pelos testes de Rosa Bengala, Soro-aglutinação, Fixação de Complemento e Antígeno Acidificado obtendo a incidência de $36,7 \%, 35,5 \%, 33,75 \%$ e $34,75 \%$ respectivamente em 14 dos rebanhos, não havendo diferença estatística entre os testes diagnósticos realizados (CELEBI; ATABAY, 2009).

Brown, Pietz e Price (1973), demonstraram transmissão de Brucella ovis de machos artificialmente infectados para fêmeas não infectadas, através do coito. Essas mesmas fêmeas foram fontes de infecção para outros machos não infectados após acasalamento, confirmando a transmissão venérea do agente. 
Quispe, Rivera e Rosadio (2002) observaram rápida disseminação da enfermidade durante 60 dias de estação de monta no Peru, durante esse período foi observado 27 novos casos de machos sororeagentes em rebanho de reprodutores com prevalência pré estação de monta de $58,7 \%$ (101/172) de machos positivos a Brucella ovis.

A atividade homossexual de carneiros fora da estação de monta é outra forma importante de infecção da enfermidade (ROBLES, 1998).

Devido à capacidade de aderência a zona pelúcida, a Brucella ovis pode ser vastamente disseminada através da transferência de embriões, sendo que a técnica de lavagenm do material a ser transferido com penicilina e estreptomicina, nem sempre é eficaz (WOLFE et al., 1988). Palhetas de sêmen podem ser outra fonte de disseminação da doença entre as fronteiras (RIDLER, 2002), além da importação de reprodutores como ocorreu com o México que teve seu primeiro relato da doença em 1979 de machos Suffolk importados dos E.U.A. (LUNA-MARTíNEZ; MEJíA-TERÁN, 2002).

Coelho et al. (2007) estudaram os fatores de risco associados a rebanhos de pequenos ruminantes portugueses com presença de animais sororeagentes a brucelose e relataram as seguintes características com potencial de aumentar a probabilidade de infecção: rebanhos com mais de 116 animais $(\mathrm{OR}=2,99)$, remoção inadequada de fezes e falta de higiene nas instalações $(\mathrm{OR}=2,87)$, não higienização de bebedouros $(O R=3,05)$, introdução de animais de rebanhos não livre de brucelose ou de estado sanitário desconhecido $(\mathrm{OR}=12,11)$ demonstrando a importância do manejo sanitário para controle da enfermidade. Foi observada também a diminuição da chance de infecção por Brucellas em propriedades onde os responsáveis tinham 55 anos de idade ou mais $(\mathrm{OR}=0,4)$.

$\mathrm{Na}$ Jordânia os fatores de risco observados para o contágio foram: adição de novos animais ao rebanho $(\mathrm{OR}=2,8)$, contato entre rebanhos ovinos $(\mathrm{OR}=1,8)$, empréstimo de machos durante a estação reprodutiva $(\mathrm{OR}=1,9)$ (AL-MAJALI et al., 2007) e pastagem em piquetes comuns a diferentes rebanhos $(\mathrm{OR}=22,60)$ ( $A L$ TALAFHAH; LAFI; AL-TARAZI, 2003). Reviriego, Moreno e Domínguez (2000) na Espanha descreveram que contato entre ovinos de diferentes propriedades e pastagens comuns a diferentes rebanhos possuem fator de risco de contágio da doença significante. 
A vacinação com vacina Rev-1 mostrou-se como um fator de proteção a infecção (OR= 0,01 e 1,7) (AL-TALAFHAH; LAFI; AL-TARAZI, 2003; Al-MAJALI, et al., 2007), assim como a freqüência de práticas de desinfecção mais de três vezes ao ano $(\mathrm{OR}=0,02)$ (REVIRIEGO; MORENO; DOMÍNGUEZ, 2000), uso de desinfetantes, fornecimento de água encanada (AL-TALAFHAH; LAFI; AL-TARAZI, 2003) e disponibilidade de serviço veterinário no criatório (MAINAR; VÁZQUEZBOLANDE, 1999).

No estado da Paraíba, a freqüência da higiene das instalações foi à característica associada ao aumento do risco de infecção pela Brucella ovis em carneiros, pois em propriedades onde a higienização era realizada diária, semanal e/ou mensalmente não apresentaram animais sororeagentes, contra 7,2\% (6/77) e $12,5 \%$ (18/126) das propriedades que não higienizavam e realizavam semestral ou anualmente, respectivamente (CLEMENTINO et al., 2007).

Experimentalmente, a Brucella ovis possui período de incubação de quatro a seis semanas, tempo que o animal leva para eliminar a bactéria no sêmen. As lesões se manifestam a partir da nona semana pós infecção, segundo Quispe, Rivera e Rosadio (2002), enquanto Paolicchi et al. (2000), observaram lesões palpáveis a partir da sexta semana.

Após a exposição do organismo a mucosas e membranas do animal, ocorre bacteremia e instalação do microorganismo em epidídimos, ampola e vesículas seminais (BIBERSTEIN et al., 1964). Em cerca de 30 a $40 \%$ dos carneiros infectados é notado através da palpação o aumento de volume de alguma região do epidídimo (HUGHES; CLAXTON, 1968). Paolicchi et al. (2000), em carneiros experimentalmente infectados, relataram lesões em $71,4 \%$ (10/14) dos animais.

A infecção geralmente é disseminada e pode causar infertilidade em machos, abortamento em fêmeas e mortalidade neonatal em cordeiros. Os sinais clínicos iniciais da infecção de ovinos por Brucella ovis são: febre, acompanhada de desgaste físico, dispnéia e aumento de volume do escroto devido inflamação testicular (BUDDLE, 1956; ROBLES, 1998). Os principais órgãos acometidos são: epidídimo, túnica vaginal e testículos nos machos e placenta nas fêmeas. (BUDDLE, 1956).

Animais naturalmente infectados apresentam epididimite (CAMERON; LAUERMAN JUNIOR, 1976; BURGESS; McDONALD; NORRIS, 1982) e podem 
excretar o microorganismo no sêmen ou apenas apresentarem resposta sorológica sem a presença de sinais clínicos no aparelho reprodutor (BURGESS; McDONALD; NORRIS, 1982; QUISPE; RIVERA; ROSADIO, 2002).

A primeira região e ser afetada é a cabeça do epidídimo que se encontra aumentada em seu tamanho de quatro a cinco vezes e de aspecto irregular, em casos agudos os testículos estão aumentados de tamanho, há edema inflamatório, presença de exsudato fibrinoso na região da túnica vaginal, hiperemia testicular e edema do epidídimo (EPSTEIN et al., 1964; ROBLES, 1998).

$\mathrm{Na}$ fase crônica, são observadas regiões no testículo hipertrofiadas e endurecidas à palpação, deformações na cauda do epidídimo, pele do escroto espessa com fibrosamento que restringe a mobilidade do testículo, ocorrendo inclusive aderências fibrosas obstruindo a cavidade que separa as túnicas (RIDLER, 2002; ROBLES, 2004).

Geralmente, em casos de orquite/epididimite por Brucella ovis, ao corte dos órgãos reprodutivos observa-se extravasamento de exsudato amarelado de consistência cremosa e histologicamente presença de granulomas nas três porções do epidídimo, cistos epiteliais, infiltrado de células mononucleares e esclerose de vasos (NAREZ et al., 1999).

Experimentalmente os sinais clínicos se assemelham a infecção natural, ocorrendo degeneração, atrofia e mineralização testicular, aderências testiculares, deformações, aumento de volume, presença de massas caseosas e cistos purulentos nos epidídimos, sendo a maior incidência de granulomas espermáticos na cauda. Histologicamente foi observado epididimite, vesiculite, ampulite crônica, aglomerado de neutrófilos e macrófagos fagocitando espermatozóides e células gigantes em contato direto com células mononucleares (PAOLICCHI et al., 2000).

A presença de leucócitos no sêmen de carneiros é um indicativo de infecção clínica causada por Brucella ovis, podendo ser utilizado como técnica de triagem (KIMBERLING et al., 1986). De 887 reprodutores ovinos examinados, 80 apresentavam leucócitos no ejaculado, destes, 67,5\% (54) com cultura positiva para Brucella ovis. Em amostras fracamente positivas para Brucella ovis, os ejaculados estavam aquosos, sêmen pouco denso, acompanhado de coágulos mucosos e presença de células inflamatórias. Nos casos em que haviam muitas células 
inflamatórias foram encontradas bactérias fagocitadas no interior dos neutrófilos (WIEMER; RUTTLE, 1987).

Uma das causas da queda da fertilidade causada pela presença de Brucella ovis é devido à presença de leucócitos no ejaculado que produzem citocinas, fator de necrose tumoral- $\alpha$ e radicais livres que reduzem a motilidade e o potencial de fertilidade dos espermatozóides, além do sistema imune que produz resposta antiespermática de longa duração nas células infectadas (PAOLICCHI et al., 2000).

Também ocorre a perda na qualidade seminal devido à queda da concentração e motilidade, aumento de espermatozóides sem cabeça e com defeitos de cauda (CAMERON; LAUERMAN JUNIOR., 1976). Kott et al. (1988) compararam ejaculados de carneiros naturalmente infectados com os de machos livres de Brucellas e descreveram o sêmen de animais positivos com menor motilidade, aumento do número de células espermáticas anormais e com defeitos de cabeça, menor porcentagem de espermatozóides vivos e alta concentração de células brancas no ejaculado e sangue desses animais.

Em animais experimentalmente infectados Paolicchi et al. (2000), observaram oligospermia, presença de células inflamatórias, esfregaço seminal contendo bactérias rodeadas por fagócitos, no entanto 0 isolamento no sêmen e órgãos genitais ocorreu em apenas $57 \%$ e $36 \%$ dos animais, $(n=14)$, respectivamente.

Fêmeas artificialmente infectadas no segundo mês de gestação apresentaram morte neonatal e nascimento de cordeiros saudáveis, sendo possível o isolamento em placentas e detecção de títulos para Brucella ovis no colostro (RIS, 1970). Ocholi et al. (2004) isolaram Brucellas em leite e zaragatoa vaginal de ovelhas que haviam abortado.

Al-Talafhah, Lafi e Al-Tarazi (2003) estudando 8 propriedades da Jordânia, observaram $20 \%$ de média de abortamentos nos rebanhos e relataram que desses, $13 \%$ eram causados por Brucella melitensis.

O diagnóstico pode ser realizado por exames semiológicos associados a bacteriológicos como observado em estudo realizado na África do Sul durante 1981 a 1983 onde foram examinados por inspeção, palpação e presença de neutrófilos no sêmen 15.225 carneiros. Os animais que apresentaram alterações clínicas (905) foram submetidos a exame bacteriológico que diagnosticou 662 isolados de Brucella 
ovis, sendo que a raça Dorper apresentou o dobro da porcentagem de animais com alterações clínicas em relação à raça Merino (WET; ERASMUS, 1984).

Buckrell et al. (1985) confirmaram o diagnóstico de Brucellas ovis através da sorologia em 3 carneiros no Canadá após observarem sinais clínicos de hipertrofia epididimal e sêmen de má qualidade.

Quispe, Rivera e Rosadio (2002) relataram que o meio mais seguro de diagnosticar a enfermidade é o exame sorológico, pois em lote de machos onde $58,7 \%$ eram positivos a Brucella ovis, nenhum animal apresentava sintomas clínicos testiculares a palpação, no entanto a presença de sinais clínicos surgiu em 13,2\% (33/250) dos machos aos 30 dias de estação de monta, evoluindo pra 28,4\% (71/250) no final da mesma. Robles et al. (1998) observaram que de 78 reprodutores sororeagentes a Brucella ovis, apenas 22 apresentavam sinais clínicos de epididimite, assim como Kott et al. (1988) que concluíram que os ovinos podem carrear e eliminar a bactéria muito tempo antes de apresentar lesões palpáveis no aparelho reprodutor.

Ficapal et al. (1998) estudaram a relação entre o diagnóstico sorológico, bacteriano e clínico em 110 ovinos e observaram; 50,9\% de animais sororeagentes, $30,9 \%$ sororeagentes e com lesões testiculares macroscópicas, 20,9\% soronegativos e com lesões testiculares macroscópicas e $23,6 \%$ de isolamentos bacterianos mostrando que grande parte dos animais sororeagentes não excretam a bactéria no sêmen.

\subsection{Leptospirose}

O gênero Leptospira é representado por bactérias Gram-negativas flexuosas, helicoidais medindo 0,1 x 150-600 mM. As cepas são obrigatoriamente aeróbias e crescem em temperaturas de 28 a $30{ }^{\circ} \mathrm{C}$ em meios contendo vitaminas, albumina e soro de coelho e bovino. Algumas são patogênicos para animais e seres humanos, enquanto outras não. Estão presentes no solo, água doce ou ambientes marinhos (HOOKEY, 1991). 
A leptospirose ovina é uma infecção cosmopolita e está estreitamente vinculada aos fatores ambientais, embora sua incidência seja reduzida, a expansão é um fato real e crescente, sendo agravado em propriedades que adotam atividades consorciadas com outras espécies animais (LANGONI et al., 1995).

O primeiro relato da doença ocorreu na antiga URSS em 1935, quando Leptospira grippotyphosa foi isolada de bezerros com infecção aguda. Em ovinos foi relatada em 1937 na Áustria (RAFYI; MAGHAMI; NIAK, 1967) e desde então vários sorovares foram descritos em todo o mundo. Atualmente as leptospiras patogênicas são divididas em 13 espécies de leptospiras: L. alexanderi, L. alstonii, L. borgpetersenii, L. inadai, L. interrogans, L. fainei, L. kirschneri, L. licerasiae, L.noguchi, L. santarosai, L. terpstrae, L. weilii e L.wolffii, distribuídas em mais de 260 sorovariedades agrupadas em 23 sorogrupos (ABDOLLAHPOUR, 2010; ADLER; DE LA PEÑA MOCTEZUMA, 2010).

A primeira investigação no Brasil em ovinos foi realizada por Santa Rosa e Castro no ano de 1963 no estado de São Paulo constatando 34\% (136/400) de animais sororeativos, os sorovares observados dispostos de forma decrescente foram: canicola, pomona, icterohaemorrhagiae, serjoe, grippotyphosa, hyos e bataviae com títulos que variaram de 1:200 a 1:1600, posteriormente Santa Rosa et al. (1969/1970) em estudo retrospectivo encontraram 29,7\% de ovinos positivos, repetindo a ordem dos quatro sorovares principais observados no estudo anterior.

Viegas, Viegas e Caldas (1980) obtiveram 22,8\% no estado da Bahia, com predomínio dos sorovares autumanlis e castelloni, após quatorze anos o mesmo autor observou grande aumento da freqüência de leptospiras no estado com freqüência de $89,5 \%$ de ovinos soropositivos (VIEGAS et al., 1994). Também na Bahia, Caldas et al. (1983), obtiveram de 1.130 ovinos, $15,4 \%$ de animais sororeagentes sendo $23,8 \%$ de reações positivas para o sorovar autumnalis, $20,1 \%$ castellonis e $11,2 \%$ pomona. O grupo de pesquisas de Caldas possui resultados variados de outras investigações no mesmo estado com freqüências de ovinos sororeagentes nos anos de 1986, 1989, 1991, 1993 1995/96 e 1997/98 respectivamente de $34,7 \%(n=800), 11,72 \%(n=900), 46 \%(n=200), 71,5 \% \quad(n=111)$, $76,6 \%$ ( $n=103), 78,7 \%$ ( $n=122)$ (MELO et al., 2010).

No estado de São Paulo Langoni et al. (1995) encontraram pela prova de macroaglutinação em placa $41,92 \%$ e por aglutinação macroscópica $44,94 \%$ de 
sororeagentes. Dentre os sorovares estavam icterohaemorrhagie $(51,25 \%)$, castellonis $(20,63 \%)$, hardjo $(19,38 \%)$, bratislava $(16,25 \%)$, andamana e wolffi $(11,88 \%)$, copenhageni $(8,75 \%)$, grippothyphosa $(4,38 \%)$, pomona $(2,5 \%)$ e tarassovi $(0,63 \%)$. Favero et al. (2002) no mesmo estado encontraram apenas $0,7 \%(2 / 284)$ de animais sororeagentes, enquanto Escócio et al. (2008) obtiveram 50\% (29/58) em ovinos oriundos de rebanhos criados consorciados a bovinos e 40,4\% (21/52) em ovinos de criatórios exclusivos da espécie.

No Rio Grande do Sul, Herrmann et al. (2004) dentre 1.360 ovinos observaram $34,26 \%$ de positivos, com animais reativos para os seguintes sorovares: 210 hardjo, 152 sentot, 133 hardjoprajitno, 73 fortbragg, 39 wolffi, 25 pyrogenes, 21 australis, 20 pomona, 19 serjoe, 18 castellonis, 17 hebdomadis, 16 icterohaemorrhagiae, 9 grippotyphosa, 8 canicola, 7 tarassovi, 4 bratislava e 3 autumnalis.

Azevedo et al. (2004a) isolaram Leptospira spp. em rins de ovinos na Paraíba e obtiveram 3,5\% de ovinos sororeagentes em pesquisa realizada no estado do Rio Grande do Norte (AZEVEDO et al., 2004b). Silva et al. (2007) relataram que de 44 animais oriundos de matadouro de Pelotas, 20,9\% eram sororeagentes e ocorreu o primeiro isolamento de Leptospira noguchii em ovinos, através de amostra de rins de animal aparentemente saudável. Lilenbaum et al. (2009) no estado do Rio de Janeiro encontraram $13,7 \%$ de sororeagentes.

Mesmo em países tradicionais na criação de ovinos a leptospirose está presente, na Austrália de 2.160 ovinos, $42 \%$ apresentaram reatividade a leptospiras (ELLIS, 1994).

O sorovar hardjo é o mais freqüente em todo o mundo, portanto o maior causador de problemas reprodutivos em ovelhas e morte de cordeiros, sendo isolado em casos de abortamentos (HATHAWAY; MARSHALL, 1979; BAHAMAN et al., 1980; SCHMITZ; COLES; SHIRES, 1981; BLACKMORE; BAHAMAN; MARSHALL, 1982; ELLIS et al., 1983; KRAWCZYK, 2005; LILENBAUM et al., 2009; MELO et al., 2010).

São descritos outros sorovares associados a problemas reprodutivos, porém com menor freqüência, destacando-se os sorovares pomona, ballum, bratislava e grippotyphosa (BLACKMORE; BAHAMAN; MARSHALL, 1982; ELLIS et al., 1983). Evidências clínicas de leptospiras em ovinos são associadas à infecção pelos 
sorovares: pomona (HARTLEY, 1952; SULLIVAN, 1974; DAVISON; HIRSCH, 1980; LEON-VIZCAINO; HERDOSO DE MENDOZA; GARRIDO, 1987) grippotyphosa (LEON-VIZCAINO; HERDOSO DE MENDOZA; GARRIDO, 1987; OZDEMIR; EROL, 2002), ballum, icterohaemorrhagie e sejroe (LEON-VIZCAINO; HERDOSO DE MENDOZA; GARRIDO, 1987) e hardjo (ELLIS et al., 1983; McKEOWN; ELLIS, 1986). Podem ser observados diferentes sorovares de leptospiras no mesmo ovino (BLACKMORE; BAHAMAN; MARSHALL, 1982; HAJI HAJIKOLAEI, 2007). Em 2010 foi relatada a detecção do sorovar wolffii em ovinos, cães e humanos sendo considerada uma potencial nova espécie patogênica de leptospira (ZAKERI et al., 2010).

A transmissão pode ocorrer sempre que houver risco de contato direto ou indireto com urina de animais infectados e condições ótimas para a sobrevivência das leptospiras como ambiente quente e úmido. Devido à importância da água como meio de propagação da infecção, casos novos são mais prováveis de ocorrer em períodos chuvosos e regiões onde ocorre acúmulo de água (ABDOLLAHPOUR, 2010).

Outras formas de transmissão são o contato direto ou indireto com fluidos vaginais, placenta infectada, contato sexual ou infecção intra-uterina (MELO et al., 2010). Lilenbaum et al. (2008) sugeriram a transmissão via sêmen após detectarem o DNA leptospiral em amostras de 6 carneiros, no entanto os autores não descartam a possibilidade de o DNA encontrado na amostra ser resultado de contaminação da urina presente na uretra.

Cordeiros podem adquirir a infecção ingerindo leite ou colostro de vacas infectadas pela bactéria e desenvolver quadro clínico de anemia aguda, febre, depressão e dificuldade respiratória seguida de morte (WINTER, 1989; ELLIS et al., 1994).

Dentre os ruminantes domésticos, os ovinos são os que apresentam menor susceptibilidade a infecção (LEON-VIZCAINO; HERDOSO DE MENDOZA; GARRIDO, 1987; CICERONI et al., 2000), estudo realizado na Guiana comparando a infecção em rebanhos ovinos e bovinos demonstrou porcentagens de animais sororeagentes de $5,6 \%$ e $56,7 \%$ respectivamente (MOTIE; MYERS, 1986). Na Turquia, Ozdemir e Erol (2002) obtiveram $8 \%$ de ovinos e $45 \%$ de bovinos e 
Bahaman, Ibrahim e Adam (1987) na Malásia obtiveram 10\% de ovinos, $30 \%$ de bubalinos e $40,5 \%$ de bovinos sororeagentes.

Ovinos não parecem ser reservatórios primários das leptospiras, porém adquirem a infecção de ambientes contaminados pela urina de roedores e outros animais infectados tornando-se portadores assintomáticos, abrigando as leptospiras nos túbulos renais por extensos períodos e disseminando-as no meio ambiente (CICERONI et al., 2000; LEVETT, 2001).

Hathaway, Wilesmith e Little (1984) demonstraram que quanto maior a densidade de bovinos em uma propriedade, maior será a prevalência de ovinos infectados por Leptospira interrogans sorovar hardjo, pois os mesmos agem mantendo e eliminando esse sorovar no rebanho. No entanto no estudo de Cousins et al. (1989) foi observado alta incidência de ovinos sororeagentes ao sorovar hardjo, sendo que os mesmos nunca tiveram contato com bovinos, sugerindo assim a ocorrência de transmissão ativa entre os ovinos.

Os portadores assintomáticos ovinos desenvolvem infecção renal crônica (GERRITSEN; KOOPMANS; OLYHOEK, 1994) com leptospirúria persistente mantendo a infecção no rebanho com grande potencial zoonótico (COUSINS et al., 1989; LEVETT, 2001). A leptospirúria pode durar pelo menos 2 meses (GORDON, 1980). Sugere-se, no caso de machos com leptospirúria, que leptospiras presentes na uretra podem contaminar o sêmen no momento do coito, ocorrendo assim transmissão venérea, que pode se dar também devido à presença de leptospiras nos testículos e epidídimos (SMITH; REYNOLDS; CLARK, 1965).

Schmitz, Coles e Shires (1981) relataram doença hemolítica fatal em cordeiros que se encontravam em pastagens com áreas de alagadiços, sugerindo que esse seria o fator preponderante para manutenção e a transmissão de leptospiras entre os ovinos.

Os informes epidemiológicos indicaram a ocorrência de abortamentos e infertilidade principalmente nos criatórios com maiores taxas de prevalência. Lilenbaum et al. (2008) estudaram 3 rebanhos no estado do Rio de Janeiro que apresentavam mais de $30 \%$ de animais sororeagentes a leptospiras e com histórico de repetição de cio com conseqüente baixo índice de parição, partos prematuros e abortos esporádicos, foram analisadas 40 amostras de urina e obtido 2 isolamentos e 6 detecções pela PCR, que também detectou leptospiras em 6 amostras de sêmen 
de 14 reprodutores e 3 em muco vaginal de 3 fêmeas pertencentes aos rebanhos pesquisados, além disso, no muco vaginal de uma das fêmeas foi possível a observação de espiroquetas através da microscopia de campo escuro, sugerindo a transmissão venérea da leptospirose nos ovinos.

Em inoculações experimentais de ovinos prenhes as leptospiras foram isoladas de placenta, carúncula, cotilédone, líquido amniótico e alantoideano, sangue, conteúdo estomacal e órgãos fetais como fígado, pulmão e rins (SMITH; REYNOLDS; CLARK, 1962; SMITH; HENCH; REYNOLDS, 1966; SMITH; REYNOLDS; CLARK, 1966). Fêmeas prenhes ou lactantes quando infectadas naturalmente podem apresentar perdas reprodutivas ou agalactia, que resulta em perda de borregos por falta de leite (ELLIS, 1994, LANGONI et al., 1995; CICERONI et al., 2000).

A leptospirose pode manifestar-se de forma aguda, crônica ou inaparente, caracterizada por quadros clínicos de pirexia, icterícia, hemoglobinúria, leptospiremia, mastite sanguinolenta, abortamento seguida por hemorragia, nefrite, septicemia e anemia hemolítica nos cordeiros com morte na primeira semana de vida (HODGES, 1974; ANDREANI; TOLARI; FARINA, 1983; ACHA; SZYFRES, 1989). Entretanto, os sinais clínicos parecem diferir de uma região para outra, sempre na dependência do sorotipo, virulência, carga de inóculo, susceptibilidade, condição física e idade do animal (SMITH; REYNOLDS; SATAKI, 1960a; SMITH; REYNOLDS; CLARK, 1962; GUIDELINES, 1982).

Os achados post morten mais freqüentes são: severa icterícia dos órgãos, congestão ou hemorragia renal com presença de petéquias no córtex, congestão e icterícia hepática e sangue hemodiluído (SMITH; REYNOLDS; SATAKI, 1960b; SMITH; REYNOLDS; CLARK, 1962; SCHMITZ; COLES; SHIRES, 1981).

Os abortamentos ocorrem geralmente no terço final de gestação principalmente nas duas últimas semanas e tem sido observado o aumento do número de fetos mumificados, natimortos e cordeiros fracos ao nascer devido a infecções por leptospira de vários sorovares, em especial o hardjo (SMITH; REYNOLDS; CLARK, 1966; ELLIS, 1994; GERRITSEN; KOOPMANS; OLYHOEK, 1994).

Abortamentos causados por leptosiras apresentam fetos com lesões ictéricas e petéquias no tecido conjuntivo principalmente o subcutâneo, acúmulo de líquido 
sero-hemorrágico na cavidade abdominal e torácica, congestão generalizada em vísceras e fígado aumentado de coloração vermelho amarelado (LEON-VIZCANO et al., 1987; MELO et al., 2010).

Através da imunohistoquímica Saglam et al. (2008) observaram leptospiras em rins, pulmão, fígado e baço de $17 \%$ dos fetos ovinos abortados na Turquia. Leon-Vizcano et al. (1987) estudaram 973 fetos ovinos abortados, sendo que 17 $(1,7 \%)$ desses abortamentos foram causados por leptospiras.

Pode-se detectar títulos de leptospiras em fluídos das cavidades fetais pela técnica de aglutinação microscópica, no entanto essa técnica isoladamente não é suficiente para apontarmos a mesma como 0 agente etiológico do aborto (KIRKBRIDE; JOHNSON, 1989; CLARK, 1994).

A leptospirose pode causar mortalidade em cordeiros, assim como descrito em dois rebanhos na Austrália em 1980 que apresentaram morte súbita de cordeiros e alta soropositividade em ovinos e bovinos adultos criados juntos, sendo o principal sorovar o hardjo. (GORDON, 1980; McCAUGHAN et al., 1980). Davison e Hirsch (1980) relataram que cordeiros infectados pelo sorovar pomona apresentaram doença hemolítica aguda associada à alta mortalidade, severa depressão, febre, dispnéia e taquicardia. Os mesmos sinais clínicos, associado de hematúria e severa anemia, foram observados por Smith e Armstrong (1975) em casos de morte de cordeiros devido anemia hemolítica aguda, causada pelo mesmo sorovar nos E.U.A. Macroscopicamente os rins estavam hiperplásicos, friáveis, de coloração marrom com inúmeras estrias marrom escuro e pontos brancos espalhados ao longo do córtex renal.

\subsection{Campilobacter}

Campilobacter são bactérias Gram-negativas, microaerófilas, com aspecto de espiral da família Campylobacteriaceae. Campylobacter jejuni (anteriormente conhecido como Campylobacter fetus subespécie jejunı) e Campylobacter coli são associados à enterite em animais domésticos e seres humanos. Algumas cepas de Campylobacter jejuni, Campylobacter fetus subespécie venerealis e Campylobacter 
fetus subespécie fetus (também conhecido como Campylobacter fetus subespécie intestinalis e Vibrio fetus var intestinalis) podem causar infertilidade e abortos em ovinos e bovinos. Outras espécies de campilobacter incluindo Campylobacter lari, Campylobacter hyointestinalis e Campylobacter upsaliensis podem causar doenças, mas parecem ser de menor importância em animais domésticos (OIE, 2005).

Campylobacter jejuni, Campylobacter coli e Campylobacter fetus subespécie fetus são encontrados em todo o mundo e são as principais espécies capazes de causar problemas reprodutivos nos ovinos. (DIKER; ISTANBULLUOGLU, 1986; HEDSTROM et al., 1987; DIKER; SAHAL; AYDIN, 1988; PENNER, 1988; OIE, 2005; SAHIN et al., 2008). Podem ser encontrado em vários ambientes como solo, água e alimentos, provavelmente conseqüência do contato com fontes contaminantes como fezes de animais e produtos de abortamentos (BROMAN et al., 2002).

Scarcelli et al. (1998) em 69 ovinos, do Estado de São Paulo, encontraram dois $(2,9 \%)$ positivos para Campylobacter jejuni. No Brasil, há dois relatos do isolamento e identificação molecular (PCR) em feto ovino provenientes do Rio Grande do Sul. Vargas et al. (2005), isolaram e identificaram Campylobacter jejuni de feto abortado no terço final de gestação de criatório ovino da raça Texel com casos de abortamentos enquanto, Gressler et al. (2008) identificaram Campylobacter fetus subespécie fetus em 2 fetos lle de France abortados com 150 dias de gestação e sem lesões macroscópicas detectáveis.

O Campilobacter é a principal causa de abortamento em ovinos na Nova Zelândia, exemplo disso é o relato de quatro propriedades com média de abortamento de $2,8 \%$ a $9 \%$, onde se obteve 100 amostras de fetos abortados, sendo que em $77 \%$ foi isolado Campylobacter fetus subespécie fetus (BIRD et al., 1984). Em 126 fetos abortados na região de Hawkes Bay, no período de 1979 e 1980, foram isolados Campylobacter spp. em 63,5\% das amostras (QUINLIVAN; JOOP, 1982). Em estudo de amostras de abortamentos colhidos durante o ano de 2000 no mesmo país, Mannering et al. (2004) isolaram em 294 amostras Campylobacter fetus subespécie fetus de 200 fazendas e Mannering et al. (2006) isolaram em 25 amostras Campylobacter jejuni provenientes de 22 fazendas Neozelandesas, demonstrando com isso grande disseminação da bactéria no país.

Rebanhos neozelandeses mesmo vacinados apresentaram casos de abortamento por campilobacter, mostrando que a cobertura vacinal é ineficiente 
contra todas as cepas capazes de causar aborto (FENWICK et al., 2000). Collins e Lisle (1984) observaram 7 cepas diferentes de Campylobacter fetus subespécie fetus nos 51 fetos onde ocorreram isolamento do mesmo na Nova Zelândia, assim como Delong, Jaworski e Ward (1996), que observaram grande heterogeneidade entre as amostras isoladas de abortamentos ocorridos nos E.U.A.

De 27 produtores rurais dos Estados Unidos onde foram colhidos materiais de abortamentos de ovinos, campilobacter foi isolado em 14 propriedades, sendo que Campylobacter jejuni foi isolado em 13 delas e Campylobacter fetus subespécie fetus em apenas uma (DELONG; JAWORSKI; WARD, 1996).

Entre 2003 e 2007 o campilobacter foi isolado em 33 rebanhos ovinos de lowa, E.U.A., e esteve presentes em 25,2\% das amostras de abortamento colhidos no mesmo período, esses isolados eram compostos por $89 \%$ de Campylobacter jejuni e 11\% de Campylobacter fetus subespécie fetus (SAHIN et al., 2008).

Campylobacter fetus subespécie fetus foi uma das bactérias isoladas em casos de abortamentos em ovinos na Dinamarca (AGERHOLM et al., 2006) e relatado na Suécia como responsável por numerosos abortamentos em 2 rebanhos, após 0 isolarem em membranas fetais e amostras fecais (GUNNARSSON; HURVELL; MOLLERBERG, 1976).

Os isolamentos podem ocorrer em amostras de fígado, bile, bexiga, rúmen, intestino delgado e grosso, fezes, secreção vaginal, placenta, carúnculas, órgãos e conteúdo estomacal fetal (MONSBOURGH, 1979; HEDSTROM et al., 1987; STANLEY et al., 1998; RAJl et at., 2000; CAMPERO et al., 2005; CLARK; CORNELIUS; NICOL; HUDSON, 2005; VARGAS et al., 2005; MANNERING et al., 2006).

Açik e Çetinkaya (2006) identificaram campilobacter em 49,5\% de 610 amostras de bile, conteúdo intestinal e fezes de ovinos saudáveis, demonstrando que os mesmos podem agir como reservatório da bactéria, assim como Sproston et al. (2010) na Escócia, que o isolaram em 14 (30/214) das amostras fecais ovinas analisadas, sendo que foram observadas 9 cepas diferentes e a espécie mais prevalente foi Campylobacter coli, contrapondo Oporto et al. (2007) nos Países Bascos que observaram maior incidência de Campylobacter jejuni (28,3\%) nos 55\% $(66 / 120)$ de amostras isoladas. 
Diker, Esendal e Akan (2000) observaram que espécies animais, como aves e bovinos, quando presente em rebanhos ovinos, podem servir de reservatório de cepas de campilobacter capazes de causar abortos, devido suas similaridades.

A presença de aves nos criatórios ovinos aumenta o risco da doença (DENNIS, 1967; BROMAN et al., 2002), podendo contaminar cordeiros em seus primeiros dias de vida. Em rebanhos fechados há possibilidade de dispersão do campilobacter e contaminação através de fezes de aves predadoras que se alimentem de material de abortamento contaminado, assim como sugeriu Dennis (1967).

Ovinos de todas as faixas etárias podem se contaminar através da ingestão de pastos, cochos e águas contaminadas por fezes de animais adultos que eliminam a bactéria de forma intermitente, eliminação essa que pode variar devido a condições de estresse, temperatura e alimentação, demonstrando certa sazonalidade (STANLEY; JONES, 2003). Cordeiros podem se contaminar pelas fezes das mães de um a cinco dias após o nascimento (JONES; HOWARD; WALLACE, 1999).

Moscas, em propriedades de bovinos e ovinos que eliminem a bactéria nas fezes, podem agir como vetor contaminando água e alimentos apesar da baixa carga bacteriana transportada por elas (SPROSTON et al., 2010).

Jones, Howard e Wallace (1999) estudaram se a eliminação de campilobacter por ovinos nas pastagens ocorre de forma intermitente, pois segundo Stanley et al. (1998) $91,7 \%$ dos cordeiros abatidos no Reino Unido possuíam a bactéria em seu intestino delgado e rúmen em amostras analisadas mensalmente durante 1 ano (88,2\% de Campylobacter jejuni, 10,8\%, de Campylobacter coli, 0,8\% de Campylobacter hyointestinalis e $0,2 \%$ de Campylobacter lari). $O$ estudo de Jones, Howard e Wallace (1999) foi realizado durante 12 meses em rebanhos com 3 tipos diferentes de alimentação. Foi observado que a eliminação de campilobacter durante o ano em média, foi próxima a $1 / 3$ da taxa de transporte intestinal e que em alguns meses onde foi fornecido alimento de melhor qualidade, feno e silagem, as taxa de eliminação chegaram a $0 \%$, enquanto outros onde ocorreram situações de estresse, como parto, desmame e mudança de pasto, as taxas em sistemas de alimentação de menor qualidade chegaram a $100 \%$, além de fêmeas que não eliminavam ou eliminavam em baixas concentrações a bactéria pré-parto, passaram a eliminar e 
aumentaram a concentração da mesma nas fezes. Dentre as espécies isoladas o Campylobacter jejuni foi responsável por 90\%, sobrevivendo até 4 dias nas fezes, enquanto o Campylobacter coli e Campylobacter lari foram responsáveis por $8 \%$ e $2 \%$ respectivamente (JONES, HOWARD; WALLACE, 1999).

O contato com produtos de abortamento como, descargas vaginais, fetos e membranas fetais que contaminam água, pasto e alimento é outro importante meio de transmissão entre os ovinos (DENNIS, 1967).

Infecção oral por alta carga do agente leva à rápida bacteremia, que não dura mais que 72 horas, sendo disseminado para os linfonodos mesentéricos, trato gastrointestinal, vesícula biliar e baço (WALT, 1994) até atingir o útero grávido, especialmente nos estágios finais da gestação. Após incubação, que pode levar dois meses, provoca placentite que progride para infecção do feto (fluido amniótico) e posteriormente aborto (HIRSH, 1999).

A campilobacteriose em ovinos é caracterizada por abortamento no terço final de gestação, natimortalidade, nascimentos de cordeiros prematuros, fracos, ocasionalmente morte de fêmeas decorrente a metrite (DENNIS, 1975; HEDSTROM et al., 1987; HIRSH, 1999) e cordeiros por diarréia e/ou gastroenterite (STANSFIELD et al., 1986; ANDRÉS et al., 2007). Muitas ovelhas apresentam diarréia antes do primeiro episódio de abortamento fato que acorre em cerca de $10 \%$ do rebanho (WALT, 1994).

Fêmeas inoculadas artificialmente apresentaram abortamento em 100\% dos casos e sinais clínicos semelhantes aos casos de infecção natural, caracterizados por endometrite purulenta e placentite necropurulenta, com cotilédones amareladas e carúnculas edemaciadas com estrias hemorrágicas, coberta por exsudato mucoserosanguinolento e fribrinoso. (HEDSTROM et al., 1987; HIRSH, 1999).

A placenta pode se apresentar edemaciada, com placentite focal ou generalizada hiperemia difusa e cotilédones friáveis, edemaciados, com coloração de rosa a amarela e lesões principalmente em sua periferia (DENNIS, 1975; FENWICK et al., 2000)

Quanto aos fetos abortados são observados diferentes graus de autólise, edema subcutâneo, presença de líquido sero-sanguinolento no abdômen e tórax e necrose hepática multifocal (HEDSTROM et al., 1987; KIRKBRIDE, 1993; FENWICK et al., 2000; SAHIN et al., 2008). Segundo Quinn et al. (2005), lesões necróticas 
circulares de dois centímetros de diâmetros, com bordas elevadas e claras, de centros deprimidos e escuros são evidentes na superfície do fígado de alguns cordeiros abortados, sendo estas lesões hepáticas, patognomônicas de campilobacteriose ovina.

Dennis (1975), necropsiou 91 cordeiros infectados por Campylobacter fetus subespécie intestinalis (Campylobacter fetus subespécie fetus), resultado de 48 surtos de aborto ocorrido no oeste da Austrália entre 1963 a 1965, dentre as lesões mais observadas estavam; edema subcutâneo $(58,2 \%)$, presença excessiva de líquido seroso na cavidade abdominal e torácica $(80,2 \%)$, lesões necróticas hepáticas focais tipo "roseta" (37,4\%), conteúdo abomasal normalmente avermelhado, mucoso e floculado. Desses cordeiros estudados, 50,5\% foram abortados, $13,2 \%$ eram natimortos e $36,3 \%$ decorrente de morte neonatal.

Pesquisa realizada com 1.784 fetos ovinos abortados durante 10 anos em Dakota do Sul, E.U.A., demonstrou prevalência de 10,3\% (184) de campilobacter, sendo 7\% (125) Campylobacter fetus, 3,2\% (57) Campylobacter jejuni e 0,1\% (2) Campylobacter spp., a maioria dos abortamentos ocorreram na segunda metade da gestação apresentando autólise de ligeira a moderada e como lesões fetais mais encontradas a peritonite fibrinosa seguida de pneumonia de gravidade variada (KIRKBRIDE, 1993).

São escassos os estudos da influência do campilobacter na qualidade do sêmen ovino, Zan Bar et al. (2008) inocularam Campylobacter fetus subespécie fetus e observaram as seguintes alterações em relação ao grupo controle do estudo após 5 horas de incubação do sêmen ovino com a bactéria; diminuição da motilidade, vigor espermático e aumento da expressão de receptores FAS na superfície das células espermáticas (FasR). Quanto à morfologia, maior presença de defeitos de acrossomo, cabeça solta, aglutinação de cabeça e cauda dobrada, sugerindo que essa espécie de campilobacter possa ser tóxica às células espermáticas

Nos casos de surtos de abortamentos por campilobacter a vacinação irá reduzir o número de casos e irá prevenir abortamentos nas próximas gestações. A vacinação preventiva em animais saudáveis é recomendada no início do terço final da gestação (GILMOUR; THOMPSON; FRESER, 1975; GUMBRELL; SAVILLET; GRAHAM, 1996). 


\subsection{Histophilus somni}

Histophilus somni é uma bactéria Gram-negativa, fastidiosa e de patogenia facultativa. Na literatura foram utilizadas diferentes nomenclaturas em paralelo para a bactéria (Histophilus ovis, Haemophilus agni, Haemophilus somnus), pois durante longo período sua posição taxonômica não foi esclarecida, até que Angen et al. (2003) sugeriram o nome Histophilus somni, pois concluíram que os utilizados anteriormente estavam relacionados ao mesmo microorganismo. Foi isolada pela primeira vez em 1956 em bovino com quadro de encefalite, é um patógeno oportunista que habita o trato respiratório superior e trato genital (HARRIS; JANZEN, 1989) causando nos bovinos meningoencefalite tromboembólica (KENNEDY et al., 1960), pneumonia (ANDREWS et al., 1985), metrite (MILLER; BARNUM; McENTEE, 1983) e aborto (VAN DREUMEL; KIERSTEAD, 1975). Nos caprinos, o primeiro isolamento se deu em 2009 na Hungria, em amostras de zaragatoa vaginal de rebanhos que estavam em estação de monta e que tinham contato direto com ovinos (JÁNOSI et al., 2009). Em 1956 ocorreu o primeiro relato em fêmea ovina com quadro de mastite (ROBERTS, 1956).

Rahaley e Edwards (1983) concluíram que Histophilus somni não constitui a flora vaginal normal de ovinos, pois não obtiveram nenhum isolamento em fêmeas sadias, enquanto Erasmus (1983) a isolou no trato genital de carneiros saudáveis. Walker e LeaMaster (1986) em seu estudo observaram que Histophilus somni é um organismo transitório da flora vaginal ovina, pois o isolou em $100 \%$ de fêmeas saudáveis com seis meses de vida e em 16\% com idade acima de dois anos. Gregory et al. (2010) isolaram a bactéria de ovelha com quadro de endometrite apresentando secreção uterina de quantidade moderada, coloração esbranquiçada, aspecto mucoso e odor fétido. Nota-se pelos trabalhos acima citados que existem opiniões controversas sobre a ocorrência da bactéria no trato reprodutivo de ovinos e sua patogenicidade.

Histophilus somni foi isolado em rebanhos Irlandeses com casos de vulvite, sendo que essas cepas isoladas foram utilizadas para inoculação experimental via vaginal causando quadro semelhante observado nos animais inoculados naturalmente (BALL; KENNEDY; ELLIS, 1991). A bactéria também é associada a 
casos de morte neonatal e retenção de placenta na Austrália (RAHALEY; WHITE, 1977) e isolado de vagina de ovelhas com quadro de metrite (HIGGINS et al., 1981)

Além disso, em ovinos, a doença pode causar casos de septicemia (KENNEDY et al., 1960), meningite (LEES; YATES; CORBEIL, 1994), mastite (ROBERTS, 1956), polisinovite, perdas neonatais (RAHALEY; WHITE, 1977), aborto (HAJTÓS, 1987), vulvite (BALL; KENNEDY; ELLIS, 1991) e epididimite em carneiros jovens (LOW; GRAHAM, 1985; SAUNDERS et al., 2007).

\subsection{Neospora caninum}

A neosporose é uma doença reprodutiva, infecciosa, causada pelo parasita Neospora caninum que provoca casos de abortamentos e mortalidade neonatal em ruminantes (BARBER et al., 1997). Na América do Sul foi relatada em bovinos, bubalinos, ovinos, caprinos, alpacas, llamas, caninos domésticos e selvagens, felinos e gambá (MOORE, 2005).

O primeiro caso de neosporose em ovinos foi relatado por Dubey et al. (1990) que encontraram cistos teciduais de Neospora caninum no cérebro e medula espinal de cordeiro com suspeita de toxoplasmose, devido sinais neurológicos, que veio a óbito com uma semana de idade. Kobayashi et al. (2001) relataram o primeiro caso de infecção por Neospora caninum em ovino adulto assintomático, além de confirmarem a transmissão transplacentária em ovinos, pois cistos foram observados em dois fetos infectados verticalmente. Também em 2001, Koyama et al. isolaram o parasita de cérebro de ovelha prenhe, assintomática e sem histórico de abortamento.

No Brasil os levantamentos sorológicos de neosporose em ovinos são recentes. Figliuolo et al. (2004) em 597 ovinos criados no estado de São Paulo encontraram 5,9\% (7/118) de sororeagentes em animais com menos que um ano de idade, 9,2\% (17/185) com um a quatro anos e 10,5\% (31/284) em animais com mais de quatro anos, a prevalência variou de zero e $22,7 \%$ de animais positivos nas 30 propriedades estudadas. Otero et al. (2005) observaram, em ovinos de 10 propriedades baianas, 7,4\% (21/282) de animais sororeagentes, enquanto Aguiar et 
al. (2005) 29\% (41/141) em 9 das 15 propriedades de Roraima estudadas e Vogel, Arenhart e Bauermann (2006) 3,2\% (2/62) no Rio Grande do Sul. Romanelli et al. (2007) relataram $9,5 \%$ de animais positivos (29/305) em 9 das 8 propriedades estudadas no Paraná sendo que cinco possuíam canídeos sororeagentes. Rossi et al. (2008) observaram incidência mais elevada em relação aos outros estudos com $47 \%$ (73/155) de sororeagentes em dois rebanhos de Uberlândia, que individualmente apresentaram incidências distintas de 31,5\% (30/95) e 71,6\% (43/60) e Ueno et al. (2009) no Distrito Federal, encontraram 8,81\% (90/1028) em 28 das 32 propriedades com prevalência individual variando de zero a $27,78 \%$. Souza Neto et al. (2009) 10,1\% (16/158) no município de Gravatá-PE, enquanto Soares et al. (2009) em Mossoró-RN, relataram a menor prevalência entre os estudos nacionais com 1,8\% (7/409) de animais sororeagentes em $17,1 \%$ das propriedades e presença de cães em 73,4\% delas. Em Alagoas, Farias et al. (2009) obtiveram 9,6\% (33/343) de animais positivos para Neospora caninum, sendo que 53,8\% (14/26) das propriedades estudadas apresentam ao menos um animal positivo.

Em 2007 foi relatado o primeiro isolamento de Neospora caninum em ovinos naturalmente infectados no Brasil, a fêmea não apresentava sinais clínicos e era sororeagente (1:50) (PENA et al., 2007).

Nos rebanhos europeus os estudos demonstram baixa incidência da infecção (HELMICK et al., 2002; GAFFURI et al., 2006), sendo que alguns países como a República Checa somente em 2009 relataram a primeira evidência de infecção em seu rebanho com incidência de 12\% (63/547), desses animais, 83\% apresentaram reação mista para Toxoplasma gondii (BÁRTOVÁ; SEDLÁ; LITERÁ, 2009) que freqüentemente apresenta maior incidência nos rebanhos em relação ao Neospora caninum em estudos onde se pesquisa evidências dos dois parasitas (HÄSSIG et al., 2003; FIGLIUOLO et al., 2004; ROMANELLI et al., 2007; BÁRTOVÁ; SEDLÁ; LITERÁ, 2009; ŚPILOVSKÁ et at., 2009; UENO et al., 2009).

$\mathrm{Na}$ Itália, Gaffuri et al. (2006) observaram incidência de 2\% (22/1010) e Pandero et al. (2010) na Região da Galícia, Espanha, 10,1\% (18/177) em ovelhas saudáveis. A incidência de animais sororeagentes para Neospora caninum não foi alterada quando foram realizados estudos em rebanhos com histórico de problemas reprodutivos como abortamentos e/ou infertilidade. No Reino Unido observou-se 0,45\% (3/666) (HELMICK et al., 2002), Eslováquia com 3,7\% (14/382) (ŚPILOVSKÁ 
et al., 2009) e Suíça, 10,3\% (12/117) (HÄSSIG et al., 2003) de animais sororeagentes.

O principal meio de transmissão é a transplacentária (McALLISTER et al., 1998), ocorre também à transmissão oral através da ingestão de colostro (DAVISON et al., 2001) e de oocistos eliminados nas fezes de canídeos que se tornam seus hospedeiros definitivos após ingestão de tecidos infectados com cistos de Neospora caninum (McALLISTER et al., 1998; MOORE, 2005).

Vários estudos relatam que em ovinos não há associação entre idade, sexo e a infecção por Neospora caninum, como pode ocorrer no caso da infecção por Toxoplasma gondii (GARCIA et al., 1999; FIGLIUOLO et al., 2004; ROMANELLI et al., 2007; UENO et al., 2009).

Estudos de prevalência e análise de risco em ovinos, como realizados na Jordânia $(4,3 \%)$ e no Brasil no estado de Alagoas (9,6\%), mostram que pequenos criatórios ( $<30 \mathrm{ha}$ ), com pastagens em comuns, diversos tipos de fonte de água e presença de mais de um cão, possuem maior possibilidade de se diagnosticar animais sororeagentes para Neospora caninum (AL-MAJALI et al., 2008; FARIAS et al., 2009).

Quanto à presença de cães, estudo realizado com bovinos leiteiros relatou que para cada cão presente na propriedade rural, há aumento de 1,13 vezes da possibilidade dos bovinos se contaminarem (CORBELLINI et al., 2006), no entanto alguns autores não encontraram associação quanto à presença de cães e ovinos sororeagentes (FIGLIUOLO et al., 2004; ROMANELLI et al., 2007; SOARES et al., 2009; SOUZA NETO et al., 2009), sugerindo neste caso que a transmissão tenha sido preferencialmente vertical (FIGLIUOLO et al., 2004; ROMANELLI et al., 2007).

Outros fatores de riscos que podem causar diferentes prevalências são umidade e região estudada, pois em regiões com alta umidade os oocistos podem esporular e permanecer viáveis no ambiente por mais tempo (COBERLLINE et al., 2006).

O primeiro relato do agente em material de abortamento foi realizado por Hässig et al. (2003) que relataram quatro casos de aborto por Neospora caninum, confirmados pela PCR e presença de cistos no cérebro observado por imunohistoquímica, em rebanho Suíço com $10,3 \%$ de fêmeas sororeagentes a Neospora caninum e $97,4 \%$ para Toxoplasma gondii, confirmando o resultado de 
Innes et al. (2001) que mostraram não ocorrer proteção cruzada, nos casos de mortes fetais, entre os dois parasitas.

Em 2006 Neospora caninum foi descrito como o possível causador de abortos em 3 rebanhos de fêmeas nulíparas na Nova Zelândia, pois os animais que abortaram faziam parte dos $45,6 \%$ que apresentaram anticorpos contra Neospora caninum enquanto que dos animais que pariram normalmente apenas 5,6\% eram sororeagentes, além disso, 4 de 5 fetos abortados apresentaram sorologia positiva (WEST et al., 2006). Outros três rebanhos neozelandeses, vacinados contra Toxoplasma gondii e campilobacter, apresentaram casos de abortos relacionados ao parasita, confirmado após detecção do mesmo em sangue e placenta de fêmeas que abortaram e cérebro proveniente dos abortamentos, foi descartado a toxoplasmose e leptospirose como causadoras dos surtos (HOWE et al., 2008).

No entanto alguns autores consideram raros os casos de abortos causados por esse parasita (HELMICK et at., 2002) devido à baixa incidência nos rebanhos (BUXTON; MCALLISTER; DUBEY, 2002) e em pesquisa de abortamentos, como as realizadas por Otter et al. (1997) que não observaram presença de anticorpos contra Neospora caninum em 179 amostras de líquido pleural de fetos abortados na Inglaterra e País de Gales e Masala et al. (2007) na Itália que não identificou Neospora caninum pela PCR em 76 amostras de placentas proveniente de abortamento e em amostras fetais obteve êxito em apenas $2 \%(6 / 292)$ e destas somente duas amostras o parasita foi o único agente detectado.

Em geral, ovelhas experimentalmente infectadas, observa-se que quando as mesmas são inoculadas aos 2 meses de gestação apresentam aborto ou absorção fetal, aos 3 meses parem cordeiros débeis ou clinicamente normais e as inoculadas aos quatro meses cordeiros clinicamente sadios (DUBEY; LINDSAY, 1990; McALLISTER et al., 1996; BUXTON et al., 1998).

Em estudo de inoculação experimental realizado por Buxton et al. (2001) foi observado que ovelhas infectadas antes do período gestacional adquirem certa imunidade ao parasita. Os resultados obtidos foram que quando as fêmeas foram inoculadas previamente ao período gestacional não apresentaram casos de abortamento e pariram cordeiros infectados, fêmeas inoculadas previamente e aos 90 dias de gestação pariram cordeiros vivos $(n=9)$ e mortos $(n=6), 80 \%(6 / 8)$ dos 
vivos estudados não estavam infectados, e todas as fêmeas desafiadas aos 90 dias da gestação apresentaram casos de abortamentos.

Os abortamentos podem estar macerados ou mumificados (COSTARELLI et al., 2004). Infecção congênita de ovelhas cronicamente infectadas pode resultar em casos seqüenciais de aborto assim como relatado em bovinos (JOLLEY et al., 1999).

Fetos clinicamente sadios, débeis ou abortados podem apresentar cistos do protozoário no cérebro, encefalite multifocal não supurativa, necrose cerebral, mineralização distrófica, meningite ao exame histológico do sistema nervoso (McALLISTER et al., 1996; BUXTON et al., 1997, 1998; JOLLEY et al., 1999), nos fetos abortados é comum a presença de miosite não supurativa (McALLISTER et al., 1996).

No experimento de McAllister et al. (1996) foi observado à presença de placentite não supurativa necrosante em 88\% (15/17) das placentas examinadas, a placentite também foi observada por Buxton et al. $(1997,1998,2001)$ em ovinos experimentalmente infectados, além de aumento da temperatura corporal nos primeiros dez dias após a infecção e lesões no sistema nervoso central de fetos, como meningite não supurativa (BUXTON et al., 2001).

Romanelli et al. (2007) não observaram relação entre ovinos sororeagentes e animais que haviam apresentado problemas reprodutivos ou cordeiros com alterações neurológicas.

Como citado anteriormente à incidência de Neospora caninum, em rebanhos ovinos, em relação à de Toxoplasma gondii geralmente é menor e por isso quando analisamos a freqüência de animais sororeagentes as duas doenças parasitárias concomitantemente observamos baixa incidência como relatada por Figliuolo et al. (2004) com 3.5\% de 597 amostras, Romanelli et al. (2007) com 5.2\% de 305, Ueno et al. (2009) com 4.67\% de 1.028 e Pandero et al. (2010) com 9\% de 177 amostras.

\subsection{Toxoplasma gondii}

Uma das mais importantes enfermidades parasitárias reprodutiva no Brasil é a toxoplasmose cujo agente etiológico é o Toxoplasma gondii, (HOFF; 
CARRUTHERS, 2002). De modo geral, dentre os animais de produção, caprinos, ovinos e suínos são os mais sensíveis à infecção quando comparados a bovinos, eqüinos e aves que raramente vão apresentar alguma sintomatologia (MILLAR et al., 2008).

A toxoplasmose em ovinos é reconhecida como a maior causa de abortamentos dessa espécie desde 1951, quando estruturas semelhantes ao Toxoplasma gondii foram descritas, pela primeira vez, na placenta e fetos de ovelhas que abortaram na Nova Zelândia (HARTLEY; JEBSON; McFARLANE, 1954). Perdas devido à toxoplasmose ovina durante a gestação variam entre 1,4 a 3,9\% do rebanho, causando um prejuízo de 1,4 a 4,7 milhões de dólares (FREYRE et al., 1999).

A soroprevalência possui grande variação dependendo da região estudada (BLEWETT; WATSON, 1983). Inquéritos sorológicos realizados em ovinos revelam freqüências de infecções por Toxoplasma gondii que variam de zero a 92\% dependendo da região do mundo e do teste diagnóstico empregado (TENTER; HECKEROTH; WEISS, 2000).

Amaral, Santos e Rebouças (1978) encontraram 23\% de animais sororeagentes ao parasita em ovinos do estado do Rio Grande do Sul, Larsson et al. (1980) em animais oriundos do mesmo estado, obtiveram 39\% de animais sororeagentes, através da reação de Sabin-Feldman em 100 ovinos do município de Uruguaiana-RS.

No estado do Paraná existem estudos de prevalência de Toxoplasma gondii em ovinos realizado por Freire et al. (1995) em Londrina, que testaram 370 amostras e obtiveram $47,83 \%$ de sororeagentes, não observando diferença significante entre sexo e faixa etária, com valores de $36,84 \%, 48,55 \%, 47,37 \%$ e $48,31 \%$ para carneiros, ovelhas, cordeiros machos e fêmeas respectivamente. No mesmo município Ogawa et al. (2003) relataram 54\% (185/339) de ovinos sororeagentes com títulos variando de 64 a 65.536 e no norte do estado, Garcia et al. (1999) e Romanelli et al. (2007) encontraram 51,8\% (118/228) e 51,5\% (157/305) de soroprevalência, respectivamente. Moura et al. (2007) em ovinos destinados ao abate provenientes do município de Guarapuava relataram 7\% (11/157) de animais sororeagentes, essa baixa prevalência em relação aos outros estudos deve-se a amostragem ser composta por animais jovens que são preteridos pelos abatedouros. 
Por fim, Thomaz-Soccol et al. (2009) avaliaram a ocorrência da infecção pelo parasita em propriedades localizadas na região urbana e peri-urbana de Curitiba e encontraram $35,5 \% \quad(27 / 76)$ e $17,6 \% \quad(16 / 91)$ de animais sororeagentes respectivamente.

$\mathrm{Na}$ década de 90 Oliveira-Siqueira et al. (1993) encontraram no estado de São Paulo prevalência de $22,5 \%$, de ovinos infectados por Toxoplasma gondii, com o crescimento do rebanho paulista, na década seguinte surgiram outros estudos como de Meireles, Galisteo Junior e Andrade Junior (2003) que em ovinos criados extensivamente e destinados ao abate encontraram 31\% (62/200) de animais infectados. Figliuolo et al. (2004) investigaram a prevalência de anticorpos antiToxoplasma gondii em 597 ovinos constatando a presença em 16,1\% dos animais com menos de um ano de idade, $24,9 \%$ com um a quatro anos e $48,3 \%$ com mais de quatro anos. Na região de Sorocaba, Felicio et al. (2008) obtiveram 31,62\% (86/272) de animais sororeagentes e na Microrregião de Jaboticabal, Lopes et al. (2010) diagnosticaram em 488 ovinos $52 \%$ de sororeagentes.

Em 711 animais oriundos de rebanhos de oito Mesorregiões do estado de Minas Gerais, Carneiro (2006) obteve $43,2 \%$ de sororeagentes pela RIFI e titulação acima de 1:64, os resultados individuais de cada região foram: 2,5\% (18) em Campo das Vertentes, 1,5\% (11) em Central de Minas, 13,4\% (95) na Metropolitana de Belo Horizonte, 4,4\% (31) no Oeste de Minas, 19,3\% (137) no Sul/Sudeste de Minas, 20,3\% (144) no Triângulo/Alto do Paranaíba; $18,3 \%$ (130) no Vale do Rio Doce e $20,4 \%$ na Zona da Mata confirmando que a prevalência pode variar dependendo da região estudada mesmo dentro do mesmo estado. Em Uberlândia, os resultados de dois trabalhos de prevalência foram de $67,85 \%$ (76/112) e 46,4\% (72/155) de ovinos sororeagentes (ROSSI; CABRAL; CORRÊA, 2008; ROSSI et al., 2008).

$\mathrm{Na}$ região da Grande Vitória, Espírito Santo e Distrito Federal trabalhos mostram $38,5 \%(91 / 236)$ e $35,4 \%$ (364/1028) de ovinos infectados respectivamente (BARIONI et al., 2009; UENO et al., 2009).

Em relação a região Nordeste, há estudos de Pita Gondim et al. (1999) que observaram 18,75\% (45/240) de ovinos sororeagentes no estado da Bahia. Em Alagoas, Pinheiro Junior et al. (2009) obtiveram de 432 ovinos, 142 (32.9\%) sororeagentes. Em Pernambuco, dois estudos apresentaram prevalências distintas, Silva et al. (2003) encontraram 35,3\% de animais sororeagentes em 173 soros e não 
foi observada associação significativa a animais inférteis e Albuquerque et al. (2009) pesquisaram em 165 ovinos do município de Gravatá, e encontrou 39 (24\%) sororeagentes. No município de Lajes, no Rio Grande do Norte, Clementino, Souza e Andrade Neto (2007) relatam 29,41\% (30/102) de animais infectados, sendo que a incidência da infecção aumentou conforme a idade dos animais. No mesmo estado, em Mossoró, Soares et al. (2009) em 409 ovinos encontraram 20,7\% de animais sororeagentes. Em São Luiz no Maranhão a prevalência observada foi de $23 \%$ (37/161) (BRANDÃO et al., 2009). Na região Norte, Cavalcante et al. (2004) relataram prevalência de $46,8 \%$ de ovinos sororeagentes a toxoplasmose no estado de Rondônia.

Trabalhos em rebanhos nacionais relatam a presença de ao menos um ovino sororeagentes em todos os criatórios pesquisadas, com prevalência individual variando de 3,4\% a 96,55\% (OGAWA et al., 2003; FIGLIUOLO et al., 2004; ROMANELLI et al., 2007; ALBUQUERQUE et al., 2009; BARIONI et al., 2009; PINHEIRO JUNIOR et al., 2009; THOMAZ-SOCCOL et al., 2009; UENO et al., 2009; LOPES et al., 2010). Silva et al. (2003) observaram ovinos positivos em 9 de 10 criatórios de Pernambuco com prevalência variando entre 14,9\% e 90,9\%, Brandão et al. (2009) em 9 de 8 e Soares et al. (2009) em 23 de 35 (65,7\%) criatórios de Mossoró com freqüências de ovinos sororeagentes entre $4,7 \%$ a $88,8 \%$, demonstrando grande presença do parasita nos rebanhos brasileiros independente da região estudada.

Pesquisando a etiologia de casos de abortamentos na Itália, Massala et al. (2007) analisaram através da PCR, 292 fetos e 76 placentas ovinas, o Toxoplasma gondii foi o agente mais detectado nas amostras, estando presente em $53(18,1 \%)$ fetos e $10(13,1 \%)$ placentas. Em 16 amostras de fetos foram detectado outros agentes causadores de abortamento concomitantemente sendo eles Salmonella entérica sorovar abortusovis (5), Coxiella burnetii (4), Neospora caninum (3) e Chlamydophila abortus (1). Em duas amostras detectou-se além do parasita, Salmonella entérica sorovar abortusovis e Coxiella burnetii e em uma amostra todos os agentes citados com exceção do Neospora caninum. Quanto às amostras de placenta ocorreram associações com Chlamydophila abortus (2), Coxiella burnetii (1) e Neospora caninum (1), demonstrando grande diversidade etiológica e que 
somente a detecção não é suficiente para realizar o diagnóstico, principalmente quando a presença de mais de um agente.

$\mathrm{Na}$ Espanha em pesquisa com quatro diferentes técnicas para diagnosticar a toxoplasmose em fetos abortados, sendo elas a imunofluorescência indireta, ELISA, histologia e a PCR, observou-se 40 de 176 fetos positivos por uma ou mais das técnicas utilizadas (PEREIRA-BUENO et al., 2004).

Okuda et al. (2007) em criatórios de Minas Gerais encontraram sororeação positiva em 18 fêmeas que abortaram e em 4 fetos abortados por esses animais. Foram descritos encefalite não-purulenta com necrose multifocal, miocardite e hepatite não purulenta, necrose hepática difusa, além de infiltrado mononuclear pulmonar e renal. O parasita foi isolado em cultura de células, camundongos e identificado pela PCR.

É observada maior prevalência da infecção por Toxoplasma gondii em regiões úmidas, pois o clima e a vegetação contribuem para a formação de microambiente favorável a manutenção de oocistos viáveis no solo (PITA GONDIM et al., 1999; SILVA et al., 2003).

Os ovinos se infectam pelo Toxoplasma gondii através da ingestão de pasto e água contaminados por oocistos liberados juntamente com as fezes de gatos, 0 hospedeiro definitivo deste agente (LUNDEN; NASHOLM; UGGLA, 1994; ESTEBAN-REDONDO; INNES, 1997) que se infectam através da ingestão de carcaça de animais com cistos do parasita como relatado por Spósito Filha et al. (1992) que isolaram, em camundongos, 20 cepas de Toxoplasma gondi a partir de 136 músculos diafragmáticos de ovinos provenientes do estado do Rio Grande do Sul.

Altas porcentagens de ovinos sororeagentes ao Toxoplasma gondii podem estar relacionadas à contaminação do ambiente com o parasita, sendo explicado pela presença de gatos e roedores, no mesmo ambiente de convívio e pela preferência dos ovinos ao consumo de pastagens e gramíneas de porte baixo, o que favorece a possível ingestão de oocistos. Felinos presentes em propriedades rurais e relacionados ao controle de roedores têm fundamental importância na epidemiologia do Toxoplasma gondii, já que os oocistos eliminados nas fezes dos gatos podem, dependendo das condições ambientais, perdurarem por vários meses até anos no meio ambiente (FRENKEL; RUIZ; CHINCHILLA, 1975). Romanelli et al. 
(2007) observaram que o acesso de felinos ao depósito de alimentos é um fator significante para a infecção em ovinos $(\mathrm{OR}=1,95)$ e em 6 dos 9 criatórios de seu estudo havia a presença de felinos, sendo que a que possuía apenas um felino apresentou a menor prevalência (28\%) enquanto a que possuía mais de 20 felinos, mostrou-se com maior prevalência (84\%). Assim como Pinheiro Junior et al. (2009) e Lopes et al. (2010) que relataram que a presença de felinos aumenta de 1,72 a 2,83 o risco de infecção respectivamente.

No entanto alguns autores não observaram relação entre presença de felinos em propriedades de ovinos e animais positivos para Toxoplasma gondii, mas em alguns casos criatórios que possuíam felinos apresentavam incidência maior da infecção em relação aos que não possuíam (OGAWA et al., 2003; ALBUQUERQUE et al., 2009; BRANDÃO et al., 2009; SOARES et al., 2009). Para Figliuolo et al. (2004) não foi possível realizar essa análise, pois todos os criatórios estudados possuíam felinos.

Existe ainda a possibilidade de transmissão congênita, como descrita por Silva e De La Rue (2006) que em quatro cordeiros, cujas mães apresentaram títulos de IgG, seus títulos se elevaram da primeira colheita realizada no momento do nascimento para segunda após 3 meses. Destas quatro fêmeas sororeagentes, três foram IgM positivas, caracterizando a fase aguda da doença.

Mason, Quinnell e Smith (2010) utilizando cordão umbilical de cordeiros recém nascidos relataram detecção pela PCR em 6,2\% (14/226) de cordeiros da raça Charolês e $10,2 \%$ (24/236) em ovinos da raça Swaledale, no entanto foi observada menor prevalência na sorologia dos cordeiros da raça Swaledale após 4 meses com prevalência de $3 \%$ (7/236). Com esses dados, dos cordeiros da raça Swaledale, foram sugeridas as seguintes alternativas para tal soroconversão; falha do parasita em invadir os tecidos ou presença em baixa quantidade ou transitória do parasita no cordão umbilical. Quanto os cordeiros da raça Charolês ocorreu discreto aumento (10,6\%). A infecção vertical pode afetar até $66 \%$ dos cordeiros paridos por fêmeas infectadas (HIDE et al., 2009).

A transmissão via sêmen foi observada experimentalmente através de inseminação artificial utilizando sêmen frasco contendo taquizoítos onde em 28 de 30 fêmeas detectou-se o DNA do parasita no sangue pela PCR (MORAES et al., 
2010). Em machos experimentalmente infectados foi possível o isolamento pela bioprova e detecção pela PCR do parasita no sêmen (LOPES et al., 2009)

No entanto ocorre maior freqüência de ovinos sororeagente em animais adultos, aliados a altas titulações, sendo indicativo de infecção recente, sugerindo que a transmissão vertical não é a principal via de transmissão do agente, além dos adultos permanecerem por mais tempo em contato com as possíveis vias de transmissão do Toxoplasma gondii, resultando em maior chance de se infectarem (GARCIA et al., 1999; OGAWA et al., 2003; FIGLIUOLO et al., 2004; ROMANELLI et al., 2007). Pinheiro Junior et al. (2009) observaram que ovinos com 2 anos ou mais possuem quatro vezes mais chance de serem sororeagentes que animais com 2 meses ou menos de vida e ovinos com idade entre 12 e 24 meses 2,7 vezes mais em relação aos mesmos.

Quando é pesquisado se há suscetibilidade a infecção de acordo com o sexo, encontramos estudos que mostram que machos são mais susceptíveis (SILVA et al., 2003; UENO et al., 2009), outros que mostram que são as fêmeas (CLEMENTINO; SOUZA; ANDRADE NETO, 2007; PINHEIRO JUNIOR et al., 2009) ou ainda autores que não observaram diferença significativa entre os sexos (OGAWA et al., 2003; ALBUQUERQUE et al., 2009; LOPES et al., 2010).

Trabalhos que analisaram o fator de risco da infecção toxoplásmica em rebanhos nacionais mostram que animais com mais de 36 meses apresentaram risco de 1,45 vezes maior de se infectarem em relação aos mais jovens (CARNEIRO, 2006), assim como ovinos pertencentes a criatórios menores de 30 ha (ALBUQUERQUE et al., 2009; PINHEIRO JUNIOR et al., 2009), ovinos criados em terrenos planos e alagados em relação aos criados em terrenos planos ou acidentados, pois proporciona ambiente para a manutenção dos oocistos na pastagem (ALBUQUERQUE et al., 2009).

Alimentação a pasto e rações a granel em relação ao fornecimento de feno $(\mathrm{OR}=2,83)$ se mostra menos eficiente, pois aumenta a possibilidade de ingestão de oocistos assim como o não fornecimento de sal mineral em relação ao fornecimento, supondo que com essa falta de suplementação, os animais apresentariam o sistema imune mais frágil (OR=2,23) (LOPES et al., 2010).

Criações extensivas em relação à semi-extensivas (OR=1,68) (LOPES et al., 2010), criações semi-extensivas $(O R=3,17)$ e fonte de água corrente não tratada 
$(\mathrm{OR}=3.13)$ apresentaram mais riscos (PINHEIRO JUNIOR et al., 2009). Outros autores observaram também que em caso de animais criados em sistema de confinamento, ocorre maior risco de infecção devido exposição a fontes de infecção principalmente a oral quando há presença de felinos excretores (WALTNERTOEWS; MONDESIRE; MENZIES, 1991; MAINAR et al., 1996).

Romanelli et al. (2007) em seu estudo, relataram associação entre fonte de água e infecção, verificando que $35,08 \%$ dos ovinos sororeagentes eram provenientes de criatórios onde a água era oriunda de minas. No trabalho de Brandão et al. (2009), criatórios com fonte de água tratada possuíam maior risco da infecção $(O R=2,39)$ e as que fornecem água em bebedouros tipo balde apresentaram freqüência de $28,20 \%$ de sororeagentes $(O R=3,92)$, isso se deve possivelmente ao fato dos felinos defecarem próximos a reservatórios de água, onde não existe proteção e quanto aos bebedouros, esse modelo provavelmente facilita a contaminação da água por oocistos, por não possuírem proteção, diferente de bebedouros automáticos que possuem um sistema fechado.

A toxoplasmose é uma doença de cunho reprodutivo que gera grandes perdas econômicas em rebanhos de ovinos, onde a infecção é a principal causa de abortamentos, malformações fetais, nascimento de animais prematuros e mortes neonatais (MALIK; DEESEN; CRUZ, 1990; ESTEBAN-REDONDO; INNES, 1997).

Clinicamente em infecções naturais por Toxoplasma gondii as ovelhas geralmente não apresentam sintomas, com exceção de raros casos de retenção placentária (DUBEY; KIRKBRIDE, 1989). Sinais clínicos mais evidentes, principalmente em animais experimentalmente infectados são: pirexia, anorexia e aumento da freqüência respiratória (OWEN; CLARKSON; TREES, 1998; MORAES et al., 2010).

Ovelhas não gestantes, susceptíveis, geralmente não apresentam sintomas (VAUGHAN, 1996), ocorrendo à formação de cistos em tecidos nervosos e musculares (MARCA et al., 1996).

A toxoplasmose clínica ocorre quando as ovelhas se infectam pela primeira vez e a conseqüência da infecção difere de acordo com o estágio reprodutivo do ovino no momento da infecção. Se o parasita se instalar no início da gestação, podem ocorrer morte e absorção fetal, aparentando infertilidade. Ocorrendo no terço médio da gestação, o parasita se estabelece primeiramente na placenta e depois no 
feto. A capacidade do sistema imune do feto resistir à infecção irá depender da idade, pois a partir de 70 dias de gestação, é capaz de responder imunologicamente a infecção. No final do período gestacional, a infecção geralmente resulta no nascimento de cordeiros viáveis e saudáveis, infectados ou não (BUXTON et al., 1999).

Foi relatado cordeiro com escoliose e hidrocefalia devido toxoplasmose congênita (WOODS; ANDERSON, 1992).

A infecção de ovelhas com dois a quatro meses de gestação pode resultar em placentite severa, infecção fetal levando o feto à morte, mumificação e abortamento aos 40 dias após a exposição inicial. As ovelhas que abortam não apresentam sinais de doença sistêmica (VAUGHAN, 1996).

Ovelhas inseminadas com sêmen de machos contendo taquizoítos apresentaram absorção embrionária entre 18 e 21 dias após inseminação artificial (MORAES et al., 2010).

Existem lesões características observadas na placenta de ovinos acometidos por Toxoplasma gondii, sendo a principal delas à necrose de cotilédones, embora as áreas inter-cotiledonárias se apresentem normais, não resultando em placentite generalizada (DUBEY, 1990). Rhyan e Dubey (1984) observaram placentite necrosante, pneumonia, hepatite, nefrite intersticial e encefalite não supurativa focal em cordeiros que morreram aos dois dias de vida.

Esteban-Redondo et al. (1999), em inoculações experimentais conseguiram isolar cistos teciduais viáveis em amostras de coração, cérebro e musculatura esquelética de ovinos. A imunidade adquirida após a infecção persiste por toda a vida do animal (DUBEY; KIRBRIDE, 1989; ESTEBAN-REDONDO; INNES, 1997).

A pesquisa de Romanelli et al. (2007) mostrou relação entre fêmeas que apresentaram problemas reprodutivos no terço inicial da gestação e cordeiros com problemas neurológicos com sorologia positiva para Toxoplasma gondii. Associação importante também foi observada por Brandão et al. (2009) entre o parasita e casos de abortamento, relatando que em criatórios onde há histórico de abortamentos, o risco da presença do parasita é 2,89 maior que nos onde não há histórico.

Já Pinheiro Junior et al. (2009) não notaram associação significativa entre animais com histórico de distúrbios reprodutivos e a infecção por Toxoplasma gondii, embora tenha se observado taxas de prevalência mais elevadas em animais com 
essas características em relação aos que não apresentavam essas alterações, sendo elas $33,8 \%$ e $30,8 \%$ respectivamente. Não foi observado também significância entre animais que apresentaram quadro de abortamento, $31,7 \%$ (83/262), ou repetição de cio 52,6\% (10/18) com a presença da infecção.

Nos tecidos, histologicamente, são consideradas lesões característica de infecção toxoplásmica quando observa-se, infiltrados não supurativo multifocal com áreas de necrose circundadas por células inflamatórias, sendo o cérebro o órgão mais comumente afetado (PEREIRA-BUENO et al., 2004)

Em criatório do Rio Grande do Sul onde ocorreu surto de abortos no terço final de gestação em 58,3\% do rebanho, Motta et al. (2008), encontraram 3 de 9 amostras sororeagentes a Toxoplasma gondii em feto de um dos animais positivos, que apresentava sintomatologia respiratória com dispnéia e fraqueza. Foi observado à necropsia focos pálidos na superfície de corte do fígado, pulmões congestos $\mathrm{e}$ com aspecto marmorizado, coração com acentuada palidez e cérebro e cerebelo com severa congestão. Microscopicamente, havia no cérebro congestão severa, áreas de malácia com presença de cistos e taquizoítos dispersos onde havia microgliose e infiltração linfoplasmocitária moderada, além de microtrombose fibrinosa e meningite linfocitária difusa moderada, sugestivas de encefalite toxoplásmica. Nos cortes de pulmão, foram observadas extensas áreas de atelectasia, pneumonia intersticial linfocitária difusa moderada, exsudato fibrinoso intra-alveolar, além de micro abscessos focal. O fígado apresentava marcada congestão e focos de necrose centrolobular onde havia, em cortes corados com o PAS, estruturas compatíveis com taquizoítos. Foram observadas, também, miocardite linfocitária focal e nefrose tubular aguda associada à marcada congestão. A imunoistoquímica evidenciou marcação positiva para Toxoplasma gondii.

Como exposto em todas as enfermidades revisadas, a ovinocultura mesmo se tratando de um sistema de criação muito antigo em nosso país, ainda continua apresentando uma série de problemas, que dificultam a produção econômica desses animais e necessitam de urgentes soluções. Visando minorar estes prejuízos é de fundamental importância um estudo minucioso das enfermidades reprodutivas, objetivo desta tese. 


\section{MATERIAL E MÉTODOS}

\subsection{Amostragem}

Foram selecionados para o estudo ovinos machos e fêmeas que apresentaram histórico de problemas reprodutivos provenientes de criatórios do estado de São Paulo. As colheitas foram realizadas em 28 propriedades localizadas nos municípios de: Atibaia, Campinas, Cunha, Indaiatuba, Itapevi, Itatiba, Itu, Itupeva, Jundiaí, Morungaba, Pedra Bela, Piedade, Piracaia, Pirassununga, Santa Rita do Passa Quatro, Santo Anastácio, São Paulo, Sorocaba, Valinhos e Vargem.

Os animais utilizados no estudo apresentaram em seu histórico reprodutivo uma ou mais das alterações reprodutivas citadas a seguir:

Fêmeas: Abortamento, endometrite, malformação fetal, nascimento de cordeiro "fraco", natimortalidade, parto distócico, parto prematuro, presença de secreção uterina, prolapso uterino, repetição de cio, infertilidade e/ou retenção de placenta.

Machos: Infertilidade, degeneração, hiperplasia e hipoplasia testicular, orquite, epididimite e/ou falta de libido.

Foram colhidas 294 amostras, sendo de 257 fêmeas e 37 machos. Houve variação de amostras colhidas em cada propriedade de 1 a 40 animais.

\subsection{Colheita de dados}

Os dados foram obtidos no momento da colheita de material para diagnóstico das enfermidades do estudo e registrados em fichas específicas para o criatório e exame ginecológico e andrológico dos ovinos (Quadro 1, 2 e 3). 


\subsubsection{Criatórios ovinos}

Todas os 28 criatórios onde foram localizados e colhidos materiais para análise de animais com histórico de problemas reprodutivos, foram submetidas a questionário, quanto às características da criação. Os dados colhidos estão dispostos no quadro abaixo:

\begin{tabular}{|c|c|c|c|c|c|}
\hline \multirow{2}{*}{\multicolumn{3}{|c|}{$\begin{array}{l}\text { Criatório: } \\
\text { Endereço: }\end{array}$}} & \multicolumn{3}{|l|}{ Proprietário: } \\
\hline & & & \multicolumn{2}{|l|}{ Município: } & Telefone: \\
\hline \multicolumn{3}{|l|}{ Tamanho criatório: } & \multicolumn{2}{|l|}{ Clima da região: } & \\
\hline Presença de alagadiços? & ( & ( ) Não & \multicolumn{2}{|l|}{ Animais tem acesso? } & Não \\
\hline Presença de estábulo? & 1 & Não & \multicolumn{2}{|c|}{ Não } & \\
\hline Alimentação & & ) Pastagem ( ) Silo & \multicolumn{2}{|l|}{ ) Concentrado } & \\
\hline \multicolumn{6}{|l|}{ Raça: } \\
\hline Número total de animais & & Cordeiros & Matrizes & \multirow{2}{*}{\multicolumn{2}{|c|}{ 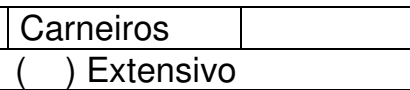 }} \\
\hline \multicolumn{2}{|l|}{ Sistema de criação } & ( ) Intensivo & ( ) Semi-intensivo ( ) Extensivo & & \\
\hline \multicolumn{2}{|c|}{ Há criação de outras espécies? } & () Sim ( ) Não & \multirow{2}{*}{\multicolumn{3}{|c|}{$\begin{array}{l}\text { Quais? } \\
\text { ( ) Aves ( ) Caninos ( ) Felinos ( ) Bovinos }\end{array}$}} \\
\hline \multicolumn{2}{|l|}{ Contato entre elas? } & $($ ) Sim ( & & & \\
\hline \multicolumn{2}{|l|}{ Presença de roedores? } & ( ) Sim & \multicolumn{3}{|c|}{ ( ) Aves ( ) Caninos ( ) Felinos ( ) Bovinos } \\
\hline \multirow{2}{*}{\multicolumn{2}{|c|}{$\begin{array}{l}\text { Tipo de monta } \\
\text { Fertilidade média rebanho/ano }\end{array}$}} & ( ) Natural & \multicolumn{2}{|c|}{ ) Inseminação artificial } & Mista \\
\hline & & & & & \\
\hline \multicolumn{5}{|c|}{ Índice anual de abortamentos } & \\
\hline \multicolumn{6}{|l|}{ Índice anual de natimortos } \\
\hline \multicolumn{2}{|l|}{ Vermifugação } & ( ) Sim ( ) Não & \multirow{2}{*}{\multicolumn{2}{|c|}{ Periodicidade: }} & \\
\hline \multicolumn{2}{|l|}{ Vacinação } & ( ) Sim ( ) Não & & & \\
\hline
\end{tabular}

Quadro 1 - Ficha de colheita de dados do criatório ovino - São Paulo - 2011

\subsubsection{Avaliação Clínica dos Animais}

Todos os animais com histórico de problemas reprodutivos onde foram colhidos materiais para diagnóstico foram examinados individualmente através do exame clínico geral e específico do aparelho genital de acordo com critérios recomendados por Rosenberger (1993) e suas observações foram registradas nos quadros clínicas a seguir. 


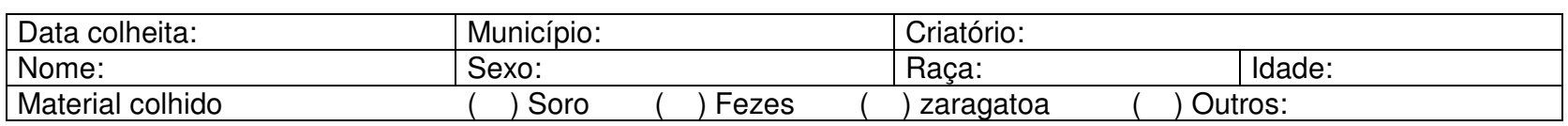

\section{Exame Clínico Vaginal}

\begin{tabular}{|l|l|l|}
\hline Tamanho & Secreção vaginal: $($ ) Sim $($ ) Não \\
\hline Simetria lábios & & \\
\hline Posição & & Cor: \\
\hline CicatrizlLesões & & Odor: \\
\hline Coloração & Consistência: \\
\hline Edema & OBS: \\
\hline Outros & & \\
\hline
\end{tabular}

\section{Exame Clínico Vulvar}

\begin{tabular}{|l|l|l|}
\hline \multicolumn{2}{|l|}{ Exame Clínico Vulvar } & Secreção: \\
\hline Traumas & & Cor: \\
\hline Vesículas & & Odor: \\
\hline Nódulos & & Quantidade (1 a 5): \\
\hline Petéquias & Aspecto: \\
\hline Cistos & OBS: \\
\hline Pústulas & \\
\hline FezeslUrina & \\
\hline
\end{tabular}

\section{Exame Clínico da Cerviz}

\section{Coloração:}

Anêmica - Pálida - Hiperêmica - Vermelho pálido \begin{tabular}{ll}
\hline ( ) Aberta ( ) Fechada \\
\hline Muco:
\end{tabular}

\section{Palpação Abdominal}

\begin{tabular}{|c|c|}
\hline Dor: $($ ) Sim $\quad(\quad)$ Não & $\begin{array}{ll}\text { Aumento de volume: } & (\mathrm{r}) \operatorname{Sim}(\mathrm{)}) \text { Não }\end{array}$ \\
\hline Consistência: & OBS: \\
\hline
\end{tabular}

\section{Histórico Reprodutivo}

\begin{tabular}{|c|c|c|c|c|c|c|}
\hline Data de Aquisição: & & & Parto prematuro: & & Sim & Não \\
\hline N de Partos: & & & \multicolumn{4}{|l|}{ Estado geral dos neonatos: } \\
\hline \multirow[t]{2}{*}{ Estado reprodutivo: } & \multirow{2}{*}{$\begin{array}{l}\text { ( ) Parto } \\
\text { ( ) Estro }\end{array}$} & \multirow{2}{*}{$\begin{array}{l}\text { () Anestro } \\
\text { ( ) Prenhes }\end{array}$} & Natimorto: & & Sim & Não \\
\hline & & & Nascimento cordeiros fracos & ( & Sim & Não \\
\hline Data último do parto & & & Malformações fetais: & ( & Sim & Não \\
\hline Aborto & ( ) Sim & ( ) Não & Morte neonatal: & 7 & Sim & Não \\
\hline Número: & & & Número: & & & \\
\hline Período gestação: & & & Idade: & & & \\
\hline Prolapso: & ( ) Sim & ( ) Não & Intervalo entre partos: & & & \\
\hline Parto distócico: & ( ) Sim & ( ) Não & Retenção de placenta: & ( & Sim & Não \\
\hline Repetição cio & $(1) \operatorname{Sim}$ & ( ) Não & Infertilidade: & $\overrightarrow{(}$ & Sim & Não \\
\hline
\end{tabular}

\section{Exame Clínico Geral}

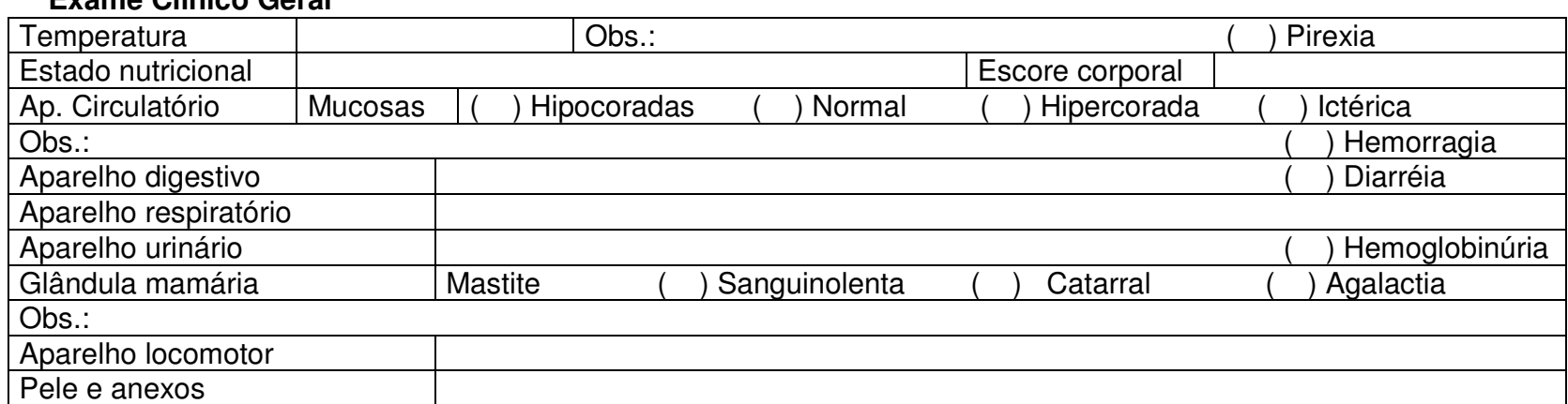

Quadro 2 - Ficha ginecológica de exame clínico do trato reprodutivo de fêmea ovina - São Paulo 2011 


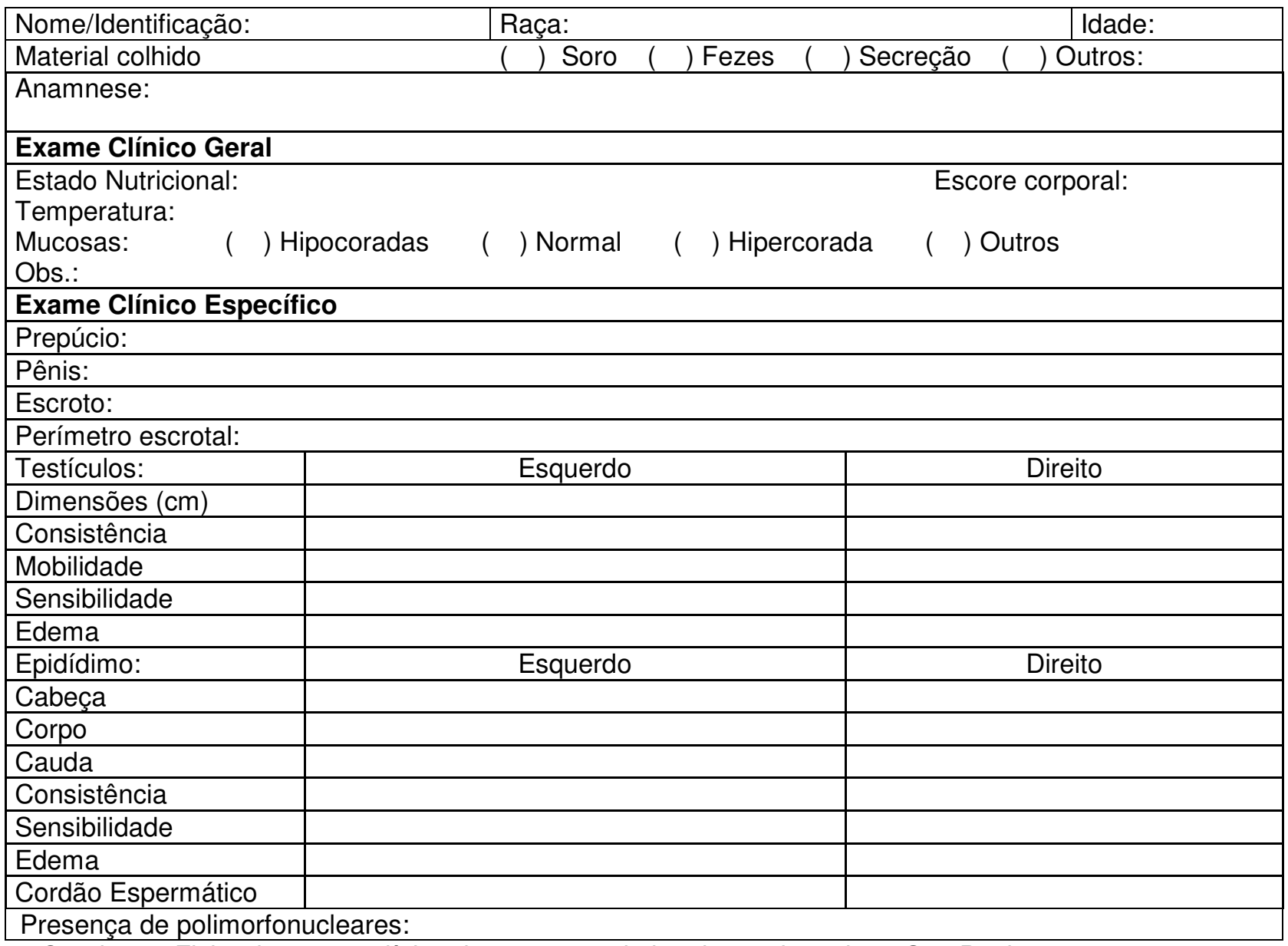

Quadro 3 - Ficha de exame clínico do trato reprodutivo de macho ovino - São Paulo - 2011

\subsection{Diagnóstico}

As 294 amostras, 257 fêmeas e 37 machos, de soro foram submetidas ao diagnóstico sorológico de Brucella ovis pelo teste de fixação do complemento, leptospirose por soroaglutinização microscópica, toxoplasmose e neosporose por imunufluorescência indireta.

Exames de isolamento bacteriano foram realizados em 274 amostras fecais, 255 fêmeas e 19 machos, para isolamento de Campylobacter spp. Outras amostras foram submetidas ao diagnóstico de isolamento a bactérias patogênicas sendo elas, Actinobacillus seminis, Brucella, Campylobacter spp., Histophilus somni e Leptospira. A quantidade e tipo de amostras analisadas foram; 16 fetos, 1 útero, 6 secundinas, 5 secreções uterinas, 5 zaragatoas vaginais, 17 amostras de sêmen, 3 
zaragatoas prepuciais, uma de urina e bile e de um macho sororeagente para Brucella ovis, epidídimos, pênis, próstata, bexiga, fígado, rins e baço.

A reação em cadeia da polimerase (PCR) foi realizada em 11 amostras fetais sendo 2 fetos para Brucella spp. e Leptospira spp., 4 para Toxoplasma gondii e Neospora caninum, 5 para Leptospira spp., Chlamydophila sp e Listeria monocytogenes. Uma amostra de secreção uterina para Histophilus somni e para Brucella spp uma amostra de fígado, baço, rins e urina.

\subsubsection{Colheita de amostras}

Foram colhidas amostras de soro, fezes, sêmen, zaragatoa prepucial, secreção uterina, zaragatoa vaginal, fetos, secundinas, cotilédones e órgãos: útero, testículos, epidídimos, pênis, próstata e rins dos ovinos utilizados no estudo.

\subsubsection{Soro}

A colheita de amostras de sangue para obtenção de soro foi efetuada por venopunção jugular com agulhas descartáveis em frascos de vidro estéreis, transparentes, sem anticoagulante, de forma asséptica e transportados sob refrigeração e armazenados em freezer, com acondicionamento em alíquotas, para posterior análise sorológica para Brucelose ovis, leptospirose, toxoplasmose e neosporose. 


\subsubsection{Fezes para isolamento de Campilobacter spp.}

As fezes foram colhidas por palpação retal com utilização de luva de procedimento e acondicionadas em frascos estéreis e transportadas sob refrigeração.

\subsubsection{Sêmen}

A colheita do sêmen foi inicialmente realizada com a utilização de vagina artificial. Em animais que não aceitaram esse método de colheita, o procedimento foi efetuado com o uso da técnica de eletroejaculação. As amostras de sêmen foram condicionadas em frascos de vidro estéreis e refrigeradas.

\subsubsection{Fetos Abortados}

Os fetos abortados foram devidamente conservados sob refrigeração, e enviados ao laboratório para isolamento de agentes patogênicos no período máximo de 24 horas.

\subsubsection{Secundínas e Secreções Uterinas}

As secundínas e as amostras de secreções uterinas foram colhidas em frascos de vidro ou plásticos estéreis, refrigeradas e enviadas ao laboratório para isolamento de agentes (Figura 1). 


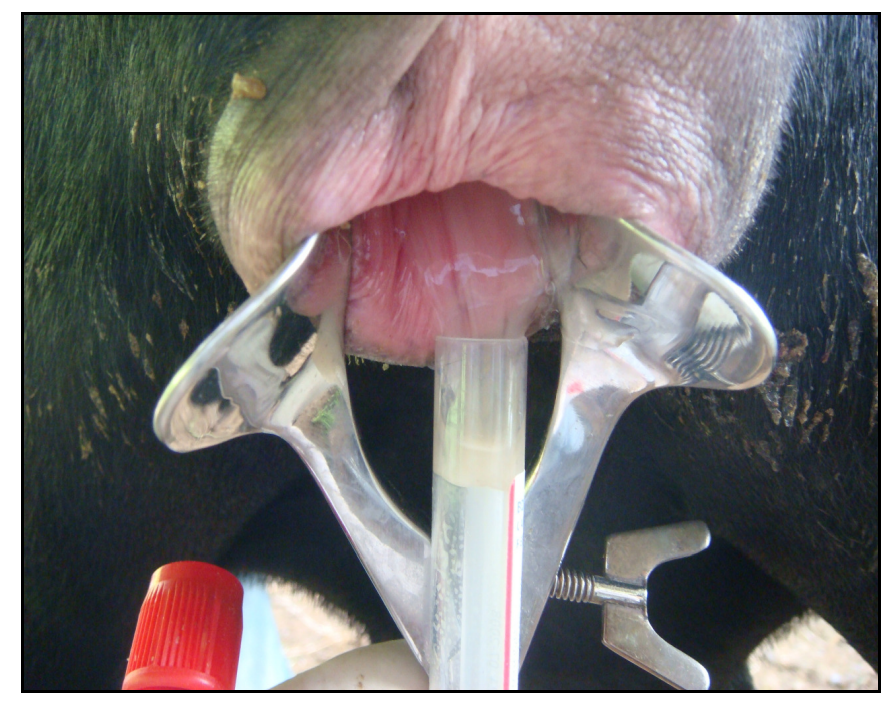

Figura 1 - Colheita de amostra de secreção vaginal mucosa com utilização de tubo estéril para realização de isolamento bacteriano - São Paulo - 2011

\subsubsection{6 Órgãos}

Os órgãos foram colhidos e após realização de exame macroscópico, foram conservados sob refrigeração e enviados ao laboratório para isolamento de agentes.

\subsection{Diagnósticos sorológicos}

O diagnóstico sorológico foi realizado para as seguintes enfermidades do que acomentem o trato reprodutivo de ovinos: brucelose, leptospirose, toxoplasmose e neosporose.

\subsubsection{Teste de fixação do complemento (RFC-0) para Brucella ovis}

Foi utilizada microtécnica descrita pela Internacional de Epizootias (OIE), executada em placas de poliestireno com fundo em "U", com incubação à temperatura de $37^{\circ} \mathrm{C}$ durante trinta minutos, em estufa bacteriológica, nas duas 
fases da reação. Para a realização da prova foi empregada uma quantidade de 25 $\mu \mathrm{L}$ de todos os componentes: soro teste, antígeno, complemento e sistema hemolítico.

\subsubsection{Antígeno para Brucella ovis}

O antígeno utilizado foi o Brucella ovis amostra REO 198 produzida pelo Instituto de Tecnologia do Paraná (TECPAR) na diluição de uso de 1:50. O antígeno foi padronizado por comparação com o soro padrão internacional de referência antiBrucella ovis adquirido no Central Veterinary Laboratory, laboratório de referência da OIE para brucelose.

\subsubsection{Diluição e inativação dos soros}

Inicialmente, os soros foram diluídos 1:5 em tampão Veronal (VB). Em seguida, foram deixados em banho Maria a $56^{\circ} \mathrm{C}$, durante 60 minutos, para inativar o complemento.

\subsubsection{Soroaglutinação microscópica para Leptospirose}

As amostras de soro foram processadas utilizando a reação de soroaglutinação microscópica, teste de referência recomendada pela Organização Mundial de Saúde com antígenos vivos e leitura em microscópio equipado com condensador de campo escuro (FAINE, 1982) utilizando bateria de antígenos pertencentes ao Laboratório de Zoonoses Bacterianas da Faculdade de Medicina Veterinária e Zootecnia da Universidade de São Paulo correspondentes as seguintes 27 leptospiras: Andamana sorovar andamana, Australis sorovar australis, Australis 
sorovar Bratislava, Autumnalis sorovar autumnalis, Ballum sorovar castellonis, Batavia sorovar bataviae, Canicola sorovar canicola, Celledoni sorovar whitcombi, Cynopteri sorovar cynopteri, Djasiman sorovar sentot, Grippotyphosa sorovar grippotyphosa, Hebdomadis sorovar hebdomadis, Icterohaemorrhagiae sorovar Copenhagen, Icterohaemorrhagiae sorovar icterohaemorrhagiae, Javanica sorovar javanica, Mini sorovar mini, Panama sorovar panamá, Pomona sorovar pomona, Pomona sorovar fronn, Pyrogenes sorovar pyrogenes, Seramanga sorovar patoc, Sejroe sorovar hardjo (hardjoprajitno), Sejroe sorovar hardjobovis, Serjoe sorovar wolffi, Shermani sorovar shermani e Tarassovi sorovar tarassovi. As leptospiras foram cultiváveis em meios especificamente desenvolvidos para seu metabolismo.

\subsection{Doenças Parasitárias}

As doenças parasitárias pesquisadas foram as causadas pelo Toxoplasma gondii e Neospora caninum. O diagnóstico sorológico foi realizado pela prova de Imunofluorescência indireta.

\subsubsection{Imunofluorescência indireta para Neospora caninum e Toxoplasma gondii}

Para a pesquisa de anticorpos anti-toxoplama e anti-neospora foi utilizada a técnica de imunofluorescência indireta (RIFI) segundo Camargo (1974) e Dubey et al. (1988), em lâminas para microscopia óptica sensibilizadas com taquizoítos de Neospora caninum e Toxoplasma gondii. O ponto de corte estabelecido para uma triagem das amostras foi de 1:50 para o Neospora caninum e 1:64 para o Toxoplasma gondii. Soros que determinem fluorescências na região apical dos taquizoítos de neospora/toxoplasma ou que determinem fluorescência parcial na superfície dos antígenos foram considerados negativos. Foram consideradas positivas apenas reações onde a presença de fluorescência foi total, ao redor da superfície dos taquizoítos, de acordo com os critérios adotados por Paré, Hietala e 
Thurmond (1995). A leitura das lâminas foi realizada em microscópio de fluorescência, com objetiva 40X.

\subsection{Diagnóstico microbiológico}

O diagnóstico microbiológico foi realizado para pesquisa de Campylobacter spp., Brucella spp., Leptospira spp., Actinobacillus seminis e Histophillus somni.

\subsubsection{Pesquisa de Campylobacter spp. em amostras de fezes.}

As amostras de fezes foram submetidas ao processamento bacteriológico, segundo técnica recomendada por Scarcelli et al. (1998):

Um grama de fezes foi pesada e preparada suspensão em $10 \mathrm{ml}$ de solução salina fisiológica estéril $(0,9 \%)$ e deixada decantar por cerca de 5 minutos. Em seguida $100 \mu \mathrm{L}$ (2 gotas) do sobrenadante foram semeados em meio de Brucella Ágar (DIFCO) acrescido de $5 \%$ de sangue desfibrinado de carneiro (meio ABS) e suplementado com mistura antibiótica composta por polimixina B (1.000 UI/L), cicloheximide (20 mg/l), novobiocina (5 mg/l) e bacitracina (15.000 UI/L).

Foram filtrados em membrana de poliestireno (MILLIPORE) com poro de 0,65 $\mu \mathrm{m}$ utilizando-se suporte plástico ("swinex" - MILLIPORE) e seringas estéreis e $2 \mathrm{ml}$ da suspensão e $100 \mu \mathrm{L}$ semeadas em meio ABS. As placas foram incubadas por 4872 horas a $37{ }^{\circ} \mathrm{C}$ em estufa de microaerofilia $\left(5 \% \mathrm{CO}_{2}\right)$. As colônias suspeitas foram identificadas segundo Bergey's Manual of Determinative Bacteriology (HOLT et al., 1994). 


\subsubsection{Pesquisa de Campylobacter spp., em amostras de fetos abortados, sêmen, secreção ou muco vaginal e prepucial}

As amostras de sêmen foram submetidas ao processamento bacteriológico, segundo critérios descritos por Genovez et al. (1999). Amostras de conteúdo gástrico e fragmentos de órgãos fetais (rim, fígado, pulmão e baço), secreção ou muco vaginal e prepucial foram submetidos ao processamento bacteriológico, segundo Scarcelli et al. (2004) e WHO (2004).

\subsubsection{Cultivo microbiológico de material clínico para Actinobacillus seminis}

As amostras de material clínico foram semeadas diretamente em meio de cultura composto por ágar Triptose (Difco) acrescido de $5 \%$ de soro fetal bovino e da mistura de antibióticos: polimixina B (Sigma) (1800 UI/L), ciclohexamida (Sigma) (30 mg/l) e bacitracina (Sigma) (7500 UI/L) (BROWN; RANGER; KELLEY, 1971).

Material clínico examinado: sêmen "in natura" (100 $\mu \mathrm{L})$; secreção ou muco vaginal e prepucial $(100 \mu \mathrm{L})$; macerado de "pool" de órgãos de feto ovino abortado (rim, fígado, pulmão e baço) em solução salina fisiológica estéril (100 $\mu \mathrm{L}$ ); conteúdo gástrico de feto ovino abortado (100 $\mu \mathrm{L}$ ), macerado de secundinas (placenta e anexos) em solução salina fisiológica estéril (100 $\mu \mathrm{L})$.

As placas foram incubadas sob microaerofilia, em estufa a $37^{\circ} \mathrm{C}$ durante 10 dias. Após o período de incubação, foi realizada a identificação das colônias suspeitas de acordo com Alton et al. (1976).

\subsubsection{Procedimento bacteriológico para isolamento e identificação de Brucella spp.}

Cem $\mu \mathrm{L}$ das amostras de sêmen "in natura" ou das secreções e mucos genitais foram semeadas em placas contendo meio de Brucella Ágar (DIFCO) 
acrescido com $5 \%$ de sangue desfibrinado de carneiro e incubadas por 72-120 horas a $37^{\circ} \mathrm{C}$, em estufa bacteriológica, sob microaerofilia $\left(5 \% \mathrm{CO}_{2}\right)$. Para isolamento de Brucella spp. as placas eram incubadas por pelo menos 10 dias. As colônias foram identificadas por meio da coloração de Gram e submetidas à série bioquímica correspondente ao agente suspeito, segundo Bergey's Manual of determinative bacteriology (HOLT et al., 1994).

\subsubsection{Diagnóstico microbiológico para Leptospira spp.}

Os materiais clínicos examinados (aborto e secundinas) foram cultivados em meio semi-sólido (Fletcher ou EMJH + Bacto ágar 0,2\%) (Difco) e meio líquido (EMJH) (Difco) com e sem mistura antibiótica (5-fluoruracil (300 mg/l) + ácido nalidíxico $(20 \mathrm{mg} / \mathrm{l})$ em estufa bacteriológica a $30^{\circ} \mathrm{C}$, sob aerobiose, por até 60 dias (MIRAGLIA et al., 2003).

\subsubsection{Procedimentos bacteriológicos para isolamento e identificação Histophlilus somni}

Cem $\mu \mathrm{L}$ das amostras de sêmen "in natura" ou das secreções e mucos genitais foram semeados em placas contendo meio de Ágar $\mathrm{BHI}$ com 0,5\% de Extrato de Levedura, 5\% de sangue desfibrinado de carneiro, 5\% de soro de fetal bovino, $3 \mu \mathrm{g} / \mathrm{ml}$ de lincomicina e $100 \mu \mathrm{g} / \mathrm{ml}$ de ciclohexamida e incubados por 48-72 horas, a $37^{\circ} \mathrm{C}$ em estufa bacteriológica, sob atmosfera de microaerofilia $\left(5 \% \mathrm{CO}_{2}\right)$. As colônias suspeitas foram identificadas conforme descrito acima (SCARCELLI et al., 2004). 


\subsection{Isolamentos parasitários}

O isolamento foi realizado para pesquisa dos parasitas Toxoplasma gondii e Neospora caninum.

\subsubsection{Preparo da amostra para isolamento de Neospora spp. e Toxoplasma gondii}

O sistema nervoso central (SNC) dos ovinos foi mantido refrigerado até 0 processamento das amostras, seguindo o protocolo preconizado por Dubey (1998). Fragmentos do SNC foram cortados em pequenos pedaços e macerados com cinco volumes de $\mathrm{NaCl}$ 0,15 M (salina). Ao material homogeneizado foi adicionado o mesmo volume de uma solução de pepsina ácida, pH 1,1-1,2 (pepsina, 2,6 g; $\mathrm{NaCl}$, $5,0 \mathrm{~g} ; \mathrm{HCl}, 7,0 \mathrm{ml}$; água destilada suficiente para $500 \mathrm{ml}$ de solução) recém preparada e aquecida em banho-maria a $37^{\circ} \mathrm{C}$. A mistura foi incubada em banhomaria sob agitação a $37^{\circ} \mathrm{C}$ por uma hora. Após incubação, a suspensão foi coada através de duas camadas de gaze e o coado transferido para cinco tubos cônicos de $50 \mathrm{ml}$ que foram centrifugados a $1200 \mathrm{~g}$ por 10 minutos. O sobrenadante foi desprezado e o sedimento de cada tubo neutralizado pela adição gradual de

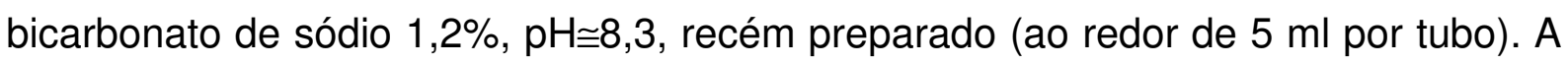
neutralização foi percebida visualmente pela mudança da cor do sedimento. Após homogeneização, o material foi transferido para um único tudo cônico, completandose o volume para $50 \mathrm{ml}$ com salina, e centrifugando a $1200 \mathrm{~g}$ por 10 minutos. Novamente, o sobrenadante foi dispensado e o sedimento ressuspendido com salina (v/v) contendo $2000 \mathrm{U}$ de penicilina e $200 \mu \mathrm{g}$ de estreptomicina por mililitro. Imediatamente as amostras preparadas como descrito foram inoculadas nos grupos de camundongos e em células VERO para identificação do Toxoplasma gondii e Neospora spp. 


\subsubsection{Isolamento do Neospora spp. e Toxoplasma gondii}

Foram utilizadas células da linhagem de rim de macaco verde africano (VERO), acrescidas de $10 \%$ de soro eqüino para o cultivo e manutenção dos taquizoítos de Neospora caninum. Foram inoculados $2 \mathrm{ml}$ de cada suspensão de cérebro em garrafas plásticas de $25 \mathrm{~cm}^{2}$ contendo monocamada pré-formada de células VERO e incubadas em estufa a $37^{\circ} \mathrm{C}$ por 2 horas. Após este período, os inóculos foram descartados e as monocamadas lavadas 3 vezes com PBS e adicionados $8 \mathrm{ml}$ de meio Eagle-MEM contendo $2 \%$ de soro eqüino e $1 \%$ de solução de antibióticos. As culturas foram observadas diariamente durante até 2 meses em microscópio óptico invertido, para verificar a presença de taquizoítos, que causam efeito citopático nas células.

No caso da toxoplasmose foram utilizados camundongos albinos Swiss, fêmeas, com idade ao redor de 1 mês (20-30 g). Cada grupo foi constituído de quatro camundongos, individualmente identificados e alojados na mesma caixa. Cada camundongo foi inoculado intraperitonealmente com $0,3 \mathrm{ml}$ da amostra digerida e observado diariamente. Os camundongos permaneceram em observação por até 6 semanas pós a inoculação. Após este período, dos animais que não apresentarem sinais clínicos de enfermidade, foram colhidos sangue e a eutanásia realizada em câmara de $\mathrm{CO}_{2}$. Os animais que venham a óbito são examinados para a pesquisa de Toxoplasma gondii nos tecidos

\subsection{Reação em cadeia da polimerase (PCR)}

A PCR foi realizado para detecção de Toxoplasma gondii e Neospora caninum. 


\subsubsection{Detecção de DNA de Toxoplasma gondii em órgãos dos camundongos}

Para detecção de DNA de Toxoplasma gondii em órgãos de camundongos de bioensaio, foi realizada a reação em cadeia pela polimerase. Uma alíquota de $0,2 \mathrm{~g}$ de cada órgão foi macerada com 0,8 ml de Tampão Eluição - TE $(1,2 \mathrm{~g}$ de Tris, $1 \mathrm{ml}$ de EDTA $0,5 \mathrm{M} \mathrm{pH} 8,1 \mathrm{~L}$ água milliQ, $\mathrm{pH} 7,4$ ) e mantida a $-20^{\circ} \mathrm{C}$.

\subsubsection{Extração do DNA de Toxoplasma gondii}

O DNA genômico foi extraído dos órgãos utilizando-se reagente comercial DNAzol (Invitrogen $\left.{ }^{\circledR}\right)$. Inicialmente a suspensão das amostras foi submetida à centrifugação 2.000 rotações por minuto (rpm) por cinco minutos, e $500 \mu \mathrm{L}$ do sobrenadante foram transferidos para novos tubos, identificados, centrifugados por 13.000 rpm durante 20 minutos, descartado o sobrenadante por inversão e ressuspenso o sedimento em $100 \mu \mathrm{L}$ de TE. Em seguida, foi adicionado $1 \mathrm{ml}$ de DNAzol (invitrogenR) e homegeneizado por inversão, centrifugado por $10.000 \mathrm{rpm}$ durante 10 minutos. Ao retirar o material da centrifuga desprezou-se o sobrenadante por inversão e foram adicionados $500 \mu \mathrm{L}$ de etanol puro, homogeneizada a amostra e centrifugada por $4.000 \mathrm{rpm}$ durante 2 minutos, desprezado o sobrenadante por inversão e adicionado $850 \mu \mathrm{L}$ de etanol $75 \%$, centrifugado por $4.000 \mathrm{rpm}$ durante 2 minutos. Novamente, desprezou-se o sobrenadante por inversão e foram acrescentados $850 \mu \mathrm{L}$ de etanol $75 \%$ e centrifugado.

O sobrenadante foi desprezado com o auxílio de pipeta, em seguida, ao sedimento foram adicionados $100 \mu \mathrm{L}$ de $\mathrm{NaOH}$ a $8 \mathrm{mM}$ e $40 \mathrm{~L}$ de solução HEPES $0,1 \mathrm{M}$. As amostras foram armazenadas a $-20^{\circ} \mathrm{C}$ até o momento de execução da PCR. 


\subsubsection{Ampliação do DNA de Toxoplasma gondii}

A amplificação do DNA de Toxoplasma gondii foi realizada utilizando-se o método descrito por Homan et al. (2000). Foram empregados os primers gênero específicos Tox4 e Tox5 (Tox 4: 5' CGC TGC AGG GAG GAA GAC GAA AGT TG 3' e Tox5: 5' CGC TGC AGA CAC AGT GCA TCT GGA TT 3') que amplificam fragmentos de 529 pb (HOMAN et al., 2000; GARCIA et al., 2006). A amplificação das amostras foi realizada com a utilização de $10 \mu \mathrm{L}$ de DNA extraído acrescido de $40 \mu \mathrm{L}$ da mistura de reagentes da PCR contendo 1,25 U taq DNA polimerase, $200 \mu \mathrm{M}$ de cada desoxinucleotídeo, tampão $(10 \mathrm{mM}$ Tris- $\mathrm{HCl}, \mathrm{pH}$ 8,0; $50 \mathrm{mM} \mathrm{KCl}$; $2 \mathrm{mM} \mathrm{MgCl} 2$ e $25 \mathrm{pmol}$ de cada primer. A amplificação foi realizada em termociclador iniciando com incubação a $94^{\circ} \mathrm{C}$ por 7 minutos, seguida de 35 ciclos a $94^{\circ} \mathrm{C}$ por 1 minuto (desnaturação), 55ํํ $\mathrm{C}$ por 1 minuto (anelamento), $72^{\circ} \mathrm{C}$ por 1 minuto (extensão) e 1 ciclo a $72^{\circ} \mathrm{C}$ por 10 minutos para a extensão final. As amplificações foram realizadas em termocicladora Peltier Thermal Cycler-100 (MJ Research). Como controle positivo para toxoplasmose foi utilizada a cepa cistogênica de Toxoplasma gondii e para controle negativo foi utilizada solução de diluição de amostras clínicas.

\subsubsection{Análise do produto amplificado}

Para a análise dos produtos amplificados foram realizadas por eletroforese em gel de agarose a 1,0\% com tampão TBE 0,5 X (0,045 M TRIS-Borato e $1 \mathrm{mM}$ de EDTA pH 8,0) e o gel corado com brometo de etídeo foi submetido à voltagem constante de 6-7 V/cm. 


\subsubsection{Ampliação do DNA de Neospora caninum e análise do produto amplificado}

A amplificação do DNA de Neospora caninum foi realizada utilizando-se o método descrito por Barratt et al. (2008)

3.6.6 Ampliação do DNA de Brucella spp, Leptospira spp., Chlamydophila sp e Listeria monocytogenes e análise do produto amplificado

A reação em cadeia da polimerase (PCR) para Brucella spp. e Leptospira spp., foi relizada segundo Richtzenhain et al. (2002) e a detecção de Chlamydophila sp e Listeria monocytogenes segundo Everett e Andersen (1999) e Aznar e Alacón (2003) respectivamente

3.7 Formas de análise dos resultados

Para descrever o perfil da amostra foram utilizadas técnicas de análise descritiva multidimensional para avaliar a proporção e quantidade de indivíduos em cada grupo das variáveis colhidas nas doenças. Na comparação entre os grupos, técnicas de análise de dados categorizados forneceram valores $\mathrm{p}$ para aceitar ou rejeitar a hipótese de teste. No caso, a hipótese testa a associação entre os grupos. Os testes dos grupos que apresentaram associações significantes $(p<0,1)$ foram avaliados sob a ótica da regressão logística, isto devido a este método estatístico expressar as medidas de riscos entre as variáveis do modelo (NETER, 1996; AGRESTI, 2002; BUSSAB; MORETTIN, 2004; PAULINO; SINGER, 2006).

No desenvolvimento das análises estatísticas foram utilizados os softwares R.2.7.1 (www.r-project.org), Minitab 14 e SPSS versão 15. 


\section{RESULTADOS}

A seguir serão expostos os resultados obtidos no estudo referentes a sete enfermidades do trato reprodutivo dos ovinos; brucelose, leptospirose, neosporose, toxoplasmose, campilobacteriose, Actinobacillus seminis e Histophilus somni.

4.1 Freqüência das características analisadas dos criatórios ovinos do estado de São Paulo

Estão dispostas nas tabelas abaixo a freqüência das informações obtidas nos criatórios ovinos no momento da colheita do material dos ovinos com histórico de problemas reprodutivos. Na tabela 1 , observa-se que a maioria dos criatórios onde foram colhidos materiais, era utilizado o sistema semi-intensivo de criação com animais a pasto durante o dia e estabulados no período da noite.

No entanto $15,3 \%$ das amostras colhidas foram oriundos de animais de criatórios onde não havia estabulação e os animais mantinham-se todo o tempo a pasto (Tabela 2).

Tabela 1 - Freqüência de ovinos submetidos à colheita de material que pertenciam a criatórios do estado de São Paulo com sistema de criação intensivo ou semiintensivo - São Paulo - 2011

\begin{tabular}{lc}
\hline Sistema de criação & Total de ovinos $(\%)$ \\
\hline Intensivo & $80(27,2 \%)$ \\
Semi-intensivo & $214(72,8 \%)$ \\
\hline
\end{tabular}

Tabela 2 - Freqüência de ovinos submetidos à colheita de material que pertenciam a criatórios do estado de São Paulo com ou sem estabulação - São Paulo - 2011

\begin{tabular}{|c|c|}
\hline Presença de estábulo & Total de ovinos (\%) \\
\hline Sim & $249(84,7 \%)$ \\
\hline Não & $43(15,3 \%)$ \\
\hline
\end{tabular}

Foi investigado o tipo de alimentação fornecida aos ovinos em relação a animais alimentados exclusivamente de pastagem, ou ainda os que recebiam no 
cocho concentrado e silagem. A maior freqüência foi de animais que se alimentavam de pasto e recebiam no cocho concentrado e silagem demonstrando assim certa tecnificação dos criatórios (Tabela 3).

Tabela 3 - Freqüência de ovinos submetidos à colheita de material e o tipo de alimentação fornecida nos criatórios do estado de São Paulo - São Paulo - 2011

\begin{tabular}{lc}
\hline Tipo de alimentação & Total de ovinos (\%) \\
\hline Pastagem & $51(17,3 \%)$ \\
Pastagem + concentrado & $90(30,6 \%)$ \\
Pastagem + concentrado + silagem & $106(36,1 \%)$ \\
Concentrado + silagem & $47(16 \%)$ \\
\hline
\end{tabular}

Foi observada a presença de outras espécies animais, que possuíam potencial para a transmissão das enfermidades estudadas, nos criatórios ovinos.

A presença de canídeos seguida de felídeos foram as mais freqüentes, elas podem transmitir respectivamente neosporose e toxoplasmose. Aves, um dos transmissores da campilobacteriose, esteve presente em criatórios de 141 ovinos do estudo e por último foi observado à criação consorciada de bovinos (Tabela 4).

Tabela 4 - Freqüência de ovinos submetidos à colheita de material pertencente a criatórios do estado de São Paulo onde havia a presença de espécies animais que podem agir como transmissores das enfermidades estudadas - São Paulo - 2011

\begin{tabular}{lc}
\hline Espécies animais & Total de ovinos em contato (\%) \\
\hline Aves & $141(48 \%)$ \\
Bovinos & $59(20 \%)$ \\
Caninos & $183(62 \%)$ \\
Felídeos & $192(65 \%)$ \\
\hline
\end{tabular}

A tecnificação dos criatórios pode ser estimada quanto ao tipo de fecundação realizada. A freqüência de animais pertencentes a criatórios onde apenas a monta natural era realizada foi ligeiramente menor aos dos animais que pertenciam a criatórios onde se aplicava inseminação artificial e/ou colheita e transferência de embriões, alem da monta natural (Tabela 5). 
Tabela 5 - Freqüência de ovinos submetidos à colheita de material pertencente a criatórios do estado de São Paulo onde se aplicava exclusivamente monta natural ou mista (monta natural e I.A. e/ou T.E) - São Paulo - 2011

Tipo de monta Total de ovinos (\%)

Mista
$162(55,1 \%)$

Natural $132(54,9 \%)$

4.2 Freqüências das características dos animais estudados, dados do exame ginecológico, andrológico e do histórico reprodutivo

Os 294 ovinos utilizados no estudo foram compostos por 6 raças e um grupo chamado de mestiços. A tabela 06 descreve a quantidade de animais pertencentes a cada grupo, sendo a raça Santa Inês responsável pela maior parte dos animais estudados $(53,4 \%)$.

\begin{tabular}{|c|c|c|c|}
\hline Raça & Fêmeas & Machos & Total (\%) \\
\hline Dorper & 13 & 16 & $29(9,9 \%)$ \\
\hline lle de France & 33 & - & $33(11,2 \%)$ \\
\hline Laucane & 2 & - & $2(0,7 \%)$ \\
\hline Mestiço & 20 & - & $20(6,8 \%)$ \\
\hline Santa Inês & 154 & 3 & $157(53,4 \%)$ \\
\hline Sulfok & 4 & 1 & $5(1,7 \%)$ \\
\hline Texel & 31 & 17 & $48(16,3 \%)$ \\
\hline Total & $257(87,4 \%)$ & $37(12,6 \%)$ & $294(100 \%)$ \\
\hline
\end{tabular}

A seguir serão listadas em tabelas as alterações clínicas observadas durante o exame clinico ginecológico e andrológico dos ovinos do estudo.

Quanto à vulva as alterações notadas no momento de sua inspeção externa estão expostas nas tabelas 7 e 8. 
Tabela 7 - Freqüência de alterações quanto ao tamanho da vulva em animais submetidos ao exame clínico ginecológico - São Paulo - 2011

\begin{tabular}{lccc}
\hline & Normal (\%) & Pequeno $(\%)$ & Grande $(\%)$ \\
\hline Tamanho & $248(96,5 \%)$ & $4(1,6 \%)$ & $5(1,9 \%)$ \\
\hline
\end{tabular}

No exame clínico, de uma fêmea da raça Texel com histórico de infertilidade, foi notado que o tamanho da vulva seria a causa da infertilidade, pois o orifício da mesma apresentava abertura insuficiente para a realização da cópula. As outras três fêmeas apresentavam vulva de tamanho menor que o habitual, no entanto aparentemente era possível a cópula (tabela 7).

Tabela 8 - Freqüência de alterações vulvares em animais submetidos ao exame clínico ginecológico - São Paulo - 2011

\begin{tabular}{lcc}
\hline & Sim $(\%)$ & Não $(\%)$ \\
\hline Simetria de lábios & $255(99,2 \%)$ & $2(0,8 \%)$ \\
Presença de cicatriz & $6(2,3 \%)$ & $251(97,7 \%)$ \\
Edema & $5(1,9 \%)$ & $252(98,1 \%)$ \\
\hline
\end{tabular}

Dos animais que apresentavam cicatriz na região vulvar, três foram conseqüência de distocia, dois devido à miíase e um à realização de sutura de Bühner para correção de prolapso vaginal. Assim como a assimetria de lábios, a presença de cicatriz na região externa da vulva não era grave a ponto de obstruir a cópula (tabela 8).

As tabelas a seguir descrevem alterações observadas na inspeção indireta da vagina com a utilização de espéculo e fonte luminosa (lanterna) durante exame ginecológico (Figura 2 e Tabelas 9 e 10).

Tabela 9 - Freqüência de alterações vaginais observadas durante a inspeção indireta - São Paulo - 2011

\begin{tabular}{lcc}
\hline & Presente (\%) & Ausente (\%) \\
\hline Cisto & $0(0,0 \%)$ & $257(100 \%)$ \\
Eritema & $1(0,4 \%)$ & $256(99,6 \%)$ \\
Mucosa hipercorada & $46(17,9 \%)$ & $211(82,1 \%)$ \\
Mucosa hipocorada & $13(5,1 \%)$ & $244(94,9 \%)$ \\
Nódulos & $15(5,8 \%)$ & $242(94,2 \%)$ \\
\hline
\end{tabular}




\begin{tabular}{lcc}
\hline Petéquias & $5(1,9 \%)$ & $252(98,1 \%)$ \\
Pústulas & $2(0,8 \%)$ & $255(99,2 \%)$ \\
Secreção & $66(25,7 \%)$ & $191(74,3 \%)$ \\
Telangectasia & $28(10,9 \%)$ & $229(89,1 \%)$ \\
Traumas & $5(5,8 \%)$ & $252(98,1 \%)$ \\
Vesículas & $1(0,4 \%)$ & $256(99,6 \%)$ \\
\hline
\end{tabular}

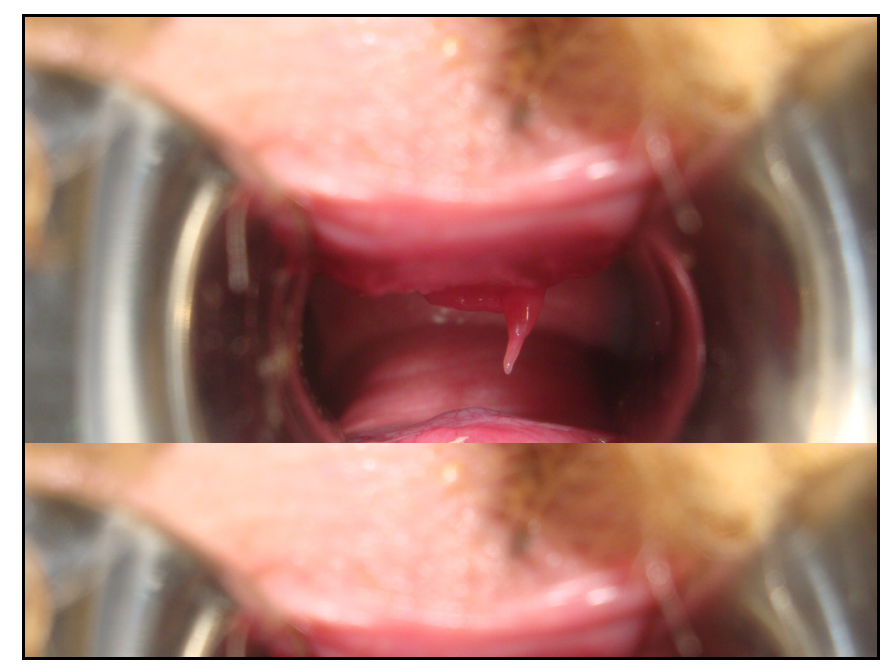

Figura 2 - Mucosa vaginal hiperêmica de ovino, observado no momento do exame ginecológico com a utilização de espéculo - São Paulo - 2011

No momento da inspeção vaginal com espéculo, em 66 (25,68\%) fêmeas foi observado presença de secreção vaginal, sendo que em 28 foram considerados secreções fisiológicas de estro, geralmente caracterizadas por secreção de consistência pastosa, coloração branca e inodora. Normalmente essa secreção estava aderida ao espéculo vaginal. Outras secreções observadas foram lóquios com coloração marrom, aspecto seromucoso e estrias de sangue e secreções de odor fétido de aspecto mucoso, seromucoso ou sanguinolento (Figuras 03 a 08 e Tabela 10).

Tabela 10 - Freqüência de secreções patológicas e fisiológicas observadas em 66 fêmeas que apresentaram secreção uterina no momento do exame ginecológico - São Paulo - 2011

\begin{tabular}{lcccc}
\hline Secreção & Patológica $(\%)$ & Estro (\%) & Lóquio (\%) & Total (\%) \\
\hline Total de ovinos & $38(57,6 \%)$ & $22(33,3 \%)$ & $6(9,1 \%)$ & $66(25,68 \%)$ \\
\hline
\end{tabular}



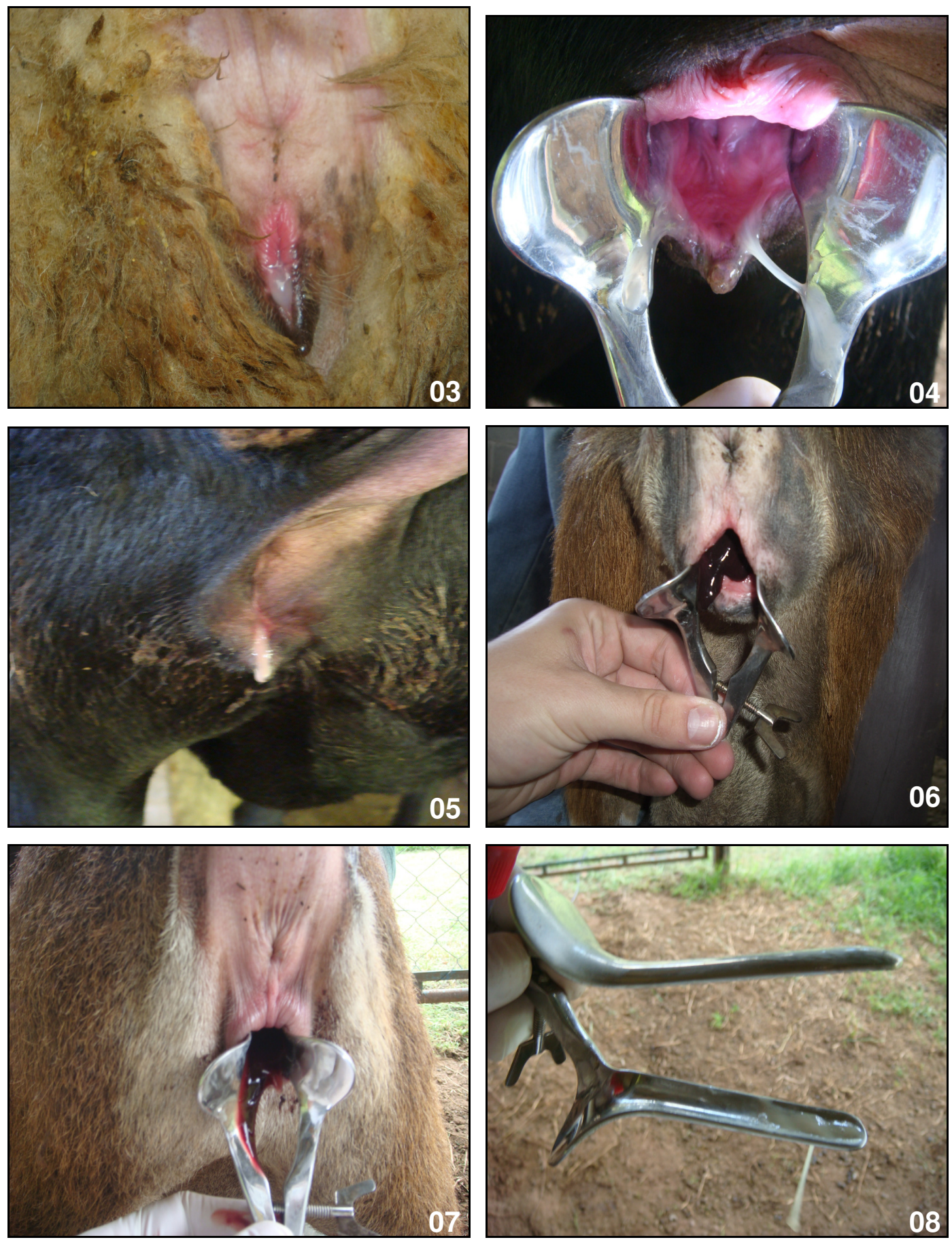

Figura 3 - Secreção uterina mucopurulenta de ovino da raça Texel - São Paulo - 2011

Figura 4 - Grande quantidade de secreção uterina mucopurulenta de ovino da raça Santa Inês - São Paulo - 2011

Figura 5 - Secreção uterina purulenta de ovino da raça Santa Inês - São Paulo - 2011

Figura 6 - Lóquio eliminado por ovino da raça Santa Inês, pós abortamento - São Paulo 2011

Figura 7 - Secreção uterina sanguinolenta de ovino da raça Santa Inês - São Paulo - 2011

Figura 8 - Secreção mucopurulenta aderida ao espéculo vaginal após exame ginecológico de ovino com histórico de abortamento - São Paulo - 2011 
A tabela 11 se refere a dados obtidos do histórico reprodutivo das fêmeas estudadas que foram colhidos através de registros dos animais no criatório ou de fatos observados no dia da colheita, sendo a presença de abortamento seguida de infertilidade/repetição de cio os mais incidentes e mais relatados pelos criadores. A categoria de nascimento de cordeiro "fraco" pode ou não estar relacionada com conseqüente morte neonatal por isso apresentam valores próximos de ocorrência.

Tabela 11 - Freqüência de alterações clínicas no histórico reprodutivo ou observadas no momento da colheita de material para diagnóstico de fêmeas ovinas submetidas ao exame ginecológico - São Paulo - 2011

\begin{tabular}{lc}
\hline Histórico reprodutivo & Total (\%) \\
\hline Abortamento & $136(52,9 \%)$ \\
Endometrite & $6(2,3 \%)$ \\
Malformação fetal & $3(1,2 \%)$ \\
Nascimento de cordeiro fraco & $30(11,7 \%)$ \\
Morte neonatal & $34(13,2 \%)$ \\
Natimorto & $7(2,7 \%)$ \\
Parto distócico & $6(2,3 \%)$ \\
Parto prematuro & $3(1,2 \%)$ \\
Prolapso uterino & $2(0,8 \%)$ \\
Repetição de cio/Infertilidade & $77(30 \%)$ \\
Retenção de placenta & $3(1,2 \%)$ \\
\hline
\end{tabular}

Quanto os abortamentos, em $59,56 \%$ dos casos ocorreram no momento da colheita ou o proprietário ou tratador relataram ter observado o fato e houve condições, por anotações de cobertura e/ou tamanho e aspecto do feto, de precisar o período de gestação no momento do abortamento (Figuras 09 a 14 e Tabela 12).

Tabela 12 - Freqüência do período de gestação que ocorreram abortamentos - São Paulo - 2011

\begin{tabular}{lccc}
\hline Período de gestação & Terço inicial $(\%)$ & Terço médio $(\%)$ & Terço final $(\%)$ \\
\hline Total de ovelhas & $11(13,6 \%)$ & $14(17,3 \%)$ & $56(69,1 \%)$ \\
\hline
\end{tabular}



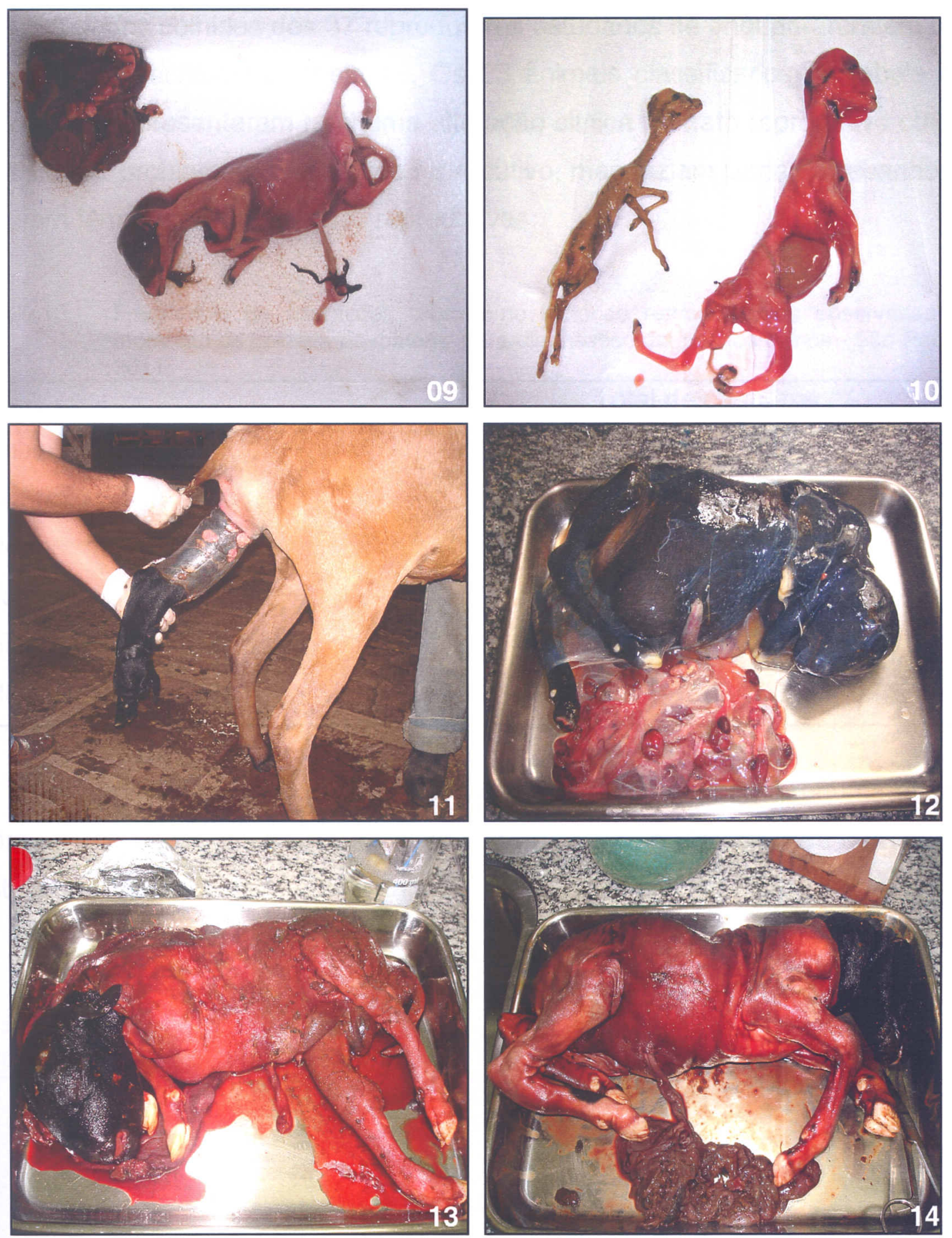

Figura 9 - Feto ovino da raça Santa Inês abortado no terço inicial de gestação - São Paulo -2011.

Figura 10 - Produtos de abortamento de gestação dupla de ovino da raça Santa Inês em terço inicial de gestação, sendo o menor feto de aspecto mumificado - São Paulo - 2011.

Figura 11 - Feto ovino da raça Santa Inês abortado em final de gestação - São Paulo - 2011.

Figura 12 - Feto ovino da raça Santa Inês abortado em terço final de gestação - São Paulo - 2011.

Figura 13 - Feto ovino da raça Dorper, proveniente de transferência de embriões, abortado em terço final de gestação - São Paulo - 2011

Figura 14 - Feto ovino da raça Dorper, proveniente de transferência de embriões, abortado em terço final de gestação - São Paulo - 2011 
Os dados colhidos dos 37 reprodutores estudados se enquadraram em um ou mais grupos descritos na tabela 13. Os 23 animais classificados na tabela como controle, não apresentaram nenhuma alteração clinica no trato reprodutivo ou relato de quaisquer problemas no histórico reprodutivo, mas faziam parte de rebanhos que possuíam fêmeas com alterações reprodutivas.

Tabela 13 - Freqüência de alterações clínicas no histórico reprodutivo ou observadas no momento da colheita de material para diagnóstico de machos ovinos - São Paulo 2011

\begin{tabular}{lc}
\hline & Total de carneiros (\%) \\
\hline Baixa fertilidade & $5(13,5 \%)$ \\
Controle & $23(62,3 \%)$ \\
Degeneração testicular & $2(5,4 \%)$ \\
Falta de libido & $4(10,8 \%)$ \\
Hiperplasia de epidídimo & $1(2,7 \%)$ \\
Hiperplasia testicular & $2(5,4 \%)$ \\
\hline
\end{tabular}

$\mathrm{Na}$ inspeção do trato genital masculino não foi observado nenhuma alteração de prepúcio e pênis, após exposto, enquanto no escroto observou-se dermatofitose e fístula na região caudal em dois animais.

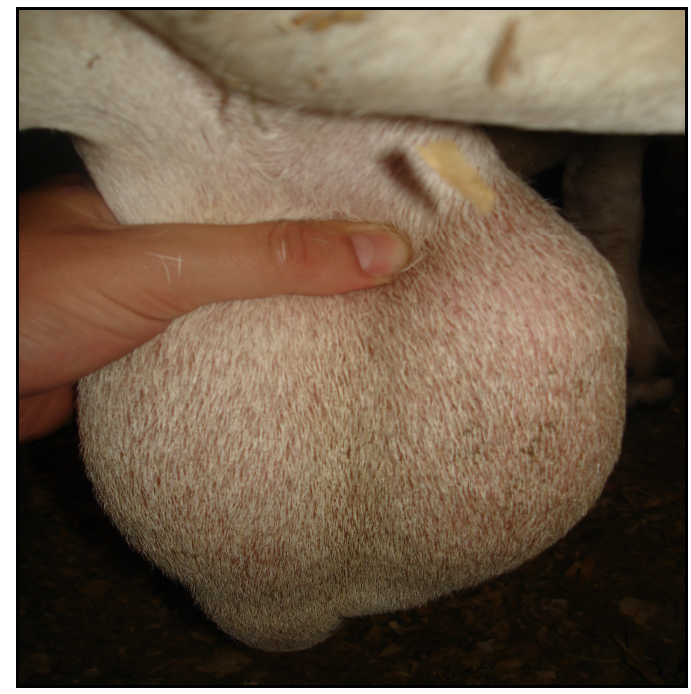

Figura 15 - Aumento de volume da região da cabeça do epidídimo direito - São Paulo - 2011

O perímetro escrotal nas diferentes raças de reprodutores variou de 23 a 43 $\mathrm{cm}$ com média de $31,8 \mathrm{~cm}$. 
A freqüência e característica das lesões observadas em testículos e epidídimos estão relatadas na tabela 14 .

\begin{tabular}{llc}
$\begin{array}{l}\text { Tabela } 14 \text { - Frequêencia de alterações clínicas em testículos e epidídimos de ovinos submetidos à } \\
\text { inspeção e palpaçao do trato reprodutivo - São Paulo - 2011 }\end{array}$ & \multicolumn{1}{c}{ Carneiros afetados (\%) } \\
\hline Órgãos & Lesões & $1(2,7 \%)$ \\
\hline Epidídimo esquerdo & $\begin{array}{l}\text { Nódulos palpáveis na } \\
\text { cauda }\end{array}$ & $2(5,4 \%)$ \\
Epidídimo direito & $\begin{array}{l}\text { Aumento de volume da } \\
\text { cabeça (Figura 15) }\end{array}$ & $1(2,7 \%)$ \\
& Nódulos na cabeça & $1(2,7 \%)$ \\
& Atrofia de cabeça & $1(2,7 \%)$ \\
& Aumento de volume do & \\
& corpo & $1(2,7 \%)$ \\
& Aumento de volume do & \\
& corpo & $2(5,4 \%)$ \\
& Nódulos palpáveis na & $1(2,7 \%)$ \\
Testículo esquerdo & cauda & $9(24,3 \%)$ \\
& Consistência firme & $2(5,4 \%)$ \\
Testículo direito & Consistência flácida & $7(18,9 \%)$ \\
& Consistência firme & $3(8,1 \%)$
\end{tabular}

Quadros clínicos característicos de epididimite ovina só foram observados em dois animais, sendo que um apresentou sorologia e isolamento negativos a Brucella ovis e outro fio realizado o isolamento de Actinobacillus seminis. 
4.3 Freqüências de ovinos sororeagentes a Brucella ovis em rebanhos do estado de São Paulo

Foram submetidos ao diagnóstico de Brucella ovis por imunidifusão em ágar gel 294 soros ovinos, sendo 257 fêmeas e 37 machos. Foi observado total de 5 animais sororeagentes, sendo 4 fêmeas e 1 macho (Tabela 15). O carneiro sororeagente a duas provas diagnósticas no intervalo de 6 meses, não apresentou alterações macroscópicas em seus testículos e epidídimos (Figuras 16 e 17).

Tabela 15 - Freqüência sorológica de Brucella ovis diagnosticada pela prova de fixação de complemento em 294 soros de ovinos com histórico de problemas reprodutivos - São Paulo - 2011.

\begin{tabular}{lccc}
\hline Sexo & Sororeagentes $(\%)$ & Não reagentes $(\%)$ & Total \\
\hline Fêmeas & $4(1,6 \%)$ & $253(98,4 \%)$ & 257 \\
Machos & $1(2,7 \%)$ & $36(97,3 \%)$ & 37 \\
Total & $5(1,7 \%)$ & $289(98,3 \%)$ & 294 \\
\hline
\end{tabular}

Quanto à titulação obtida nas fêmeas positivas foi observado em um animal a de 800 U.I. e em três animais 1.600 U.I., na amostra de macho positivo a titulação foi de 1.600 U.I. (Tabela 16).

Tabela 16 - Freqüência de titulação em unidades internacionais (U.I) de soros ovinos positivos para Brucella ovis pela prova de fixação de complemento - São Paulo - 2011

\begin{tabular}{lccc}
\hline & Fêmeas (\%) & Machos (\%) & Total (\%) \\
\hline Titilação 800 U.I. & $1(20 \%)$ & - & $1(20 \%)$ \\
Titilação 1.600 U.I. & $3(60 \%)$ & $1(20 \%)$ & $4(80 \%)$ \\
Total de animais & $4(80 \%)$ & $1(20 \%)$ & $5(100 \%)$ \\
\hline
\end{tabular}



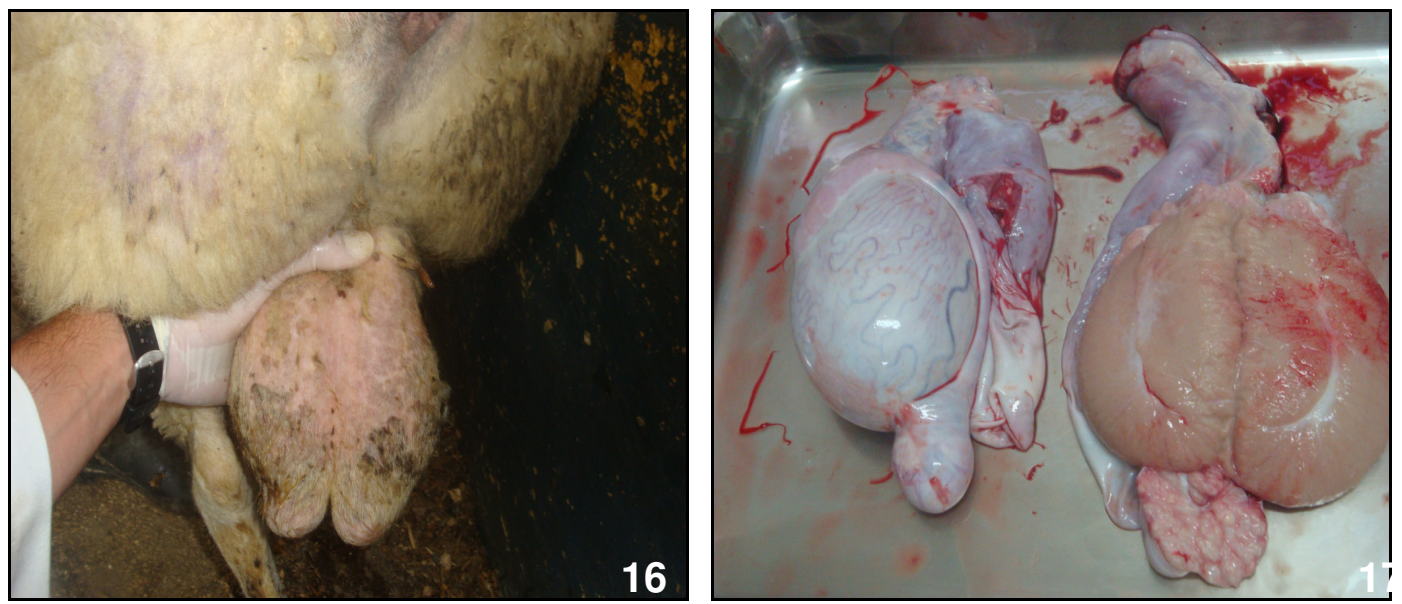

Figura 16 - Testículos de ovino da raça Texel positivo a Brucella ovis em duas prova sorológicas por fixação de complemento, sem presença de lesões testiculares palpáveis, São Paulo - 2001

Figura 17 - Testículos de ovino da raça Texel positivo a Brucella ovis em duas prova sorológicas por fixação de complemento, sem alterações macroscópica ao exame macroscópico post morten - São Paulo - 2011

4.4 Freqüências de ovinos sororeagentes a Leptospirose em rebanhos estado de São Paulo

Dos 294 soros submetidos à soroaglutinação microscópica para leptospirose foram observados 67 animais sororeagentes sendo 56 fêmeas e 11 machos (Tabela 17).

Tabela 17 - Freqüência de ovinos sororeagentes a Leptospirose pela prova de soroaglutinação microscópica em 294 soros de animais com histórico de problemas reprodutivos São Paulo - 2011

\begin{tabular}{lccc}
\hline Sexo & Sororeagentes (\%) & Não reagentes $(\%)$ & Total \\
\hline Fêmeas & $56(21,8 \%)$ & $201(78,2 \%)$ & 257 \\
Machos & $11(29,7 \%)$ & $26(70,3 \%)$ & 37 \\
Total & $67(22,8 \%)$ & $227(77,2 \%)$ & 294 \\
\hline
\end{tabular}

Ocorreram 87 reações de soroaglutinização com 15 sorovares diferentes. Os sorovares observados em ordem decrescente foram: Autumnalis sorovar autumnalis (33), Icterohaemorrhagiae sorovar icterohaemorrhagiae (11), Sejroe sorovar hardjo (hardjoprajitno) (9), Sejroe sorovar hardjobovis (7), Australis sorovar Bratislava, 
Ballum sorovar castellonis, Serjoe sorovar wolffi (4), Pomona sorovar pomona, Seramanga sorovar patoc (3), Grippotyphosa sorovar grippotyphosa, Panama sorovar panamá, Pyrogenes sorovar pyrogenes (2), Australis sorovar australis, Djasiman sorovar sentot e Icterohaemorrhagiae sorovar Copenhagen (1) (Tabela 18).

As titulações das amostras reagentes variaram entre 100 U.I. e 800 U.I., de modo que a titulação mais observada foi a de 100 U.I. em 38 animais. Em seguida vieram a de 200 U.I., 400 U.I. e 800 U.I. que ocorreram em 36, 9 e 3 animais respectivamente (Tabela 18).

Tabela 18 - Freqüência e distribuição de 87 reações de soroaglutinização com 15 sorovares diferentes na prova de soroaglutinação microscópica em 294 soros ovinos - São Paulo - 2011

\begin{tabular}{|c|c|c|c|c|c|c|c|c|c|c|c|}
\hline \multirow{2}{*}{$\begin{array}{l}\text { Titulação/Sexo } \\
\text { Leptospiras }\end{array}$} & \multicolumn{2}{|c|}{100 U.I. } & \multicolumn{2}{|c|}{200 U.I. } & \multicolumn{2}{|c|}{400 U.I. } & \multicolumn{2}{|c|}{800 U.I. } & \multicolumn{2}{|c|}{ Total } & \multirow{2}{*}{$\begin{array}{c}\text { Total } \\
\text { Ovinos }\end{array}$} \\
\hline & $\mathrm{F}$ & $\bar{M}$ & $\bar{F}$ & $\mathrm{M}$ & $\mathrm{F}$ & $M$ & $\mathrm{~F}$ & $M$ & $\mathrm{~F}$ & $\mathrm{M}$ & \\
\hline Australis sorovar australis & - & - & - & - & - & - & 1 & - & 1 & - & 1 \\
\hline Australis sorovar Bratislava & 3 & 1 & - & - & - & - & - & - & 3 & 1 & 4 \\
\hline Autumnalis sorovar autumnalis & 13 & 1 & 13 & 3 & 3 & - & - & - & 29 & 4 & 33 \\
\hline Ballum sorovar castellonis & 1 & 1 & 2 & - & - & - & - & - & 3 & 1 & 4 \\
\hline Djasiman sorovar sentot & 1 & - & - & - & - & - & - & - & 1 & - & 1 \\
\hline $\begin{array}{l}\text { Grippotyphosa sorovar } \\
\text { grippotyphosa }\end{array}$ & - & - & 1 & - & 1 & - & - & - & 2 & - & 2 \\
\hline $\begin{array}{l}\text { Icterohaemorrhagiae sorovar } \\
\text { Copenhagen }\end{array}$ & 1 & - & - & - & - & - & - & - & 1 & - & 1 \\
\hline $\begin{array}{l}\text { Icterohaemorrhagiae sorovar } \\
\text { icterohaemorrhagiae }\end{array}$ & 5 & 1 & 3 & 2 & - & - & - & - & 8 & 3 & 11 \\
\hline Panama sorovar panama & 1 & - & 1 & - & - & - & - & - & 2 & - & 2 \\
\hline Pomona sorovar pomona & 1 & - & 1 & - & 1 & - & - & - & 3 & - & 3 \\
\hline Pyrogenes sorovar pyrogenes & - & - & 1 & - & 1 & - & - & - & 2 & - & 2 \\
\hline Seramanga sorovar patoc & - & - & 1 & 1 & 1 & - & - & - & 2 & 1 & 3 \\
\hline $\begin{array}{l}\text { Sejroe sorovar hardjo } \\
\text { (hardjoprajitno) }\end{array}$ & 1 & 2 & 4 & - & 1 & - & 1 & - & 7 & 2 & 9 \\
\hline Sejroe sorovar hardjobovis & 5 & - & 1 & - & - & 1 & - & - & 6 & 1 & 7 \\
\hline Serjoe sorovar wolffi & 1 & - & 1 & 1 & - & - & 1 & - & 3 & 1 & 4 \\
\hline Total por sexo & 33 & 6 & 29 & 7 & 8 & 1 & 3 & - & $7 \xi$ & 14 & - \\
\hline Total de ovinos (F/M) & 3 & & 3 & & & & & & & 87 & \\
\hline
\end{tabular}


4.5 Freqüências de ovinos reagentes a Neospora caninum em rebanhos do estado de São Paulo

Foram processados 294 soros pela prova de imunofluorescência indireta, 257 fêmeas e 37 machos, dos quais 53 foram sororeagentes a diluição de 1:54, sendo 52 fêmeas e 1 macho (Tabela 19).

Tabela 19 - Freqüência de ovinos reagentes a Neospora caninum pela prova de imunofluorescência indireta com diluição de 1:50 em 294 soros de animais com histórico de problemas reprodutivos - São Paulo - 2011

\begin{tabular}{lccc}
\hline Sexo & Sororeagente $(\%)$ & Não reagente $(\%)$ & Total \\
\hline Fêmeas & $52(20,2 \%)$ & $205(79,8 \%)$ & 257 \\
Machos & $1(2,7 \%)$ & $36(97,3 \%)$ & 37 \\
Total & $53(18,0 \%)$ & $241(82,0 \%)$ & 294 \\
\hline
\end{tabular}

4.6 Freqüências de ovinos reagentes a Toxoplasma gondii em rebanhos do estado de São Paulo

Foi observado $29,9 \%$ de amostras sororeagentes a Toxoplasma gondii, sendo 79 fêmeas e 9 machos. A diluição utilizada na prova de imunofluorescência indireta foi de 1:64 (Tabela 20).

Tabela 20 - Freqüência de ovinos reagentes a Toxoplasma gondii pela prova de imunofluorescência indireta com diluição de 1:64 em 294 soros de animais com histórico de problemas reprodutivos - São Paulo - 2011

\begin{tabular}{lccc}
\hline Sexo & Sororeagente $(\%)$ & Não reagente $(\%)$ & Total \\
\hline Fêmeas & $79(30,7 \%)$ & $178(69,3 \%)$ & 257 \\
Machos & $9(24,3 \%)$ & $28(75,7 \%)$ & 37 \\
Total & $88(29,9 \%)$ & $206(70,1 \%)$ & 294 \\
\hline
\end{tabular}


4.7 Freqüências de isolamentos de Campylobacter spp. em amostras fecais ovinas em rebanhos estado de São Paulo

Das 274 amostras de fezes, 255 de fêmeas e 19 de machos foram observados o isolamento bacteriano em 9 (3,5\%) amostras de fêmeas e uma (5,3\%) de macho. Correspondente a $3,65 \%$ do total das amostras submetidas ao diagnóstico (Tabela 21).

Tabela 21 - Freqüência de isolados de Campylobacter spp. em 274 amostras fecais ovinas - São Paulo

\begin{tabular}{lccc}
\hline Sexo & Sororeagentes (\%) & Não reagentes (\%) & Total \\
\hline Fêmeas & $9(3,5 \%)$ & $246(96,5 \%)$ & 255 \\
Machos & $1(5,3 \%)$ & $18(94,7 \%)$ & 19 \\
Total & $10(3,65 \%)$ & $264(96,35 \%)$ & 274
\end{tabular}

No macho a espécie de campilobacter isolada foi o Campylobacter jejuni. Nas amostras de fêmeas, em uma não foi possível a identificação sendo assim denominado Campylobacter spp., enquanto 6 delas foram identificadas como Campylobacter jejuni e 2 como Campylobacter coli (Tabela 22).

Tabela 22 - Freqüência de espécies de Campylobacter nas 10 amostras fecais ovinas onde foi realizado isolamento - São Paulo - 2011

\begin{tabular}{lccc}
\hline & Fêmeas (\%) & Machos (\%) & Total (\%) \\
\hline Campylobacter spp. & $1(11,11 \%)$ & - & $1(10 \%)$ \\
Campylobacter coli & $2(22,22 \%)$ & - & $2(20 \%)$ \\
Campylobacter jejuni & $6(66,67 \%)$ & $1(100 \%)$ & $7(70 \%)$ \\
Total & $9(100 \%)$ & $1(100 \%)$ & $10(100 \%)$ \\
\hline
\end{tabular}




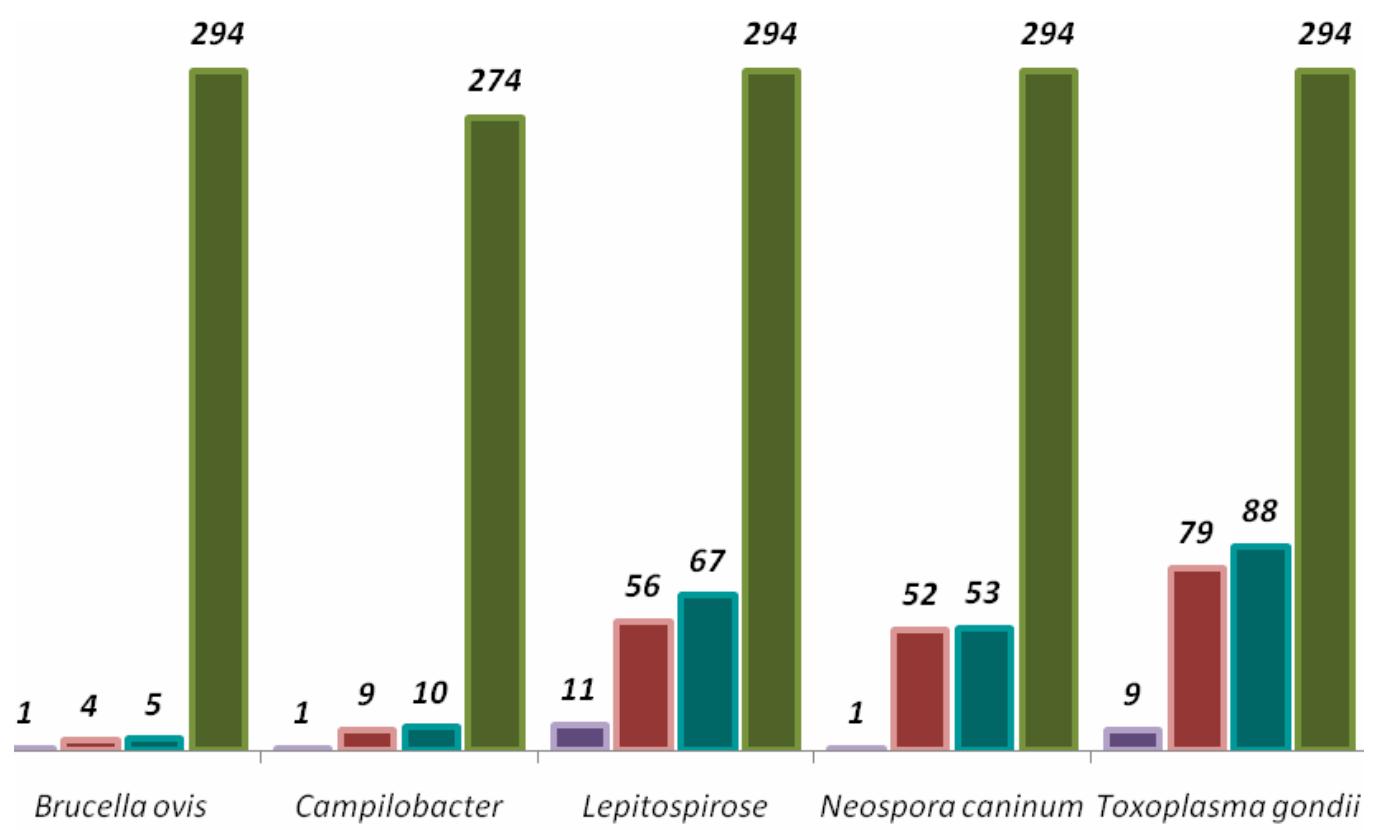

\begin{abstract}
Machos $\square$ Fêmeas $\quad$ Total de animais positivos $\quad$ Total Total de amostras colhidas
Gráfico 1 - Freqüência de ovinos sororeagentes a Brucella ovis, Leptospirose, Neosporose e Toxoplasmose e de isolamentos fecais de Campylobacter spp., divididos por sexo São Paulo - 2011
\end{abstract}

4.8 Freqüência de animais positivos a nenhuma, uma ou mais de uma das enfermidades estudadas

Do total de amostras analisadas, $110(37,4 \%)$ não foram sororeagentes a nenhuma das 5 enfermidades estudadas, Brucella ovis, leptospirose, neosporose, toxoplasmose e campilobacteriose. A quantidade de amostras que foram positivas apenas a uma das enfermidades foram; uma para Brucella ovis, 39 a leptospirose, 31 a neosporose, 51 a toxoplasmose e 5 a capilobacteriose (Tabela 23).

As 4 amostras de Brucella ovis restantes apresentaram sororeação positivas concomitantemente a leptospirose em um animal, toxoplasmose em 2 animais e no ultimo entre outras duas ao mesmo tempo sendo também leptospirose e 
toxoplasmose. Não ocorreu sororeação concomitantemente com Neospora caninum (Gráfico 2).

Quanto à leptospiras, além da Brucella ovis, foi observada interação com 4 amostras para Neospora caninum, 18 para Toxoplasma gondii e 3 para essas três enfermidades (Gráfico 3). Neosporose e toxoplasmose foram observadas ao mesmo tempo em 11 amostras (Gráficos 4 e 5).

Das 10 amostras onde ocorreram o isolamento do campilobacter, em 5 delas os animais não apresentaram sorologia positiva a nenhuma das quatro enfermidades estudadas. Dos 5 animais restantes, 2 deles foram positivos a Neospora caninum, 2 a Toxoplasma gondii e um único a mais de uma enfermidade sendo elas leptospirose e neosporose (Gráfico 6).

Tabela 23 - Distribuição das amostras de soro e fezes submetidas ao diagnóstico sorológico para Brucella ovis, Leptospirose, Toxoplasma gondii e Neospora caninum e bacteriológico para Campylobacter spp., demonstrando ocorrência de amostras sororeativas a uma ou mais das enfermidades estudadas ou ainda a nenhuma delas - São Paulo - 2011

\begin{tabular}{|c|c|c|c|c|c|}
\hline Brucella ovis & Leptospirose & $\begin{array}{c}\text { Toxoplasma } \\
\text { gondii }\end{array}$ & $\begin{array}{l}\text { Neospora } \\
\text { caninum }\end{array}$ & Campylobacter spp. & Total \\
\hline \multirow[t]{16}{*}{ Não reagente } & \multirow[t]{10}{*}{ Não reagente } & \multirow[t]{6}{*}{ Não reagente } & \multirow[t]{3}{*}{ Não reagente } & Não coletado & 11 \\
\hline & & & & Não reagente & 110 \\
\hline & & & & Reagente & 5 \\
\hline & & & \multirow[t]{3}{*}{ Reagente } & Não coletado & 1 \\
\hline & & & & Não reagente & 31 \\
\hline & & & & Reagente & 2 \\
\hline & & \multirow[t]{4}{*}{ Reagente } & \multirow[t]{3}{*}{ Não reagente } & Não coletado & 4 \\
\hline & & & & Não reagente & 47 \\
\hline & & & & Reagente & 2 \\
\hline & & & Reagente & Não reagente & 11 \\
\hline & \multirow[t]{6}{*}{ Reagente } & \multirow[t]{4}{*}{ Não reagente } & \multirow[t]{2}{*}{ Não reagente } & Não coletado & 3 \\
\hline & & & & Não reagente & 36 \\
\hline & & & \multirow[t]{2}{*}{ Reagente } & Não reagente & 4 \\
\hline & & & & Reagente & 1 \\
\hline & & \multirow[t]{2}{*}{ Reagente } & Não reagente & Não reagente & 18 \\
\hline & & & Reagente & Não reagente & 3 \\
\hline \multirow[t]{6}{*}{ Reagente } & \multirow[t]{3}{*}{ Não reagente } & Não reagente & Não reagente & Não reagente & 1 \\
\hline & & Reagente & Não reagente & Não coletado & 1 \\
\hline & & & & Não reagente & 1 \\
\hline & \multirow[t]{3}{*}{ Reagente } & Não reagente & Não reagente & Não reagente & 1 \\
\hline & & Reagente & Não reagente & Não reagente & 1 \\
\hline & & & & Total & 294 \\
\hline
\end{tabular}


Brucelloovis

- Brucella ovis e Lepitospirose

Brucella ovise Toxoplasmagondii

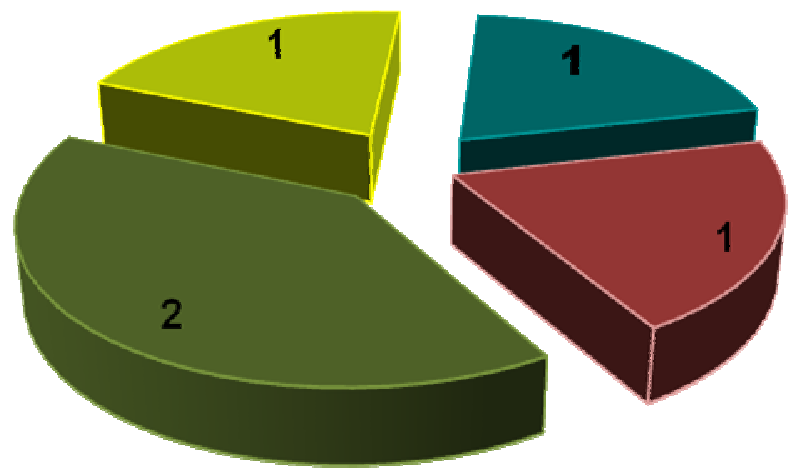

- Brucella ovis, Lepitospirose e Toxoplasmagondii

Gráfico 2 - Distribuição das 5 amostras de soros ovino reagentes a Brucella ovis pela prova de fixação de complemento em relação ao diagnóstico sorológico para Leptospirose, Toxoplasmose, Neosporose e isolamento bacteriano de Campylobacter spp. positivo concomitantemente São Paulo - 2011

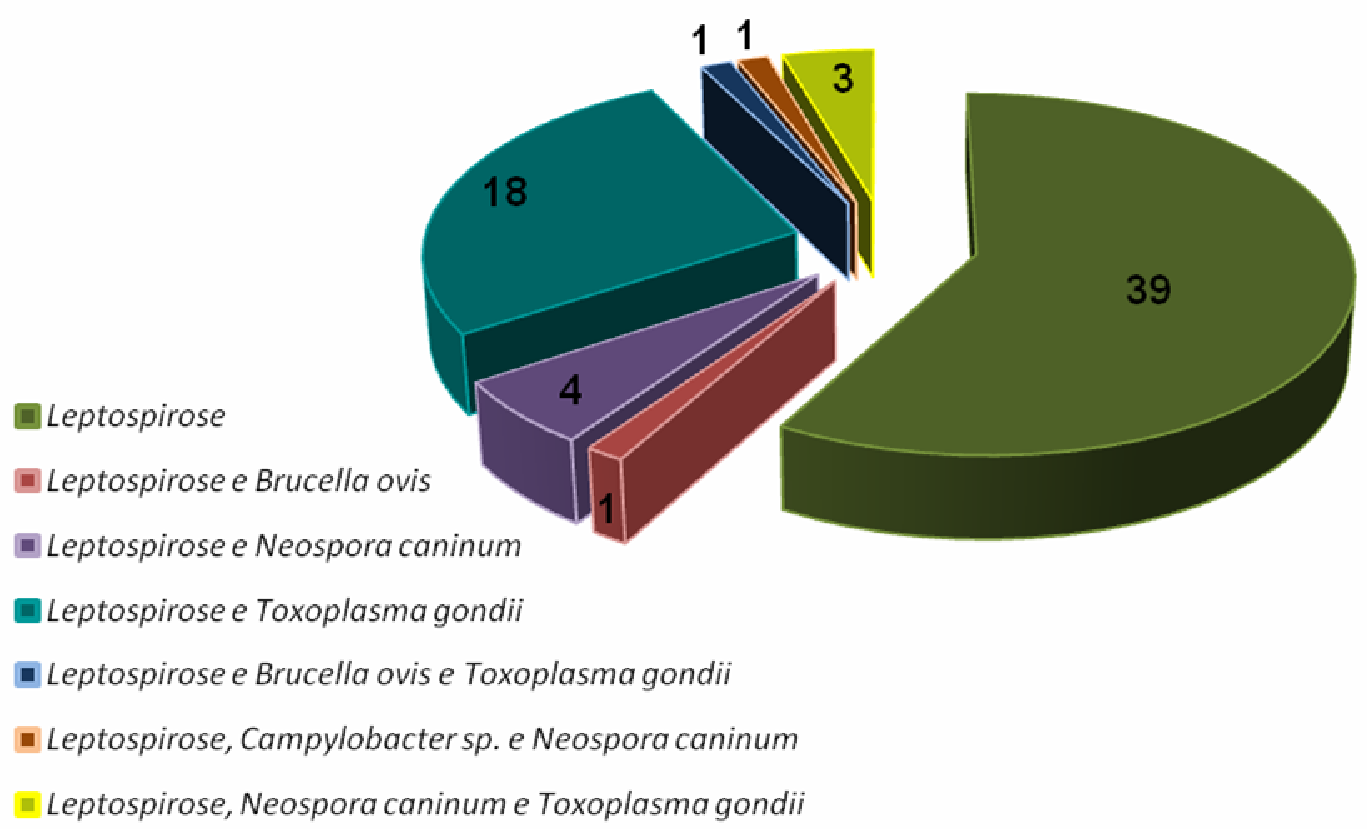

Gráfico 3 - Distribuição das 67 amostras de soros ovino reagentes a Leptospirose pela prova de soroaglutinação microscópica em relação à reação para Brucella ovis, Toxoplasma gondii e Neospora caninum e isolamento para Campylobacter spp. positivo concomitantemente - São Paulo - 2011 


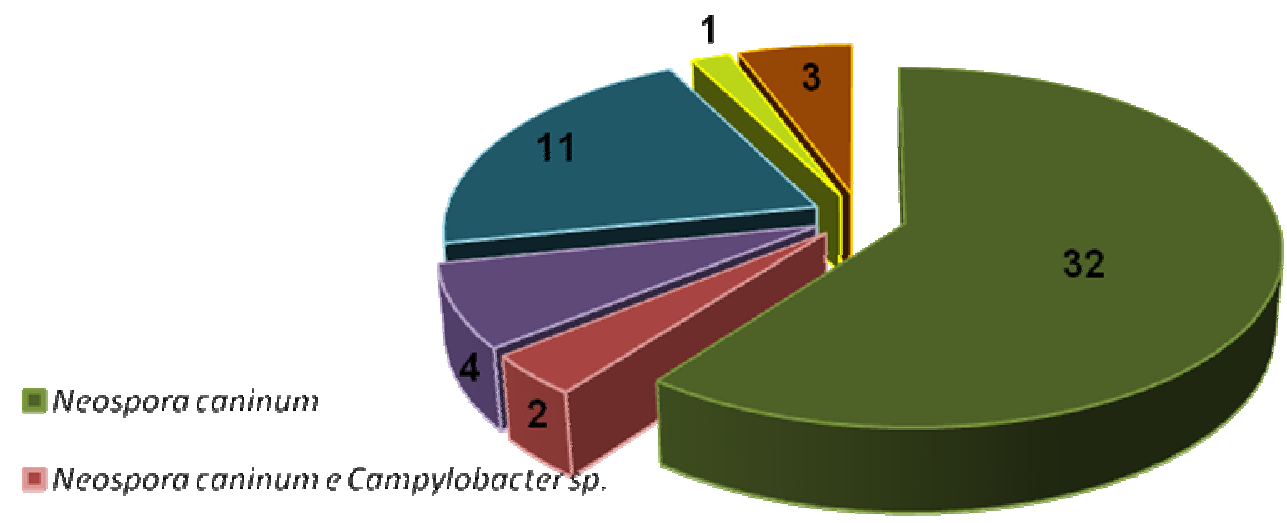

INeosporacaninum e Leptospirose

- Neospora caninum e Toxoplasma gondii

- Neospora caninum, Campylobactersp.e Leptospirose

Gráfico 4 - Distribuição de 53 amostras de soros ovino reagentes a Neospora caninum pela prova imunofluorecência indireta em relação à reação para Brucella ovis, Leptospirose e Toxoplasma gondii e isolamento para Campylobacter spp. positivo concomitantemente São Paulo - 2011

Toxoplasmagondii

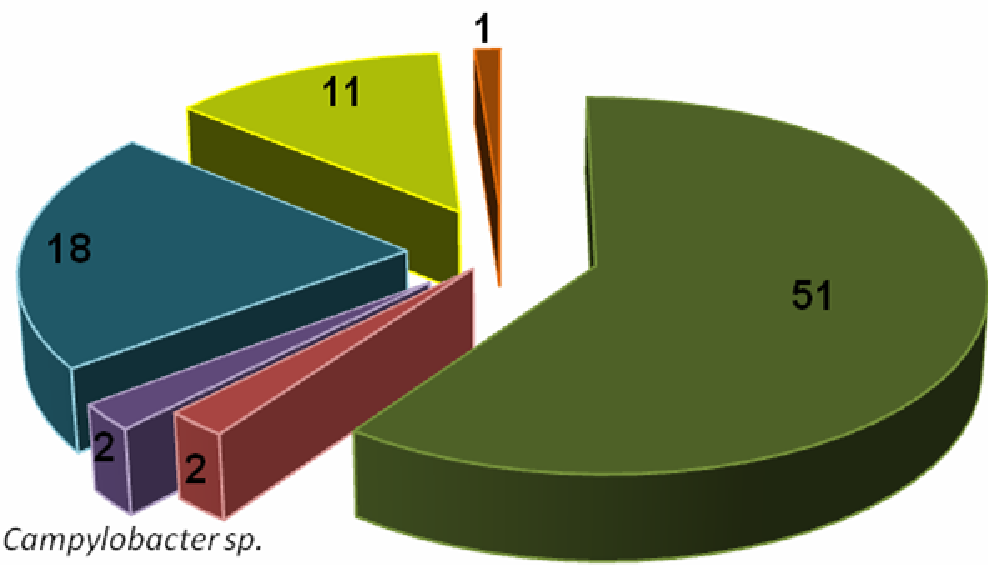

- Toxoplasma gondii e Campylobacter sp.

- Toxoplasma gondii e Brucella ovis

- Toxoplasmagondii e Leptospirose

- Toxoplasma gondii e Neospora caninum

- Toxoplasma gondii, Brucella ovis e Lepitospirose

Gráfico 5 - Distribuição das 88 amostras de soros ovino reagentes a Toxoplasma gondii pela prova imunofluorecência indireta em relação à reação para Brucella ovis, Leptospirose e Neospora caninum e isolamento para Campylobacter spp. positivo concomitantemente São Paulo - 2011 
- Campylonactersp.

- Campyloinactersp. e Neosporacaninum

- Campvlobactersp.c Toxoplasmagondii

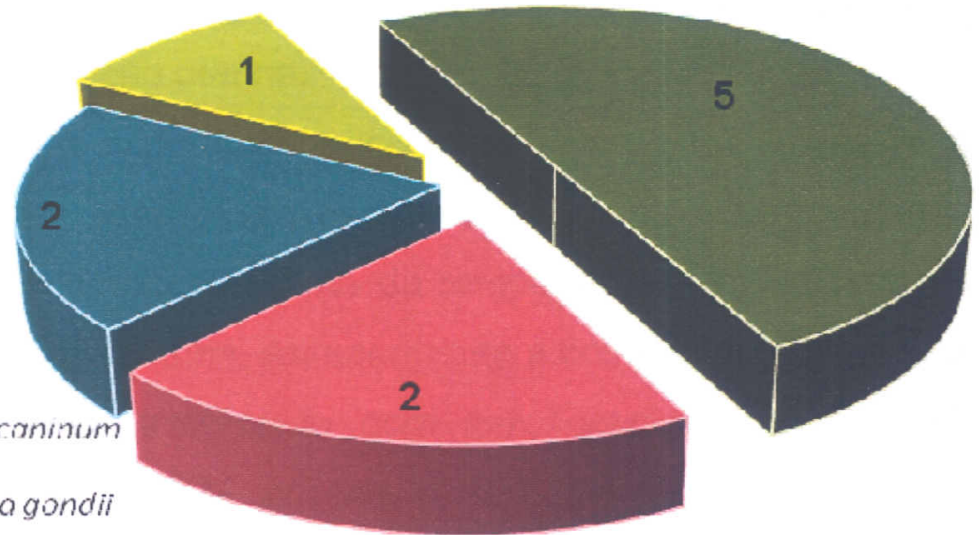

- Campylobactersp., Leptospirose e Ncosporaccinirum

Gráfico 6 - Distribuição das 10 amostras de fezes ovina onde foi realizado isolamento de Campylobacter spp. em relação sororeação a Brucella ovis, Leptospirose, Neospora caninum e Toxoplasma gondii concomitantemente - São Paulo - 2011

\subsection{Isolamentos de bactérias patogênicas}

Não ocorreu isolamento bacteriano de bactérias patogênicas pesquisadas, Actinobacillus seminis, Brucella sp., Campylobacter spp., Histophilus somni, Leptospira sp. nos 16 fetos abortados, 1 útero, 6 secundinas, 4 secreções uterinas, 5 zaragatoas vaginais, 17 amostras de sêmen, 3 zaragatoas prepuciais e em uma amostra de urina, bile, epidídimos direito e esquerdo, pênis, próstata, bexiga, fígado, rins e baço.

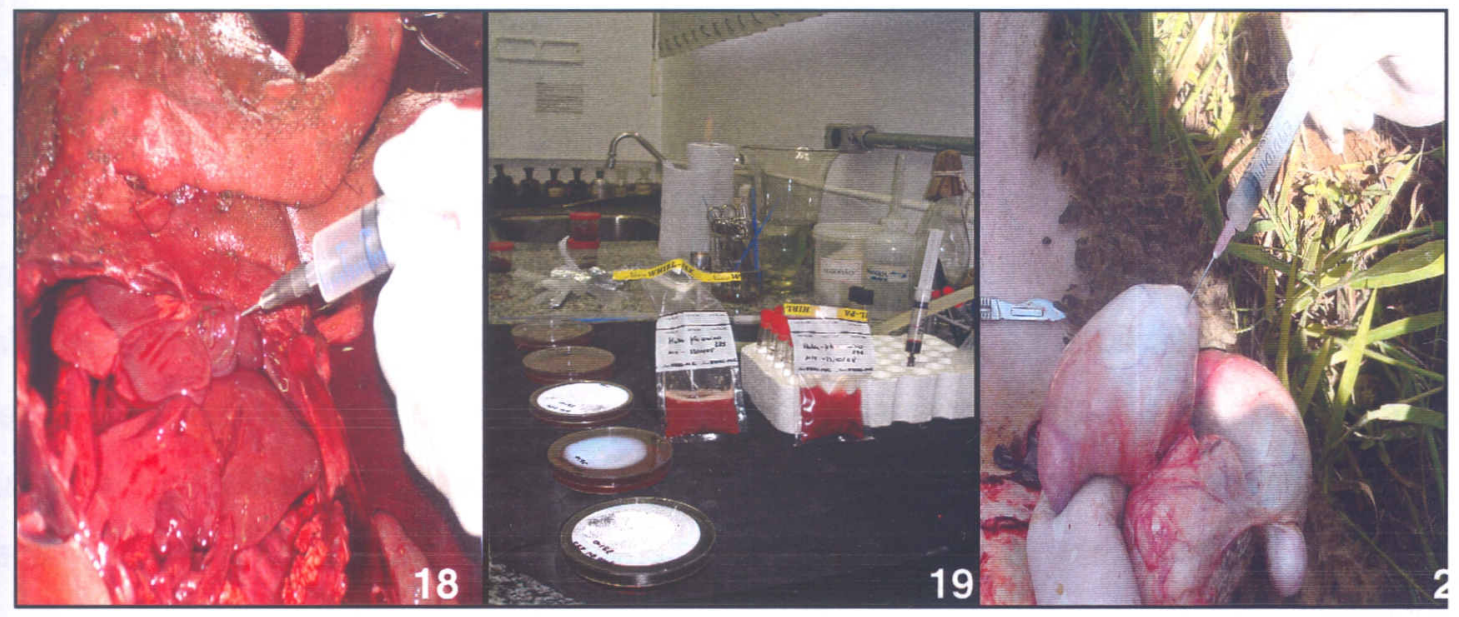

Figura 18 - Colheita de conteúdo gástrico de feto ovino abortado para realização de isolamento bacteriológico - São Paulo - 2011

Figura 19 - Pool de órgãos de feto ovino abortado para realização de isolamento bacteriológico - São Paulo - 2011

Figura 20 - Colheita post morten, através de punção epididimal, de sêmen ovino da raça Texel positivo sorologicamente a Brucella ovis, para realização de isolamento bacteriológico - São Paulo - 2011 
Os isolamentos de bactérias patogênicas ocorreram em duas amostras, sendo uma seminal e outra de secreção uterina.

$\mathrm{Na}$ amostra de sêmen foi isolado Actinobacillus seminis de macho da raça Dorper de 3 anos e 6 meses de idade com alto valor zootécnico apresentando aumento de volume do testículo direito, aumento da temperatura e diminuição da mobilidade testicular e quadro de hematúria. Anteriormente a colheita de sêmen, por vagina artificial, o animal recebeu tratamento com enrofloxacina 5\% (Baytrilß) Injetável 10\%), na dose de 2,5 mg/Kg/l.M. durante 5 dias, associado ao repouso sexual, onde se observou melhora do quadro. Após a cura clínica, o animal foi colocado em monta com 30 fêmeas durante 10 dias. Foi realizado exame ultrassonográfico após 40 dias e verificou-se taxa de gestação de 66,7\%. Durante a mesma estação de monta, foi realizado novamente o exame clínico do trato reprodutivo devido à informação do proprietário de que o animal apresentava-se apático, e notou-se que o testículo direito havia novamente aumentado de volume e que o animal recusava-se a montar as fêmeas. $O$ reprodutor foi retirado da estação de monta para repouso sexual e tratado com: dipirona sódica 500 mg (D 500®) 100 mg/dia/l.M. durante 3 dias, florfenicol $30 \mathrm{~g}$ (Nuflor®) 20 mg/kg/l.M. durante 7 dias e restrição de concentrado, sendo só alimentado com volumoso.

Trinta dias após o tratamento, foram realizados o exame andrológico e a colheita de sêmen, para realização de isolamento bacteriano. No momento do exame clínico, o animal apresentou: escore corporal de 3,5, mucosas hipocoradas e temperatura retal normal $\left(3^{\circ} \mathrm{C}\right)$.

$\mathrm{Na}$ avaliação dos órgãos genitais, observou-se: perímetro escrotal elevado (43 cm), testículo esquerdo com dimensões, consistência, mobilidade e sensibilidade normais, enquanto o testículo direito apresentou dimensões aumentadas, consistência firme, pouca mobilidade na bolsa, ausência de sensibilidade e presença de edema. Quanto ao epidídimo, o esquerdo se apresentou sem alterações, enquanto no direito, após a palpação, foi notado aumento de volume nas regiões de cabeça, corpo e cauda, ausência de sensibilidade e presença de edema.

A colheita de sêmen foi realizada pelo método da vagina artificial, utilizando uma fêmea em estro. O reprodutor em contato com a fêmea apresentou boa libido, fazendo vários saltos, no entanto sem ejacular. Após as tentativas de colheita, obteve-se uma amostra de 0,6 ml de ejaculado de aspecto aquoso e azospérmico. 
Foram colhidas também fezes para realização de exame bacteriológico para Campylobacter spp.

A amostra de sêmen foi encaminhada para a realização da cultura bacteriana em meio ágar triptose acrescido de $5 \%$ de soro fetal bovino (BROWN; RANGER; KELLEY, 1971). O resultado foi negativo para brucelose, Campylobacter spp., Histophilus somni, Mycoplasma spp. e Ureaplasma spp. e positivo para Actinobacillus seminis. Para descartar a possibilidade de o animal estar também infectado por Brucella ovis, foi colhida amostra de soro para realização do diagnóstico por fixação de complemento, sendo que o resultado também foi negativo.

Cinco meses após o início do quadro e do tratamento, avaliou-se o trato reprodutivo do animal, onde foi observada atrofia do testículo direito com consistência firme e sensível à palpação. Foi realizada nova colheita de sêmen para cultura (BROWN; RANGER; KELLEY, 1971) e antibiograma, confirmando o resultado obtido anteriormente de Actinobacillus seminis com resistência antibacteriana para: amicacina, cefoxitina, estreptomicina, sulfazotrim e cefalotina e sensível a: cloranfenicol, gentamicina, ciprofloxacim, eritromicina, norfloxacin, netilmicina, ampicilina, tetraciclina, carbenicilina e imipenem.

A amostra de secreção uterina foi colhida de fêmea da raça Texel que apresentava histórico de infertilidade, ocorrendo assim o isolamento em cultura pura de Histophilus somni. A queixa de infertilidade se deu, pois a fêmea não pariu após ter sido colocada para cobertura em estação de monta natural com reprodutores da mesma raça. No momento da colheita de soro e fezes foi realizado o exame ginecológico e com a passagem do espéculo foi possível observar secreção uterina de quantidade moderada, coloração esbranquiçado, aspecto mucoso e odor fétido, sendo indicativo de endometrite, uma vez que não foi observado abortamentos durante o período de gestação do lote que o animal pertencia. A mucosa vaginal apresentava-se normocorada, assim como a da cerviz que estava aberta. No exame clínico geral o animal não apresentava alterações. Nos exames sorológicos, o animal foi sororeagente a Toxoplasma gondii.

Foi realizado no macho soropositivo para Brucella ovis dois testes com intervalo de seis meses, a titulação de ambos foi de 800 U.I.. Alem da sorologia foi colhido amostra de sêmen para exame andrológico e bacteriológico sendo as duas 
amostras negativas com crescimento apenas de bactérias oportunistas; Escherichia coli, Staphylococcus spp e Proteus spp. Após o segundo resultado sorológico positivo o animal foi eutanasiado e realizado necropsia onde não foram observadas alterações macroscópicas no trato reprodutivo ou em qualquer sistema do ovino. Amostra seminal de punção epididimal foi colhida e não houve crescimento de nenhuma bactéria patogênica (Figura 20).

\subsection{Contaminações bacterianas}

Dentre as amostras submetidas ao exame de isolamento bacteriano, 16 fetos abortados, 1 útero, 6 secundinas, 4 secreções uterinas, 5 zaragatoas vaginais, 17 amostras de sêmen, 3 zaragatoas prepuciais e em uma amostra de urina, bile, epidídimo direito e esquerdo, pênis, próstata, bexiga, fígado, rins e baço, apenas duas amostras, sêmen e secreção uterina, ocorreram o isolamento de Actinobacillus seminis e Histophilus somni respectivamente, as demais não ocorreram isolamento ou foi observado o crescimento de bactérias caracterizando contaminação no momento da colheita. Dentre as mais prevalentes nos casos de contaminação foram observadas: Staphylcoccus spp (35), Escherichia coli (28), Bacillus spp (19) e Streptococcus spp (16). As amostras que mais apresentaram contaminação bacteriana secundária foram as de sêmen e secreção uterina (Tabela 24). 
Tabela 24 - Relação de bactérias isoladas em amostras de fetos, órgãos, sêmen, secreção uterina, secundinas, zaragatoa prepucial e vaginal fruto de contaminação bacteriana no momento da colheita - São Paulo - 2011

\begin{tabular}{|c|c|c|c|c|c|c|c|c|}
\hline & Fetos & Órgãos & Sêmen & $\begin{array}{c}\text { Secreção } \\
\text { uterina }\end{array}$ & Secundinas & $\begin{array}{c}\text { Zaragatoa } \\
\text { prepucial }\end{array}$ & $\begin{array}{c}\text { Zaragatoa } \\
\text { vaginal }\end{array}$ & Total \\
\hline Actinobacillus spp. & - & - & - & 1 & - & - & - & 1 \\
\hline Bacillus spp. & 4 & 5 & 8 & 1 & 1 & - & - & 19 \\
\hline Coliformes & - & - & - & - & - & - & 1 & 1 \\
\hline Enterobacter spp. & - & - & - & 2 & 2 & - & - & 4 \\
\hline Escherichia coli & 4 & 2 & 8 & 9 & 2 & 1 & 2 & 28 \\
\hline Nocardia spp. & - & - & - & 1 & - & - & - & 1 \\
\hline Proteus spp. & - & - & - & 2 & 1 & - & - & 3 \\
\hline Total & 15 & 14 & 32 & 23 & 10 & 5 & 7 & 112 \\
\hline
\end{tabular}




\subsection{Reação de Cadeia de Polimerase}

Foram submetidas à reação de cadeia de polimeras (PCR) 11 amostras fetais e não houve detecção de nenhum agente etiológico. Destas 11 amostras somente 2 foram realizadas o teste para Brucella sp e Leptospira sp, 4 para Toxoplasma gondii e Neospora caninum e 5 para Leptospira sp., Chlamydophila spp. e Listeria monocytogenes. Não foi possível a detecção de Brucella ovis na urina e órgãos, fígado, baço, rins, de carneiro que apresentou sorologia positiva a Brucella ovis pelo teste de fixação de complemento em duas amostras de soro colhidos com intervalo de 6 meses.

Foi detectado Histophilus spp. em amostra de secreção uterina de ovino da raça Texel que possuía histórico de infertilidade, confirmando assim o resultado obtido no isolamento bacteriano. Os oligonucleotídeos iniciadores empregados foram: HS-453F 5' GAA GGC GAT TAG TTT AAG AG -3' e HS-860R 5' TTC GGG CAC CAA GTR TTC A - 3'. Foi utilizada como controle positivo a cepa padrão ATCC 43625, a identificação do agente se deu pela revelação de um fragmento amplificado de 400 pb (ØYSTEIN; AHRENS; TEGTMEIER, 1998).

4.12 Freqüências das características analisadas dos criatórios ovinos do estado de São Paulo em relação a ovinos positivos as enfermidades estudadas

Em relação ao sistema de criação intensivo as enfermidades mais freqüentes foram leptospirose e toxoplasmose. Quando observamos o sistema semi-intensivo as freqüências decrescem em relação à toxoplasmose, neosporose, leptospirose, campilobacteriose e brucelose, sendo que se observarmos a neosporose a grande maioria dos animais positivos pertencem a rebanhos de sistema semi-intensivo com freqüência de 94,3\% (50/53) (Tabela 25). 
Tabela 25 - Freqüência de ovinos pertencentes a criatórios do estado de São Paulo positivos para as enfermidades estudadas em relação aos sistemas de criação intensivo ou semi-intensivo São Paulo - 2011

\begin{tabular}{lccccc}
\hline $\begin{array}{l}\text { Sistema de } \\
\text { criação }\end{array}$ & B.ovis & Leptospirose & Campylobacter spp & T. gondii & N. caninum \\
\hline Intensivo & $2 / 80$ & $22 / 80$ & $3 / 80$ & $20 / 80$ & $3 / 80$ \\
Semi-intensivo & $3 / 214$ & $45 / 214$ & $7 / 204$ & $68 / 214$ & $50 / 214$ \\
\hline
\end{tabular}

Todas as amostras positivas para brucelose e campilobacteriose foram oriundas de ovinos que pertenciam a propriedades com estabulação. No caso da leptospirose e toxoplasmose a grande maioria pertencem a esse tipo instalação, enquanto a neosporose apresentou a maior freqüência em criatórios sem estabulação (Tabela 26).

Tabela 26 - Freqüência de ovinos pertencentes a criatórios do estado de São Paulo positivos para as enfermidades estudadas em relação à presença ou não de estabulação - São Paulo - 2011

\begin{tabular}{lccccc}
\hline $\begin{array}{l}\text { Presença de } \\
\text { estábulo }\end{array}$ & B.ovis & Leptospirose & Campylobacter spp. & T. gondii & N. caninum \\
\hline Sim & & & & & \\
Não & $5 / 249$ & $58 / 249$ & $10 / 229$ & $79 / 249$ & $29 / 249$ \\
& $0 / 43$ & $9 / 43$ & $0 / 43$ & $8 / 43$ & $24 / 43$ \\
\hline
\end{tabular}

Ovinos alimentados somente a pasto apresentaram maior freqüência de sororeação ao Toxoplasma gondii, o mesmo ocorreu quando foi fornecido pastagem acrescida de concentrado e concentrado e silagem. No caso de fornecimento de apenas silagem e concentrado a maior freqüência foi dos animais sororeagentes a leptospirose (Tabela 27).

Tabela 27 - Freqüência de ovinos pertencentes a criatórios do estado de São Paulo positivos para as enfermidades estudadas em relação ao tipo de alimentação fornecida - São Paulo - 2011

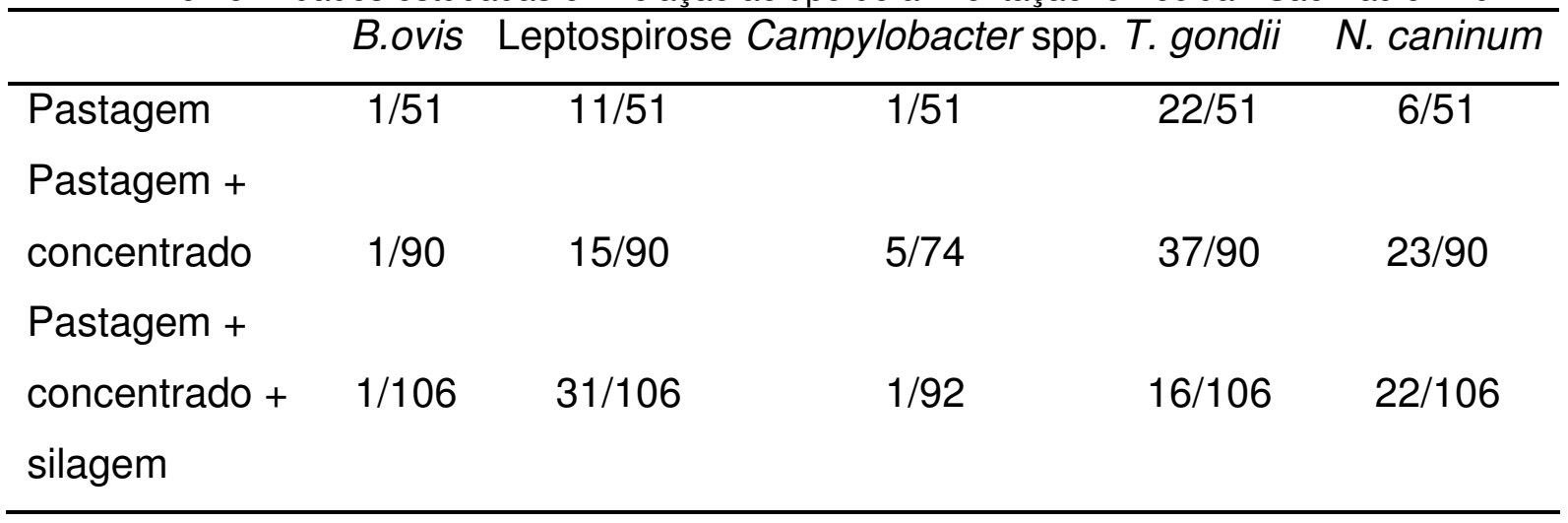




\begin{tabular}{llllll}
\hline $\begin{array}{l}\text { Concentrado }+ \\
\text { silagem }\end{array}$ & $2 / 47$ & $10 / 47$ & $3 / 47$ & $13 / 47$ & $2 / 47$ \\
\hline
\end{tabular}

Observando as espécies animais presentes nos criatórios e sua relação com a enfermidade que a mesmo pode ser transmissor, nota-se que $50 \%$ dos animais positivos para campilobacter pertenciam a criatórios que possuíam criação de aves. Quanto à presença de canídeos, que eliminam em suas fezes os oocistos de Neospora caninum, a freqüência de animais positivos ficou atrás da toxoplasmose e leptospirose nos criatórios que os possuíam. Nos criatórios onde haviam felinos a enfermidade mais observada foi a leptospirose com um animal a mais que a toxoplasmose, que pode ser transmitida pelas fezes contaminadas de felinos. A presença de bovinos nos criatórios esteve mais relacionada com animais sororeagentes à toxoplasmose e leptospirose (Tabela 28).

Tabela 28 - Freqüência de ovinos pertencentes a criatórios do estado de São Paulo positivos para as enfermidades estudadas em relação à presença de outras espécies animais no criatório São Paulo - 2011

\begin{tabular}{lccccc}
\hline & B.ovis & Leptospirose & Campylobacter spp. & T. gondii & N. caninum \\
\hline Aves & $2 / 141$ & $32 / 141$ & $5 / 125$ & $56 / 141$ & $22 / 141$ \\
Bovinos & $2 / 59$ & $15 / 59$ & $0 / 44$ & $19 / 59$ & $8 / 59$ \\
Caninos & $3 / 183$ & $43 / 183$ & $8 / 168$ & $58 / 183$ & $37 / 183$ \\
Felídeos & $3 / 192$ & $52 / 192$ & $8 / 177$ & $51 / 192$ & $32 / 192$ \\
\hline
\end{tabular}

Em criatórios com monta natural ocorreu maior incidência de toxoplasmose, enquanto em criatórios que realizavam além da monta natural, inseminação artificial e/ou transferência de embriões a maior freqüência de ovinos sororeagentes foi de leptospirose, seguido da neosporose (Tabela 29).

Tabela 29 - Freqüência de ovinos pertencentes a criatórios do estado de São Paulo positivos para as enfermidades estudadas em relação ao tipo de cobertura, natural ou mista (I.A. e/ou T.E) - São Paulo - 2011

\begin{tabular}{|c|c|c|c|c|c|}
\hline Tipo de monta & B.ovis & Leptospirose & Campylobacter spp & T. gondii & N. caninum \\
\hline Mista & $3 / 162$ & $42 / 162$ & $4 / 144$ & $36 / 162$ & $31 / 162$ \\
\hline Natural & $2 / 132$ & $25 / 132$ & $6 / 130$ & $52 / 132$ & $22 / 132$ \\
\hline
\end{tabular}


4.13 Freqüências de sinais clínicos observados e dados do histórico reprodutivo em relação a ovinos positivos as enfermidades estudadas

Analisando a freqüência dos sinais clínicos observados no momento do exame ginecológico é observado que a maior freqüência se deu na presença de mucosa hipercorada nos animais sororeagentes a leptospira e na presença de secreção vaginal nos sororeagentes a Toxoplasma gondii, que também apresentou números mais expressivos em alterações de mucosa vaginal como a hipercoloração e a telangectasia. No caso da Neospora caninum a maior freqüência foi nos casos de telangectasia da mucosa vaginal (Tabela 30 ).

\begin{tabular}{lccccc}
$\begin{array}{l}\text { Tabela } 30 \\
\text { - Relação entre animais sororeagentes para Brucella ovis, Leptospirose, Toxoplasma gondii e } \\
\text { Neospora caninum e com isolamento de Campylobacter spp. que apresentavam sinais } \\
\text { clínicos, em relação ao total de sinais clínicos observados } \\
\text { ginecológico de ovinos - São Paulo - 2011 }\end{array}$ & $\begin{array}{l}\text { nomento do exame } \\
\text { B.ovis }\end{array}$ & Leptospirose & Campylobacter spp. & T. gondii & N. caninum \\
\hline Cisto & $0 / 1$ & $0 / 1$ & $0 / 1$ & $0 / 1$ & $0 / 1$ \\
Mucosa hipercorada & $1 / 46$ & $11 / 46$ & $1 / 46$ & $11 / 46$ & $5 / 46$ \\
Mucosa hipocorada & $0 / 13$ & $5 / 13$ & $1 / 13$ & $4 / 13$ & $4 / 13$ \\
Nódulos & $1 / 15$ & $2 / 15$ & $6 / 15$ & $3 / 15$ & $0 / 15$ \\
Petéquias & $0 / 5$ & $1 / 5$ & $1 / 5$ & $3 / 5$ & $1 / 5$ \\
Pústulas & $0 / 2$ & $1 / 2$ & $0 / 2$ & $0 / 2$ & $0 / 2$ \\
Secreção & $0 / 38$ & $5 / 38$ & $2 / 38$ & $12 / 38$ & $1 / 38$ \\
Telangectasia & $0 / 28$ & $2 / 28$ & $0 / 28$ & $9 / 28$ & $7 / 28$ \\
Vesículas & $0 / 1$ & $0 / 1$ & $0 / 1$ & $1 / 1$ & $0 / 1$ \\
\hline
\end{tabular}

Entre os dados de histórico reprodutivo, o mais observado e consecutivamente que obteve maior número de animais positivos foi o abortamento que apresentou maior freqüência em animais sororeagentes a Toxoplasma gondii, seguido por leptospira, Neospora caninum, campilobacter e por último Brucella ovis. No caso da campilobacteriose o segundo item mais freqüente em animais onde foi realizado o isolamento fecal foi o quadro de nascimento de cordeiro "fraco" enquanto nas outras enfermidades foi o quadro de repetição de cio/infertilidade com Neospora 
caninum e Leptospirose com 21 animais positivos com esse quadro e Toxoplasma gondii e Brucella ovis com 16 e 1 consecutivamente (Tabela 31).

Tabela 31 - Relação entre animais sororeagentes para Brucella ovis, Leptospirose, Toxoplasma gondii e Neospora caninum e com isolamento de Campylobacter spp. que apresentavam histórico de problemas reprodutivos, em relação ao total de problemas no histórico reprodutivo de fêmeas ovinas - São Paulo - 2011

\begin{tabular}{lccccc}
\hline & B.ovis & Leptospirose & Campylobacter spp. & T. gondii & N. caninum \\
\hline Abortamento & $3 / 136$ & $23 / 136$ & $5 / 136$ & $48 / 136$ & $21 / 136$ \\
Endometrite & $0 / 6$ & $4 / 6$ & $1 / 6$ & $0 / 6$ & $0 / 6$ \\
Malformação fetal & $0 / 3$ & $0 / 3$ & $0 / 2$ & $1 / 3$ & $0 / 3$ \\
Morte neonatal & $0 / 34$ & $7 / 34$ & $3 / 33$ & $11 / 34$ & $9 / 34$ \\
Nascimento de & $0 / 30$ & $7 / 30$ & $4 / 29$ & $7 / 30$ & $7 / 30$ \\
cordeiro fraco & & & & & \\
Natimorto & $0 / 7$ & $3 / 7$ & $0 / 7$ & $2 / 7$ & $0 / 7$ \\
Parto distócico & $0 / 6$ & $2 / 6$ & $1 / 6$ & $2 / 6$ & $0 / 6$ \\
Parto prematuro & $0 / 3$ & $1 / 3$ & $0 / 3$ & $2 / 3$ & $0 / 3$ \\
Prolapso uterino & $0 / 2$ & $1 / 2$ & $0 / 2$ & $0 / 2$ & $0 / 2$ \\
Repetição de cio & $1 / 77$ & $21 / 77$ & $0 / 77$ & $16 / 77$ & $21 / 77$ \\
Retenção de placenta & $0 / 3$ & $0 / 3$ & $1 / 3$ & $0 / 3$ & $0 / 3$ \\
\hline
\end{tabular}

4.14 Significância ( $p$ ) e fator de risco entre os parâmetros analisados e as enfermidades estudadas

$\mathrm{Na}$ análise de significância em relação à raça dos ovinos do estudo, foi realizado o agrupamento dos animais pertencentes às raças, lle de France (33), Laucane (2), Sulfok (5) e Texel (48), formando o grupo denominado ovinos lanados (88). 


\subsubsection{Brucella ovis}

Ao realizar a análise de significância da Brucella ovis em relação ao sexo, raça, tipo de instalações, alimentação, sistema de criação, presença de outras espécies animais no criatório, tipo de monta, presença ou não de sinais clínicos no momento do exame ginecológico e presença ou não de distúrbios reprodutivos no histórico das fêmeas e machos ovinos, não foram observados valor de p significante em nenhum dos parâmetros analisados assim como mostra as tabelas 32, 33 e 34 . Isso se deve principalmente ao reduzido número de animais sororeagentes a Brucella ovis $(\mathrm{n}=5)$ dentre as amostras colhidas.

Tabela 32 - Análise de significância (valor de p) entre animais sororeagentes a Brucella ovis em relação ao sexo, raça, tipo de instalação, alimentação, sistema de criação, presença de outras espécies animais e tipo de monta - São Paulo - 2011

\begin{tabular}{|c|c|c|c|c|}
\hline Variável & Categoria & № de animais & Sororeagentes & Valor $p$ \\
\hline \multirow[t]{2}{*}{ Sexo } & Fêmea & 257 & $4(1,6 \%)$ & 0,62 \\
\hline & Macho & 37 & $1(2,7 \%)$ & Ref. \\
\hline \multirow[t]{4}{*}{ Raça } & Dorper & 29 & $0(0,0 \%)$ & - \\
\hline & Lanados & 88 & $2(2,3 \%)$ & 0,85 \\
\hline & Mestiços & 20 & $0(0,0 \%)$ & - \\
\hline & Santa Inês & 157 & $3(1,9 \%)$ & Ref. \\
\hline \multirow[t]{2}{*}{ Instalações } & Com estábulo & 249 & $5(2,0 \%)$ & - \\
\hline & Sem estábulo & 43 & $0(0,0 \%)$ & Ref. \\
\hline \multirow[t]{6}{*}{ Alimentação } & Pastagem & 51 & $1(2,0 \%)$ & Ref. \\
\hline & Pastagem + & & & \\
\hline & concentrado & 110 & $1(1,1 \%)$ & 0,69 \\
\hline & Pastagem + & & & \\
\hline & $\begin{array}{l}\text { concentrado + } \\
\text { silagem }\end{array}$ & 116 & $1(0,9 \%)$ & 0,60 \\
\hline & $\begin{array}{l}\text { Concentrado + } \\
\text { silagem }\end{array}$ & 47 & $2(4,3 \%)$ & 0,52 \\
\hline \multirow[t]{2}{*}{ Sist. de criação } & Intensivo & 80 & $2(2,5 \%)$ & 0,52 \\
\hline & Semi-intensivo & 214 & $3(1,4 \%)$ & Ref. \\
\hline
\end{tabular}




\begin{tabular}{|c|c|c|c|c|}
\hline \multicolumn{5}{|c|}{ Presença de outras espécies animais } \\
\hline & Bovinos & 59 & $2(3,4)$ & 0,28 \\
\hline & Caninos & 183 & $3(1,6 \%)$ & 0,92 \\
\hline & Felinos & 192 & $3(1,6 \%)$ & 0,80 \\
\hline & Aves & 141 & $2(1,4 \%)$ & 0,72 \\
\hline \multirow[t]{2}{*}{ Tipo de monta } & Natural & 132 & $2(1,5 \%)$ & 0,83 \\
\hline & Mista & 162 & $3(1,9 \%)$ & \\
\hline
\end{tabular}

Ref.: Parâmetro de referência na análise de significância

Valores de $p \leq 0,1$ são estatisticamente significantes

Tabela 33 - Análise de significância (valor de p) entre animais sororeagentes a Brucella ovis em relação à presença ou não de sinais clínicos no momento do exame ginecológico - São Paulo - 2011

\begin{tabular}{lcccc}
\hline Variáveis & Categoria & № de animais & Sororeagentes & Valor p \\
\hline Mucosa hipercorada & Sim & 46 & $1(2,2 \%)$ & 0,71 \\
& Não & 211 & $3(1,4 \%)$ & \\
Mucosa hipocorada & Sim & 13 & $0(0,0 \%)$ & - \\
& Não & 244 & $4(1,7 \%)$ & \\
Nódulos & Presente & 15 & $1(6,7 \%)$ & 0,14 \\
& Ausente & 242 & $3(1,2 \%)$ & \\
Petéquias & Presente & 5 & $0(0,0 \%)$ & - \\
\multirow{4}{*}{ Pústulas } & Ausente & 252 & $4(1,6 \%)$ & \\
& Presente & 2 & $0(0,0 \%)$ & - \\
Secreções & Ausente & 255 & $4(1,6 \%)$ & \\
\multirow{2}{*}{ Telangectasia } & Presente & 38 & $0(0,0 \%)$ & - \\
& Ausente & 219 & $4(1,8 \%)$ & \\
Vesículas & Presente & 28 & $0(0,0 \%)$ & - \\
& Ausente & 229 & $4(1,7 \%)$ & \\
& Presente & 1 & $0(0,0 \%)$ & - \\
& Ausente & 256 & $4(1,6 \%)$ &
\end{tabular}

Ref.: Parâmetro de referência na análise de significância

Valores de $p \leq 0,1$ são estatisticamente significantes 
Tabela 34 - Análise de significância (valor de p) entre animais sororeagentes a Brucella ovis em relação à presença ou não de distúrbios reprodutivos no histórico de fêmeas ovinas São Paulo - 2011

\begin{tabular}{|c|c|c|c|c|}
\hline Variáveis & Categoria & № de animais & Sororeagentes & Valor $p$ \\
\hline \multirow[t]{2}{*}{ Aborto } & Sim & 136 & $3(2,2 \%)$ & 0,39 \\
\hline & Não & 121 & $1(0,8 \%)$ & \\
\hline \multirow[t]{2}{*}{ Endometrite } & Sim & 6 & $0(0,0 \%)$ & - \\
\hline & Não & 251 & $4(1,6 \%)$ & \\
\hline \multirow[t]{2}{*}{ Malformação fetal } & Sim & 3 & $0(0,0 \%)$ & - \\
\hline & Não & 254 & $4(1,6 \%)$ & \\
\hline \multirow[t]{2}{*}{ Morte neonatal } & Sim & 34 & $0(0,0 \%)$ & - \\
\hline & Não & 223 & $4(1,8 \%)$ & \\
\hline \multirow[t]{2}{*}{ Nasc. de cordeiro fraco } & Sim & 30 & $0(0,0 \%)$ & - \\
\hline & Não & 227 & $4(1,8 \%)$ & \\
\hline \multirow[t]{2}{*}{ Natimortalidade } & Sim & 7 & $0(0,0 \%)$ & - \\
\hline & Não & 250 & $4(1,6 \%)$ & \\
\hline \multirow[t]{2}{*}{ Parto distócico } & Sim & 6 & $0(0,0 \%)$ & - \\
\hline & Não & 251 & $4(1,6 \%)$ & \\
\hline \multirow[t]{2}{*}{ Parto prematuro } & Sim & 3 & $0(0,0 \%)$ & - \\
\hline & Não & 254 & $4(1,6 \%)$ & \\
\hline \multirow[t]{2}{*}{ Prolapso uterino } & Sim & 2 & $0(0,0 \%)$ & - \\
\hline & Não & 255 & $4(1,6 \%)$ & \\
\hline \multirow[t]{2}{*}{ Repetição de cio } & Sim & 77 & $1(1,3 \%)$ & 0,83 \\
\hline & Não & 180 & $3(1,7 \%)$ & \\
\hline \multirow[t]{2}{*}{ Retenção de placenta } & Sim & 3 & $0(0,0 \%)$ & - \\
\hline & Não & 254 & $4(1,6 \%)$ & \\
\hline
\end{tabular}

Ref.: Parâmetro de referência na análise de significância Valores de $p \leq 0,1$ são estatisticamente significantes 


\subsubsection{Leptospirose}

Dentre os parâmetros listados na tabela 35 , submetidos à análise de significância em relação à leptospirose, apenas a presença de felídeos apresentou valor de $\mathrm{p}$ significante $(0,018)$.

Tabela 35 - Análise de significância (valor de p) entre animais sororeagentes a Leptospirose em relação ao sexo, raça, tipo de instalação, alimentação, sistema de criação, presença de outras espécies animais e tipo de monta - São Paulo - 2011

\begin{tabular}{|c|c|c|c|c|}
\hline Variável & Categoria & № de animais & Sororeagentes & Valor $p$ \\
\hline \multirow[t]{2}{*}{ Sexo } & Fêmea & 257 & $56(21,8 \%)$ & 0,28 \\
\hline & Macho & 37 & $11(29,7 \%)$ & \\
\hline \multirow{4}{*}{ Raça } & Dorper & 29 & $9(31,0 \%)$ & 0,27 \\
\hline & Lanados & 88 & $20(22,7 \%)$ & 0,85 \\
\hline & Mestiços & 20 & $4(20,0 \%)$ & 0,87 \\
\hline & Santa Inês & 157 & $34(21,7 \%)$ & Ref. \\
\hline \multirow[t]{2}{*}{ Instalações } & Com estábulo & 249 & $58(23,3 \%)$ & 0,73 \\
\hline & Sem estábulo & 43 & $9(20,9 \%)$ & \\
\hline \multirow[t]{5}{*}{ Alimentação } & Pastagem & 51 & $11(21,6 \%)$ & Ref. \\
\hline & Pastagem + & & & \\
\hline & concentrado & 110 & $15(16,7 \%)$ & 0,47 \\
\hline & $\begin{array}{l}\text { Pastagem + } \\
\text { concentrado + } \\
\text { silagem }\end{array}$ & 116 & $31(29,2 \%)$ & 0,31 \\
\hline & $\begin{array}{l}\text { Concentrado + } \\
\text { silagem }\end{array}$ & 47 & $10(21,3 \%)$ & 0,97 \\
\hline \multirow[t]{2}{*}{ Sis. de criação } & Intensivo & 80 & $22(27,5 \%)$ & 0,24 \\
\hline & Semi-intensivo & 214 & $45(21,0 \%)$ & Ref. \\
\hline \multicolumn{5}{|c|}{ Presença de outras espécies animais } \\
\hline & Bovinos & 59 & $15(25,4 \%)$ & 0,59 \\
\hline & Caninos & 183 & $43(23,5 \%)$ & 0,71 \\
\hline & Felinos & 192 & $52(27,1 \%)$ & 0,018 \\
\hline & Aves & 141 & $32(22,7 \%)$ & 0,97 \\
\hline
\end{tabular}




\begin{tabular}{lllll}
\hline Tipo de monta & Natural & 132 & $25(18,9 \%)$ & 0,16 \\
& Mista & 162 & $42(25,9 \%)$ & Ref. \\
\hline
\end{tabular}

Ref.: Parâmetro de referência na análise de significância

Valores de $p \leq 0,1$ são estatisticamente significantes

$\mathrm{Na}$ análise de fator de risco para a presença de felídeos no criatório e a incidência de animais sororeagentes a leptospirose, foi observado que criatórios que possuem felinos apresentam fator de risco de 2,15 de possuírem animais sororeagentes (Tabela 36).

Tabela 36 - Fator de risco entre a infecção por Leptospiras e a presença de felídeos em criatórios ovinos do estado de São Paulo - São Paulo - 2011

\begin{tabular}{lccc}
\hline & Valor $p$ & Odds ratio & Intervalo de confiança (95\%) \\
\hline Presença de felinos & 0,018 & 2,15 & $1,14-4,06$ \\
\hline
\end{tabular}

Dentre os parâmetros da tabela 37 , foi observada significância somente na manifestação de telangectasia da mucosa vaginal, no entanto como se observa na tabela 38, o valor do fator de risco foi de 0,25 , mostrando que animais sororeagentes a leptospirose tem menor chance de apresentarem esse sinal clínico na mucosa vaginal.

Tabela 37 - Análise de significância (valor de p) entre animais sororeagentes a Leptospiras em relação à presença ou não sinais clínicos no momento do exame ginecológico - São Paulo - 2011

\begin{tabular}{lcccc}
\hline Variáveis & Categoria & № de animais & Sororeagentes & Valor p \\
\hline Mucosa hipercorada & Sim & 46 & $11(23,9 \%)$ & 0,70 \\
& Não & 211 & $45(21,3 \%)$ & \\
Mucosa hipocorada & Sim & 13 & $5(38,5 \%)$ & 0,15 \\
& Não & 244 & $51(20,9 \%)$ & \\
Nódulos & Presente & 15 & $2(13,3 \%)$ & 0,42 \\
& Ausente & 242 & $54(22,3 \%)$ & \\
Petéquias & Presente & 5 & $1(20,0 \%)$ & 0,92 \\
\multirow{3}{*}{ Pústulas } & Ausente & 252 & $55(21,8 \%)$ & \\
& Presente & 2 & $1(50,0 \%)$ & 0,36 \\
Secreções & Ausente & 255 & $55(21,6 \%)$ & \\
\hline
\end{tabular}




\begin{tabular}{lcccc}
\hline & Ausente & 219 & $51(23,3 \%)$ & \\
Telangectasia & Presente & 28 & $2(7,1 \%)$ & 0,064 \\
& Ausente & 229 & $54(23,6 \%)$ & \\
Vesículas & Presente & 1 & $0(0,0 \%)$ & - \\
& Ausente & 256 & $56(21,9 \%)$ & \\
\hline
\end{tabular}

Ref.: Parâmetro de referência na análise de significância

Valores de $p \leq 0,1$ são estatisticamente significantes

Tabela 38 - Fator de risco entre infecção por Leptospiras e a presença de telangectasia da mucosa vaginal de ovinos criados no estado de São Paulo - São Paulo - 2011

\begin{tabular}{lccc}
\hline Sinal clínico & Valor $p$ & Odds ratio & Intervalo de confiança (95\%) \\
\hline Telangectasia & 0,064 & 0,25 & $0,06-1,08$ \\
\hline
\end{tabular}

A leptospirose se mostrou significante aos parâmetros do histórico reprodutivo relacionado a abortamento e endometrite, no entanto as interpretações foram diferentes (Tabela 39). No caso do abortamento $(p=0,046)$ a análise de fator de risco mostra que diminui o risco de abortamento quando um ovino é soropositivo a leptospiras $(\mathrm{OR}=0,54)$ (Tabela 40$)$, já a endometrite apresentou fator de risco positivo de 7,62 (Tabela 41).

Tabela 39 - Análise de significância (valor de p) entre animais sororeagentes a Leptospirose em relação à presença ou não de distúrbios reprodutivos no histórico de fêmeas ovinas São Paulo - 2011

\begin{tabular}{lcccc}
\hline Variáveis & Categoria & № de animais & Sororeagentes & Valor p \\
\hline Aborto & Sim & 136 & $23(16,9 \%)$ & 0,046 \\
& Não & 121 & $33(27,3 \%)$ & \\
Endometrite & $\operatorname{Sim}$ & 6 & $4(66,7 \%)$ & 0,021 \\
Malformação fetal & Não & 251 & $52(20,7 \%)$ & \\
Morte neonatal & Sim & 3 & $0(0,0 \%)$ & - \\
& Não & 254 & $56(22,0 \%)$ & \\
Nasc. de cordeiro fraco & Sim & 34 & $7(20,6 \%)$ & 0,86 \\
& Não & 223 & $49(22,0 \%)$ & \\
Natimortalidade & Sim & 30 & $7(23,3 \%)$ & 0,83 \\
& Não & 227 & $49(21,6 \%)$ & \\
& Sim & 7 & $3(42,9 \%)$ & 0,19 \\
\hline
\end{tabular}




\begin{tabular}{lcccc}
\hline Parto distócico & Sim & 6 & $2(33,3 \%)$ & 0,49 \\
& Não & 251 & $54(21,5 \%)$ & \\
Parto prematuro & Sim & 3 & $1(33,3 \%)$ & 0,63 \\
& Não & 254 & $55(21,7 \%)$ & \\
Prolapso uterino & Sim & 2 & $1(50,0 \%)$ & 0,36 \\
\multirow{2}{*}{ Repetição de cio } & Não & 255 & $55(21,6 \%)$ & \\
& Sim & 77 & $21(27,3 \%)$ & 0,17 \\
Retenção de placenta & Não & 180 & $35(19,4 \%)$ & \\
& Sim & 3 & $0(0,0 \%)$ & - \\
& Não & 254 & $56(22,0 \%)$ & \\
\hline
\end{tabular}

Ref.: Parâmetro de referência na análise de significância

Valores de $p \leq 0,1$ são estatisticamente significantes

Tabela 40 - Fator de risco entre infecção por Leptospiras e a ocorrência de abortamentos em ovinos criados no estado de São Paulo - São Paulo - 2011

\begin{tabular}{lccc}
\hline Histórico reprodutivo & Valor $\mathrm{p}$ & Odds ratio & Intervalo de confiança (95\%) \\
\hline Aborto & 0,046 & 0,54 & $0,30-0,99$ \\
\hline
\end{tabular}

Tabela 41 - Fator de risco entre infecção por Leptospiras e a presença de endometrite em ovinos criados no estado de São Paulo - São Paulo - 2011

\begin{tabular}{llcc}
\hline Histórico reprodutivo & Valor $\mathrm{p}$ & Odds ratio & Intervalo de confiança (95\%) \\
\hline Endometrite & 0,021 & 7,62 & $1,36-42,72$ \\
\hline
\end{tabular}

\subsubsection{Neospora caninum}

Assim como a toxoplasmose a neosporose apresentou cinco categorias com valor de $p$ significante, sendo elas; sexo $(p=0,031)$, ovinos de raças lanadas $(p=0,085)$, instalações $(p<0,001)$, alimentação a base de pastagem e concentrado $(p=0,057)$ e sistema de criação $(p<0,001)$ (Tabela 42). 
Tabela 42 - Análise de significância (valor de p) entre animais sororeagentes a Neospora caninum em relação ao sexo, raça, tipo de instalação, alimentação, sistema de criação, presença de outras espécies animais e tipo de monta - São Paulo - 2011

\begin{tabular}{|c|c|c|c|c|}
\hline Variável & Categoria & $\begin{array}{c}\text { Número de } \\
\text { animais }\end{array}$ & Sororeagentes & Valor $p$ \\
\hline \multirow[t]{2}{*}{ Sexo } & Fêmea & 257 & $52(20,2 \%)$ & 0,031 \\
\hline & Macho & 37 & $1(2,7 \%)$ & Ref. \\
\hline \multirow[t]{4}{*}{ Raça } & Dorper & 29 & $0(0,0 \%)$ & - \\
\hline & Lanados & 88 & $24(27,3 \%)$ & 0,085 \\
\hline & Mestiços & 20 & $1(5,0 \%)$ & 0,18 \\
\hline & Santa Inês & 157 & 28 (17,8\%) & \\
\hline \multirow[t]{2}{*}{ Instalações } & Com estábulo & 249 & $29(11,6 \%)$ & Ref. \\
\hline & Sem estábulo & 43 & $24(55,8 \%)$ & $<0,001$ \\
\hline \multirow[t]{4}{*}{ Alimentação } & Pastagem & 51 & $6(11,8 \%)$ & Ref. \\
\hline & $\begin{array}{l}\text { Pastagem + } \\
\text { concentrado }\end{array}$ & 110 & $23(25,6 \%)$ & 0,057 \\
\hline & $\begin{array}{l}\text { Pastagem + } \\
\text { concentrado + } \\
\text { silagem }\end{array}$ & 116 & $22(20,8 \%)$ & 0,17 \\
\hline & $\begin{array}{l}\text { Concentrado + } \\
\text { silagem }\end{array}$ & 47 & $2(4,3 \%)$ & 0,19 \\
\hline \multirow[t]{2}{*}{ Sist. de criação } & Intensivo & 80 & $3(3,8 \%)$ & Ref. \\
\hline & Semi-intensivo & 214 & $50(23,4 \%)$ & 0,001 \\
\hline \multicolumn{5}{|c|}{ Presença de outras espécies animais } \\
\hline & Bovinos & 59 & $8(13,6 \%)$ & 0,32 \\
\hline & Caninos & 183 & $37(20,2 \%)$ & 0,21 \\
\hline & Felinos & 192 & $32(16,7 \%)$ & 0,41 \\
\hline & Aves & 141 & $22(15,6 \%)$ & 0,30 \\
\hline \multirow[t]{2}{*}{ Tipo de monta } & Natural & 132 & $22(16,7 \%)$ & 0,58 \\
\hline & Mista & 162 & 31 (19,5\%) & \\
\hline
\end{tabular}

Ref.: Parâmetro de referência na análise de significância

Valores de $p \leq 0,1$ são estatisticamente significantes 
Segundo analise de fator de risco das amostras que reagiram a Neospora caninum nesse estudo, fêmeas possuem 9,13 mais chances de se infestarem que machos ovinos (Tabela 43).

Tabela 43 - Fator de risco entre infecção por Neospora caninum e o sexo de ovinos de criatórios do estado de São Paulo - São Paulo - 2011

\begin{tabular}{lccc}
\hline Sexo & Valor $p$ & Odds ratio & Intervalo de confiança (95\%) \\
\hline Fêmea & 0,031 & 9,13 & $1,22-68,16$ \\
Macho & & & \\
\hline
\end{tabular}

Quanto às raças, as de ovinos lanados apresentaram maior risco de contaminação ao parasita $(\mathrm{OR}=1,73)$ em relação às outras categorias de raças (Tabela 44).

\begin{tabular}{lccc} 
Tabela 44 & $-\begin{array}{c}\text { Fator de risco entre infecção por } \\
\text { criatórios do estado de São Paulo - São Paulo - 2011 }\end{array}$ \\
\hline Raça & Valor p & Odds ratio & Intervalo de confiança (95\%) \\
\hline Dorper & - & - & $0,93-3,22$ \\
Lanados & 0,085 & 1,73 & \\
Mestiços & 0,176 & - & \\
Santa Inês & Ref. & & \\
\hline
\end{tabular}

Ref.: Parâmetro de referência na análise de significância

Ovinos de criatórios onde os mesmos não eram estabulados em nenhum momento do dia, ficando mais expostos a pastagem, apresentaram risco 9,58 vezes maior (Tabela 45).

$\begin{aligned} & \text { Tabela } 45 \\
& \text { - Fator de risco entre infecção por } \\
& \text { estábulos em criatórios ovinos do estado de São Paulo - São Paulo - 2011 }\end{aligned}$
\begin{tabular}{lccc}
\hline Instalações & Valor p & Odds ratio & Intervalo de confiança (95\%) \\
\hline Sem estábulo & $<0,001$ & 9,58 & $4,19-19,60$ \\
Com Estábulo & & & \\
\hline
\end{tabular}

Entre os tipos de alimentação pastagem, pastagem, concentrado e silagem e concentrado e silagem não houve relação de significância, somente a categoria fornecimento de pastagem e concentrado apresentou valor de $p$ significante 
$(P=0,057)$ e fator de risco de 2,58 em relação ao fornecimento de pastagem (Tabela 46).

Tabela 46 - Fator de risco entre infecção por Neospora caninum e o tipo de alimentação fornecida em criatórios ovinos do estado de São Paulo - São Paulo - 2011

\begin{tabular}{lccc}
\hline Alimentação & Valor p & Odds ratio & Intervalo de confiança (95\%) \\
\hline Pastagem & Ref. & - & - \\
Pastagem + & 0,057 & 2,58 & $0,97-6,82$ \\
$\begin{array}{l}\text { concentrado } \\
\text { Pastagem + }\end{array}$ & 0,174 & 1,96 & $0,74-5,20$ \\
$\begin{array}{l}\text { concentrado + silagem } \\
\text { Concentrado + silagem }\end{array}$ & 0,193 & 0,333 & $0,06-1,74$ \\
\hline
\end{tabular}

Ref.: Parâmetro de referência na análise de significância

O sistema de criação semi-intensivo se mostrou mais susceptível a infecção por Neospora caninum, apresentando fator de risco de 7,83 em relação ao sistema intensivo (Tabela 47).

Tabela 47 - Fator de risco entre infecção por Neospora caninum e o sistema de criação de criatórios ovinos do estado de São Paulo - São Paulo - 2011

\begin{tabular}{lccc}
\hline Sistema de criação & Valor $\mathrm{p}$ & Odds ratio & Intervalo de confiança (95\%) \\
\hline Semi-intensivo & 0,001 & 7,83 & $2,37-25,88$ \\
Intensivo & & & \\
\hline
\end{tabular}

Não foi observada relação entre animais sororeagentes a Neospora caninum e sinais clínicos observados no momento do exame ginecológico. Somente a categoria presença de secreção vaginal apresentou valor de $p$ significante $(0,018)$ (Tabela 48), no entanto ao realizarmos a análise de fator de risco observa-se que animais reagentes possuem menor risco de apresentar esse sinal clínico $(O R=0,09)$ (Tabela 49). Isso pode ser associado aos dados em relação ao quadro de abortamento descrito na tabela 50 onde foi obtido valor de $p$ significante $(0,044)$ e com a realização da análise de fator de risco foi notado queda do risco de abortamento $(\mathrm{OR}=0,53)$ (Tabela 51). 
Tabela 48 - Análise de significância (valor de p) entre animais sororeagentes a Neospora caninum em relação à presença ou não de sinais clínicos no momento do exame ginecológico São Paulo - 2011

\begin{tabular}{lcccc}
\hline Variáveis & Categoria & $\begin{array}{c}\text { Número de } \\
\text { animais }\end{array}$ & Sororeagentes & Valor p \\
\hline Mucosa hipercorada & Sim & 46 & $5(10,9 \%)$ & 0,09 \\
& Não & 211 & $47(22,3 \%)$ & \\
Mucosa hipocorada & Sim & 13 & $4(30,8 \%)$ & 0,34 \\
& Não & 244 & $48(19,7 \%)$ & \\
Nódulos & Presente & 15 & $2(13,3 \%)$ & 0,98 \\
Petéquias & Ausente & 242 & $51(20,2 \%)$ & \\
& Presente & 5 & $1(20,0 \%)$ & 0,99 \\
Pústulas & Ausente & 252 & $52(20,4 \%)$ & \\
\multirow{2}{*}{ Secreções } & Presente & 2 & $0(0,0 \%)$ & - \\
& Ausente & 255 & $51(23,3 \%)$ & \\
Telangectasia & Presente & 38 & $1(2,6 \%)$ & 0,018 \\
& Ausente & 219 & $51(23,3 \%)$ & \\
Vesículas & Presente & 28 & $7(25,0 \%)$ & 0,51 \\
& Ausente & 229 & $45(19,7 \%)$ & \\
& Presente & 1 & $0(0,0 \%)$ & - \\
\hline
\end{tabular}

Ref.: Parâmetro de referência na análise de significância

Valores de $p \leq 0,1$ são estatisticamente significantes

Tabela 49 - Fator de risco entre infecção por Neospora caninum e a presença de secreção uterina em ovinos criados no estado de São Paulo - São Paulo - 2011

\begin{tabular}{lccc}
\hline Sinal clínico & Valor $p$ & Odds ratio & Intervalo de confiança (95\%) \\
\hline Secreções & 0,018 & 0,09 & $0,01-0,67$ \\
\hline
\end{tabular}

Tabela 50 - Análise de significância (valor de p) entre animais sororeagentes a Neospora caninum em relação à presença ou não de distúrbios reprodutivos no histórico de fêmeas ovinas - São Paulo - 2011

\begin{tabular}{lcccc}
\hline Variáveis & Categoria & $\begin{array}{c}\text { Número de } \\
\text { animais }\end{array}$ & Sororeagentes & Valor p \\
\hline Aborto & Sim & 136 & $21(15,4 \%)$ & 0,044 \\
& Não & 121 & $31(25,6 \%)$ & \\
Endometrite & Sim & 6 & $0(0,0 \%)$ & - \\
\hline
\end{tabular}




\begin{tabular}{|c|c|c|c|c|}
\hline & Não & 251 & $52(20,3 \%)$ & \\
\hline \multirow[t]{2}{*}{ Malformação fetal } & Sim & 3 & $0(0,0 \%)$ & - \\
\hline & Não & 254 & $52(20,5 \%)$ & \\
\hline \multirow[t]{2}{*}{ Morte neonatal } & Sim & 34 & $9(26,5 \%)$ & 0,33 \\
\hline & Não & 223 & $43(19,3 \%)$ & \\
\hline \multirow[t]{2}{*}{ Nasc. de cordeiro fraco } & Sim & 30 & $7(23,3 \%)$ & 0,65 \\
\hline & Não & 227 & $45(19,8 \%)$ & \\
\hline \multirow{2}{*}{ Natimortalidade } & Sim & 7 & $0(0,0 \%)$ & - \\
\hline & Não & 250 & $52(20,8 \%)$ & \\
\hline \multirow[t]{2}{*}{ Parto distócico } & Sim & 6 & $0(0,0 \%)$ & - \\
\hline & Não & 251 & $52(20,7 \%)$ & \\
\hline \multirow[t]{2}{*}{ Parto prematuro } & Sim & 3 & $0(0,0 \%)$ & - \\
\hline & Não & 254 & $52(20,5 \%)$ & \\
\hline \multirow[t]{2}{*}{ Prolapso uterino } & Sim & 2 & $0(0,0 \%)$ & - \\
\hline & Não & 255 & $52(20,4 \%)$ & \\
\hline \multirow[t]{2}{*}{ Repetição de cio } & Sim & 77 & $21(27,3 \%)$ & 0,068 \\
\hline & Não & 180 & $31(17,2 \%)$ & \\
\hline \multirow[t]{2}{*}{ Retenção de placenta } & Sim & 3 & $0(0,0 \%)$ & - \\
\hline & Não & 254 & $52(20,5 \%)$ & \\
\hline
\end{tabular}

Ref.: Parâmetro de referência na análise de significância

Valores de $p \leq 0,1$ são estatisticamente significantes

Tabela 51 - Fator de risco entre infecção por Neospora caninum e a ocorrência de abortamentos em ovinos criados no estado de São Paulo - São Paulo - 2011

\begin{tabular}{lccc}
\hline Histórico Reprodutivo & Valor $\mathrm{p}$ & Odds ratio & Intervalo de confiança (95\%) \\
\hline Aborto & 0,044 & 0,53 & $0,29-0,98$ \\
\hline
\end{tabular}

A única alteração de cunho reprodutivo que apresentou fator de risco associado a animais sororeagentes a neosporose foi à repetição de cio com valor de $p=0,068$ e OR de 1,80 (Tabelas 50 e 52).

Tabela 52 - Fator de risco entre infecção por Neospora caninum e a ocorrência de repetição de cio em ovinos criados no estado de São Paulo - São Paulo - 2011

\begin{tabular}{lccc}
\hline Histórico Reprodutivo & Valor $\mathrm{p}$ & Odds ratio & Intervalo de confiança (95\%) \\
Repetição de Cio & 0,068 & 1,80 & $0,96-3,40$ \\
\hline
\end{tabular}




\subsubsection{Toxoplasma gondii}

Cinco parâmetros relacionados a características do criatório apresentaram valor de $\mathrm{p}$ significante no caso de animais sororeagentes para toxoplasmose (Tabela $53)$.

Quanto à raça foi observado para a categoria de ovinos lanados $p=0,06$, enquanto as outras categorias não apresentaram valor significante $(p=0,68$ e $\mathrm{p}=0,66)$.

A presença ou ausência de estábulos no criatório apresentou $p=0,087$. Em relação ao tipo de alimento fornecido utilizando como referência alimentação a base de pasto, a categoria onde é fornecido pastagem, concentrado e silagem apresentou $p<0,001$.

$\mathrm{Na}$ categoria de presença de outras espécies animais no criatório, duas espécies foram significantes, a presença de felinos $(p=0,087)$ e de aves $(p=0,001)$, enquanto as presenças de bovinos e canídeos não apresentaram significância.

Por último, observa-se significância em relação ao tipo de cobertura onde o valor de $\mathrm{p}$ entre a monta natural e a monta mista foi de 0,002 .

Tabela 53 - Análise de significância (valor de p) entre animais sororeagentes a Toxoplasma gondii em relação ao sexo, raça, tipo de instalação, alimentação, sistema de criação, presença de outras espécies animais e tipo de monta - São Paulo - 2011

\begin{tabular}{llccc}
\hline Variáveis & \multicolumn{1}{c}{ Categoria } & № de animais & Sororeagentes & Valor $p$ \\
\hline Sexo & Fêmea & 257 & $79(30,7 \%)$ & 0,43 \\
\multirow{4}{*}{ Raça } & Macho & 37 & $9(24,3 \%)$ & \\
& Dorper & 29 & $9(31,0 \%)$ & 0,68 \\
& Lanados & 88 & $16(18,2 \%)$ & 0,006 \\
& Mestiços & 20 & $8(40,0 \%)$ & 0,66 \\
\multirow{4}{*}{ Instalações } & Santa Inês & 157 & $55(35,0 \%)$ & Ref. \\
& Com estábulo & 249 & $79(31.7 \%)$ & 0,087 \\
& Sem Estábulo & 43 & $8(18.3 \%)$ & \\
& Pastagem & 51 & $22(43,1 \%)$ & Ref. \\
& Pastagem + & 110 & $37(41,1 \%)$ & 0,82 \\
& concentrado & & & \\
\hline
\end{tabular}




\begin{tabular}{llccc}
\hline & $\begin{array}{l}\text { Pastagem + } \\
\text { concentrado + } \\
\text { silagem }\end{array}$ & 116 & $16(15,1 \%)$ & $<0,001$ \\
Concentrado + & 47 & $13(27,7 \%)$ & 0,11 \\
silagem & & & \\
Sis. de criação & Intensivo & 80 & $20(25,0 \%)$ & 0,26 \\
& Semi-intensivo & 214 & $68(31,8 \%)$ & \\
Presença de outras espécies animais & & & \\
Bovinos & 59 & $19(32,2 \%)$ & 0,67 \\
& Caninos & 183 & $58(31,7 \%)$ & 0,40 \\
Felinos & 192 & $51(26,65)$ & 0,087 \\
Tipo de monta & 141 & $55(39,7 \%)$ & 0,001 \\
& Natural & 132 & $52(39,4 \%)$ & 0,002 \\
& Mista & 162 & $36(22,2 \%)$ & \\
\hline
\end{tabular}

Ref.: Parâmetro de referência na análise de significância

Valores de $p \leq 0,1$ são estatisticamente significantes

Realizando a análise de fator de risco observa-se que utilizando a raça Santa Inês como referência, o fator de risco da categoria ovinos de raças lanadas torna-se negativo $(O R=0,41)$, ou seja, esses ovinos apresentaram menor risco de contraírem o parasita (Tabela 54). Ao se realizar análise de fator de risco utilizando a categoria raças de ovinos lanados como referência (Tabela 55) obteve-se resultado semelhante. Em ordem decrescente, mestiços, a raça Santa Inês e a raça Dorper apresentaram maior risco de contaminação.

\begin{tabular}{lccc} 
Tabela 54 & $\begin{array}{l}\text { Fator de risco entre infecção por Toxoplasma gondii e a raça de ovinos de } \\
\text { criatórios do estado de São Paulo - São Paulo - 2011 }\end{array}$ \\
\hline Raça & Valor $p$ & Odds ratio & Intervalo de confiança (95\%) \\
\hline Dorper & 0,677 & - & \\
Lanados & 0,006 & 0,41 & $0,22-0,78$ \\
Mestiços & 0,663 & - & \\
Santa Inês & Ref. & & \\
\hline
\end{tabular}

Ref.: Parâmetro de referência na análise de significância

Valores de $p \leq 0,1$ são estatisticamente significantes 
Tabela 55 - Fator de risco entre infecção por Toxoplasma gondii e a raça de ovinos de criatórios do estado de São Paulo, utilizando ovinos de raças lanadas como referência - São Paulo - 2011

\begin{tabular}{lccc}
\hline Raça & Valor $\mathrm{p}$ & Odds ratio & Intervalo de confiança (95\%) \\
\hline Dorper & 0,148 & 2,03 & $0,78-5,26$ \\
Lanados & Ref. & - & - \\
Mestiços & 0,040 & 3,00 & $1,05-8,54$ \\
Santa Inês & 0,006 & 2,43 & $1,29-4,57$ \\
\hline
\end{tabular}

Ref.: Parâmetro de referência na análise de significância

Valores de $p \leq 0,1$ são estatisticamente significantes

$\mathrm{Na}$ análise de fator de risco, ovinos de propriedades que possuem estábulos e com isso em algum período permanecem concentrados no recinto, apresentaram fator de risco de 2,03 em relação a criatórios onde os animais permaneciam exclusivamente a pasto (Tabela 56).

Tabela 56 - Fator de risco entre infecção por Toxoplasma gondii e a presença ou não de estábulos em criatórios ovinos do estado de São Paulo - São Paulo - 2011

\begin{tabular}{lccc}
\hline Instalações & Valor $p$ & Odds ratio & Intervalo de confiança (95\%) \\
\hline Com estábulo & 0,087 & 2,03 & $0,90-4,58$ \\
Sem estábulo & & & \\
\hline
\end{tabular}

Em relação ao valor de $\mathrm{p}<0,001$ do ítem alimentação e categoria fornecimento de pastagem, concentrado e silagem, ao observar-se a análise de fator de risco, essa categoria apresentou menor risco de contaminação pelo parasita $(\mathrm{OR}=0,23)$ (Tabela 57). Ao realizar a análise de fator de risco utilizando essa categoria como referência, foi observado que os três itens juntos, (pasto, concentrado e silo), apresentaram menor risco de contaminação. A introdução de pastagem na alimentação e a retirada de silagem aumentam o risco de contaminação, com valores de 4,27 e 3,58 para pastagem e pastagem e concentrado como pode ser observado na tabela 57 . No momento que se retira a pastagem da alimentação e a substitui por silagem o fator de risco diminui $(\mathrm{OR}=2,15)$ (Tabela 58).

Analisando esses dados, ao diminuir o fornecimento de pasto e aumentar os outros tipos de alimentos como o concentrado e a silagem o fator de risco de contaminação ao Toxoplasma gondii decresce. 
Tabela 57 - Fator de risco entre infecção por Toxoplasma gondii e tipo de alimentação fornecida em criatórios ovinos do estado de São Paulo - São Paulo - 2011

\begin{tabular}{lccc}
\hline Alimentação & Valor $p$ & Odds ratio & Intervalo de confiança (95\%) \\
\hline Pastagem & Ref. & - & \\
Pastagem + concentrado & 0,815 & 0,92 & $0,46-1,84$ \\
Pastagem + concentrado & $<0,001$ & 0,23 & $0,11-0,51$ \\
+ silagem & & & \\
Concentrado + silagem & 0,112 & 0,50 & $0,22-1,17$ \\
\hline
\end{tabular}

Ref.: Parâmetro de referência na análise de significância

Valores de $p \leq 0,1$ são estatisticamente significantes

Tabela 58 - Fator de risco entre infecção por Toxoplasma gondii e tipo de alimentação fornecida em criatórios ovinos do estado de São Paulo, utilizando a categoria tipo de alimentação, Pastagem + Concentrado + Silagem como referência - São Paulo - 2011

\begin{tabular}{lccc}
\hline Alimentação & Valor $p$ & Odds ratio & Intervalo de confiança (95\%) \\
\hline Pastagem & $<0,001$ & 4,27 & $1,98-9,20$ \\
Pastagem + concentrado & $<0,001$ & 3,93 & $1,99-7,73$ \\
Pastagem + concentrado & Ref. & - & - \\
+ silagem & & & $0,94-4,94$ \\
Concentrado + silagem & 0,071 & 2,15 & \\
\hline
\end{tabular}

Ref.: Parâmetro de referência na análise de significância

Valores de $p \leq 0,1$ são estatisticamente significantes

A presença de aves em criatórios ovinos apresentou aumento de 2,49 vezes o risco de contaminação pela bactéria, enquanto a presença de felinos, que são os transmissores da enfermidade, apresentou queda no risco de infecção $(\mathrm{OR}=0,64)$ (Tabela 59). Com esse dado foi analisado o risco de propriedades que não possuem felinos e o que é observado é que sua ausência nos criatórios aumenta em 1,57 vezes o risco de transmissão, com valor de $\mathrm{p}=0,085$ (Tabela 60 e 61).

Tabela 59 - Fator de risco entre infecção por Toxoplasma gondii e a presença de felídeos e aves em criatórios ovinos do estado de São Paulo - São Paulo - 2011

\begin{tabular}{lccc}
\hline $\begin{array}{l}\text { Presença de outras } \\
\text { espécies animais }\end{array}$ & Valor $p$ & Odds ratio & Intervalo de confiança (95\%) \\
\hline Felinos & 0,087 & 0,64 & $0,38-1,06$ \\
Aves & 0,001 & 2,49 & $1,49-4,17$ \\
\hline
\end{tabular}


Tabela 60 - Análise de significância (valor de p) entre animais sororeagentes a Toxoplasma gondii em relação à ausência de felídeos em criatórios de ovinos do estado de São Paulo São Paulo - 2011

\begin{tabular}{lccc}
\hline Variáveis & Número de animais & Sororeagentes & Valor $\mathrm{p}$ \\
\hline Ausência de Felinos & 102 & $37(36,6)$ & 0,085 \\
\hline
\end{tabular}

Tabela 61 - Fator de risco entre infecção por Toxoplasma gondii e a ausência de felídeos em criatórios ovinos do estado de São Paulo - São Paulo - 2011

\begin{tabular}{llll}
\hline Ausência de outras & Valor $p$ & Odds ratio Intervalo de confiança (95\%) \\
espécies animais & & & \\
\hline
\end{tabular}

\begin{tabular}{llll}
\hline Felinos & 0,085 & 1,57 & $0,94-2,64$
\end{tabular}

Ao comparamos os criatórios que utilizam exclusivamente a monta natural, menos tecnificados, com os que utilizam também inseminação artificial e/ou transferência de embriões, o fator de risco para transmissão de toxoplasmose foi 2,28 vezes maior (Tabela 62).

Tabela 62 - Fator de risco entre infecção por Toxoplasma gondii e o sistema de reprodução utilizado em criatórios ovinos do estado de São Paulo - São Paulo - 2011

\begin{tabular}{lccc}
\hline Tipo de monta & Valor $\mathrm{p}$ & Odds ratio & Intervalo de confiança (95\%) \\
\hline Natural & 0,002 & 2,28 & $1,37-3,79$ \\
Mista & & & \\
\hline
\end{tabular}

$\mathrm{Na}$ análise de significância dos sinais clínicos observados durante o exame ginecológico, nenhuma categoria apresentou valor de $\mathrm{p}$ significativo quando relacionado com as amostras de Toxoplasma gondii (Tabela 63).

Tabela 63 - Análise de significância (valor de p) entre animais sororeagentes a Toxoplasma gondii em relação à presença ou não de sinais clínicos no momento do exame ginecológico São Paulo - 2011

\begin{tabular}{lcccc}
\hline Variáveis & Categoria & № de animais & Sororeagentes & Valor p \\
\hline Mucosa hipercorada & Sim & 46 & $11(23,9 \%)$ & 0,27 \\
& Não & 211 & $68(32,2 \%)$ & \\
Mucosa hipocorada & Sim & 13 & $4(30,8 \%)$ & 0,99 \\
& Não & 244 & $75(30,7 \%)$ & \\
Nódulos & Presente & 15 & $6(40,0 \%)$ & 0,43 \\
& Ausente & 242 & $73(30,2 \%)$ & \\
Petéquias & Presente & 5 & $3(60,0 \%)$ & 0,18 \\
\hline
\end{tabular}




\begin{tabular}{lcccc}
\hline \multirow{2}{*}{ Pústulas } & Ausente & 252 & $76(30,2 \%)$ & \\
& Presente & 2 & $0(0,0 \%)$ & - \\
Secreções & Ausente & 255 & $79(31,0 \%)$ & \\
\multirow{2}{*}{ Telangectasia } & Presente & 38 & $12(31,6 \%)$ & 0,90 \\
& Ausente & 219 & $67(30,6 \%)$ & \\
Vesículas & Presente & 28 & $9(32,1 \%)$ & 0,87 \\
& Ausente & 229 & $70(30,6 \%)$ & \\
& Presente & 1 & $1(100 \%)$ & - \\
\hline
\end{tabular}

Ref.: Parâmetro de referência na análise de significância

Valores de $p \leq 0,1$ são estatisticamente significantes

Valores de $\mathrm{p}$ significantes foram observados na categoria de abortamentos e repetição de cio em relação à toxoplasmose ovina com valores de $p$ de 0,094 e 0,025 respectivamente (Tabela 64 ).

Tabela 64 - Análise de significância (valor de p) entre animais sororeagentes a Toxoplasma gondii em relação à presença ou não de distúrbios reprodutivos no histórico de fêmeas ovinas São Paulo - 2011

\begin{tabular}{lcccc}
\hline Variáveis & Categoria & No de animais & Sororeagentes & Valor p \\
\hline Aborto & Sim & 136 & $48(35,3 \%)$ & 0,094 \\
Endometrite & Não & 121 & $31(25,6 \%)$ & \\
Sim & 6 & $1(16,7 \%)$ & 0,46 \\
Malformação fetal & Não & 251 & $78(31,1 \%)$ & \\
Mim & 3 & $1(33,3 \%)$ & 0,92 \\
Norte neonatal & Simo & 254 & $78(30,7 \%)$ & \\
Nascimento de cordeiro & Não & 223 & $11(32,4 \%)$ & 0,83 \\
fraco & & $68(30,5 \%)$ & \\
& Sim & 30 & $7(23,3 \%)$ & 0,35 \\
Natimortalidade & Não & 227 & $72(31,7 \%)$ & \\
& Sim & 7 & $2(28,6 \%)$ & 0,90 \\
Parto distócico & Não & 250 & $77(30,8 \%)$ & \\
& Sim & 6 & $2(33,3 \%)$ & 0,89 \\
& Não & 251 & $77(30,7 \%)$ & \\
\hline
\end{tabular}




\begin{tabular}{lcccc}
\hline Parto prematuro & Sim & 3 & $2(66,6 \%)$ & 0,22 \\
& Não & 254 & $77(30,3 \%)$ & \\
Prolapso uterino & Sim & 2 & $0(0,0 \%)$ & - \\
& Não & 255 & $79(31,0 \%)$ & \\
Repetição de cio & Sim & 77 & $16(20,8 \%)$ & 0,025 \\
& Não & 180 & $63(35,0 \%)$ & \\
Retenção de placenta & Sim & 3 & $0(0,0 \%)$ & - \\
& Não & 254 & $79(31,1 \%)$ & \\
\hline
\end{tabular}

Ref.: Parâmetro de referência na análise de significância

Valores de $p \leq 0,1$ são estatisticamente significantes

Segundo a tabela 65, animais sororeagentes a Toxoplasma gondii possuíam fator de risco de 1,58 vezes de apresentarem quadro de abortamento, enquanto a tabela 66 demonstra diminuição do risco de repetição de cio em animais reagentes $(\mathrm{OR}=0,49)$.

Tabela 65 - Fator de risco entre infecção por Toxoplasma gondii e a ocorrência de abortamentos em ovinos criados no estado de São Paulo - São Paulo - 2011

\begin{tabular}{lccc}
\hline Histórico Reprodutivo & Valor $p$ & Odds ratio & Intervalo de confiança (95\%) \\
\hline Aborto & 0,094 & 1,58 & $0,92-2,71$ \\
\hline
\end{tabular}

Tabela 66 - Fator de risco entre infecção por Toxoplasma gondii e a ocorrência de repetição de cio em ovinos criados no estado de São Paulo - São Paulo - 2011

Histórico Reprodutivo Valor p Odds ratio Intervalo de confiança (95\%)

\begin{tabular}{llll}
\hline Repetição de Cio & 0,025 & 0,49 & $0,26-0,92$
\end{tabular}

\subsubsection{Campilobacter}

Não foi observado nenhum parâmetro com valor significante entre ovinos com isolamento de campilobacter em amostras fecais e o sexo, raça, tipo de instalação, alimentação, sistema de criação, presença de outras espécies animais e tipo de monta. (Tabela 67) 
Tabela 67 - Análise de significância (valor de p) entre ovinos com isolamento de Campylobacter spp. em amostras fecais em relação ao sexo, raça, tipo de instalação, alimentação, sistema de criação, presença de outras espécies animais e tipo de monta - São Paulo - 2011

\begin{tabular}{|c|c|c|c|c|}
\hline Variável & Categoria & № de animais & Isolamentos & Valor $p$ \\
\hline \multirow[t]{2}{*}{ Sexo } & Fêmea & 255 & $9(3,5 \%)$ & 0,80 \\
\hline & Macho & 19 & $1(5,3 \%)$ & \\
\hline \multirow[t]{4}{*}{ Raça } & Dorper & 25 & $0(0,0 \%)$ & - \\
\hline & Lanados & 74 & $0(0,0 \%)$ & 0,99 \\
\hline & Mestiços & 19 & $1(5,0 \%)$ & 0,89 \\
\hline & Santa Inês & 155 & $9(5,8 \%)$ & Ref. \\
\hline \multirow[t]{2}{*}{ Instalações } & Com estábulo & 229 & $10(23,3 \%)$ & - \\
\hline & Sem estábulo & 43 & $0(0,0 \%)$ & \\
\hline \multirow[t]{6}{*}{ Alimentação } & Pastagem & 51 & $1(2,0 \%)$ & Ref. \\
\hline & Pastagem + & & & \\
\hline & concentrado & 84 & $5(6,0 \%)$ & 0,33 \\
\hline & Pastagem + & & & \\
\hline & $\begin{array}{l}\text { concentrado + } \\
\text { silagem }\end{array}$ & 92 & $1(1,1 \%)$ & 0,60 \\
\hline & $\begin{array}{l}\text { Concentrado + } \\
\text { silagem }\end{array}$ & 47 & $3(6,5 \%)$ & 0,30 \\
\hline \multirow[t]{2}{*}{ Sist. de criação } & Intensivo & 80 & $3(3,8 \%)$ & 0,84 \\
\hline & Semi-intensivo & 194 & $7(3,6 \%)$ & \\
\hline \multicolumn{5}{|c|}{ Presença de outras espécies animais } \\
\hline & Bovinos & 44 & $0(0,0 \%)$ & - \\
\hline & Caninos & 168 & $8(4,8 \%)$ & 0,25 \\
\hline & Felinos & 177 & $8(4,5 \%)$ & 0,33 \\
\hline & Aves & 125 & $5(4,0 \%)$ & 0,90 \\
\hline \multirow[t]{2}{*}{ Tipo de monta } & Natural & 130 & $6(4,6 \%)$ & 0,34 \\
\hline & Mista & 144 & $4(2,8 \%)$ & \\
\hline
\end{tabular}

Ref.: Parâmetro de referência na análise de significância

Valores de $p \leq 0,1$ são estatisticamente significantes

No exame ginecológico a presença de petéquias na mucosa vaginal apresentou $p$ de 0,084 (Tabela 68) e fator de risco de 7,63 de se manifestar nos animais com isolamento fecal positivo (Tabela 69). 
Tabela 68 - Análise de significância (valor de p) entre ovinos com isolamento de Campylobacter spp. em amostras fecais em relação à presença ou não sinais clínicos no momento do exame ginecológico - São Paulo - 2011

\begin{tabular}{lcccc}
\hline Variáveis & Categoria & № de animais & Isolamentos & Valor $p$ \\
\hline Mucosa hipercorada & Sim & 46 & $1(2,2 \%)$ & 0,59 \\
& Não & 209 & $8(3,8 \%)$ & \\
Mucosa hipocorada & Sim & 13 & $1(7,7 \%)$ & 0,41 \\
& Não & 242 & $8(3,3 \%)$ & \\
Nódulos & Presente & 15 & $0(0,0 \%)$ & - \\
Petéquias & Ausente & 240 & $8(3,8 \%)$ & \\
& Presente & 5 & $1(20,0 \%)$ & 0,084 \\
Pústulas & Ausente & 250 & $8(3,2 \%)$ & \\
& Presente & 2 & $0(0,0 \%)$ & - \\
Secreções & Ausente & 253 & $9(3,6 \%)$ & \\
& Presente & 38 & $2(5,3 \%)$ & 0,53 \\
Telangectasia & Ausente & 217 & $7(3,2 \%)$ & \\
& Presente & 28 & $0(0,0 \%)$ & - \\
Vesículas & Ausente & 227 & $9(4,0 \%)$ & \\
& Presente & 1 & $0(0,0 \%)$ & - \\
& Ausente & 254 & $9(3,5 \%)$ & \\
\hline
\end{tabular}

Ref.: Parâmetro de referência na análise de significância

Valores de $p \leq 0,1$ são estatisticamente significantes

Tabela 69 - Fator de risco entre ovinos com isolamento de Campylobacter spp. em amostras fecais e a presença de petéquias na mucosa vaginal de ovinos criados no estado de São Paulo - São Paulo - 2011

\begin{tabular}{lccc}
\hline Sinal clínico & Valor $p$ & Odds ratio & Intervalo de confiança (95\%) \\
\hline Petéquias & 0,084 & 7,63 & $0,76-76,18$ \\
\hline
\end{tabular}

No histórico de alterações reprodutivas foi observado $p$ significante em duas categorias correlacionadas, nascimento de cordeiros fracos e morte neonatal ( $p=0,006$ e 0,087 ), essa correlação ocorreu pois os quatro partos de cordeiros fracos onde foi isolado campilobacter em amostras fecais, três deles vieram a óbito na primeira semana de vida. Além dessas duas categorias a retenção de placenta também apresentou valor de $p$ significante $(p=0,032)$ (Tabela 70). 
Tabela 70 - Análise de significância (valor de p) entre ovinos com isolamento de Campylobacter spp. em amostras fecais em relação à presença ou não de distúrbios reprodutivos no histórico de fêmeas ovinas - São Paulo - 2011

\begin{tabular}{|c|c|c|c|c|}
\hline Variáveis & Categoria & № de animais & Isolamentos & Valor $p$ \\
\hline \multirow[t]{2}{*}{ Aborto } & Sim & 136 & $5(3,7 \%)$ & 0,87 \\
\hline & Não & 119 & $4(3,4 \%)$ & \\
\hline \multirow[t]{2}{*}{ Endometrite } & Sim & 6 & $0(0,0 \%)$ & - \\
\hline & Não & 249 & $9(3,6 \%)$ & \\
\hline \multirow[t]{2}{*}{ Malformação fetal } & Sim & 2 & $0(0,0 \%)$ & - \\
\hline & Não & 253 & $6(2,7 \%)$ & \\
\hline \multirow[t]{2}{*}{ Morte neonatal } & Sim & 33 & $3(9,1 \%)$ & 0,087 \\
\hline & Não & 222 & $6(2,7 \%)$ & \\
\hline \multicolumn{5}{|l|}{ Nascimento de cordeiro } \\
\hline \multirow[t]{2}{*}{ fraco } & Sim & 29 & $4(13,8 \%)$ & 0,006 \\
\hline & Não & 226 & $5(2,2 \%)$ & \\
\hline \multirow[t]{2}{*}{ Natimortalidade } & Sim & 7 & $0(0,0 \%)$ & - \\
\hline & Não & 248 & $9(3,6 \%)$ & \\
\hline \multirow[t]{2}{*}{ Parto distócico } & Sim & 6 & $1(16,7 \%)$ & 0,12 \\
\hline & Não & 249 & $8(3,2 \%)$ & \\
\hline \multirow[t]{2}{*}{ Parto prematuro } & Sim & 3 & $0(0,0 \%)$ & - \\
\hline & Não & 252 & $9(3,6 \%)$ & \\
\hline \multirow[t]{2}{*}{ Prolapso uterino } & Sim & 2 & $0(0,0 \%)$ & - \\
\hline & Não & 253 & $9(3,6 \%)$ & \\
\hline \multirow{2}{*}{ Repetição de cio } & Sim & 77 & $0(0,0 \%)$ & - \\
\hline & Não & 178 & $9(5,1 \%)$ & \\
\hline \multirow[t]{2}{*}{ Retenção de placenta } & Sim & 3 & $1(33,3 \%)$ & 0,032 \\
\hline & Não & 252 & $8(3,2 \%)$ & \\
\hline
\end{tabular}

Ref.: Parâmetro de referência na análise de significância

Valores de $p \leq 0,1$ são estatisticamente significantes

Comparando os dois fatores de riscos correlacionados, a ocorrência de nascimento de cordeiros "fracos" mostrou-se com maior risco, OR=6,83, (Tabela 72) do que a morte neonatal com fator de risco de 3,5 em animais com isolamento fecal positivo para Campylobacter spp. (Tabela 71). 
Tabela 71 - Fator de risco entre ovinos com isolamento de Campylobacter spp. em amostras fecais e ocorrência de morte neonatal criatórios do estado de São Paulo - São Paulo - 2011

\begin{tabular}{lccc}
\hline Histórico reprodutivo & Valor $\mathrm{p}$ & Odds ratio & Intervalo de confiança (95\%) \\
\hline Morte neonatal & 0,087 & 3,5 & $0,83-14,72$ \\
\hline
\end{tabular}

Tabela 72 - Fator de risco entre ovinos com isolamento de Campylobacter spp. em amostras fecais e ocorrência de nascimento de cordeiro "fraco" em criatórios do estado de São Paulo - São Paulo - 2011

\begin{tabular}{lccc}
\hline Histórico reprodutivo & Valor $p$ & Odds ratio & Intervalo de confiança (95\%) \\
\hline Nasc. de cordeiro fraco & 0,006 & 6,83 & $1,73-27,05$ \\
\hline
\end{tabular}

Quanto à retenção de placenta apesar de a amostragem ser pequena $(n=3)$ e ocorrer em apenas um animal com isolamento para campilobacter, o fator de risco foi de 15,38 (Tabela 73 ).

Tabela 73 - Fator de risco entre ovinos com isolamento de Campylobacter spp. em amostras fecais e ocorrência retenção de placenta em animais de criatórios do estado de São Paulo - São Paulo - 2011

\begin{tabular}{lccc}
\hline Histórico reprodutivo & Valor $p$ & Odds ratio & Intervalo de confiança (95\%) \\
\hline Retenção de placenta & 0,032 & 15,38 & $1,26-187,61$ \\
\hline
\end{tabular}

Dentre os sinais clínicos gerais foi interessante analisar a presença de animais com diarréia e os isolamentos de campilobacter. Foi observada relação entre esse quadro com valor de $\mathrm{p}=0,003$ (Tabela 74) e fator de risco de 9,83 de ovinos positivos para campilobacter nas fezes e apresentarem diarréia (Tabela 75).

Tabela 74 - Análise de significância (valor de p) entre ovinos com isolamento de Campylobacter spp. em amostras fecais em relação a ocorrência de diarréia em animais de criatórios do estado de São Paulo - São Paulo - 2011

\begin{tabular}{lcccc}
\hline Sinal clínico & Categoria & № de animais & Isolamentos & Valor p \\
\hline Diarréia & Presença & $15(80,0 \%)$ & $3(20,0 \%)$ & 0,003 \\
& Ausência & $240(97,5 \%)$ & $6(2,5 \%)$ & \\
\hline
\end{tabular}

Valores de $p \leq 0,1$ são estatisticamente significantes

Tabela 75 - Fator de risco entre ovinos com isolamento de Campylobacter spp. em amostras fecais e ocorrência de diarréia em animais de criatórios do estado de São Paulo - São Paulo - 2011

Histórico reprodutivo $\quad$ Valor $\mathrm{p}$ Odds ratio Intervalo de confiança (95\%)

\begin{tabular}{llll}
\hline Diarréia & 0,003 & 9,83 & $2,19-44,18$
\end{tabular}


4.15 Análises de fator de risco entre as enfermidades estudadas

Foi realizado análise de fator de risco, dos parâmetros processados individualmente em cada enfermidade como já foi descrito anteriormente e agora será exposto de forma conjunta utilizando as cinco enfermidades estudadas. $O$ intuito desta comparação em conjunto foi comparar o grau de importância entre as cinco enfermidades a cada categoria ou manifestação. A seguir foram dispostas as tabelas dos parâmetros analisados onde pelo menos uma enfermidade, quando comparada com as outras, apresentou valor de $\mathrm{p}$ significante para qualquer manifestação de ordem reprodutiva ou característica dos criatórios.

Quanto à presença de estábulos nos criatórios as enfermidades que demonstraram significância foi a neosporose com $p<0,001$ e fator de risco 0,09 e a toxoplasmose, sendo que no caso da neosporose animais estabulados possuem menos risco de contrair a infecção pelo parasita, diferentemente ao que ocorreu com toxoplasmose que apresentou fator de risco de 2,25 de infecção. As outras enfermidades apresentaram $\mathrm{p}>0,1$ (Tabela 76).

Tabela 76 - Fator de risco de ovinos infectados por Brucella ovis, Campylobacter spp., Leptospiras, Neospora caninum ou Toxoplasma gondii em criatórios ovinos do estado de São Paulo que possuem estábulos - São Paulo - 2011

\begin{tabular}{lccc}
\hline & $\mathrm{n}$ & Valor $\mathrm{p}$ & Odds ratio \\
\hline Brucella ovis & $5 / 5$ & - & - \\
Campylobacter spp. & $10 / 10$ & - & - \\
Leptospirose & $58 / 67$ & 0,61 & - \\
Neospora caninum & $29 / 53$ & $<0,001$ & $0,09(0,04-0,20)$ \\
Toxoplasma gondii & $79 / 87$ & 0,08 & $2,25(0,92-5,49)$ \\
\hline
\end{tabular}

Valores de $p \leq 0,1$ são estatisticamente significantes

Em relação ao tipo de alimentação fornecida pode-se constatar que entre as cinco enfermidades, quando o criatório ovino fornece como base da alimentação pasto e concentrado o risco de infecção surge em relação à neosporose $(p=0,07$ e $\mathrm{OR}=2,45)$ e quanto à alimentação é à base de pasto, concentrado e silagem ou concentrado e silagem o risco de infecção por Toxoplasma gondii diminui com valor 
de $p$ e fator de risco de respectivamente $<0,01$ e 0,23 e 0,099 e 0,48 . As outras enfermidades não apresentaram valor de $\mathrm{p}$ significativo para nenhuma das categorias relacionas ao tipo de alimentação (Tabela 77).

Tabela 77 - Fator de risco de ovinos infectados por Brucella ovis, Campylobacter spp., Leptospiras, Neospora caninum ou Toxoplasma gondii em criatórios ovinos do estado de São Paulo de acordo com o tipo de alimentação fornecida - São Paulo - 2011

\begin{tabular}{lccc}
\hline Pastagem/Concentrado & $\mathrm{n}$ & Valor $\mathrm{p}$ & Odds ratio \\
\hline Brucella ovis & $1 / 5$ & 0,81 & - \\
Campylobacter spp. & $5 / 10$ & 0,41 & - \\
Leptospirose & $15 / 67$ & 0,60 & - \\
Neospora caninum & $23 / 53$ & 0,07 & $2,45(0,92-6,54)$ \\
Toxoplasma gondii & $37 / 87$ & 0,99 & - \\
\hline Pastagem/Concentrado/Silagem & $\mathrm{n}$ & Valor $\mathrm{p}$ & Odds ratio \\
\hline Brucella ovis & $1 / 5$ & 0,82 & - \\
Campylobacter spp. & $1 / 10$ & 0,48 & - \\
Leptospirose & $31 / 67$ & 0,17 & - \\
Neospora caninum & $22 / 53$ & 0,17 & - \\
Toxoplasma gondii & $16 / 87$ & $<0,001$ & $0,23(0,10-0,50)$ \\
\hline Concentrado/Silagem & $\mathrm{n}$ & Valor $\mathrm{p}$ & Odds ratio \\
\hline Brucella ovis & $2 / 5$ & 0,44 & - \\
Campylobacter spp. & $3 / 10$ & 0,28 & - \\
Leptospirose & $10 / 67$ & 0,97 & - \\
Neospora caninum & $2 / 53$ & 0,17 & - \\
Toxoplasma gondii & $13 / 87$ & 0,099 & $0,48(0,21-1,15)$ \\
\hline Vabres &
\end{tabular}

Valores de $p \leq 0,1$ são estatisticamente significantes

Comparando as cinco enfermidades a única que demonstrou risco de infecção em relação as outras em criatórios de sistema semi-intensivo de criação foi a neosporose com valor de $p$ de 0,001 e OR=7,88 (Tabela 78). No caso de criatórios que utilizam exclusivamente cobertura de fêmeas através da monta natural a toxoplasmose foi a que apresentou valor significante $(P=0,001)$ em relação às outras enfermidades com fator de risco de 2,37 (Tabela 79). 
Tabela 78 - Fator de risco de ovinos infectados por Brucella ovis, Campylobacter spp., Leptospiras, Neospora caninum ou Toxoplasma gondii em criatórios ovinos do estado de São Paulo em relação à utilização do sistema semi-intensivo de criação - São Paulo 2011

\begin{tabular}{lccc}
\hline $\begin{array}{l}\text { Sistema semi-intensivo } \\
\text { de criação }\end{array}$ & $\mathrm{n}$ & Valor $\mathrm{p}$ & Odds ratio \\
\hline Brucella ovis & $3 / 5$ & 0,63 & - \\
Campylobacter spp. & $7 / 10$ & 0,60 & - \\
Leptospirose & $45 / 67$ & 0,39 & - \\
Neospora caninum & $50 / 53$ & 0,001 & $7,88(2,37-26,25)$ \\
Toxoplasma gondii & $68 / 87$ & 0,18 & - \\
\hline
\end{tabular}

Valores de $p \leq 0,1$ são estatisticamente significantes

Tabela 79 - Fator de risco de ovinos infectados por Brucella ovis, Campylobacter spp., Leptospiras, Neospora caninum ou Toxoplasma gondii em criatórios ovinos do estado de São Paulo que utilizam exclusivamente cobertura de fêmeas através de monta natural São Paulo - 2011

\begin{tabular}{lccc}
\hline Monta Natural & $\mathrm{n}$ & Valor $\mathrm{p}$ & Odds ratio \\
\hline Brucella ovis & $2 / 5$ & 0,66 & - \\
Campylobacter spp. & $6 / 10$ & 0,29 & - \\
Leptospirose & $25 / 67$ & 0,13 & - \\
Neospora caninum & $22 / 53$ & 0,51 & - \\
Toxoplasma gondii & $52 / 87$ & 0,001 & $2,37(1,41-3,98)$ \\
\hline
\end{tabular}

Valores de $p \leq 0,1$ são estatisticamente significantes

$\mathrm{Na}$ análise da presença de outras espécies animais no rebanho em relação à presença de bovinos e canídeos nenhuma enfermidade se destacou em relação à outra com valor de $p$ significante. No caso da presença de felídeos entre as cinco enfermidades a leptospirose foi mais significante e com maior fator de risco ( $p=0,015$ e $O R=2,23)$. A toxoplasmose também se mostrou significante $(p=0,074)$ no entanto apresentou diminuição do risco quando a presença de felídeos nos criatórios $(\mathrm{OR}=0,62)$, enquanto as outras três enfermidades não se mostraram significantes. (Tabela 80 ). Na presença de aves nos criatórios a toxoplasmose foi à única significante com $p<0,001$ e fator de risco de 2,54 (Tabela 81) 
Tabela 80 - Fator de risco de ovinos infectados por Brucella ovis, Campylobacter spp., Leptospiras, Neospora caninum ou Toxoplasma gondii em criatórios ovinos do estado de São Paulo onde havia a presença de felídeos - São Paulo - 2011

\begin{tabular}{lccc}
\hline & $\mathrm{n}$ & Valor $\mathrm{p}$ & Odds ratio \\
\hline Brucella ovis & $3 / 5$ & 0,80 & - \\
Campylobacter spp. & $8 / 10$ & 0,29 & - \\
Leptospirose & $52 / 67$ & 0,015 & $2,23(1,17-4,23)$ \\
Neospora caninum & $32 / 53$ & 0,45 & - \\
Toxoplasma gondii & $51 / 87$ & 0,074 & $0,62(0,37-1,05)$ \\
\hline
\end{tabular}

Valores de $p \leq 0,1$ são estatisticamente significantes

Tabela 81 - Fator de risco de ovinos infectados por Brucella ovis, Campylobacter spp., Leptospiras, Neospora caninum ou Toxoplasma gondii em criatórios ovinos do estado de São Paulo onde havia a presença de aves - São Paulo - 2011

\begin{tabular}{lccc}
\hline & $\mathrm{n}$ & Valor $\mathrm{p}$ & Odds ratio \\
\hline Brucella ovis & $2 / 5$ & 0,47 & - \\
Campylobacter spp. & $5 / 10$ & 0,32 & - \\
Leptospirose & $32 / 67$ & 0,84 & - \\
Neospora caninum & $22 / 53$ & 0,76 & - \\
Toxoplasma gondii & $56 / 87$ & $<0,001$ & $2,54(1,51-4,27)$ \\
\hline
\end{tabular}

Valores de $p \leq 0,1$ são estatisticamente significantes

Entre os sinais clínicos observados durante o exame ginecológico apenas a presença de petéquias na mucosa vaginal apresentou ao menos uma enfermidade com valor de $\mathrm{p}$ significante quando comparado as outras e apresentou relação com animais com isolamento fecal de Campylobacter spp. com fator de risco de 12 (Tabela 82).

Tabela 82 - Fator de risco de ovinos infectados por Brucella ovis, Campylobacter spp., Leptospiras, Neospora caninum ou Toxoplasma gondii em criatórios ovinos do estado de São Paulo de apresentarem petéquias na mucosa vaginal - São Paulo - 2011

\begin{tabular}{lccc}
\hline & $\mathrm{n}$ & Valor $\mathrm{p}$ & Odds ratio \\
\hline Brucella ovis & $0 / 4$ & - & - \\
Campylobacter spp. & $1 / 9$ & 0,052 & $12,00(0,98-146,87)$ \\
Leptospirose & $1 / 56$ & 0,95 & - \\
Neospora caninum & $1 / 52$ & 0,98 & - \\
Toxoplasma gondii & $3 / 79$ & 0,12 & - \\
\hline
\end{tabular}

Valores de $p \leq 0,1$ são estatisticamente significantes 
Quando realizado a análise de fator de risco dos distúrbios reprodutivos entre as enfermidades estudadas, podem-se confirmar resultados observados quando esse tipo de análise estatística foi realizado individualmente.

Quanto ao aborto a toxoplasmose apresentou fator de risco de aumento da ocorrência e leptospirose e neosporose de diminuição do risco para animais sororeagentes (Tabela 83). Quadros de endometrite tiveram relação significante apenas com a leptospirose (Tabela 84). A campilobacteriose se mostrou significante em relação às outras enfermidades nos quadros de morte neonatal (Tabela 85), nascimento de cordeiros fracos (Tabela 86), distocia (Tabela 87) e retenção de placenta (Tabela 88). Por fim nos caso de repetição de cio, a neosporose apresentou maior risco que a leptospirose e a toxoplasmose apresentou queda do risco de animais reagentes repetirem cio (Tabela 89).

Tabela 83 - Fator de risco de ovinos infectados por Brucella ovis, Campylobacter spp., Leptospiras, Neospora caninum ou Toxoplasma gondii em criatórios ovinos do estado de São Paulo de apresentarem quadros de abortamentos - São Paulo - 2011

\begin{tabular}{lccc}
\hline & $\mathrm{n}$ & Valor $\mathrm{p}$ & Odds ratio \\
\hline Brucella ovis & $3 / 4$ & 0,39 & - \\
Campylobacter spp. & $5 / 9$ & 0,74 & - \\
Leptospirose & $23 / 56$ & 0,019 & $0,47(0,25-0,88)$ \\
Neospora caninum & $21 / 52$ & 0,036 & $0,51(0,27-0,96)$ \\
Toxoplasma gondii & $48 / 79$ & 0,077 & $1,65(0,95-2,88)$ \\
\hline
\end{tabular}

Valores de $p \leq 0,1$ são estatisticamente significantes

Tabela 84 - Fator de risco de ovinos infectados por Brucella ovis, Campylobacter spp., Leptospiras, Neospora caninum ou Toxoplasma gondii em criatórios ovinos do estado de São Paulo de apresentarem quadros de endometrite - São Paulo - 2011

\begin{tabular}{lccc}
\hline & $\mathrm{n}$ & Valor $\mathrm{p}$ & Odds ratio \\
\hline Brucella ovis & $0 / 4$ & - & - \\
Campylobacter spp. & $0 / 9$ & 0,99 & - \\
Leptospirose & $4 / 56$ & 0,02 & $7,50(1,31-42,82)$ \\
Neospora caninum & $0 / 52$ & 0,99 & - \\
Toxoplasma gondii & $1 / 79$ & 0,36 & - \\
\hline
\end{tabular}

Valores de $p \leq 0,1$ são estatisticamente significantes 
Tabela 85 - Fator de risco de ovinos infectados por Brucella ovis, Campylobacter spp., Leptospiras, Neospora caninum ou Toxoplasma gondii em criatórios ovinos do estado de São Paulo de apresentarem quadros de morte neonatal - São Paulo - 2011

\begin{tabular}{lccc}
\hline & $\mathrm{n}$ & $\mathrm{p}$ & Odds ratio \\
\hline Brucella ovis & $0 / 4$ & - & - \\
Campylobacter spp. & $3 / 9$ & 0,098 & $3,42(0,80-14,64)$ \\
Leptospirose & $7 / 56$ & 0,99 & - \\
Neospora caninum & $9 / 52$ & 0,41 & - \\
Toxoplasma gondii & $11 / 79$ & 0,66 & - \\
\hline
\end{tabular}

Valores de $p \leq 0,1$ são estatisticamente significantes

Tabela 86 - Fator de risco de ovinos infectados por Brucella ovis, Campylobacter spp., Leptospiras, Neospora caninum ou Toxoplasma gondii em criatórios ovinos do estado de São Paulo de apresentarem quadros de nascimento de cordeiros "fracos" - São Paulo - 2011

\begin{tabular}{lccc}
\hline & $\mathrm{n}$ & Valor $\mathrm{p}$ & Odds ratio \\
\hline Brucella ovis & $0 / 4$ & - & - \\
Campylobacter spp. & $4 / 9$ & 0,009 & $6,43(1,59-25,98)$ \\
Leptospirose & $7 / 56$ & 0,62 & - \\
Neospora caninum & $7 / 52$ & 0,83 & - \\
Toxoplasma gondii & $7 / 79$ & 0,49 & - \\
\hline
\end{tabular}

Valores de $p \leq 0,1$ são estatisticamente significantes

Tabela 87 - Fator de risco de ovinos infectados por Brucella ovis, Campylobacter spp., Leptospiras, Neospora caninum ou Toxoplasma gondii em criatórios ovinos do estado de São Paulo de apresentarem quadros de distocia - São Paulo - 2011

\begin{tabular}{lccc}
\multicolumn{4}{c}{ de apresentarem quadros de distocia - São Paulo - 2011 } \\
\hline Brucella ovis & $\mathrm{n}$ & Valor $\mathrm{p}$ & Odds ratio \\
Campylobacter spp. & $0 / 4$ & - & - \\
Leptospirose & $1 / 9$ & 0,066 & $9,95(0,86-115,10)$ \\
Neospora caninum & $2 / 56$ & 0,40 & - \\
Toxoplasma gondii & $0 / 52$ & 0,99 & - \\
\hline
\end{tabular}

Valores de $p \leq 0,1$ são estatisticamente significantes 
Tabela 88 - Fator de risco de ovinos infectados por Brucella ovis, Campylobacter spp., Leptospiras, Neospora caninum ou Toxoplasma gondii em criatórios ovinos do estado de São Paulo de apresentarem quadros de retenção de placenta - São Paulo - 2011

\begin{tabular}{lccc}
\hline \multicolumn{4}{c}{ de apresentarem quadros de retenção de placenta - São Paulo - 2011 } \\
\hline Brucella ovis & $\mathrm{n}$ & Valor $\mathrm{p}$ & Odds ratio \\
Campylobacter spp. & $0 / 4$ & - & - \\
Leptospirose & $1 / 9$ & 0,055 & $12,75(0,95-171,67)$ \\
Neospora caninum & $0 / 56$ & 0,99 & - \\
Toxoplasma gondii & $0 / 52$ & 0,99 & - \\
\hline
\end{tabular}

Valores de $p \leq 0,1$ são estatisticamente significantes

Tabela 89 - Fator de risco de ovinos infectados por Brucella ovis, Campylobacter spp., Leptospiras, Neospora caninum ou Toxoplasma gondii em criatórios ovinos do estado de São Paulo de apresentarem quadros de repetição de cio - São Paulo - 2011

\begin{tabular}{lccc}
\hline & $\mathrm{n}$ & Valor $\mathrm{p}$ & Odds ratio \\
\hline Brucella ovis & $1 / 4$ & 0,88 & - \\
Campylobacter spp. & $0 / 9$ & - & - \\
Leptospirose & $21 / 56$ & 0,084 & $1,78(0,93-3,41)$ \\
Neospora caninum & $16 / 52$ & 0,038 & $2,02(1,04-3,92)$ \\
Toxoplasma gondii & $21 / 79$ & 0,013 & $0,44(0,23-0,84)$ \\
\hline
\end{tabular}

Valores de $p \leq 0,1$ são estatisticamente significantes

\section{DISCUSSÃO}

A discussão dessa tese foi subdividida em tópicos de acordo com as enfermidades estudadas

5.1 Brucelose e Actinobacillus seminis

A freqüência de Brucella ovis observada nos rebanhos paulistas foi baixa em relação a outros trabalhos nacionais (AZEVEDO et al., 2004c; NOZAKI et al., 2004; CLEMENTINO et al., 2007) ocorrendo resultado semelhante apenas com Ueno 
(2010) que realizou estudo na região oeste do mesmo estado. Essa diferença pode ter ocorrido, pois no presente trabalho o número de machos utilizados foi bem menor que o de fêmeas $(12,6 \% \times 87,4 \%)$ sendo que elas apresentaram na pesquisa maior número de indivíduos com alterações reprodutivas. Quando a análise foi realizada com os dois sexos obteve-se freqüência $(1,7 \%)$. Como a Brucella ovis é mais observada causando quadro clínico em machos, responsável pela Epididimite Contagiosa dos Ovinos (NAREZ et al., 1999) ao realizar-se a freqüência só dos machos, o resultado ainda permaneceu baixo $(2,7 \%)$ neste estudo. A razão deste resultado pode ser devido à parte das cabanhas estudadas serem tecnificadas, com algumas trabalhando exclusivamente com a venda de matrizes e reprodutores, por isso provavelmente são mais atentos a casos de orquite, epididimite ou infertilidade dos animais, sendo os problemáticos eliminados do rebanho. Clementino et al. (2007) na Paraíba, estudando somente machos criados em sistema extensivo, obtiveram $5,57 \%$ (28/498) de animais positivos.

A baixa freqüência no estado de São Paulo é semelhante a trabalhos realizados em países como Espanha (REVIRIEGO; MORENO; DOMÍNGUEZ, 2000), Canadá (ARSENAULT et al., 2004) Cazaquistão (LUNDERVOLD et al., 2004) e Austrália (SAUNDERS et al., 2007), sendo que em países subdesenvolvidos como México (NAREZ et al., 1999) e Jordânia (Al-MAJALI et al., 2007) encontra-se freqüências maiores assim como em outras regiões do Brasil (AZEVEDO et al., 2004c; CLEMENTINO et al., 2007).

Essa diferença regional também é observada nos trabalhos internacionais ou ainda no mesmo rebanho quando realizados controles anuais, como o ocorrido na Argentina onde Epstein et al. (1964) encontraram 15,3\% de carneiros com epididimite e Alonso et al. (2007) na região de Pampa de Achala, Córdoba, não encontraram ovinos positivos em 1.507 amostras. Robles et al. (1998) no mesmo rebanho em três anos obtiveram 2,1\%,4\%,6,3\% e em trabalhos Iranianos em cinco estudos distintos as freqüências variaram entre 1 e 7,1\% (SHAREEF, 2006). A incidência de Brucella ovis pode variar também quando estudadas diferentes raças ovinas, como por exemplo, no Reino Unido onde nas raças Merino, Border Leicester e Dorset a freqüência foi de $5 \%, 19 \%$ e $26 \%$ respectivamente (SERGEANT, 1994) e na África do Sul onde reprodutores a raça Dorper foram mais acometidos que da raça Merino (WET; ERASMUS, 1984). No presente trabalho as amostras reagentes 
foram provenientes de quatro cabanhas sendo três fêmeas da raça Santa Inês, uma da raça Sulfok e um macho da raça Texel, não pode é possível afirmar se houve maior ocorrência entre as raças, pois a maioria dos animais colhidos neste estudo foi da raça Santa Inês $(53,4 \%)$.

Nesse estudo não foi realizada pesquisa sorológica para Brucella melitenses, pois no Brasil não há antígeno para realização da mesma e o país é considerado livre dessa espécie (POESTER; GONÇALVES; LAGE, 2002). No entanto são necessárias ações preventivas para que a mesma não penetre nos rebanhos brasileiros. Brucella melitensis ocorre em rebanhos de países vizinhos como Peru e Argentina, além do risco de importação de animais de países da região Mediterrânea, Ásia Central, Extremo Oriente, África e alguns países da América Central, do Norte e Europa (BENKIRANE, 2006). Resultados de programas de erradicação de Brucella melitenses em países europeus mostraram freqüências que variaram de $0,16 \%$ a 19,49\% (GODFROID; KÄSBOHRER, 2002).

Nesta pesquisa não foi realizada o diagnóstico de Brucella abortus, no entanto há relatos que a presença da mesma ocorra em rebanhos ovinos em uma porcentagem baixa. Pinheiro Junior et al. (2008) relataram em Pernambuco, 2,5\% de ovinos sorreagenes em 360 amostras. Nozaki et al. (2004) pesquisaram em São Paulo e não encontraram animais reagentes. Neste estudo, dos 294 animais pertencentes nesta pesquisa, apenas $20 \%$ pertenciam a propriedades onde havia criação de bovinos consorciado, que é um dos fatores predisponentes para a presença da bactéria nos ovinos (OCHOLI et al., 2005; PINHEIRO JUNIOR et al., 2008).

Apesar da pequena quantidade de fêmeas sororeagentes, as mesmas podem servir como reservatório da bactéria contaminando carneiros no momento do coito (BROWN; PIETZ; PRIC, 1973), além de eliminar a bactéria no ambiente através dos produtos do abortamento (BUDDLE, 1956). No caso das quatro fêmeas do trabalho isso pode se intensificar, pois todos os animais pertencem a propriedades onde há presença de estábulo e sistema de criação intensivo ou semi-intensivo, essas características demonstram um maior contato entre os animais e também com fetos, secundinas e secreções uterinas que podem carrear a bactéria. Apesar de não ter sido possível relacionar estatisticamente a presença de Brucella ovis com os problemas reprodutivos observados nos animais do estudo, três das quatro fêmeas 
positivas apresentaram em seu histórico reprodutivo quadro de abortamento, podendo servir como foco de disseminação da bactéria no rebanho, no entanto não podemos afirmar que o fato se deu devido à presença da bactéria, pois não foi possível a colheita do feto abortado para realização de isolamento bacteriano e dois animais eram reagentes a Toxoplasma gondii e um a Leptospira sejroe sorovar hardjobovis (100) concomitantemente. A outra fêmea apresentava queixa de repetição de cio e também era positiva Leptospira autumnalis sorovar autumnalis (200).

Outra situação a se observar é que duas fêmeas positivas pertenciam a cabanha que realizavam colheita e transferência de embriões além da monta natural. Sabe-se da capacidade da Brucella ovis aderir a zona pelúcida se não for realizado adequada manipulação desses embriões no momento da lavagem com antibióticos essa biotecnologia pode disseminar vastamente a bactéria até mesmo entre fronteiras (WOLFE et al., 1988).

Dos 37 machos que foram submetidos ao diagnóstico de Brucella ovis, foi encontrado apenas um animal sororeagente, que não apresentava sinais clínicos palpáveis no testículo e epidídimo e circunferência testicular de $32 \mathrm{~cm}$, dentro dos parâmetros normais para a raça (Figuras 16) (OLIVEIRA et al., 2010). Mesmo em animais sororeagentes é descrito que apenas 30 a $40 \%$ destes irão manifestar sinais palpáveis em alguma região do epidídimo (Epididimite contagiosa ovina) (HUGHES; CLAXTON, 1968). Em animais experimentalmente infectados, também não serão todos que irão manifestar lesões detectáveis à palpação no trato reprodutivo (PAOLICCHI et al., 2000). Quispe, Rivera e Rosadio (2002) relataram que o meio mais seguro para detectar se há a presença da bactéria no rebanho é o exame sorológico, pois parte dos carneiros não manifestam sinais clínicos (HUGHES; CLAXTON, 1968; ROBLES et al., 1998; PAOLICCHI et al., 2000) e podem carrear e eliminar a bactéria muito tempo antes de apresentar lesões palpáveis no aparelho reprodutor (KOTT et al. 1988).

O reprodutor soropositivo do estudo era um portador assintomático e possível disseminador da infecção no rebanho, pois não foram observadas lesões palpáveis ou macroscópicas no momento da necropsia (Figuras 17). A disseminação ocorre principalmente durante a estação de monta onde trabalhos relatam aumento de animais positivos no final da estação em relação aos observados no início (QUISPE; 
RIVERA; ROSADIO, 2002), no entanto não foi encontrado mais nenhum ovino positivo entre as outras 41 amostras colhidas na mesma propriedade sendo 15 machos e 26 fêmeas. O quadro assintomático foi confirmado, pois não foi possível o isolamento da bactéria em amostras seminais do ejaculado ou de punção epididimária, sendo que grande parte dos animais com sorologia positiva não excretam a bactéria no sêmen (FICAPAL et al., 1998), como observado por Narez et al. (1999) que obtiveram isolamento em apenas 2 de 17 carneiros e no exame macroscópico do trato reprodutivo após necropsia não foi observado presença de nódulos nos epidídimos e/ou alterações testiculares como relatada por outros autores de extravasamento de exudato fibrinoso na região da túnica vaginal, amarelado de consistência cremosa (BUDDLE, 1956; EPSTEIN et al., 1964; CAMERON; LAUERMAN JUNIOR, 1976; BURGESS; McDONALD; NORRIS, 1982; ROBLES, 1998; PAOLICCHI et al., 2000; NAREZ et al., 1999). O crescimento bacteriano também não foi possível nos órgãos colhidos, epidídimo direito e esquerdo, pênis, próstata, bexiga, fígado, rins, baço e bile, como na maioria dos animais estudados por Blobel et al. (1972) que obtiveram isolamento em apenas 8 epidídimos de 24 carneiros com epididimite e sêmen necrospérmico ou azoospérmico contendo leucócitos e bactérias semelhantes à Brucellas.

O diagnóstico sorológico, que foi confirmado com repetição do exame após seis meses da primeira colheita e a impossibilidade do diagnóstico clínico ou bacteriológico é explicado com o trabalho de Ficapal et al. (1998) que estudaram a relação entre as três possibilidades diagnósticas em 110 ovinos e observaram; $50,9 \%$ de animais sororeagentes, 30,9\% de sororeagetes e com lesões testiculares macroscópicas, 20,9\% sorologicamente negativo e com lesões testiculares macroscópicas e $23,6 \%$ de isolamentos bacterianos.

Apesar de ser o principal agente da Epididimite Contagiosa dos Ovinos, entre os outros 36 machos submetidos ao diagnóstico sorológico e em 16 ao bacteriano, haviam animais com sinais clínicos de orquite, epididimite, hipoplasia testicular, baixa fertilidade e que não foram positivos a Brucella ovis, isso demonstra que outros agentes etiológicos podem estar agindo nos reprodutores ovinos no Brasil, sendo necessário atenção para realizar-se o diagnóstico diferencial como realizado neste trabalho onde se isolou Actinobacillus seminis de ovino com quadro de orquite. Mas outros fatores e agentes merecem atenção no caso de aumento de volume 
escrotal como hidrocele, hematocele, varicocele, neoplasias hérnias inguinais, inflamação dos envoltórios, criptorquidismo, espermatocele (PASTOR, 2006) que não foram observados nesse trabalho, pois algumas dessas alterações seriam perceptíveis à palpação do trato reprodutivo.

Dentre as diferentes etiologias de problemas reprodutivos em machos ovinos encontradas nesse estudo podemos citar a presença de dermatite e ectoparasitos que a longo prazo poderiam comprometer a qualidade espermática devido aumento da temperatura testicular referente a processo inflamatório local. Histophilus somnus (SAUNDERS et al., 2007) foi pesquisado nas amostras de sêmen e não ocorreu nenhum crescimento bacteriano. Streptococcus, Staphylococccus, Escherichia coli, foram isolados em 15, 1 e 8 amostras seminais respectivamente. Em amostras colhidas pelo método de zaragatoa prepucial quando não era possível colher a amostra seminal encontrou-se dois animais com Streptococcus, dois com Staphylococcus e um com Escherichia coli. Foi isolado também em zaragatoa prepucial Corynebacterium spp, Pseudomonas, Pasteurellas, Arcanobacterium pyogenes, Escherichia coli e Chlamydofila abortus, nestes casos considerou-se estes isolados como contaminação secundária no momento da colheita. Vírus, que não foram pesquisados nesse estudo, também podem agir no trato reprodutivo de carneiros como o da Maedi-Visna, Varíola Ovina e Border Diseases (PALFI; GLAVITIS; HAJTÓS, 1989).

Nas fêmeas positivas para brucelose não foram colhidas nenhuma amostra para realização de isolamento bacteriano, pois no momento da colheita as mesmas não apresentavam secreções uterinas ou secundinas. Foram colhidas 16 outras amostras de fêmeas com histórico de problema reprodutivo e que no momento do exame clínico apresentavam secreções. Os materiais colhidos e examinados foram útero de uma fêmea que foi abatida no momento da colheita, secundinas, secreções uterinas e zaragatoa vaginal e também, 16 fetos abortados. Em nenhuma delas ocorreu crescimento bacteriano de Brucellas, mesmo com a dificuldade de se isolar o agente principal, o resultado confirmou os exames sorológicos destes animais, pois não eram sororeagentes para Brucella ovis.

Neste trabalho foi possível o isolamento de Actinobacillus seminis em amostra seminal de ovino da raça Dorper sendo o terceiro relato realizado no Brasil e primeiro no estado de São Paulo (GREGORY et al., 2009), outros relatos devem ser 
realizados para que se difunda mais a existência e a importância dessa bactéria nos reprodutores ovinos, pois é diagnóstico diferencial da brucelose ovina, causando alterações clínicas semelhantes, no entanto trabalhos mostram maior ocorrência em machos de faixa etária diferente do animal do estudo (WET; ERASMUS, 1984; GOMES et al., 2001). A bactéria cada vez mais ganha importância na ovinocultura sendo isolada desde 1960 em diversos países tais como Austrália, Nova Zelândia, Estados Unidos, México, Argentina, Espanha, Hungria, Reino Unido, África do Sul e Kenya (BAYNES; SIMMONS, 1960; LIVINGSTON JUNIOR; HARDY, 1964; WORTHINGTON; BOSMAN, 1968; GUMBRELL; SMITH, 1974; BRUERE et al., 1977; ERASMUS; WET; PROZESKY, 1982; SWIFT et al., 1982; SPONENBERG et al., 1983; HAJTÓS, 1987; HAJTÓS et al., 1987; ROBLES et al., 1990; HEATH et al., 1991; LOW et al., 1995; MBAl et al., 1996; NAREZ et al., 1999; PUENTE-REDONDO et al., 2000).

O animal onde ocorreu o isolamento da bactéria possuía 3 anos e meio, discordando de alguns autores que afirmam que a mesma acomete machos quando atingem a maturidade sexual (BAGLEY; HEALEY, 1997; BULGIN; ANDERSON, 1983; WALKER; LEAMASTER, 1986; BULGIN, 1990), no entanto por ser uma condição irreversível (SIMMONS; BAYNES; LUDFORD, 1966; WET; ERASMUS, 1984) o animal pode apresentar sinais clínicos em idade posterior, quando o trato genital é mais exigido, por exemplo, quando colocado em estação de monta como ocorreu com o animal do estudo que apresentou sinais de orquite durante estação de monta, foi colocado em repouso sexual e tratado com antibioticoterapia e quando recolocado com trinta fêmeas voltou a manifestar o quadro. Outros trabalhos também relatam o aparecimento da infecções testiculares em situações de estresse para o macho, como final da estação de monta que ocorreu aumento das manifestações clínicas dos animais infectados por Brucella ovis (QUISPE; RIVERA; ROSADIO, 2002). O animal positivo no isolamento bacteriano do estudo era um reprodutor de alto valor zootécinico como observado no estudo de Saunders et al. (2007), que geralmente são precoces sexualmente (JANSEN, 1983) ocorrendo mudanças hormonais e na flora prepucial mais bruscas, tornando-os segundo Jansen (1980) mais expostos à infecção descendente no trato reprodutivo de ovinos (AL-KATIB; DENNIS, 2008b). A orquite observada foi unilateral, acometendo somente o testículo direito (SWIFT et al., 1982) mantendo a função do testículo 
esquerdo, pois mesmo com a infecção, ao ser realizado o exame ultrassonográfico das trinta fêmeas colocadas para a cobertura, obteve-se $66,7 \%$ de taxa de gestação.

No momento do exame clínico e colheita de sêmen a circunferência escrotal estava aumentada $(43 \mathrm{~cm}$ ), para a idade e raça (FOURIE et al., 2005), devido à orquite no testículo direito caracterizada por dimensões aumentadas, consistência firme, pouca mobilidade na bolsa, ausência de sensibilidade, presença de edema e epidídimo aumentado em suas três regiões, sinais da fase aguda da infecção (ALKATIB; DENNIS, 2005, 2007). O aumento de volume escrotal dificultava a monta, pois ao movimento os testículos se chocavam aos jarretes lesando a região podendo segundo Bulgin, Bruss e Anderson (1990) agravar o quadro com a formação de granulomas espermáticos mediados por condições auto-imunes sem presença de bactérias devido a traumas no epididimo causando extravasamento de fluídos ricos em proteínas.

A descrição e localização de lesões epididimais com mais detalhes como presença de granulomas, região mais afetada não foram possivéis pois não foi realizado exame necroscópico para melhor detalhamento e somente com a palpação da regíão o que se pode descrever foi: hiperplasia uniforme de todo o órgão, contrariando autores que relatam a cauda do epidídimo como a região mais afetada (MBAI et al., 1996; PUENTE-REDONDO et al., 2000; AL-KATIB; DENNIS, 2008b).

Não foram observados sinais clínicos sistêmicos relacionados à infecção do trato reprodutivo (AL-KATIB; DENNIS, 2005) tão pouco postite severa (WATT; BAMFORD; NAIRN, 1970) as alterações se limitavam ao testículo e epidídimo direito, somente foi notado mucosa hipocorada devido à infestação parasitária detectado pelo OPG, sendo também um sinal de susceptibilidade do animal a infecções e/ou manifestações de sinais clínicos de bactérias oportunistas como o Actinobacillus seminis, pois o animal se encontrava parasitado e em fase de esforço físico devido estação de monta.

A colheita de sêmen foi realizada pelo método de vagina artificial e apesar de o reprodutor apresentar boa libido, durante os primeiros saltos o mesmo não ejaculou, talvez por alguma obstrução devido o aumento de volume da região comprimindo algum ducto ou ainda devido à sensibilidade do local. Após algumas tentativas obteve-se uma amostra de $0,6 \mathrm{ml}$ de ejaculado de aspecto aquoso e azospérmico, característico de líquido pré-seminal secretado pelas glândulas anexas 
que Dibarrat et al. (2006), sugeriram ser reservatório da bactéria e de onde foi possível realizar o isolamento. Já Simmons, Baynes e Ludford (1966) isolaram a bactéria em glândulas vesiculares, bulbo uretral, corpo do epididimo e sêmen nos dando a hipótese de a bactéria, no caso do ovino do trabalho, estar instalada no epididmo que encontrava-se todo comprometido.

Não foi possível analisar parâmetros do exame andrológico tais como observados por outros autores em animais infectados (BAYNES; SIMMONS, 1968; LOW et al., 1995; MBAl et al., 1996; GOMES et al., 2001), pois o ejaculado estava azospérmico. No entanto isso nos leva a sugerir que o grau de lesão era alto no momento da colheita levando o animal a infertilidade mesmo com o testículo esquerdo não apresentando lesões palpáveis.

Não é possivel afirmar se ocorreu infecção descendente ou ascendente no trato reprodutivo (AL-KATIB; DENNIS, 2008b) ou venéria, que segundo autores não é uma via importante de transmissão (SIMMONS; BAYNES; LUDFORD, 1966; SWIFT et al., 1982; WALKER; LEAMASTER, 1986; MBAl et al., 1996; PUENTEREDONDO et al., 2000). Uma das hipóteses pode ser devido a características do reprodutor como a precocidade reprodutiva, alto valor zootécnico (JANSEN 1983), susceptibilidade da raça que Wet e Erasmus (1984) observaram que a raça Dorper apresentou mais isolados e sinais clínicos quando comparada a raça Merino podendo a raça apresentar susceptibilidade a infecção ou ainda graças à maior exigência do trato reprodutivo na estação de monta que tenha desencadeado algum mecanismo de proliferação da bactéria e subseqüente manifestação clínica. A transmissão pela monta natural, não pode ser descartada, mesmo não havendo quadros de abortamentos no rebanho como relatados por Hajtós (1987) e Foster et al. (1999), pois mesmo não sendo associada a casos de abortos em ovinos a mesma pode ser encontrada na microbiota vaginal principalmente de fêmeas jovens (WALKER; LEAMASTER, 1986) servindo de reservatório da bactéria e propagação no rebanho aonde os sinais clínicos irão se manifestar nos reprodutores e raramente nas fêmeas, no entanto não foram realizadas colheitas de secreção vaginal e não se sabe a idade das fêmeas que o reprodutor cobriu.

Não houve isolamento em outras amostras seminais de machos com ou sem sinais clínicos. Quanto às amostras de fêmeas e abortamentos submetidas ao isolamento, não ocorreu crescimento de Actinobacillus seminis assim como 
Simmons, Baynes e Ludford (1966) que não obtiveram sucesso no isolamento em amostras de leite, muco vaginal, cotilédones útero e orgãos de natimortos de fêmeas soropositivas.

O tratamento antimicrobiano com utilização de enrofloxacina $5 \%$ e florfenicol não foi eficaz, assim como relatado com outros princípios ativos (ERASMUS; WET; PROZESKY, 1982; HEATH et al., 1991) sendo recomendado o descarte do animal ou ainda orquiectomia do testículo afetado no caso de animais de alto valor zootécnico e financeiro. A vacinação preventiva contra Brucella ovis não se mostrou eficaz para prevenção de outros agentes causadores de alterações no trato reprodutivo de ovinos (SWIFT et al., 1982)

\subsection{Leptospirose}

No estudo $22,8 \%$ dos ovinos apresentaram reação de soroaglutinação positiva para leptospiras, essa freqüência foi à mesma observada por Viegas, Viegas e Caldas (1980) no estado da Bahia e próxima a observada por Caldas et al. (1983) no mesmo estado $(23,8 \%)$. Comparado com os inquéritos realizados no estado de São Paulo, esse estudo apresentou freqüências menores (SANTA ROSA; CASTRO, 1963; SANTA ROSA et al., 1969/1970; LANGONI et al., 1995) assim como o realizado no Rio Grande do Sul (HERMANN et al., 2004). Lilenbaum et al. (2009) no Rio de Janeiro foram os que observaram menor freqüência entre os inquéritos listado com $13,7 \%$ de animais positivos.

O sorovar mais freqüente foi o autumnalis presente em 33 amostras, assim como ocorreu com Viegas, Viegas e Caldas (1980) e Caldas et al. (1983) na Bahia. Este resultado nos induz a pensar de que a contaminação dos rebanhos ovinos em grande parte se deve a presença de animais silvestres nas regiões de criação, e estes foram mais importantes como fonte de infecção do que os criatórios consorciados com bovinos.

O segundo foi o icterohaemorrhagiae em 11 amostras, esse sorovar foi o mais observado por Langoni et al. (1995) em São Paulo. Nota-se que trabalhos mais antigos os serovars mais prevalentes diferem dos sorovares de estudos mais 
recentes e isto se deve a diferenças no tipo de criação nos diferentes períodos pois na época que Langoni fez os estudos não haviam muitas criações de ovinos de corte no estado de São Paulo, a maioria dos ovinos eram lanados e geralmente havia cães na lida destes animais.

O sorovar hardjo é o mais freqüente em todo o mundo e está presente em várias espécies, e maior causador de problemas reprodutivos em ovelhas e morte de cordeiros, sendo isolado em casos de abortamentos (HATHAWAY; MARSHALL, 1979; BAHAMAN et al., 1980; SCHMITZ; COLES; SHIRES, 1981; BLACKMORE; BAHAMAN; MARSHALL, 1982; ELLIS et al., 1983; KRAWCZYK, 2005; LILENBAUM et al., 2009). Nesse estudo foram encontrados 9 ovinos sororeagentes a Sejroe sorovar hardjo (hardjoprajitno) e 7 sororeagentes a Sejroe sorovar hardjobovis concordando com os autores acima. Deve-se levar em conta a criação consorciada com bovinos e por esta razão a presença deste sorovar predominante nesta espécie. Há relatos também de que os ovinos são reservatórios deste sorovar ou de leptospirose e transmitem para os bovinos, pois a espécie é mais susceptível que a ovina.

São descritos outros sorovares associados a problemas reprodutivos, porém com menor freqüência, destacando-se os sorovares Pomona, Ballum, Bratislava e Grippotyphosa (BLACKMORE; BAHAMAN; MARSHALL, 1982; ELLIS et al., 1983). Evidências clínicas de leptospiras em ovinos são associadas à infecção pelos sorovares: Pomona (HARTLEY, 1952; SULLIVAN, 1974; DAVISON; HIRSCH, 1980; LEON-VIZCAINO; HERDOSO DE MENDOZA; GARRIDO, 1987) Griootyphosa (LEON-VIZCAINO; HERDOSO DE MENDOZA; GARRIDO, 1987; OZDEMIR; EROL, 2002), Ballum, Icterohaemorrhagie e Sejroe (LEON-VIZCAINO; HERDOSO DE MENDOZA; GARRIDO, 1987) e Hardjo (ELLIS et al., 1983; McKEOWN; ELLIS, 1986). Podem ser observados diferentes sorovares de leptospiras no mesmo ovino (BLACKMORE; BAHAMAN; MARSHALL, 1982; HAJI HAJIKOLAEI, 2007) como observado neste estudo.

A primeira investigação no Brasil em ovinos foi realizada por Santa Rosa e Castro no ano de 1963 no estado de São Paulo constatando 34\% (136/400) de animais reativos, os sorovares observados dispostos de forma decrescente foram: canicola, pomona, icterohaemorrhagiae, serjoe, grippotyphosa, hyos e bataviae com títulos que variaram de 1:200 a 1:1600, posteriormente Santa Rosa et al. 
(1969/1970) em estudo retrospectivo encontraram 29,7\% de ovinos positivos, repetindo a ordem dos quatro sorovares principais observados no estudo anterior.

Viegas, Viegas e Caldas (1980) obtiveram 22,8\% no estado da Bahia, com predomínio dos sorovares autumanlis e castelloni. Também na Bahia, Caldas et al. (1983), obtiveram de 1.130 amostras de soros ovinos, 23,8\% de reações positivas para o sorovar autumnalis, 20,1\% castellonis e 11,2\% pomona.

No estado de São Paulo Langoni et al. (1995) encontraram pela prova de macroaglutinação em placa $41,92 \%$ e por aglutinação macroscópica $44,94 \%$ de positivos. Dentre os sorovares estavam icterohaemorrhagie $(51,25 \%)$, castellonis $(20,63 \%)$, hardjo $(19,38 \%)$, bratislava (16,25\%) andamana e wolffi $(11,88 \%)$, copenhageni (8,75\%), grippothyphosa (4,38\%), pomona $(2,5 \%)$ e tarassovi $(0,63 \%)$. Favero et al. (2002) no mesmo estado encontraram apenas 0,7\% (2/284) de animais reatores.

No Rio Grande do Sul, Hermann et al. (2004) dentre 1.360 ovinos observaram $34,26 \%$ de positivos, com animais reativos para os seguintes sorovares: 210 hardjo, 152 sentot, 133 hardjoprajitno, 73 fortbragg, 39 wolffi, 25 pyrogenes, 21 australis, 20 pomona, 19 serjoe, 18 castellonis, 17 hebdomadis, 16 icterohaemorrhagiae, 9 grippotyphosa, 8 canicola, 7 tarassovi, 4 bratislava e 3 autumnalis.

Dos sorovares citados dos estudos nacionais pesquisando ovinos, nessa pesquisa não foi observado reação com os sorovares: andamana, bataviae, canicola, fortbragg, hebdomadis, hyos, pyrogenes e tarassovi.

Dentre os parâmetros analisados dos criatórios a única categoria onde ocorreu valor de $p$ significante foi a presença de felinos nas propriedades $(P=0,018)$ com fator de risco de 2,15 (Tabela 36). Durante as colheitas foi questionado aos tratadores qual a utilidade dos felinos nos criatórios e esses justificaram que era para o combate de roedores, este motivo foi citado por todos os tratadores. Os tratadores foram orientados a evitar este procedimento, conscientizando-os que o combate aos roedores deve visar à higiene das instalações, armazenamento dos alimentos e destino correto dos detritos, pois somente a presença de felinos não irá combater o problema e poderá acarretar a presença da toxoplasmose no rebanho uma vez que eles são os principais transmissores (FRENKEL; RUIZ; CHINCHILLA, 1975).

A leptospirose se mostrou significante em casos de abortamento, no entanto a análise de fator de risco mostrou queda do risco em animais sororeagentes. Os 
fatores que podem levar a esse resultado e a não ocorrência de relação com distúrbios reprodutivos seria de que os sinais clínicos diferirem de acordo com sorotipo, virulência, carga de inóculo, susceptibilidade, condição física e idade do animal (SMITH; REYNOLDS; SATAKI, 1960a; SMITH; REYNOLDS; CLARK, 1962; FAINE, 1982) e devido à baixa titulação encontrada nos animais do estudo, essas podem ser ocasionadas por leptospiras de baixa virulência. Além disso, os ovinos apresentam menor susceptibilidade à infecção (LEON-VIZCAINO; HERDOSO DE MENDOZA; GARRIDO, 1987; CICERONI et al., 2000).

Hathaway, Wilesmith e Little (1984) demonstraram que quanto maior a densidade de bovinos em uma propriedade, maior será a prevalência de ovinos infectados por Leptospira interrogans sorovar hardjo, pois os mesmos agem mantendo e eliminando esse sorovar no rebanho em nosso estudo não foi notada relação entre criatórios onde havia presença de bovinos como maior risco de animais sororeagentes.

\subsection{Neospora caninum}

Os resultados de levantamentos sorológicos para Neospora caninum em ovinos em rebanhos brasileiros começaram em 2004 (FIGLIUOLO et al., 2004), pois na ovinocultura a presença do parasita só foi relatada há duas décadas (DUBEY et al., 1990). Em nossos rebanhos as freqüências observadas nos estudos variaram entre 1,8\% e 10,5\% mesmo sendo realizados em regiões distintas do país (FIGLIUOLO et al., 2004; OTERO et al., 2005; VOGEL; ARENHART; BAUERMANN, 2006; ROMANELLI et al., 2007; UENO et al., 2009; SOUZA NETO et al., 2009; SOARES et al., 2009; FARIAS et al., 2009) com exceção os de Aguiar et al. (2005), Rossi et al. (2008) que relataram no município de Monte Negro-RO e Uberlândia$M G$, freqüência de $29 \%$ e $47 \%$ respectivamente. Em nosso estudo a freqüência observada não é comparada a nenhum dos relatos nacionais com $18 \%$ de animais sororeativo sendo apenas um macho positivo dentre essas amostras. Isso pode ter ocorrido, pois grande parte dos trabalhos realizaram apenas a freqüência nos rebanhos, sem utilização exclusivamente de animais com problemas reprodutivos 
como o ocorrido nesse estudo e com isso possa ter ocorrido um aumento da freqüência em relação à média dos trabalhos em rebanhos nacionais em diferentes estados.

Nos relatos internacionais também não foi observada freqüências semelhantes mesmo quando o estudo utilizou rebanhos com histórico de problemas reprodutivos como no Reino Unido, Eslováquia e Suíça com freqüências de 0,45\%, 3,7\% e 10,3\% respectivamente (HELMICK et al., 2002; HÄSSIG et al., 2003; ŚPILOVSKÁ et al., 2009) nos estudos onde foram utilizados animais saudáveis a freqüência não se alterou variando entre 2\% a 12\% (GAFFURI et al., 2006; ALMAJALI et al., 2008; BÁRTOVÁ; SEDLÁ; LITERÁ, 2009; PANDERO et al., 2010)

Análise de fator de risco demonstrou que fêmeas ovinas possuem 9,13 vezes mais chances de se infectar que os carneiros, essa associação não ocorreu em outros estudos nacionais (GARCIA et al., 1999; FIGLIUOLO et al., 2004; ROMANELLI et al., 2007; UENO et al., 2009). Nesse estudo apenas um macho foi soropositivo para Neospora caninum, uma das possibilidades seria devido na maior parte dos criatórios os mesmos possuem baias individuais ou com pouca lotação, expondo-os menos ao ambiente e outros ovinos.

Foi observado também que em criatórios que não possuem estábulos, onde os animais permanecem a maior parte do tempo a campo, o fator de risco em relação a propriedades que possuem estábulos foi 9,58 maior $(p<0,001)$ e o sistema semi-intensivo em relação ao intensivo apresentou fator de risco 7,86 maior $(p=0,001)$.

Com esses dados nota-se que uma maior exposição ao ambiente pode acarretar em aumento da incidência da infecção pelo parasita que pode permanecer viável por mais tempo em regiões úmidas (CORBELLINI et al., 2006), discordando com outros estudos que apresentam a via transplacentária como principal via de contágio (McALLISTER et al., 1998; FIGLIUOLO et al., 2004; ROMANELLI et al., 2007). No entanto assim como outros autores (FIGLIUOLO et al., 2004; ROMANELLI et al., 2007; SOARES et al., 2009; SOUZA NETO et al., 2009) não foi observado relação entre a presença de canídeos e a infecção por Neospora caninum, discordando com os resultados de Corbellini et al. (2006) quando estudou o parasita em rebanhos bovinos. 
Em geral criatórios de sistema semi-intensivo e/ou sem estábulo possuem manejo sanitário menos eficiente que em sistemas intensivo com a presença de estábulos por isso podem ocorrer falhas que aumentem o fator de risco da enfermidade como com pastagens em comuns de diferentes rebanhos $\mathrm{e}$ fornecimento de diversos tipos de fonte de água (AL-MAJALI et al., 2008; FARIAS et al., 2009).

$\mathrm{Na}$ análise do tipo de alimento fornecido, a única categoria que apresentou risco em relação ao fornecimento de pastagem foi a alimentação de pastagem e concentrado que aumentou em 2,58 o risco de infecção. Pode supor que a presença de ovinos se alimentando a pasto e expostos a oocistos levem a esse resultado pois quando foi introduzida a silagem na alimentação, diminuindo o consumo de pastagem, ou ainda o não fornecimento de pasto aos ovinos os valores de $p$ não mostraram significância (Tabela 46). Esses fatores, sistema semi-intensivo, ausência de estabulação e influência do consumo de pastagem levam a crer que o principal meio de transmissão foi a oral, além do resultado obtido em relação ao grupo de ovinos de raças lanadas que apresentaram fator de risco de 1,73 em relação às outras raças, pois apesar de não ter ocorrido correlação com a presença de canídeos com o aumento de ovinos reagentes a Neospora caninum, em todos os criatórios de ovinos lanados que participaram do estudo possuíam cães em contato com os ovinos e $69,8 \%$ das amostras reagentes ao parasitas foram oriundas de criatórios que possuíam cães. Essa hipótese contraria a afirmação de McAllister et al. (1998) que relata que o principal meio de transmissão é a transplacentária.

A infecção por Neospora caninum demonstrou na análise de fator de risco, diminuição do risco de casos de abortamentos nos animais sororeagentes. Concordando com autores que relatam raros os casos de abortamento ovino causados por Neospora caninum, principalmente pela baixa incidência de isolamento ou deteç̧ão em estudo com fetos abortados (OTTER et al., 1997; BUXTON; McALLISTER; DUBEY, 2002; HELMICK et at., 2002; MASALA et al., 2007). Há relatos que esclarecem o fato de raros abortamentos em ovinos pois Buxton et al. (2001) relata que ovelhas infectadas antes do período de gestação adquirem certa imunidade e outros estudos demonstram que a partir do terceiro mês de gestação os ovinos não apresentam abortamento e a única situação observada no caso de não os parirem clinicamente normais é o nascimento de cordeiros 
"débeis" (DUBEY; LINDSAY, 1990; McALLISTER et al., 1996. BUXTON et al., 1998). Com isso a infecção pré gestacional e após o terceiro mês de gestação irão agir como uma "vacina" nas fêmeas, e isso justifica o resultado do estudo onde fêmeas sorologicamente reagentes ao Neospora caninum apresentam menor risco de abortamento pelo parasita que as fêmeas sorologicamente negativas.

Pode-se sugerir que o resultado a respeito da diminuição do risco da presença de secreção vaginal em relação a animais reagentes (Tabela 49), seja devido à razão de que com menos casos de abortamentos as fêmeas irão apresentar esse quadro em menor freqüência, pois grande parte delas que foram submetidas à colheita de material e apresentavam secreção vaginal, haviam abortado anteriormente e não eram reagentes a Neospora caninum.

Ainda seguindo os dados dos estudos dos autores citados anteriormente (DUBEY; LINDSAY, 1990; McALLISTER et al., 1996; BUXTON et al., 1998), podemos observar concordância com o resultado desse estudo que demonstra que animais sororeagentes a Neospora caninum apresentaram fator de risco de 1,80 para casos de repetição de cio (Tabela 52). Os autores relatam que em ovelhas experimentalmente infectadas aos dois meses de gestação foram observados quadros de abortos ou absorção fetal, com isso o grupo de ovelhas do estudo reagentes ao parasita podem ter se infectado no período de até dois meses de gestação e absorvido ou ainda abortado na pastagem feto de pequenas dimensões que não foi localizado e assim caracterizou-se o quadro de repetição de cio ou infertilidade da fêmea.

Com esse dado de aumento do risco de repetição de cio que pode ter ocorrido por absorção fetal, esse estudo não está de acordo com o de Romanelli et al. (2007) que não observaram relação entre ovinos sororeagentes e animais que haviam apresentado problemas reprodutivos. 


\subsection{Toxoplasma gondii}

A toxoplasmose é considerada umas das principais causas de perdas reprodutivas na ovinocultura (FREYRE et al., 1999) e nesse estudo, dentre as enfermidades reprodutivas estudadas, foi a mais prevalente.

A soroprevalência de Toxoplasma gondii possuiu grande variação de acordo com a região estudada. No Brasil inquéritos sorológicos mostram variações entre 7\% e 54\% (OGAWA et al., 2003; MOURA et al. 2007).

O resultado desse estudo, que foi de $29,9 \%$ de animais sororeativos, assemelha-se com outros realizados no estado de São Paulo (MEIRELES; GALISTEO JUNIOR; ANDRADE JUNIOR, 2003; FIGLIUOLO et al., 2004; FELICIO et al., 2008) e é superior a um dos primeiros estudos realizado no estado por Oliveira-Siqueira et al. (1993) e inferior ao de Lopes et al. (2010) na região de Jaboticabal.

Quando observamos resultados de pesquisas realizados em outros estados vemos que no estado do Rio Grande do Sul (LARSSON et al., 1980), Paraná (FREIRE et al., 1995; OGAWA et al., 2003; ROMANELLI et al., 2007), Minas Gerais (CARNEIRO et al., 2006; ROSSI; CABRAL; CORRÊA, 2008; ROSSI et al., 2008), Espírito Santo (BARIONI et al., 2009), Pernambuco (SILVA et al., 2003), Rondônia (CAVALCANTE et al., 2004) e Distrito Federal (UENO et al., 2009) os inquéritos sorológicos apresentaram porcentagem de animais positivos maiores que encontrado nesse estudo sendo a maioria desses estudos realizados em regiões úmidas. Esta pesquisa apresentou prevalência semelhante a estudos realizados em Curitiba (THOMAZ-SOCCOL et al., 2009), Lajes-RN (CLEMENTINO; SOUZA; ANDRADE NETO, 2007) e no estado de Alagoas (PINHEIRO JUNIOR et al., 2009).

Existem estudos que apresentaram prevalências mais baixas realizados principalmente na região Nordeste como o de Amaral, Santos e Rebouças (1978) e Pita Gondim et al. (1999) na Bahia, Albuquerque et al. (2009) no município de Gravatá-PE, Soares et al. (2009) município de Mossoró-RN e Brandão et al. (2009) em São Luiz-MA. Além de outros dois realizados na região Sul por Amaral, Santos e Rebouças (1978) no Rio Grande do Sul e por Moura et al. (2007) no município de Guarapuara-PA que utilizaram ovinos destinados ao abate onde a amostragem foi 
composta por animais jovens que são preteridos pelos abatedouros justificando assim a baixa prevalência.

Os resultados encontrados estão de acordo com os observados no estado de São Paulo, que normalmente são superiores aos realizados na região Nordeste e inferiores aos de outros estados da Região Sudeste e Sul, evidenciando que regiões mais úmidas podem manter os oocistos mais tempo no ambiente, pois o clima e a vegetação contribuem para a formação de um microambiente favorável a manutenção de oocistos viáveis no solo acometendo maior número de animais a infecção toxoplásmica (PITA GONDIM et al., 1999; SILVA et al., 2003).

Foi encontrado ao menos um ovino reagente em $75 \%$ das propriedades onde foram realizadas colheitas, não havendo concordância com outros estudos nacionais que encontraram animais sororeagentes em todos os criatórios estudados (OGAWA et al., 2003; FIGLIUOLO et al., 2004; ROMANELLI et al., 2007; ALBUQUERQUE et al., 2009; BARIONI et al., 2009; PINHEIRO JUNIOR et al., 2009; THOMAZ-SOCCOL et al., 2009; UENO et al., 2009; LOPES et al., 2010). Esse resultado pode ser justificado pois a variação do número de animais submetidos à colheita nos criatórios variou de 1 a 44 e os $25 \%$ dos criatórios onde não foram observados animais reagentes, foram onde se colheu poucas amostras (dos 25\% destes criatórios colheu-se 1,2,2,2,3 e 5 amostras) devido ao baixo número de animais com histórico de problemas reprodutivos, com exceção de um deles onde foram colhidas 18 amostras.

Em outras regiões do Brasil e neste estudo pode-se dizer que o Toxoplasma gondii está amplamente difundido nos criatórios ovinos do estado de São Paulo, independentemente do sistema de criação pois nos sistemas intensivo e semiintensivo foram observados $25 \%$ e $31 \%(P=0,26)$ (Tabela 53$)$ de animais reagentes respectivamente (OGAWA et al., 2003; SILVA et al., 2003; CAVALCANTE et al., 2004; FIGLIUOLO et al., 2004; ROMANELLI et al., 2007; ALBUQUERQUE et al., 2009; BARIONI et al., 2009; BRANDÃO et al., 2009; PINHEIRO JUNIOR et al., 2009; SOARES et al., 2009; THOMAZ-SOCCOL et al., 2009; UENO et al., 2009; LOPES et al., 2010).

Não foi observada suscetibilidade a infecção de acordo com o sexo $(p=0,43)$ (Tabela 53) assim como outros estudos (OGAWA et al., 2003; ALBUQUERQUE et al., 2009; LOPES et al., 2010), na literatura veterinária, no entanto há variabilidade 
de opiniões e resultados pois são encontrados estudos que mostram maior suscetibilidade em machos (SILVA et al., 2003; UENO et al., 2009), e outros nas fêmeas ovinas (CLEMENTINO; SOUZA; ANDRADE NETO, 2007; PINHEIRO JUNIOR et al., 2009).

Em relação às raças ovinas na primeira análise de significância onde foi utilizada a raça Santa Inês como referência foi observado valor de $p=0,006$ para a categoria de ovinos de raças lanadas (Tabela 54) e fator de risco de 0,41 mostrando que esse grupo era menos susceptível a infecção. Ao analisar o fator de risco em relação às raças e utilizando o grupo de lanadas como referência, foi observado que os outros três grupos apresentaram potencial de risco maior à infecção toxoplásmica em relação às lanadas, sendo os do grupo mestiços $(O R=3,00)$ o mais susceptível, seguido dos de raça Santa Inês $(\mathrm{OR}=2,43)$ e por último os da raça Dorper $(\mathrm{OR}=2,03)$ (Tabela 54).

Interpretando esses resultados em relação às características dos criatórios, podemos relacionar que os que possuíam animais mestiços eram os voltados para a ovinocultura de corte onde os animais permaneciam mais tempo a pasto e os cuidados sanitários eram menos rigorosos, assim como alguns que trabalhavam com a raça Santa Inês, sendo que esse grupo possuía também alguns criatórios voltados à produção de matrizes e reprodutores e com isso há decréscimo no fator de risco, já os da raça Dorper e os de raças lanadas eram criatórios mais tecnificados e com maior atenção ao manejo sanitário, até mesmo pelo valor comercial dos animais, voltados mais a produção e venda de matrizes. Outra categoria que podemos avaliar foi a classificação dos criatórios em menos e mais tecnificados. O resultado foi que criatórios que utilizam exclusivamente a monta natural possuíam risco de infecção de 2,28 vezes maior em relação aos que utilizam também inseminação artificial e/ou transferência de embriões (Tabela 62). Na mesma linha de raciocínio da afirmação anterior, ao analisar os resultados deste trabalho com relação à predisposição da raça e a tecnificação do criatório aos resultados de Lopes et al. (2010) e Pinheiro Junior et al. (2009) que relataram um fator de risco maior à infeç̧ão em criações extensivas (menos tecnificadas) em relação às semi-extensivas $(O R=1,68)$ e maior ainda quando se comparou as criações semi-extensivas em relação às intensivas $(\mathrm{OR}=3,17)$ respectivamente, demonstrando que quanto menos intensivo a criação maior será o risco da infecção por Toxoplasma gondii, seja através da água 
contaminada (ROMANELLI et al., 2007; BRANDÃO et al., 2009) alimentação (LOPES et al., 2010) ou oocistos nas pastagens (FRENKEL; RUIZ; CHINCHILLA, 1975).

Outros dois fatores em relação às características dos criatórios onde foi observado significância foram a presença de estábulos $(p=0,087)$ e o fornecimento de alimentação a base de pasto, concentrado e silagem $(p<0,001)$. Os fatores podem estar relacionados, pois a concentração de animais durante um período do dia e fornecimento de alimento em cochos a base de concentrado e silagem aumentam a exposição dos animais a fontes de infecção via oral (WALTNERTOEWS; MONDESIRE; MENZIES, 1991; MAINAR et al., 1996), principalmente em criatórios onde há presença de felinos, que além de contaminar os cochos podem contaminar os depósitos de alimentos quando utilizados para controle de roedores assim como observado por Romanelli et al. (2007). Outra fonte de contaminação seria devido ao tipo de bebedouros utilizados nestes estábulos, onde o tipo balde aumenta o risco de infecção e contaminação por oocistos (BRANDÃO et al., 2009).

Apesar dessa relação entre a estabulação dos ovinos e a contaminação de ambiente, alimentos e água por oocisto, neste estudo não foi observado relação entre a presença de felinos nos criatórios e aumento do risco de infecção assim como em outros estudos (OGAWA et al., 2003; ALBUQUERQUE et al., 2009; BRANDÃO et al., 2009; SOARES et al., 2009) e contrariando os que mostram que a presença de felinos aumenta a prevalência e risco de infecção como o de Pinheiro Junior et al. (2009) e Lopes et al. (2010) que relataram que a presença de felinos aumenta 1,72 e 2,83 o risco de infecção respectivamente.

Nesse estudo foi observado que a presença de aves nos criatórios aumenta o risco da infecção em 2,49 (Tabela 60), pode-se supor que esses animais atraiam maior quantidade de felinos silvestres dos arredores do criatório que poderiam contaminar as instalações, pois foi obtido, no estudo o resultado de que criatórios que não possuem felinos apresentavam maior fator de risco de 1,57 em relação aos que possuíam, supondo que os felinos pertencentes aos criatórios possam limitar o acesso de outros silvestres dos arredores. Outro fator pode ser a quantidade real de criatórios que possuem felinos em contato com os ovinos pois os dados foram obtidos a partir da comunicação dos tratadores e/ou observação no momento da colheita e o que se tem é que em apenas 10 dos 28 criatórios havia a presença de 
felinos, número relativamente baixo e que não leva em conta os casos de felinos predadores ou que vem em busca de alimentos domésticos. Dos sete criatórios onde havia a presença de aves em quatro não havia a presença de felinos pertencentes ao mesmo.

Quanto aos sinais clínicos observado no momento do exame ginecológico, não ocorreu associação de nenhum deles a infecção por Toxoplasma gondii, estando de acordo com Dubey e Kirkbride (1989) que afirmam que em infecções naturais as ovelhas geralmente não apresentam sintomas clínicos, com exceção de raros casos de retenção placentária, que nesse estudo não foi observado a associação, pois as três fêmeas que apresentaram esse quadro não foram sororeagentes à toxoplasmose. No caso da toxoplasmose os autores relatam que a grande maioria dos sororeagentes apenas apresentam formação de cistos em tecidos nervosos e musculares (MARCA et al., 1996; VAUGHAN, 1996).

$\mathrm{Na}$ análise dos distúrbios reprodutivos a presença de toxoplasmose é significante em relação aos casos de abortamentos onde ovinos sororeagentes apresentaram 1,58 mais chances de abortarem que os não reagentes além de possuir o maior número, entre as sete enfermidades estudadas nesta pesquisa, de animais positivos que apresentaram quadro de abortamento sendo 35,3\% (48/136) deles (Tabela 36). Resultados semelhantes ao de Brandão et al. (2009) que em criatórios onde há histórico de abortamentos, o risco da presença do parasita é 2,89 maior que em propriedades onde não há histórico e Romanelli et al. (2007) que mostraram relação entre fêmeas que apresentaram problemas reprodutivos no terço inicial da gestação com sorologia positiva para Toxoplasma gondii. Pinheiro Junior et al. (2009) não observaram associação significativa entre animais com histórico de distúrbios reprodutivos e a infecção por Toxoplasma gondii, embora tenha se observado freqüências mais elevadas em animais com distúrbios em relação aos que não apresentavam essas alterações, sendo elas $33,8 \%$ e $30,8 \%$ respectivamente. Não foi observado também significância entre animais que apresentaram quadro de abortamento, $31,7 \%$ (83/262), ou repetição de cio $52,6 \%$ (10/18) com a presença da infecção.

Mundialmente a toxoplasmose está em destaque quando realizado estudos de abortamentos ovinos, no estudo de Massala et al. (2007) na Itália o parasita foi o mais detectado pela PCR em 292 amostras de feto e 76 de placenta e Pereira- 
Bueno et al. (2004) o diagnosticou em 22,7\% de 176 fetos na Espanha. No Brasil foi indicado como agente etiológico de abortamentos em criatório do estado de Minas Gerais (OKUDA et al., 2007).

A análise de fator de risco mostrou que animais sororeagentes a Toxoplasma gondii, apresentam menor risco de repetir cio que os não reagentes, Pinheiro Junior et al. (2009) não observaram relação entre animais sororeagentes e a repetição de cio. Esse quadro pode ser menos freqüente pois a toxoplasmose clínica ocorre quando as ovelhas se infectam pela primeira vez e o efeito da infecção difere de acordo com o estágio reprodutivo da ovelha e momento da infecção. Esses sinais irão se manifestar em forma de abortamento geralmente em ovelhas até 0 septuagésimo dia de gestação, em fêmeas não gestantes e no terço final de gestação ocorrerá a formação de anticorpos e com isso as manifestações clínicas são raras (BUXTON et al., 1999). Devido à grande disseminação nos rebanhos brasileiros (OGAWA et al., 2003; SILVA et al., 2003; CAVALCANTE et al., 2004; FIGLIOUOLO et al., 2004; ROMANELLI et al., 2007; ALBUQUERQUE et al., 2009; BARIONI et al., 2009; BRANDÃO et al., 2009; PINHEIRO JUNIOR et al., 2009; SOARES et al., 2009; THOMAZ-SOCCOL et al., 2009; UENO et al., 2009; LOPES et al., 2010), uma parte das fêmeas quando entram em gestação já foram expostas anteriormente ao parasita e com isso não apresentam quadro de repetição do cio e aborto, e a parcela de fêmeas que são expostas pela primeira vez durante a gestação apresentarão risco de quadros de abortamento.

Os trabalhos mostram que a prevalência de Neospora caninum, em rebanhos ovinos, em relação à de Toxoplasma gondii geralmente é menor e quando analisase na literatura veterinária a freqüência de animais sororeagentes às duas doenças parasitárias concomitantemente a ocorrência é baixa, como descreve Figliuolo et al. (2004) que obteve 3.5\% de 597 amostras, Romanelli et al. (2007) 5.2\% de 305, Ueno et al. (2009) com 4.67\% de 1.028 e Pandero et al. (2010) com 9\% de 177 amostras. Nesse estudo a ocorrência também foi baixa com apenas 3,74\% (11/294) de animais sororeagentes concomitantemente a Toxoplasma gondii e Neospora caninum 


\subsection{Campilobacter}

Dentre as três espécies de campilobacter capazes de causar distúrbios reprodutivos nos ovinos, Campylobacter jejuni, Campylobacter coli e Campylobacter fetus subespécie fetus (DIKER; ISTANBULLUOGLU, 1986; HEDSTROM et al., 1987; DIKER; SAHAL; AYDIN, 1988; PENNER, 1988; SAHIN et al., 2008), apenas o último não foi isolado nesse estudo sendo o Campylobacter jejuni o mais prevalente, responsável por 66,67\% (7) das amostras positivas, enquanto o Campylobacter coli contribuiu com 22,22\% (2), demonstrando a presença de espécies patogênicas de campilobacter nos rebanhos paulistas. Esses resultados foram semelhantes aos de Stanley et al. (1998) e Jones, Howard e Wallace (1999) de amostras de animais saudáveis, com freqüência de $88,2 \%$ e $90 \%$ para Campylobacter jejuni e 10,8\%, e $8 \%$ para Campylobacter coli respectivamente, sem isolados de Campylobacter fetus subespécie fetus.

A freqüência de isolados (3,65\%) nesse trabalho se aproxima do obtido por Scarcelli et al. (1998) com 2,9\% de positivos sendo todos para Campylobacter jejuni, a mesma espécie responsável por caso de aborto relatado no do Rio Grande do Sul em ovino da raça Texel (VARGAS et al., 2005) sugerindo que essa espécie seja a mais importante para a ovinocultura brasileira. Existe ainda 0 relato do Campylobacter fetus subespécie fetus como agente etiológico de dois casos de abortamento de cordeiros a termo no Rio Grande do Sul (GRESSLER et al., 2008), no estudo não foi isolados essa espécie em nenhuma amostra.

Não foi observado valor significante entre a presença de isolados fecais de Campylobacter spp. em relação ao sexo, raça, tipo de instalação, alimentação, sistema de criação, presença de outras espécies animais e tipo de monta (Tabela $67)$.

As propriedades onde havia a presença de aves, que é um agravante para a infecção (DENNIS, 1967; BROMAN et al., 2002), não apresentaram valor de p significante, no entanto no isolamento de Campilobacter sp em macho da raça Santa Inês ficou claro que sua contaminação se deu pela presença de aves no rebanho e conseqüente contaminação de sua baia, cocho e bebedouro com fezes de aves (Figuras 21 e 22). 
Os resultados contrastam com a afirmação de Diker, Esendal e Akan (2000) que relatam a presença de bovinos nos rebanhos com infecção por Campilobacter $s p$, quadro que não foi observado no estudo, pois nenhum dos isolados foi obtido em propriedades que possuíam criação de bovinos consorciada com a ovinocultura.

Quando analisamos os resultados de Jones, Howard e Wallace (1999) que relatam que fatores de estresse, como parto, desmame, mudança de pasto e sistemas de alimentação de menor qualidade propicia a eliminação da bactéria, notou-se que este quadro não foi observado entre os quatro tipos de alimentação e pelos sistemas de criações analisados nesta pesquisa.

Ao avaliar os sinais clínicos observados durante o exame ginecológico de animais positivos para campilobacteriose, a manifestação significante foi a presença de petéquias na mucosa vaginal que se manifestou em apenas um animal onde foi isolado campilobacter e apresentou valor de $p$ e fator de risco de 0,084 e 7,63 respectivamente.

Quando foi analisada a significância entre a presença de campilobacteriose e os distúrbios reprodutivos (Tabela 67) notou-se que três parâmetros apresentaram valor significante $(p \leq 0,1)$, sendo eles a ocorrência de morte neonatal, nascimento de cordeiros "fraco" e retenção de placenta. O mais significante foi nascimento de cordeiro "fraco" com $\mathrm{p}=0,06$ seguido da morte neonatal com $\mathrm{p}=0,087$ e fator de risco de 3,5 e 6,83 respectivamente, esses dados de nascimento de cordeiro "fraco" e morte neonatal, neste caso, devem ser analisados em conjunto, pois das 4 amostras referentes a nascimento de cordeiro "fraco", em 3 dos casos, em conseqüência da má condição do cordeiro os mesmos vieram a óbito caracterizando quadro de morte neonatal. Esses resultados foram observados por Dennis (1975) que relatou 36,3\% de mortes neonatais em cordeiros decorrentes a infecção por Campylobacter fetus subespécie intestinalis (Campylobacter fetus subespécie fetus).

$\mathrm{Na}$ Nova Zelândia a principal manifestação associada à bactéria é o abortamento (QUINLIVAN; JOOP, 1982; BIRD et al., 1984; MANNERING et al., 2006) onde medidas profiláticas como a vacinação é indicada para diminuir os casos de abortamentos nos rebanhos (BIRD et al., 1984; GUMBRELL; SAVILLET; GRAHAM, 1996; FENWICK et al., 2000; MANNERING et al., 2004), ação que não é recomendada nos rebanhos brasileiros, pois os casos ocorrem esporadicamente como os relatados no Rio Grande do Sul (VARGAS et al., 2005; GRESSLER et al., 
2008), nesse estudo o valor de $p$ para casos de abortamentos não foi significativo $(0,872)$ apesar de que das 9 amostras fecais de fêmea ovina onde foi realizado 0 isolamento em 5 não foram sororeagentes a os outros agentes do estudo e delas 4 fêmeas apresentaram histórico de abortamento. Essa diferença entre a associação dos sinais clínicos pode ocorrer devido à variedade de diferentes cepas da bactéria (COLLINS; LISLE 1984; DELONG; JAWORSKI; WARD, 1996).

Outro fator que pode ter influenciado a não associação com os quadros de abortamentos foi o não isolamento de Campylobacter fetus subespécie fetus nas 255 amostras fecais de fêmeas com distúrbios reprodutivos, assim como nas 69 amostras de Scarcelli et al. (12998), sugerindo que essa espécie seja a mais patogênica para ovinos segundo trabalhos internacionais, pois é com freqüência isolada em estudos de abortamentos (DENNIS, 1975; GUNNARSSON; HURVELL; MOLLERBERG, 1976; BIRD et al., 1984; COLLINS; LISLE, 1984; KIRKBRIDE, 1993; DELONG; JAWORSKI; WARD, 1996; FENWICK et al., 2000; MANNERING et al., 2004; AGERHOLM et al., 2006; SAHIN et al., 2008). Também a sua prevalência é baixa nos rebanhos nacionais ocorrendo apenas o relato de Gressler et al. (2008) na espécie ovina. As espécies de campilobacter isoladas em nosso estudo são também observadas em achados de controle de abatedouros ou pesquisas de ocorrência em rebanhos de animais saudáveis (STANLEY et al., 1998; JONES, HOWARD; WALLACE, 1999; AÇIK; ÇETINKAYA, 2006; OPORTO et al., 2007; SPROSTON et al., 2010). Não é alta a ocorrência destas espécies do isolamento em animais com problemas reprodutivos (KIRKBRIDE, 1993), com exceção a dois estudos realizados no E.U.A. em rebanhos com distúrbios reprodutivos que relataram a incidência de Campylobacter jejuni maior de que Campylobacter fetus subespécie fetus (DELONG; JAWORSKI; WARD, 1996; SAHIN et al., 2008), mostrando a existência de cepas patogênicas de Campylobacter jejuni como observada por Vargas et al. (2005) no Rio Grande do Sul.

A retenção de placenta apresentou $p=0,032$ e fator de risco de 15,36 , não foi observado essa associação em outros estudos e nesse não é possível creditar esse dado pois o número de amostras de animais com retenção de placenta foi baixo $(n=3)$ e apenas um apresentou isolamento positivo para Campylobacter spp..

Analisando as características dos animais onde ocorreram os isolamentos fecais observamos que são compostos por 9 fêmeas e 1 macho, 8 da raça Santa 
Inês e um mestiço pertencente a 5 rebanhos diferentes sendo que de dois rebanhos foram isolados quatro e três amostras respectivamente e dos demais apenas uma amostra, o que prova que a prevalência desta enfermidade é mesmo baixa nos rebanhos brasileiros segundo relatado pelos autores já citados.

A colheita de material do macho da raça Santa Inês que ocorreu isolamento fecal de Campylobacter jejuni se deu devido queixa do proprietário de baixa fertilidade após a cobertura de um lote de fêmeas onde $35 \%(7 / 20)$ não emprenharam. No exame clínico do trado reprodutivo o animal apresentou leve degeneração testicular e circunferência escrotal de $35,5 \mathrm{~cm}$ dentro dos parâmetros raciais (SANTANA; COSTA; FONSECA, 2001), a baixa fertilidade pode ter ocorrido pela presença da bactéria pois Zan Bar et al. (2008) em um dos raros estudos da ação de Campylobacter spp. em sêmen ovino relataram que a presença da bactéria no sêmen in vitro pode ser tóxica pois causou queda da motilidade e vigor espermático, aumento da expressão de receptores FAS, maior presença de defeitos de acrossomo, cabeça solta, aglutinação de cabeça e cauda dobrada. No entanto a baixa taxa de prenhes pode ter ocorrido devido a outro fator que tenha levado a leve degeneração testicular diminuindo a qualidade espermática, deve-se continuar os estudos nesta propriedade. $O$ isolamento da bactéria neste local foi devido ao grande número de aves (DENNIS, 1967; DIKER; ESENDAL; AKAN, 2000; BROMAN et al., 2002), principalmente na baia do reprodutor onde foram observados vários focos de fezes nas paredes, ripas de madeira do chão, cocho e bebedouro (Figuras 21 e 22), aumentando a carga da bactéria no rúmen devido infecção oral e conseqüente eliminação pelo ovino (WALT, 1994).
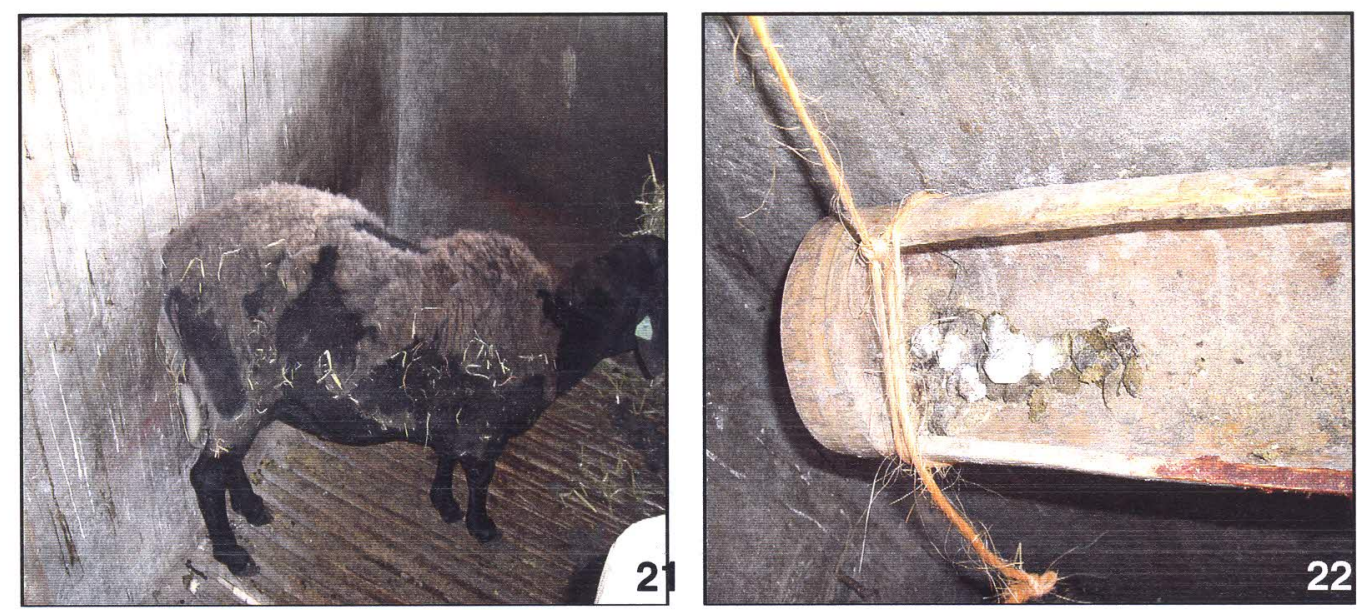

Figura 21 - Baia de aprisco de ovino da raça Santa Inês com isolamento positivo de Campylobacter jejuni, apresentando contaminação de fezes de aves - São Paulo - 2011.

Figura 22 - Cocho de ovino da raça Santa Inês com isolamento positivo de Campylobacter jejuni, apresentando contaminação de fezes de aves - São Paulo - 2011. 
Após 15 meses foi realizada segunda colheita para observar se o quadro persistia e não foi possível o isolamento de qualquer espécie de campilobacter em $0,4 \mathrm{ml}$ de amostra seminal de aspecto leitoso colhido por eletroejaculação e por amostra fecal, concordando com Jones, Howard e Wallace (1999) que relata ocorrer excreção sazonal da bactéria por ovinos, influenciada principalmente pela alimentação ou estresse de manejo ou ainda devido à diminuição da exposição do animal as fezes de aves. Não foi encontrado nenhum relato de isolamento seminal de Campylobacter spp. em sêmen ovino e com isso acredita-se que a bactéria não acometa ovinos na mesma intensidade que é observada em estudos com bovinos onde há rígido controle principalmente em animais de central de colheita de sêmen, sendo as principais espécies o Campylobacter fetus subespécie fetus e Campylobacter fetus subespécie venerealis (HUM; HORNITZKY; BERG, 2009).

Dentre as 9 fêmeas que isolou-se campilobacter nas fezes, 5 delas apresentaram caso de abortamento e 4 de nascimento de cordeiros fracos no histórico reprodutivo. Ao analisar as características dessas duas propriedades onde ocorreram mais de um animal infectado, nota-se grandes diferenças de manejo, instalações e finalidade de criação entre elas. Apesar das diferenças de manejo e criação entre as duas propriedades, pode-se observar um ponto em comum entre elas, estresse dos animais, causado por fatores diferentes. Em uma das propriedades a finalidade de criação era a venda de matrizes para melhoramento genético onde os animais permaneciam estabulados, não havia presença de aves e eram superalimentados apresentando escore corporal variando de 4 a 5 . A superalimentação causou casos de toxemia da prenhez e era visível o estresse calórico dos animais, devido à obesidade conseqüente ao alto fornecimento de concentrado. $O$ estresse pós parto também predispõe o animal a eliminar a bactéria (JONES; HOWARD; WALLACE, 1999). No segundo caso os animais pertenciam a criatório de ovino de corte, criados no sistema semi-intensivo, permanecendo em estábulos durante a noite e alimentados principalmente a pasto. Havia presença de aves e essas fêmeas em especial haviam sido adquiridas de outra propriedade. Elas possuíam escore corporal abaixo de 1 a 2,5 e pariam na propriedade de colheita. A colheita neste criatório deveu-se ao histórico de as fêmeas que pariram cordeiros "fracos". Tal fato se justifica devido à condição corporal das fêmeas, e provavelmente fatores como mudança de propriedade, má alimentação no criatório 
de origem e parto. Estes fatores causadores de quadro de estresse levariam à eliminação da bactéria nas fezes. Analisando essas duas situações pode-se notar que independente do sistema de criação, alimentação ou estado nutricional, o que pode causar a eliminação de Campylobacter spp. por ovinos, são novamente os fatores estressantes que estimulam a proliferação da bactéria no rúmen

Dentre os sinais clínicos colhidos durante o exame clínico dos animais, foi observada significância entre animais com diarréia e isolados de campilobacter ( $\mathrm{p}=$ 0,003 ) com fator de risco de 9,83 concordando com Walt (1994) que relata quadros de diarréia antes do episódio de aborto, no entanto dentre as três fêmeas que apresentaram diarréia e isolamento positivo para campilobacter, apenas uma possuía quadro de abortamento e as duas restantes apresentaram quadro de nascimento de cordeiro fracos que podem ter sido paridos prematuros e com isso apresentaram essa característica.

\subsection{Histophilus somni}

Foi realizado o isolamento em cultura pura de Histophilus somni em amostra de secreção uterina de fêmea ovina da raça Texel que apresentava histórico de infertilidade. Autores afirmam que a bactéria é um organismo transitório da flora vaginal ovina pois a isolaram em animais saudáveis (WALKER; LEAMASTER, 1986) enquanto outros não obtiveram 0 isolamento da mesma em fêmeas ovinas saudáveis (RAHALEY; EDWARDS, 1983).

$\mathrm{Na}$ fêmea do estudo foi observado quadro de endometrite com secreção de odor fétido, semelhante ao descrito na Austrália causada pelo Histophilus somni (RAHALEY; WHITE, 1977). A bactéria foi relatada como causadora de quadro de vulvite em animais naturalmente infectados na Irlanda e ao utilizarem as cepas desses animais infectados em animais sadios foi observado o mesmo quadro de vulvite (BALL; KENNEDY; ELLIS, 1991).

Além desse relato a bactéria já foi associada a casos de perdas neonatais (RAHALEY; WHITE, 1977), epididimite em carneiros jovens (LOW; GRAHAM, 1985; 
SAUNDERS et al., 2007), aborto (HAJTÓS, 1987) e vulvite (BALL; KENNEDY; ELLIS, 1991).

Com isso acredita-se que O Histophilus somni, foi o agente etiológico da endometrite, que resultou em infertilidade da fêmea que não emprenhou após período de estação de monta no criatório. Não foi observado nenhuma outra bactéria no momento do diagnóstico através do isolamento e o animal apresentou sorologia positiva apenas para toxoplasmose que não esta associada a casos de endometrite em ovinos e sim a de abortamentos, malformações fetais, nascimento de animais prematuros e morte neonatais (MALIK; DEESEN; CRUZ, 1990; ESTEBANREDONDO; INNES, 1997).

\subsection{Outros agentes etiológicos}

Das 294 amostras de soros ovinos colhidas com histórico de problemas reprodutivos, $110(37,4 \%)$ foram negativas às enfermidades estudadas. Conclui-se que há outros agentes etiológicos que podem estar agindo nos rebanhos brasileiros que merecem também atenção assim como as desse estudo. Foi relatada a presença de ovinos sororeagentes a Língua Azul no estado de São Paulo (RIZZO et al., 2010). Micoplasmas, cujo algumas espécies estão relacionadas a distúrbios reprodutivos (KAPOOR; SINGH; PATHAK, 1984; BALL et al., 1985; KIDANEMARIAM et al., 2005), e já foi descrito isolados no trato reprodutivo de ovinos do estado de São Paulo com e sem distúrbios reprodutivos (GREGORY et al., 2004; RIZZO, 2006). Há também relato de abortamento ovino causado por Sarcocystis sp (PESCADOR et al., 2007). Outros agentes como a Chlamydophila abortus, principal causadora de abortos na Europa (DA SILVA; FREITAS; MULLER, 2006), Salmonella, Listeria, Anaplasma phagocytophilum, Escherichia coli, Arcanobacterium pyogenes (DJØNNE, 2007) e nos machos Streptococcus, Staphylococccus, Pseudomonas, Pasteurellas, Arcanobacterium pyogenes, Escherichia coli, (PASTOR, 2006), Chlamydophila abortus (DA SILVA; FREITAS; MULLER, 2006), Ureaplasmas e Micoplasmas responsáveis por casos de balanopostites (KIDANEMARIAM et al., 2005), intoxicações por Astragalus 
lentiginosus e Férula communis (PANTER; JAMES; HARTLEY, 1989; GIL ANAYA et al., 2001), vírus como o da Maedi-Visna (PALFI; GLAVITIS; HAJTÓS, 1989) entre outros podem estar agindo nos rebanhos nacionais.

Devido à expansão da ovinocultura e surgimento de novos criatórios fatores de manejo devem ser levados em consideração até o estabelecimento de boas práticas que proporcionem conforto aos animais. Deve-se dar atenção quanto às instalações, principalmente a largura de porteiras e número suficiente de cochos de alimentação onde a busca por alimentos pode levar a traumas por disputa de espaço e animais gestantes podem abortar.

Ao selecionarmos matrizes e reprodutores deve-se realizar o exame clínico completo pois defeitos anatômicos, como o observado em fêmea ovina do estudo com relato de repetição de cio e que possuía com óstio vaginal estreito que impedia a cópula, ou presença de cicatrizes, como observado nesse estudo devido à distocias, miíses ou suturas para correção de prolapsos uterino, podem comprometer a fertilidade da fêmea.

Há também o aspecto nutricional que é muito importante onde o excesso ou a falta de alimento levará a distúrbios reprodutivos causando casos de abortamento, por exemplo, em casos de raquitismo ou toxemia da prenhez primária ou secundária, falha no desenvolvimento embrionário e conseqüente repetição de cio por superalimentação ou desnutrição (WATSON, 1962; BERARDINELLI et al., 2001; ABECIA et al., 2006; MAVROGIANNI; BROZOS, 2008), nascimento de cordeiros "fracos" e/ou morte neonatal devido ao baixo peso ao nascer por deficiência alimentar durante a gestação (GARDNER et al., 2007) e infertilidade e/ou alterações testiculares devido ao baixo escore corporal, falta de zinco, magnésio e vitamina $A$ que podem levar a atrofia e hipoplasia testicular (LOSTE; RAMOS; SÁEZ, 2001).

Por fim podemos citar variações de temperatura, excesso de exercício, plantas tóxicas, coito no final de gestação (WATSON, 1962; PANTER; JAMES; HARTLEY, 1989; GIL ANAYA et al., 2001; MAVROGIANNI; BROZOS, 2008), além das provas diagnósticas utilizadas, que nem sempre apresentam a mesma sensibilidade e especificidade para detecção dos agentes (NAVARRO et al., 2009).

Devido a essa gama de etiologias dos distúrbios reprodutivos, somente em duas amostras foi possível o isolamento bacteriano de agentes patogênicos, Actinobacillus seminis e Histophilus somni em sêmen e secreção uterina 
respectivamente, nas outras amostras, 16 fetos abortados, 1 útero, 6 secundinas, 4 secreções uterinas, 5 zaragatoas vaginais, 17 amostras de sêmen, 3 zaragatoas prepuciais e em uma amostra de urina, bile, epidídimos direito e esquerdo, pênis, próstata, bexiga, fígado, rins e baço, não ocorreram isolamento ou foi observado o crescimento de bactérias caracterizando infecção secundária no momento da colheita. As bactérias mais prevalentes nos casos de contaminação foram Staphylcoccus spp. (35), Escherichia coli (28), Bacillus spp. (19) e Streptococcus spp. (16). O que pode ter facilitado a contaminação é que algumas amostras se apresentavam com início de autólise, fetos e secundinas, ou ainda provinda de um meio com uma gama de bactérias, como as secreções uterinas ou ainda no momento da colheita como nos caso da obtenção de sêmen pelo método de vagina artificial ou eletroejaculação onde a contaminação pode ter sido oriunda do prepúcio, mesmo após realização de limpeza com solução fisiológica.

Não houve detecção de nenhum agente pesquisado nas 11 amostras fetais que foram submetidas a PCR, sendo processadas 2 para Brucella spp. e Leptospira sp, 4 para Toxoplasma gondii e Neospora caninum e 5 para Leptospira sp, Chlamydophila spp. e Listeria monocytogenes. Masala et al. (2007) também não detectaram de todas as amostras os agentes etiológicos dos 292 fetos e 76 placentas em pesquisa pela PCR de Coxiella burnetii, Chlamydophila abortus, Salmonella entérica sorovar abortusovis, Toxoplasma gondii e Neospora caninum, apenas $41 \%$ dos fetos e $30,3 \%$ das placentas foram positivas a essas enfermidades. O mesmo ocorreu com Navarro et al. (2009) onde 37,1\% dos fetos ovinos abortados foram negativos a PCR dos seis agentes etiológicos pesquisados. Conclui-se que a técnica de PCR possui sensibilidade e especificidade diferentes para cada enfermidade. 


\section{CONCLUSÕES}

- Há a ocorrência de todas as enfermidades estudadas no estado de São Paulo.

- Toxoplasmose é a enfermidade mais importante com impacto na produção de ovinos no estado de São Paulo devido ao alto risco de abortamento em animais não infectados.

- Neosporose é a enfermidade que com maior ocorrência em locais semiintensivos e está relacionada com sinais de repetição de cio e fêmeas ovinas se mostraram mais susceptíveis a infecção.

- Brucelose é a enfermidade entre as estudadas com menor ocorrência no estado.

- Há relação entre a presença de campilobacteriose e o nascimento de cordeiros fracos.

- Leptospirose foi observada em baixa titulação e a mais prevalente foi a Leptospira australis sorovar australis proveniente de animais silvestres.

- Conclui-se que há outros agentes etiológicos parasitários, bacterianos, virais e fúngicos assim como manejo e nutrição que podem estar agindo nos rebanhos brasileiros e merecem também atenção assim como as desse estudo. 


\section{REFERÊNCIAS}

ABDOLLAHPOUR, G. A review on Leptospirosis. Tehran: University of Tehran, 2010. $41 \mathrm{p}$.

ABECIA, J. A.; SOSA, C.; FORCADA, F.; MEIKLE, A. The effect of undernutrition on the establishment of pregnancy in the ewe. Reproduction Nutrition Development, v. 46, p. $367-378,2006$.

ABECIA, J. A.; LOZANO, J. M.; FORCADA, F.; ZARAZAGA, L. Effect of the level of dietary energy and protein on embryo survival and progesterone production on day eight of pregnancy in Rasa Aragonesa ewes. Animal Reproduction Science, v. 48, p. 209-218, 1997.

ACHA, P. N.; SZYFRES, B. Leptospirosis: In: Zoonoses and

Communicable Diseases Common to Man and Animals. Washington:OPAS, 1989. p. 93-97. (Scientific Publication, n. 503).

AÇIK, M. N.; ÇETINKAYA, B. Heterogeneity of Campylobacter jejuni and Campylobacter coli strains from healthy sheep. Veterinary Microbiology. v. 115, n. 4, p. 370-375, 2006.

ADLER, B.; DE LA PEÑA MOCTEZUMA, A. Leptospira and leptospirosis. Veterinary Microbiology, v. 149, n 3-4, p.287-296, 2010.

AGERHOLM, J. S.; AALBAEK, B.; FOG-LARSEN, A. M.; BOYE, M.; HOLM, E.; JENSEN, T. K.; LINDHARDT, T.; LARSEN, L. E.; BUXTON, D. Veterinary and medical aspects of abortion in Danish sheep. Acta Pathologica Microbiologica et Immunologica Scandinavica, v. 114. n. 2, p. 146, 2006.

AGRESTI, A. Categorical data analysis. 2. ed. New York: Wiley-Interscience, 2002

AGUIAR, D. M.; CAVALCANTE, G. T.; CANON-FRANCO, W. A.; RODRIGUES, A. A. R.; CHIEBAO, D. P.; LABRUNA, M. B.; CAMARGO, L. M. A.; GENNARI, S. M. Prevalência de anticorpos anti-Neospora caninum em bovinos, ovinos e cães da Amazônia Ocidental Brasileira, Estado de Rondônia. In: FORUM BRASILEIRO DE ESTUDOS SOBRE NEOSPORA CANINUM, 2005, São Paulo. Anais... São Paulo: [s.l.], 2005. p. 33-35.

ALBUQUERQUE, P. P. F.; SOUZA NETO, O. L.; SANTOS, A. S.; FENANDES, E. F. T. S.; FARIA, E. B.; MORAES, E. P. B. X.; RABELO, S. S. A.; SILVA, L. B. G.; MOTA, R. A. Prevalência de Anticorpos lgG anti-Toxoplasma gondii e Fatores de Risco Associados à Infecção em Caprinos e Ovinos no Município de Gravatá, PE. In: JORNADA DE ENSINO, PESQUISA E EXTENSAO - JEPEX, 9., 2009, Recife.

Anais... Disponível em: $<$ http://www.eventosufrpe.com.br/jepex2009/cd/resumos/R0157-1.pdf>. Acesso em: 3 jan. 2011. 
ALONSO, A.; DÍAZ, P. M.; RODRÍGUEZ, V. A.; ARIAS, M. P.; MISIUNAS, S. B.; CARCEDO, J. A.; MENAJOVSKY, J. R. J. Prevalencia de brucelosis caprina y ovina en majadas de la región centro de Pampa de Achala (Córdoba). Revista Argentina de Producción Animal, v. 27, p. 340-341, 2007. Suplemento 1.

AL-KATIB, W. A.; DENNIS, S. M. Early sequential findings in the genitalia of rams experimentally infected with Actinobacillus seminis. New Zealand Veterinary Journal, v. 56, n. 2, p. 50-54, 2008 a.

AL-KATIB, W. A.; DENNIS, S. M. Pathological changes in accessory sex organs of rams following experimental infection with Actinobacillus seminis. New Zealand Veterinary Journal, v. 56, n. 6, p. 319-325, 2008b.

AL-KATIB, W. A.; DENNIS, S. M. Epididymal and testicular lesions in rams following experimental infection with Actinobacillus seminis. New Zealand Veterinary Journal, v. 55, n. 3, p. 125-129, 2007.

AL-KATIB, W. A.; DENNIS, S. M. Experimental transmission of Actinobacillus seminis infection to rams. The Veterinary Record, v. 175, n. 5, p. 143-147, 2005.

AL-MAJALI, A. M.; JAWASREH, K. I.; TALAFHA, H. A.; TALAFHA, A. Q. Neosporosis in Sheep and Different Breeds of Goats from Southern Jordan: Prevalence and Risk Factors Analysis. American Journal of Animal and Veterinary Sciences, v. 3, n. 2, p. 47-52, 2008.

AL-MAJALI, A. M.; MAJOK, A. A.; AMARIN, N. M.; AL-RAWASHDEH, O. F. Prevalence of, and risk factors for, brucellosis in Awassi sheep in Southern Jordan. Small Ruminant Research, v. 73, p. 300-303, 2007.

AL-TALAFHAH, A. H.; LAFI, S. Q.; AL-TARAZI, Y. Epidemiology of ovine brucellosis in Awassi sheep in Northern Jordan. Preventive Veterinary Medicine, v. 60, p. 297306, 2003.

ALTON, G. G.; JONES, L. M.; ANGUS, R. D.; VERGER, J. M. Techniques for the brucellosis laboratory. Paris: INRA, 1976. 109 p.

AMARAL, V.; SANTOS, S. M.; REBOUÇAS, M. M. Sobre a prevalência de anticorpos antitoxoplasma em soros de caprinos e ovinos procedentes respectivamente, dos estados da Bahia e Rio Grande do Sul, Brasil. O Biológico, v. 44, n. 12, p. 331-340, 1978

ANDREANI, E.; TOLARI, F.; FARINA, R. Experimental infection in sheep with Leptospira interrogans serotype hardjo. British Veterinary Journal, v. 139, n. 2, p. 165-170, 1983.

ANDRÉS, S.; JIMENÉZ, A.; SÁNCHEZ, J.; ALONSO, J. M.; GÓMEZ, L.; LÓPEZ, F.; REY, J. Evaluation of some etiological factors predisposing to diarrhoea in lambs in "La Serena" (Southwest Spain). Small Ruminant Research, v. 70, p. 272-275, 2007. 
ANDREWS, J. J.; ANDERSON, T. D.; SLIFE, L. N.; STEVENSON, G. W. Microscopic lesions associated with the isolation of Haemophilus somnus from pneumonic bovine lungs. Veterinary Pathology, v. 22, p. 131-136, 1985.

ANGEN, Ø.; AHRENS, P.; KUHNERT, P.; CHRISTENSEN, H.; MUTTERS, R. Proposal of Histophilus somni gen. nov., sp. nov. for the three species incertae sedis 'Haemophilus somnus', 'Haemophilus agni' and 'Histophilus ovis'. International Journal of Systematic and Evolutionary Microbiology, v. 53, p. 1449-1456, 2003.

ARSENAULT, J.; GIRARD, C.; DUBREUIL, P.; BÉLANGER, D. Lack of evidence of Brucella ovis infection in rams in Quebec. The Canadian Veterinary Journal, v. 45, p. 312-314, 2004.

AZEVEDO, S. S.; ALVES, C. J.; ANDRADE, J. S. L.; SANTOS, F. A.; FREITAS, T. D.; BATISTA, C. S. A. Isolation of Leptospira spp. from kidneys of sheep at slaughter. Arquivos do Instituto Biológico de São Paulo, v. 71, n. 3, p. 383-385, 2004a.

AZEVEDO, S. S.; ALVES, C. J.; ANDRADE, J. S. L.; BATISTA, C. S. A.; CLEMENTINO I. J.; SANTOS, F. A. Ocorrência de aglutininas anti-Leptospira em ovinos do estado do Rio Grande do Norte, Brasil. Revista Brasileira Ciência Veterinária, v. 11, n. 3, p. 167-170, 2004b.

AZEVEDO, S. S.; ALVES, C. J.; BATISTA, C. S. A.; CLEMENTINO, I. J.; SANTOS, F. A.; ALVES, F. A. L. Ocorrência de anticorpos anti-Brucella ovis em ovinos procedentes de quatro municípios do estado do Rio Grande do Norte, Brasil. Agropecuária Técnica, v.25, n.2, p.45-50, 2004c.

AZNAR, R.; ALACÓN, B. PCR detection of Listeria monocytogenes: a study of multiple factors affecting sensitivity. Journal of Applied Mcrobiology, v. 95, p. 958966, 2003.

BAGLEY; C. V.; HEALEY, M. C. Epididymitis in range and purebred rams. 1997. Disponível em:

<http://extension.usu.edu/files/publications/factsheet/AH_Sheep_14.pdf>. Acesso em: 20 jan. 2011.

BAHAMAN, A. R.; IBRAHIM, A. L.; ADAM, A. Serological prevalence of leptospiral infection in domestic animals in west Malaysia. Epidemiology and Infection, v. 99, p. 379-392, 1987.

BAHAMAN, A. R.; MARSHALL ,R. B.; BLACKMORE, D. K.; HATHAWAY, C. Isolation of Leptospira interrogans serovar hardjo from sheep in New Zealand. New Zealand Veterinary Journal, v. 28, n. 8, p. 171, 1980.

BALL, H. J.; KENNEDY, S.; ELLIS, W. A. Experimental reproduction of ovine vulvitis with bacteria of the haemophilus/histophilus group. Research in Veterinary Science, v. 50, p. 81-85, 1991. 
BALL, H. J.; MCCAUGHEY, W. J.; KENNEDY, S.; McLOUGHLI, M. Experimental intrauterine inoculation of pregnant ewes with ureaplasmas. Veterinary Research Communications, v. 9, n. 1, p. 35-43, 1985.

BARBER, J. S.; GASSER, R. B.; ELLIS, J.; REICHEL, M. P.; McMILLAN, D.; TREES, A. J. Prevalence of antibodies to Neospora caninum in different canid populations. The Journal of Parasitology, v. 83, n. 6, p. 365-367, 1997.

BARIONI, G.; TESOLINE, P.; BELTRAME, M. A. N.; PEREIRA, L. V.; GUMIEIRO, M. V. Soroprevalência da toxoplasmose em ovinos da raça Santa Inês nos municípios da Grande Vitória-ES. Ciência Animal Brasileira, p. 714- 719, 2009. [OnLine]. Suplemento 1 do trabalho apresentado no Anais do VIII Congresso Brasileiro de Buiatria, Belo Horizonte - MG, 2009. Disponível em:

<http://www.revistas.ufg.br/index.php/vet/article/viewArticle/7889/5730>. Acesso em: 06 jun. 2010.

BARRATT, J.; QASSAB, S. A.; REICHEL, M. P.; ELLIS, J. T. The development and evaluation of a nested PCR assay for detection of Neospora caninum and Hammondia heydorni in feral mouse tissues. Mollecular and Cellular Probes, v. 22, n. 4, p. 228-233, 2008.

BÁRTOVÁ, E.; SEDLÁ K, K.; LITERÁ K, I. Toxoplasma gondii and Neospora caninum antibodies in sheep in the Czech Republic. Veterinary Parasitology, v. 161, p. 131132, 2009.

BAYNES; I. D.; SIMMONS, G. C. Ovine epididymitis caused by Actinobacillus seminis N. sp. Australian Veterinary Journal, v. 36, p. 454-459, 1960.

BAYNES; I. D.; SIMMONS, G. C. Clinical and pathological studies of Border Leicester rams naturally infected with Actinobacillus seminis. Australian Veterinary Journal, v. 44, p. 339-343, 1968.

BENKIRANE, A. Ovine and caprine brucellosis: World distribution and control/eradication strategies in West Asia/North Africa region. Small Ruminant Research, v. 62, p. 19-25, 2006.

BERARDINELLI, J. G.; WENG, J.; BURFENING, P. J.; ADAIR, R. Effect of excess degradable intake protein on early embryonic development, ovarian steroids, and blood urea nitrogen on days $2,3,4$, and 5 of the estrous cycle in mature ewes.

Journal of Animal Science, v. 79, p.193-199, 2001.

BIBERSTEIN, E. L.; McGOWAN, B.; OLANDER, H.; KENNEDY, P. C. Epididymitis in rams. Studies on pathogenesis. Cornell Veterinarian Medicine, v. 54, p. 27-41, 1964.

BIRD, M. M. E.; STEPHENS, D. J.; WALL, E. P.; LISLE, G. W. Serology of Campylobacter fetus fetus strains from four outbreaks of ovine abortion. New Zealand Veterinary Journal, v. 32, n. 1-2, p. 14-17, 1984. 
BLACKMORE, D. K.; BAHAMAN, A. R.; MARSHALL, R. B. The epidemiological interpretation of serological responses to leptospiral serovars in sheep. New Zealand Veterinary Journal, v. 30, n. 4, p. 38-42, 1982.

BLEWETT, D. A.; WATSON, W. A. The epidemiology of ovine toxoplasmosis. II. Possible sources of infection in outbreaks of clinical disease. British Veterinary Journal, v. 139, n. 6, p. 546-555, 1983.

BLOBEL, H.; FERNANDES, J. C. T.; MIES FILHO, A.; RAMOS, A. A.; TREIN, E. J. Estudos sobre a etiologia da epididimite ovina no Rio Grande do Sul. Pesquisa Veterinária Brasileira, v. 7, p. 1-4, 1972.

BRANDÃO, V. M.; COSTA, F. B.; SILVA, I. A.; SILVA, D. F.; DIAS, I. C. L.; GENNARI, S. M.; SOUZA, J. R. S. T.; SILVA, M. I. S. Levantamento soroepidemiológico da toxoplasmose em ovinos na ilha de São Luís - MA. Ciência Animal Brasileira, p. 720-725, 2009. [OnLine]. Suplemento 1 do trabalho apresentado no Anais do VIII Congresso Brasileiro de Buiatria, Belo Horizonte - MG, 2009. Disponível em:

<http://www.revistas.ufg.br/index.php/vet/article/viewArticle/7889/5730>. Acesso em: 06. Jun. 2010.

BROWN, G. M.; PIETZ, D. E.; PRICE, D. A. Studies on the transmission of Brucella ovis infection in rams. The Cornell Veterinarian, v. 63, n. 1, p. 29-40, 1973.

BROWN, G. M.; RANGER, C. R.; KELLEY, D. J. Selective media for the isolation of Brucella ovis. The Cornell Veterinarian, v. 61, n. 2, p. 265-280, 1971.

BROMAN, T.; PALMGREN, H.; BERGSTROM, S.; SELLIN, M.; WALDENSTROM, J.; DANIELSSON-THAM, M. L.; OLSEN, B. Campylobacter jejuni in black-headed gulls (Larus ridibundus): prevalence, genotypes, and influence on $C$. jejuni epidemiology. Journal of Clinical Microbiology, v. 40, n. 12, p. 4594-4602, 2002.

BRUERE, A. N.; WEST, D. M.; MACLACHLAN, N. J.; EDWARDS, J. D.; CHAPMAN, H. M. Genital infection of ram hoggets associated with a gram-negative pleomorphic organism. New Zealand Veterinary Journal, v. 25, n. 7, p. 191-193, 1977.

BUCKRELL, B. C.; McEWEN, S. A.; JOHNSON, W. A.; SAVAGE, N. C. Epididymitis caused by Brucella ovis in southern Ontario sheep flock.The Canadian Veterinary Journal, v. 26, n. 10, p. 293-296, 1985.

BUDDLE, M. B. Studies on Brucella ovis (n.sp.), a cause of genital disease of sheep in New Zealand and Australia. Journal of Hygienic, v. 54, n. 3, p.351, 1956.

BUDDLE, M. B.; BOYES, B. W. A Brucella mutant causing genital disease of sheep in New Zealand. Australian Veterinary Journal, v. 29, p.145-153, 1953.

BULGIN, M. S. Epididymitis in rams and lambs. Veterinary Clinics: Food Animal Practice, v. 6, p. 683-690, 1990. 
BULGIN, M. S.; ANDERSON, B. C. Association of sexual experience with isolation of various bacteria in cases of ovine epididymitis. Journal of the_American Veterinary Medical Association, v. 182, p. 372-374, 1983

BULGIN, M. S.; BRUSS, M. L.; ANDERSON, B. C. Methods for control of lamb epididymitis in large purebred folcks. Journal American Veterinary Medical Association, v. 196, p. 1110-1115, 1990.

BURGESS, G. W.; McDONALD, J. W.; NORRIS, M. J. Epidemiological on ovine brucellosis in selected ram flocks. Australian Veterinary Journal, v. 59, n. 2, p. 45$47,1982$.

BUSSAB, W. O.; MORETTIN, P. A. Estatística básica. 5. ed. São Paulo: Saraiva, 2004.

BUXTON, D.; HENDERSON, D. Infectious abortion in sheep. In Practice, v. 21, n. 7, p. 360-368, 1999.

BUXTON, D.; MALEY, S. W.; THOMSON, K. M.; TREES, A. J.; INNES, E. A. Experimental Infection of Non-pregnant and Pregnant Sheep with Neospora caninum. The Journal of Comparative Pathology, v. 117, p. 1-16, 1997.

BUXTON, D.; MALEY, S. W.; WRIGHT, S. ; THOMSON, K. M.; RAE, A. G.; INNES, E. A. The pathogenesis of experimental Neosporosis in pregnant sheep. The Journal of Comparative Pathology, v. 118, p. 267-279, 1998.

BUXTON, D.; McALLISTER, M. M.; DUBEY, J. P. The comparative pathogenesis of neosporosis. Trends in Parasitology, v. 18 , n. 12, p. 546-552, 2002.

BUXTON, D.; WRIGHT, S.; MALEY, S. W.; RAE, A. G.; LUNDEN , A. ; INNES, E. A. Immunity to experimental neosporosis in pregnant sheep. Parasite Immunology, $v$. 23, p. 85-91, 2001.

CALDAS, E. M.; SAMPAIO, M. B.; VIEGAS, E. A.; VIEGAS, S. A. R. A.; DIAS, E. M. M. Aglutininas antileptospira em ovinos e caprinos na região nordeste do Estado da Bahia. Arquivos da Escola de Veterinária da Universidade Federal da Bahia, v. 8, p. 88-98, 1983.

CAMARGO, M. E. Improved technique of indirect immunofluorescence for serological diagnosis of toxoplasmosis. Revista do Instituto de Medicina Tropical de São Paulo, v. 6, n. 3, p. 117-118, 1974.

CAMERON, R. D. A.; LAUERMAN JUNIOR, L. H. Characteristics of semen changes during Brucella ovis infection in rams. The Veterinary Record, v. 99, n. 12, p. 231233, 1976.

CAMPERO, C. M.; ANDERSON, M. L.; WALKER, R. L.; BLANCHARD, P. C.; BARBANO, L.; CHUI, P.; MARTINEZ, A.; COMBESSIES, G.; BARDON, J. C.; CORDEVIOLA , J. Immunohistochemical identification of Campylobacter fetus in 
natural cases of bovine and ovine abortions. Journal of Veterinary Medicine Series B, v. 52, n. 3, p. 138-141, 2005.

CARNEIRO, A. C. A. V. Soroepidemiologia da toxoplasmose caprina e ovina no estado de Minas Gerais. 2006. 134 p. Dissertação (Mestrado em Parasitologia) Instituto de Ciências Biológicas da Universidade Federal de Minas Gerais, Belo Horizonte - MG, 2006. http://www.bibliotecadigital.ufmg.br/dspace/Disponível em: < http://hdl.handle.net/1843/SAGF-6YER4E $>$. Acesso em: 2 jan. 2011.

CAVALCANTE, G. T.; AGUIAR, D. M.; CHIEBAO, D. P.; MEIRELES, L. R.; ANDRADE JUNIOR, H. F.; CAMARGO, L. M. A.; LABRUNA, M. B.; RUIZ, V. L. A.; GENNARI, S. M. Ocorrência de anticorpos anti-Toxoplasma gondii em humanos e animais domésticos da zona rural do município de Monte Negro, Rondônia. Revista Brasileira de Parasitologia Veterinária, v. 13, p. 217, 2004. Suplemento 1.

CELEBI, O.; ATABAY, H. I. Seroepidemiological investigation of brucellosis in sheep abortions in Kars, Turkey. Tropical Animal Health and Production, v. 41, p. 115119, 2009.

CICERONI, L.; LOMBARDO. D.; PINTO, A.; CIARROCCHI, S.; SIMEONI, J. Prevalence of antibodies to Leptospira serovars in sheep and goats in Alto AdigeSouth Tyrol. Journal of Veterinary Medicine. B, Infectious Diseases and Veterinary Public Health, v. 47, n. 3, p. 217-223, 2000.

CLARK, A. M. Leptospira hardjo infection in sheep. The Veterinary Record, v. 134, n 11, p. 283, 1994.

CLARK, B. L.; MONSBOURGH, B. L. The prevalence of Campylobacter fetus in the gall bladder of sheep. Australian Veterinary Journal, v. 55, p. 42-43, 1979.

CLEMENTINO, I. J.; ALVES, C. J.; AZEVEDO, S. S.; PAULIN, L. M.; MEDEIROS, K. A. Inquérito soro-epidemiológico e fatores de risco associados à infecção por Brucella ovis em carneiros deslanados do semi-árido da Paraíba. Pesquisa Veterinária Brasileira, v. 27, n. 4, 2007.

CLEMENTINO, M. M.; SOUZA, M. F.; ANDRADE NETO, V. F. Seroprevalence and Toxoplasma gondii-lgG avidity in sheep from Lajes, Brazil. Veterinary Parasitology, v. 146, p. 199-203, 2007.

COELHO, A. M.; COELHO, A. C.; ROBOREDO, M.; RODRIGUEZ, J. A case-control study of risk factors for brucellosis seropositivity in Portuguese small ruminants herds. Preventive Veterinary Medicine, v. 82, p. 291-301, 2007.

COLLINS, D. M.; LISLE, G. W. Typing of "Campylobacter fetus fetus" isolated from sheep abortions in New Zealand. New Zealand Veterinary Journal, v. 33, p. 52-53, 1984.

CORBELLINI, L. G.; SMITH, D. R.; PESCADOR, C. A.; SCHMITZ, M.; CORREA, A.; STEFFEN, D. J.; DRIEMEIER, D. Herd-level risk factors for Neospora caninum 
seroprevalence in dairy farms in southern Brazil. Preventive Veterinary Medicine, v. 74 , p. 130-141, 2006.

CORNELIUS, A. J.; NICOL, C.; HUDSON, J. A. Campylobacter spp. in New Zealand raw sheep liver and human campylobacteriosis cases. International Journal of Food Microbiology, n. 99, p. 99-105, 2005.

COSTARELLI, S.; MANUALI, E.; ELENI, C.; CROTTI, S.; FILIPPINI, G.; MOSCATI, L.; ANTENUCCI, P.; MARROCCHI, A.; MAGNINO, S. Ruolo di Neospora caninum negli episode abortivi di un allevamento ovi-caprino Dell'Italia Centrale. Large Animals Review, v. 10, n. 2, p. 53-57, 2004.

COUSINS, D. V.; ELLIS, T. M.; PARKINSON, J.; McGLASHAN, C. H.; Evidence of sheep as a maintenance host for Leptospira interrogans serovar hardjo. The Veterinary Record, n. 124, p. 123-124, 1989.

DA SILVA, F. G.; FREITAS, J. C.; MULLER, E. Chlamydophila abortus em animais de produção. Ciência Rural, v. 36, n. 1, p. 342-348, 2006.

DAVISON, H. C.; GUY, C. S.; MCGARRY, J. W.; GUY, F.; WILLIAMS, D. J.; KELLY, D. F.; TREES, A. J. Experimental studies on the transmission of Neospora caninum between cattle. Research in Veterinary Science, v. 70, n. 2, p. 163-168, 2001.

DAVISON, J. N.; HIRSCH, D. C. Leptospirosis in lambs. Journal American Veterinary Medical Association, v. 176, n. 2, p. 124-125, 1980.

DELONG, W. J.; JAWORSKI, M. D.; WARD, A. C. S. Antigenic and restriction enzyme analysis of Campylobacter spp associated with abortion in sheep American Journal Veterinary Research, v. 57, n. 2, p. 163-167, 1996.

DENNIS, S. M. The possible role of the raven in the transmission of ovine vibriosis. Australian Veterinary Journal, v. 43, p. 45-48, 1967.

DENNIS, S. M. Perinatal lamb mortality in Western Australia: 5. Vibrionic infection. Australian Veterinary Journal, v. 51, p. 11-13, 1975.

DIBARRAT, J. A.; APARECIDO, E. D.; REYNOSO, B. A.; APARICIDO, B. D.; GUTIÉRREZ, V. R. T.; PÉREZ, J. T. Inducción experimental de epididimitis en ovinos por inoculación intrauretral con Actinobacillus seminis: estudio bacteriológico, serológico e histopatológico. Revista Técnica Pecuaria en México, v. 44, p. 257267, 2006.

DIKER; K. S.; ESENDAL, O. M.; AKAN, M. Epidemiology of ovine Campylobacter infection determined by numerical analysis of electrophoretic protein profiles. Journal of Veterinary Medicine B, v. 47, p. 739-743, 2000.

DIKER; K. S.; ISTANBULLUOGLU, E. Ovine abortion associated with Campylobacter jejuni. The Veterinary Record, v. 118, n. 15, p. 307, 1986. 
DIKER, K. S.; SAHAL, M.; AYDIN, N. Ovine abortion associated with Campylobacter coli. The Veterinary Record, v. 122, n. 4, p. 87, 1988.

DJØNNE, B. Infections and perinatal diseases - a comparative Overview. Acta Veterinary Scandinavica, v. 49, supl. 1, p. 20-24, 2007.

DRAGSET, K. I.; HEKTOEN, L.; OPHEIM, M. Causes of perinatal death in lambs in Oppdal and Rennebu, Norway. Acta Veterinary Scandinavica, v. 49, supl. 1, p. 6, 2007.

DUBEY, J. P. Status of toxoplasmosis in sheep and goats in the United States. Journal of American Veterinary Medical Association, v. 196, n. 2, p. 259-262, 1990.

DUBEY, J. P. Refinement of pepsin digestion method for isolation of Toxoplasma gondii from infected tissues. Veterinary Parasitology, v. 74, p. 75-77, 1998.

DUBEY, J. P.; LINDSAY, D. S. Neopora caninum induced abortion in sheep. Journal Veterinary Diagnostic Investigation, v. 2, n. 3, p. 230-233, 1990.

DUBEY, J. P.; KIRKBRIDE, C. A. Enzootic toxoplasmosis in sheep in north-central United States. Journal Parasitology, v. 75, n. 5, p. 673-676, 1989.

ELLIS, W. A. Leptospirosis as a cause of reproductive failure. Veterinary Clinics of North America: Food Animal Practive, v. 10, n. 3, p. 463-478, 1994.

ELLIS, G. R.; PARTINGTON, D.L.; HINDMARSH, M.; BARTON, M. D. Seroprevalence to Leptospira interrogans serovar hardjo in Merino stud rams in South Austrália. Australian Veterinary Journal, v. 71, n. 7, p. 203-206, 1994.

ELLIS, W. A.; BRYSON, D. G.; NEILL, S. D.; McPARLAND, P.J.; MALONE, F. E. Possible involvement of leptospires in abortion, stillbirths and neonatal deaths in sheep. The Veterinary Record, v. 112, n. 13, p. 291-293, 1983.

EPSTEIN, B.; CIPRIAN, F.; ANDREATA, J. N.; BACIGALUPO, N. R. Estudios de la patologia y microbiologia espontanea y experimental en ovinos machos provocada por Brucilla ovis. Facultad de Ciências Veterinarias, Universidad Nacional de La Plata, n. 3, p. 1-47, 1964.

ERASMUS, J. A. The usefulness of the API $20 \mathrm{E}$ classification system in the identification of Actinobacillus actinomycetem comitans, Actinobacillus seminis and Pasteurella haemolytica. Onderstepoort Journal of Veterinary Research, v. 50, p. 97-99, 1983.

ERASMUS, J. A.; WET, J. A. L.; PROZESKY, L. Actinobacillus seminis infection in a Walrich ram. Journal of the South African Veterinary Association, v. 53, n. 2, p. 129, 1982.

ESCÓCIO, C. F.; GENOVEZ, M. E.; CASTRO, V.; PAULIN, L. M. S.; PIATTI, R. M.; OKUDA, L. H.; GABRIEL, F. H. L.; CHIEBAO, D. P.; FELICIO, P. S.; 
ALMEIDA, M. C. S. Perfil sanitário de rebanhos ovinos criados exclusivamente ou consorciados com bovinos na região de Sorocaba - São Paulo. In: CONGRESSO BRASILEIRO DE MEDICINA VETERINÁRIA - CONBRAVET, 35., 2008, Gramado, RS. Anais... 2008. Disponível em:

<http://www.sovergs.com.br/conbravet2008/anais/cd/resumos/R0693-2.pdf>. Acesso em: 3 jan. 2001.

ESTEBAN-REDONDO, I.; INNES, E. A. Toxoplasma gondii infection in sheep and cattle. Comparative Immunology Microbiology Infectious Diseases, v. 20, n. 2, p. 191-196, 1997.

ESTEBAN-REDONDO, I.; MALEY, S. W.; THOMSON, K.; NICOLL, S.; WRIGHT, S.; BUXTON, D.; INNES, E. A. Detection of T. gondii in tissues of sheep and cattle following oral infection. Veterinary Parasitology, v. 86, n. 3, p. 155-171, 1999.

EVERETT, K. D. E.; ANDERSEN, A. A. Identification of nine species of the Chlamydiaceae using PCR-RFLP. International Journal of Systematic Bacteriology, v. 49, p. 803-813, 1999.

FAINE, S. (Ed.). Guidelines for the control of leptospirosis, Geneva: WHO, 1982. p. 1-171. (WHO Offset Publication, 67).

FARIAS, E.; CAVALCANTI, E.; MADEIROS, E.; PINHEIRO JÚNIOR, J.; AZEVEDO, S.; ATHAYDE, A.; MOTA, R. Risk factors associated with Neospora caninum seropositivity in sheep from the State of Alagoas, in the Northeast Region of Brazil. The Journal of Parasitology, v. 96, n. 1, p. 197-199, 2009.

FAVERO, A. C. M.; PINHEIRO, S. R.; VASCONCELLOS, S. A.; MORAIS, Z. M.; FERREIRA, F.; NETO, J. S. F. Sorovares de leptospiras predominates em exames sorológicos de bubalinos, ovinos, caprinos, equinos, suínos e cães de diversos estados brasileiros. Ciência Rural, v. 32, n. 4, p. 613-619, 2002.

FELICIO, P. S.; VILLALOBOS, E. M. C.; LARA, M. C. C. S. H.; CUNHA, E. M. S.; NOGUEIRA, A. H. C.; CHIEBAO, D. P.; ESCOCIO, C. S.; GABRIEL, F. H. L.; GENOVEZ, M. E. Freqüência de anticorpos anti-Toxoplasma gondii (Nicolle e Manceaux, 1909) em ovinos na região de Sorocaba, São Paulo: dados preliminares. O Biológico, v. 70, n. 2, p. 109, 2008. Apresenntado no 21ª Reunião Anual do Instituto Biológico, 2008.

FENWICK, S. G.; WEST, D. M.; HUNTER, J. E. B.; SARGISON, N. D.; AHMED, F.; LUMSDEN, J. S.; COLLETT, M. G. Campylobacter fetus fetus abortions in vaccinated ewes. New Zealand Veterinary Journal, v. 48, n. 5, p. 155-157, 2000.

FICAPAL, A.; JORDANA, J.; BLASCO, J.M.; MORIYÓN, I. Diagnosis and epidemiology of Brucella ovis infection in rams. Small Ruminant Research, v. 29, p. 13-19, 1998.

FIGLIUOLO, L. P. C.; KASAI, N.; RAGOZO, A. M. A.; DE PAULA, V. S. O.; DIAS, R. A.; SOUZA, S. L. P.; GENNARI, S. M. Prevalence of anti-Toxoplasma gondii and 
anti-Neospora caninum antibodies in ovine from São Paulo State, Brazil. Veterinary Parasitology, v. 123, n. 161-166, 2004.

FIGUEIREDO, H. C. P.; LAGE, A. P.; HIRSCH, C. Campos e carrear - Produtos e serviços veterinário, Londrina - PR. Colheita e remessa de espécimes para 0 diagnóstico laboratorial de doenças infecciosas da reprodução e legislação sanitária internacional para o intercâmbio de sêmen e embriões [aproximadamente 18 telas]. 2010. Disponível em: <http://www.camposecarrer.com.br/laboratorio.asp?cat=3\&sub=30>. Acesso em: 02 jan. 2011.

FOSTER, G.; COLLINS, M. D.; LAWSON, P. A.; BUXTON, D.; MURRAY, F. J.; SIME, A. Actinobacillus seminis as a cause of abortion in a UK sheep flock. The Veterinary Record, v. 24, n. 144, p.479-80, 1999.

FOURIE, P. J.; SCHWALBACH, L. M.; NESER, F. W. C.; GREYLING J. P. C. Relationship between body measurements and serum testosterone levels of Dorper rams. Small Ruminant Research, v. 56, p.75-80, 2005.

FREIRE, R. L.; GIRALDI, N.; VIDOTTO, O.; NAVARRO, I. T. Levantamento soroepidemiológico da toxoplasmose em ovinos da região de Londrina - PR. Arquivo Brasileiro de Medicina Veterinária e Zootecnia, v. 47, n. 4, p. 609-612, 1995.

FRENKEL, J. K; RUIZ, A; CHINCHILLA, M. Soil survival of Toxoplasma oocysts in Kansas and Costa Rica. American Journal of Tropical Medicine and Hygiene, Northbrook, v. 24, p. 439-443, 1975.

FREYRE, A.; BONINO, J.; FALCÓN, J.; CASTELLS, D.; CORREA, O.; CASARETTO, A. The incidence and economic significance of ovine toxoplasmosis in Uruguay. Veterinary Parasitology, v. 81, p. 85-88, 1999.

GAFFURI, A.; GIACOMETTI, M.; TRANQUILLO, V. M.; MAGNITO, S.; CORDIOLI, P.; LANFRANCHI, P. Serosurvey of roe deer, chamois and domestic sheep in the Central Italian Alps. The Journal of Wildlife Diseases, v. 42, n. 3, p. 685-690, 2006.

GARCIA, J. L.; NAVARRO, I. T.; OGAWA, L.; OLIVEIRA, R. C. Soroprevalência do Toxoplasma gondii em suínos, bovinos, ovinos e eqüinos, e sua correlação com humanos, felinos e caninos, oriundos de propriedades rurais do norte do Paraná Brasil. Ciência Rural, v. 29, n. 1, p. 91-97, 1999.

GARDNER, D. S.; BUTTERY, P. J.; DANIEL, Z.; SYMONDS, M. E. Factors affecting birth weight in sheep: maternal environment. Reproduction, v. 133, p. 297-307, 2007.

GENOVEZ, M. E.; SCARCELLI, E.; FACIOLLI, M. R.; CARDOSO, M. V.; TEIXEIRA, S. R. Avaliação bacteriológica de sêmen "in natura" e industrializado de touros.

Revista Brasileira de Reprodução Animal, v. 23, n. 3, p. 403-405, 1999. 
GERRITSEN, M. J.; KOOPMANS, M. J.; OLYHOEK, T. Sheep as maintenance host for Leptospira serovar hardjo subtype hardjobovis. American Journal Veterinary Research, v. 55, n. 9, p. 1232-1237, 1994.

GIL ANAYA, M. C.; GARCÍA RUBIO, L.; ROY PÉREZ, T. J.; PRIETO OREJA, L.; PEÑA VEGA. F. J. Y.; GÓMEZ GORDO, L. Estúdio lesional y ecográfico de las alteraciones testiculares y epididimarias ocasionadas em moruecos trás la intoxicación natural por férula communis. Patologia Animal, XXV, 2001.

(Comunicación 6). Disponível em: < http://www.exopol.com/seoc/docs/7hcvy35t.pdf>. Acesso em: 08 out. 2010.

GILMOUR, N. J. L.; THOMPSON, D. A.; FRESER, J. Vaccination against Vibrio (Campylobacter) fetal fetus infection in sheep in late pregnancy. The Veterinary Record, v. 96, p. 129-31, 1975.

GODFROID, J.; KÄSBOHRER, A. Brucellosisi in the European Union and Norway at the turn of the twenty-first century. Veterinary Microbiology, v. 90, p. 135-145, 2002.

GOMES, M. J. P.; DRIEMEIER, D. BONETTI, A. L.; EIDT, M.; AZABUJA, D. R. Epididimite ovina: isolamento de Actinobacillus seminis, no RS - Brasil, Arquivos da Faculdade de Veterinária, UFRGS, v. 29, n. 1, p. 55-58, 2001.

GORDON, L. M. Isolation of Leptospira interrogans serovar Hardjo from sheep. Australian Veterinary Journal, v. 56, n. 7, p. 348-349, 1980.

GRESSLER, L. T.; KIRINUS, J. K.; MACHADO, G.; PRESTES, D. S.; VARGAS, A. C. Isolamento de Campylobacter fetus subspecie fetus em feto ovino abortado. In: CONGRESSO BRASILEIRO DE MEDICINA VETERINÁRIA, 35., 2008, Gramado, RS. Anais... 2008. Disponível em:

$<$ http://www.sovergs.com.br/conbravet2008/anais/cd/resumos/R0329-2.pdf >. Acesso em: 3 jan. 2011.

GREGORY, L.; METTIFOGO,E.; RIZZO,H.; CARDOSO, M. V.; BUZINHANI, M.; MENEGHINI, R. C. M.; TIMENESKI, J. First Isolation of Ureaplasma sp from ovines sperm and vaginal swab in State of São Paulo - Brazil. In: INTERNATIONAL CONGRESS ON ANIMAL REPRODUCTION, 15., 2004, Porto Seguro, Brasil. Anais... Porto Seguro: ICAR, 2004. v. 1, p. 280.

GREGORY, L.; RIZZO, H.; CARVALHO, A. F.; SCARCELLI, E. P. First isolate from Histophilus somni in sheep with endometritis in São Paulo state, Brazil. In: CONGRESSO MUNDIAL DE BUIATRIA, 26., 2010, Santiago, Chile. Anais... 2010.

GREGORY, L.; RIZZO, H.; MEIRA JUNIOR, E. B. S.; LINS, G. J. V.; LINS, G. P. V.; PINHEIRO, E. S. Relato do primeiro caso de orquite e epididimite unilateral ovina causada por Actinobacillus seminis no estado de São Paulo, Brasil. Revista

Brasileira de Reprodução Animal, v. 33, n. 2, p. 105-107, 2009. 
GUMBRELL, R. C.; SAVILLET, D. J.; GRAHAM, C. F. Tactical control of ovine Campylobacter abortion outbreaks with a Bacterin. New Zealand Veterinary Journal, v. 44, n. 2, p. 61-63, 1996.

GUMBRELL, I. R. C.; SMITH, J. M. B. Deoxyribonucleic acid base composition of ovine actinobacilli. Journal General Microbiology, v. 84, p. 399-402, 1974.

GUNNARSSON, A.; HURVELL, B.; MOLLERBERG, L. Isolation of Campylobacter fetus in two herds of sheep in Sweden. Nordisk Veterinaermedicin, v. 28, n. 9, p. 444-451, 1976.

HAJI HAJIKOLAEI, M. R.; GHORBANPOUR, M.; GHARIBI, D.; ABDOLLAPOUR, G. $R$. Serologic study on leptospiral infection in sheep in Ahvaz, southwestern Iran. Iranian Journal of Veterinary Recherch, v. 8, n. 4, p. 333-336, 2007.

HAJTÓS, I. Isolation of Actinobacillus seminis and Histophilus ovis strains from aborted ovine fetuses in Hungary. Acta Veterinaria Hungarica, v. 35, p. 415-425, 1987.

HAJTÓS, I.; FODOR, L.; GLÁVITS, R.; VARGA, J. Isolation and characterization of Actinobacillus seminis strains from ovine semen samples and epididymitis. Journal of Veterinary Medicine B, v. 34, p. 138-147, 1987.

HARRIS, F. W.; JANZEN, E. D. The Haemophilus somnus disease complex (haemophilosis): a review. Canadian Veterinary Journal, v. 30, p. 816-822, 1989.

HARTLEY, W. J. Ovine Leptospirosis. Australian Veterinary Journal, v. 28, p. 154157, 1952.

HARTLEY, W. J.; JEBSON, J. L.; McFARLANE, D. New Zealand tipe II abortion in ewes. Australian Veterinary Journal, v. 30, n. 7, p. 216-218, 1954.

HÄSSIG, M.; SAGER, H.; REITT, K.; ZIEGLER, D.; STRABEL, D.; GOTTSTEIN, B. Neospora caninum in sheep: a herd case report. Veterinary Parasitology, v. 117, p. 213-220, 2003.

HATHAWAY, S. C.; MARSHALL, R. B. Experimental infection of sheep with Leptospira interrogans serovars hardjo and balcanica. New Zealand Veterinary Journal, v. 27, n. 9, p. 197-197, 1979.

HATHAWAY, S. C.; WILESMITH, J. W.; LITTLE, T. W.Some population parameters of Leptospira interrogans serovar hardjo infection in sheep. The Veterinary Record, v. 114, n. 17, p. 428-429, 1984.

HEATH, P. J.; DAVIES, I. H.; MORGAN, J. H.; AITKEN, I. A. Isolation of Actinobacillus seminis from rams in United Kingdom. The Veterinary Record, v. 129, p. 304-307, 1991. 
HEDSTROM, O. R.; SONN, R. J.; LASSEN, E. D.; HULTGREN, B. D.; CRISMAN, R. O.; SMITH, B. B.; SNYDER, S. P. Pathology of Campylobacter jejuni abortion in sheep. Veterinary Pathology, v. 24, n. 5, p. 419-426, 1987.

HELMICK, B.; OTTER, A.; MCGARRY, J.; BUXTON, D. Serological investigation of aborted sheep and pigs for infection by Neospora caninum. Research in Veterinary Science, v. 73, p. 187-189, 2002.

HERRMANN, G. P.; LAGE, A. P.; MOREIRA, E. C.; HADDAD, J. P. A.; RESENDE, J. R.; RODRIGUES, R. O.; LEITE, R. C. Soroprevalencia de aglutininas antiLeptospiras spp. Em ovinos nas Mesorregiões Sudeste e Sudoeste do Estado Rio Grande do Sul, Brasil. Ciência Rural, v. 34, n. 2, p. 443-448, 2004.

HIDE, G.; MORLEY, E. K.; HUGHES, J. M.; GERWASH, O.; ELMAHAISHI, M. S.; ELMAHAISHI, K. H.; THOMASSON, D.; WRIGHT, E. A.; WILLIAMS, R. H. MURPHY, R. G.; SMITH, J. E. Evidence for high levels of vertical transmission in Toxoplasma gondii. Parasitology, v. 136, p. 1877-1885, 2009.

HIGGINS, R.; GODBOUT-DELASALLE, F.; MESSIERS, S.; COUTURE, Y.; LAMOTHE, P. Isolation of Histophilus ovis from vaginal discharge in ewes in Canada. The Canadian Veterinary Journal, v. 22, p. 395-396, 1981.

HIRSH, D. C. Campylobacter-Arcobacter (Reproductive tract). In: HIRSH, D. C.; ZEE, Y. C. Veterinary microbiology. Malden: Blackwell Science, 1999. p. 192-195.

HODGES, R. T. Some observations on experimental Leptospira serotype Pomona infection in sheep. New Zealand Veterinary Journal, v. 22, n. 9, p. 151-154, 1974.

HOFF, E. F.; CARRUTHERS, V. B. Is Toxoplasma aggress the first step in invasion? Trends in Parasitology, v.18, n. 6, p. 251-255, 2002.

HOOKEY, J. V. Leptospira and leptospirosis. Journal of Biological Education, v. 25, p.169-172, 1991.

HOLT, J. G.; KRIEG, N. R.; SNEATH, P. H. A.; STALEY, J. T.; WILLIANS, S. T. Bergey's manual of determinative bacteriology. 9. ed. Baltimore: Williams \& Wilkins, 1994. 789 p.

HOMAN, W. L.; VERCAMMEN, M.; DE BRAEKELEER, J.; VERSCHUEREN, H. Identification of a 200- to 300-fold repetitive 529 bp DNA fragment in Toxoplasma gondii, and its use for diagnostic and quantitative PCR. International Journal for Parasitology, v. 30, n. 1, p. 69-75, 2000.

HOWE, L.; WEST, D. M.; COLLETT, M. G.; TATTERSFIELD, G.; PATTISON, R. S.; POMROY, W. E.; KENYON, P. R.; MORRIS, S. T.; WILLIAMSON, N. B. The role of Neospora caninum in three cases of unexplained ewe abortions in the southern North Island of New Zealand. Small Ruminant Research, v. 75, p. 115-122, 2008. 
HUGHES, K. L.; CLAXTON, P. D. Brucella ovis infection. 1. An evaluation of microbiological, serological and clinical methods of diagnosis in the ram. Australian Veterinary Journal, v. 44, p. 41-7, 1968.

HUM, S.; HORNITZKY, M.; BERG, T. Bovine Genital Campylobacteriosis, Australia and New Zealand Standard Diagnostic Procedures, novembro, 1-19, 2009.

INNES, E. A.; LUNDEN, A.; ESTEBAN, I.; MARKS, J.; MALEY, S.; WRIGHT, S.; RAE, A.; HARKINS, D.; VERMEULEN, A.; McKENDRICK, I. J.; BUXTON, D. A previous infection with Toxoplasma gondii does not protect against a challenge with Neospora caninum in pregnant sheep. Parasite Immunology, v. 23, p. 121-132, 2001.

JÁNOSI, K.; HAJTÓ, I.; MAKRAI, L.; GYURANECZ, M.; VARGA, J.; FODOR, L. First isolation of Histophilus somni from goats. Veterinary Microbiology, n. 133, p. 383386, 2009.

JANSEN, B. C. The aetiology of rams epididymitis. Onderstepoot Journal Veterinary Reseach, v. 47, p.101-107, 1980.

JANSEN, B. C. The epidimiology of bacterial infection of the genitalia in rams. Onderstepoot Journal Veterinary Reseach, v. 50, p.275-282, 1983.

JOLLEY, W. R.; McALLISTER, M. M.; McGUIRE, A. M.; WILLS, R. A. Repetitive abortion in Neospora-infected ewes. Veterinary Parasitology, v. 82, n. 3, p. 251257, 1999.

JONES, G. E. Mycoplasmas of sheep and goats: A synopsis. The Veterinary Record, v. 113, n. 24/31, p. 619-620, 1983.

JONES, K.; HOWARD, S.; WALLACE, J. S. Intermittent shedding of thermophilic campylobacters by sheep at pasture. Journal of Applied Microbiology, v. 86, p. 531-536, 1999.

LANGONI, H.; MARINHO, M.; BALDANI, S.; DA SILVA, A. V.; CABRAL, K. G.; DA SILVA, E. D. Pesquisa de aglutininas anti-leptospiras em soros ovinos do Estado de São Paulo, Brasil, utilizando provas de macroaglutinação em placa e soroaglutinação microscópica. Revista Brasileira de Medicina Veterinária, v. 17, n. 6, p. 264-268, 1995.

LARSSON, C. A.; JAMRA, L. M. F.; GUIMARÃES, E. C.; PATTOLI. B. G.; SILVA, H. L. L. Prevalência de toxoplasmose ovina determinada pela reação de SabinFeldman em animais de Uruguaiana, RS, Brasil. Revista de Saúde Pública, v. 14, n. 4, 1980.

LAW, L.; ELDER, J. K. Ovine epididymite-orchitis caused by Actinobacillus lignieresi. Australian Veterinary Journal, v. 45, n. 8, p. 240, 1969.

LEES, V. W.; YATES, W. D. G.; CORBEIL, L. B. Ovine Haemophilus somnus: experimental intracisternal infection and antigenic comparison with bovine 
Haemophilus somnus. The Canadian Journal of Veterinary Research, v. 58, p. 202-210, 1994.

LEON-VIZCAINO, L.; HERDOSO DE MENDOZA, M.; GARRIDO, F. Incidence of Abortions Caused by Leptospirosis in Sheep and Goats in Spain. Comparative Immunulogy Microbiology Infection Diseases, v. 10, n. 2, p. 149-153, 1987.

LEVETT, P. N. Leptospirosis. Clinical Microbiology Reviews, v. 14, p. 296-326, 2001.

LILENBAUM, W.; VARGES, R.; BRANDAO, F. Z.; CORTEZ, A.; SOUZA, S. O.; BRANDAO, P. E.;RICHTZENHAIN, L. J.; VASCONCELLOS, S. A. Detection of Leptospira spp. in semen and vaginal fluids of goats and sheep by polymerase chain reaction. Theriogenology, v. 69, p. 837-842, 2008.

LILENBAUM, W.; VARGES, R.; RISTOW, P.; CORTEZ, A.; SOUZA, S. O.; RICHTZENHAIN, L. J.; VASCONCELLOS, S. A. Identification of Leptospira spp. carriers among seroreactive goats and sheep by polymerase chain reaction.

Research in Veterinary Science, v. 87, n. 1, p. 16-19, 2009.

LIVINGSTON JUNIOR, C. W.; HARDY, W. T. Isolation of Actinobacillus seminis from ovine epididymitis. American of Journal Veterinary Research. v. 25, p. 660-663, 1964.

LIVINGSTON JUNIOR, C. W.; GAUER, B. B. Effect of venereal transmission of ovine ureaplasma on reproductive efficiency of ewes. American Journal Veterinary Research, v. 43, n. 7, p. 1190-1193, 1982.

LOPES, W. D. Z.; COSTA, A. J.; SOUZA, F. A.; RODRIGUES, J. D. F.; COSTA, G. H. N.; SOARES, V. E.; SILVA, G. S. Semen variables of sheep (Ovis aries) experimentally infected with Toxoplasma gondii. Animal Reproduction Science, v. 111, p. 312-319, 2009.

LOPES, W. D. Z.; SANTOS, T. R.; SILVA, R. S.; ROSSANESE, W. M.; SOUZA, F. A.; RODRIGUES, J. D. F.; MENDONÇA, R. P.; SOARES, V. E.; COSTA, A. J. Seroprevalence of and risk factors for Toxoplasma gondii in sheep raised in the Jaboticabal microregion, São Paulo State, Brazil. Research in Veterinary Science, v. 88, p. 104-106, 2010.

LOSTE, A.; RAMOS, J. J.; SÁEZ, T. Trastornos reproductivos ocasionados por carencias vitamínico minerales em ruminantes. Revista Albeitar, v. 48, p. 56-58, 2001.

LOW, J. C.; GRAHAM, M. M. Histophilus ovis epididymitis in a ram in the UK. The Veterinary Record, v. 117, p. 64-65, 1985.

LOW, J. C.; SOMERVILLE, D.; MYLNE, M. J.; McKELVEY, W. A. Prevalence of Actinobacillus seminis in the semen of rams in the United Kingdom. The Veterinary Record, v. 136, p. 268-269, 1995. 
LUNA-MARTÍNEZ, J. E.; MEJÍA-TERÁN, C. Brucellosis in Mexico: current status and trends. Veterinary Microbiology, v. 90, p.19-30, 2002.

LUNDEN, A.; NASHOLM, A.; UGGLA, A. Long-term study of Toxoplasma gondii infection in a Swedish sheep flock. Acta Veterinaria Scandinavica, v. 35, n. 3, p. 273-281, 1994.

LUNDERVOLD, M.; MILNER-GULLAND, E. J.; O'CALLAGHAN, C. J.; HAMBLIN,C.; CORTEYN, A.; MACMILLANS, A. P. A Serological Survey of Ruminant Livestock in Kazakhstan During Post-Soviet Transitions in Farming and Disease Control. Acta Veterinaria Scandinavica, v. 45, p. 211-224, 2004.

KAPOOR, S. G.; SINGH, P. P.; PATHAK, R. C. Prevalence of mycoplasma/acholeplasma in the genital tract of sheep. The Indian Journal Animal Sciences, v. 54, n. 7, p. 553-556, 1984.

KENNEDY, P. C.; BIBERSTEIN, E. L; HOWARTH, J. A.; FRAZIER, L. M.; DUNGWORTH, D. L. Infectious meningo-encephalitis in cattle, caused by a Haemophilus-like organism. American Journal of Veterinary Research, v. 21, p. 403-409, 1960.

KIDANEMARIAM, A.; GOUWS, J.; VAN VUUREN, M.; GUMMOW, B. Ulcerative balanitis and vulvitis of Dorper sheep in South Africa: a study on its aetiology and clinical features. Journal of the South African Veterinary Association, v. 76, n. 4, p. 197-203, 2005.

KIMBERLING, C. V.; ARNOLD, K. S.; SCHWEITER, D. J.; JONES, R. L.; VON BYERN, H.; LUCAS, M. Correlation of the presence of seminal white blood cells and the prevalence of separated spermatozoal heads with subclinical Brucella ovis infection in rams. Journal of the American Veterinary Medical Association, v. 189, n. 1, p. 73-76, 1986.

KIRKBRIDE, C. A. Diagnose in 1,784 ovine abortions and stillbirths. The Journal of Veterinary Diagnostic Investigation, n. 5, p. 398-402, 1993.

KIRKBRIDE C. A. ; JOHNSON, M. W. Serologic examination of aborted ovine and bovine fetal fluids for the diagnosis of border disease, bluetongue, bovine viral diarrhea, and leptospiral infections. The Journal of Veterinary Diagnostic Investigation, v. 1, n. 2, p. 132-138, 1989.

KOBAYASHI, Y.; YAMADA, M.; OMATA, Y.; KOYAMA, T.; SAITO, A.; MATSUDA, T.; OKUYAMA, K.; FUJIMOTO, S.; FURUOKA, H.; MATSUI, T. Naturally-occurring Neospora caninum infection in an adult sheep and her twin fetuses. The Journal of Pathology, v. 87, n. 2, p. 434-436, 2001.

KOTT, R. W.; HALVER, G. C.; FIREHAMMER, B.; THOMAS, V. M. Relationships between Brucella ovis semen culture and various semen and serology parameters. Theriogenology. v. 29, n. 4, p. 961-970, 1988. 
KOYAMA, T.; KOBAYASHI, Y.; OMATA, Y. YAMADA, M.; FURUOKA, H.; MAEDA, R.; MATSUI, T. SAITO, A.; MIKAMI, T. Isolation of Neospora caninum from the brain of a pregnant sheep. The Journal of Parasitology, v. 87, n. 6, p. 1486-1488, 2001.

KRAWCZYK, M. Serological evidence of leptospirosis in animals in northern Poland. The Veterinay Record, v.156, p. 88-89, 2005.

MAINAR, R. C.; DE LA CRUZ, C.; ASENSIO, A.; DOMINGUEZ, L.; VAZQUEZBOLAND, J. A. Prevalence of agglutinating antibodies to Toxoplasma gondii in small ruminants of the Madrid Region, Spain, and identification of factors influencing seropositivity by multivariate analysis. Veterinary Research Communications, v. 20, p. 153-159, 1996.

MAINAR; R. C.; VÁZQUEZ-BOLANDE, J. A. Associations of veterinary services and farmer characteristics with the prevalences of brucellosis and border disease in small ruminants in Spain. Preventive Veterinary Medicine, v. 40, p. 193-205, 1999.

MALIK, M. A.; DEESEN, D. W.; CRUZ, A. Toxoplasmosis in sheep in northastern United States. Journal of American Veterinary Medical Association, v. 196, n. 2, p. 263-265, 1990.

MANNERING, S. A.; WEST, D. M.; FENWICK, S. G.; MARCHANT, R. M.; O'CONNELL, K. Pulsed-field gel electrophoresis of Campylobacter jejuni sheep abortion isolates. Veterinary Microbiology, v. 115, p. 237-242, 2006.

MANNERING, S. A.; WEST, D. M.; FENWICK, S. G.; MARCHANT, R. M.; PERKINS, N. R., O'CONNELL, K. Pulsed-field gel electrophoresis typing of Campylobacter fetus subespécie fetus isolated from sheep abortions in New Zealand. New Zealand Veterinay Journal, v. 52, p. 358-363, 2004.

MARCA, M. C.; RAMOS, J. J.; LOSTE, A.; SAEZ, T.; SANZ, M. C. Comparison of indirect immunofluorescent antibody test and modified direct agglutination test methods for detection of Toxoplasma gondii antibodies in adult sheep in Spain. Veterinary Parasitology, v. 67, n. 1-2, p. 99-103, 1996.

MASALA, G.; PORCU, R.; DAGA, C.; DENTI, S.; CANU, G.; PATTA, C.; TOLA, S. Detection of pathogens in ovine and caprine abortion samples from Sardinia, Italy, by PCR. The Journal of Veterinary Diagnostic Investigation, v. 19, p. 96-98, 2007.

MASON, S.; QUINNELL, R. J.; SMITH, J. E. Detection of Toxoplasma gondii in lambs via PCR screening and serological follow-up. Veterinary Parasitology, v. 169, p. 258-263, 2010.

MAURIN, M. La brucellose à l'aube du $21^{\mathrm{e}}$ siècle. Médecine et Maladies Infectieuses, v. 35, p. 6-16, 2005.

MAVROGIANNI, V. S.; BROZOS, C. Reflections on the causes and the diagnosis of peri-parturient losses of ewes. Small Ruminant Research, v. 76, p. 77-82, 2008. 
MBAI, K.; MUNYUA, S. J. M.; GATHUMBI, P. K.; MBIUKI, S. M. Actinobacilus seminis as a cause of ram infertility in Kenya. Small Ruminant Research. v. 21, p. 227-231, 1996.

McALLISTER, M. M.; DUBEY, J. P.; LINDSAY, D. S.; JOLLEY, W. R.; WILLS, R. A.; McGUIRE, A. M. Dogs are definitive hosts of Neospora caninum. International Journal for Parasitology, v. 28, p.1473-1478, 1998.

McALLISTER, M. M.; McGUIRE, A. M.; JOLLEY, W. R.; LINDSAY, D. S.; TREES, A. J.; STOBART, R. H. Experimental neosporosis in pregnant ewes and their offspring. Veterinary Pathology, v. 33, n. 6, p. 647-655, 1996.

McCAUGHAN, C. J.; GORDON, L. M.; RAHALEY, R. S.; SLEE, K. J.; PRESIDENTE, P. J .A. Evidence for infection of sheep in victoria with leptospires of the hebdomadis serogroup. Australian Veterinary Journal, v. 56, p. 201, 1980.

McEVOY, T. G.; ROBINSON, J. J.; AITKEN, R. P.; FINDLAY, P. A.; ROBERTSON, I. $S$. Dietary excesses of urea influence the viability and metabolism of preimplantation sheep embryos and may affect fetal growth among survivors. Animal Reproduction Science, v. 47, p. 71-90, 1997.

McKEOWN, J. D.; ELLIS, W. A. Leptospira hardjo agalactia in sheep. The Veterinary Record, v. 118, n. 17, p. 482, 1986.

MELO, L. S. S.; CASTRO, M. B.; LEITE, R. C.; MOREIRA, E. C.; MELO, C. B. Principais aspectos da infecção por Leptospira sp em ovinos. Ciência Rural, v. 40, n. 5, p. 1235-1241, 2010.

MEIRELES, L. R.; GALISTEO JUNIOR; A. J.; ANDRADE JUNIOR, H. F. Serological survey of antibodies to Toxoplasma gondii in food animals from São Paulo state, Brazil. Brazilian Journal of Veterinary Research and Animal Science, v. 40, p. 267-271, 2003.

MILLAR, P. R.; SOBREIRO, L. G.; BONNA, I. C. F.; AMENDOEIRA, M. R. R. A. Importância dos animais de produção na infecção por Toxoplasma gondii no Brasil. Ciências Agrárias, v. 29, n.3, p. 693-706, 2008.

MILLER, R. B.; BARNUM, D. A.; McENTEE, K. E. Hemophilus somnus in the reproductive tracts of slaughtered cows: location and frequency of isolations and lesions. Veterinary Pathology, v. 20, p. 515-521, 1983.

MIRAGLIA, F.; MORAIS, Z. M.; CORTEZ, A.; MELVILLE, P. A.; MARVULLO, M. F. V.; RICHTZENHAIN, L. J.; VISINTIN, J. A.; VASCONCELLOS, S. A. Comparison of four antibiotics for inactivating leptospires in bull semen diluted in egg yolk extender and experimentally inoculated with Leptospira santarosai serovar guaricura.

Brazilian Journal of Microbiology, v. 34, p. 147-151, 2003.

MOORE, D. P. Neosporosis in South America. Veterinary Parasitology, v. 127, p. 87-97, 2005. 
MORAES, E. P. B. X.; BATISTA, A. M.; FARIA, E. B.; FREIRE, R. L.; FREITAS, A. C.; SILVA, M. A. R.; BRAGA, V. A.; MOTA, R. A. Experimental infection by

Toxoplasma gondii using contaminated semen containing different doses of tachyzoites in sheep. Veterinary Parasitology, v. 170, n. 3-4, p. 318-322, 2010.

MORENO, E. Brucellosis in Central America. Veterinary Microbiology, n. 90, p. 3138, 2002.

MOTIE, A.; MYERS, D. M. Leptospirosis in Sheep and Goats in Guyana. Tropical Animal Health and Production, v. 2, n. 18, p. 113-114, 1986.

MOTTA, A. C.; VIEIRA, M. I. B.; BONDAN, C.; EDELWEISS, M. I. A.; DAMETTO, M. A.; GOMES, A. Aborto em ovinos associado à toxoplasmose: caracterização sorológica, anátomo-patológica e imunoistoquímica. Revista Brasileira de Parasitologia Veterinária, v. 17, p. 209-214, 2008. Suplemento 1.

MOURA, A. B.; OSAKI, S. C.; ZULPO, D. L.; MARANA, E. R. M. Ocorrência de anticorpos contra Toxoplasma gondii em suínos e ovinos abatidos no município de Guarapuava, PR, Brasil. Revista Brasileira de Parasitologia Veterinária, v. 16, n. 1, p. 54-56, 2007.

NAREZ, G. M.; APARICIO, E. D.; MORALES-ALVAREZ, J. F.; ROMERO, F. A.; GUEMES, F. S. Ovine epididymitis: bacteriological and serological studies.

Veterinaria-Mexico, v. 30, p. 329-336, 1999.

NAVARRO, J. A.; ORTEGA, N.; BUENDIA, A. J.; GALLEGO, M. C.; MARTINEZ, C. M.; CARO, M. R.; SANCHEZ, J.; SALINAS, J. Diagnosis of placental pathogens in small ruminants by immunohistochemistry and PCR on paraffin-embedded samples. The Veterinary Record, v. 165, n. 6, p.175-178, 2009.

NETER, J.; KUTNER, M. H.; NACHTSHEIM, C. J.; WASSERMAN, W. Applied linear statistical models. 4. ed. Boston: Mc Graw Hill, 1996.

NICHOLAS, R. A. J.; WESSELS, M.; ORME, P. K.; WOOD, E.; SACHSE, K. Isolation of Mycoplasma ovine/caprine serogroup 11 from infertile sheep in Britain. The Veterinary Record, v. 145, n. 9, p. 434-435, 1999.

NOZAKI, C. N.; MEGID, K. C.; SILVA JUNIOR, F. F.; VELOSO, C. S. Comparação das técnicas de imunodifusão em gel de ágar e ELISA no diagnóstico de bucelose ovina em cabanhas da região Centro-Oeste do Estado de São Paulo. Arquivo do Instituto Biológico, v. 71, n. 1, p. 1-5, 2004.

OIE. ORGANIZAÇÃO INTERNACIONAL DE EPIZOOTIAS. Campylobacteriosis. 2005. p. 1-5, 2005. Institute for International Cooperative in Animal Biologics. The Center for Food Security \& Public Health - lowa State University, College of Veterinary Medicine lowa State University.

OIE. ORGANIZAÇÃO INTERNACIONAL DE EPIZOOTIAS. Epididimitis ovina (Brucella ovis). 2006. Art. 2.3.1.1. Pt. 2, sect. 2.4, cap.2.4.1. Disponivel em: <http://www.oie.int.htm>. Acesso em: 17 jul. 2010. 
OCHOLI, R. A.; KWAGA, J. K. P.; AJOGI, I.; BALE, J. O. O. Phenotypic characterization of Brucella strains isolated from livestock in Nigeria. Veterinary Microbiology, v. 103, p. 47-53, 2004.

OCHOLI, R. A.; KWAGA, J. K. P.; AJOGI, I.; BALE, J. O. O. Abortion due to Brucella abortus in sheep in Nigeria. Revue Scientifique et Technique, v. 24, n. 3, p. 973979, 2005.

ØYSTEIN, A.; AHRENS, P.; TEGTMEIER, C. Development of a PCR test for identification of Haemophilus somnus in pure and mixed cultures. Veterinary Microbiology, v. 63, p. 39-48,1998.

OGAWA, L.; NAVARRO, I. T.; FREIRE, R. L.; OLIVEIRA, R. C.; VIDOTTO, O. Ocorrência de anticorpos anti-Toxoplasma gondii em ovinos da região de Londrina no Estado do Paraná. Ciência Rural, v. 24, n. 1, p. 57-62, 2003.

OLIVEIRA, C. A. M.; FIGUEIREDO, C. L.; BERNARDELLI, D. C. G.; CELEGHINI, E. C. C.; TOCHIO, F. V.; NAVAR, L. Avaliação andrológica em ovinos da raça Texel em diferentes idades. In: CONGRESSO INTERNCIONAL FEINCO, 5., 2010, São Paulo, SP. Anais... 2010. CD-ROOM.

OLIVEIRA-SIQUEIRA, T. C. G.; AMARANTE, A. F. T.; SALATA, E.; SOGAYAR, R. Serological survey for Toxoplasma gondii infection in sheep in São Paulo states, Brazil. Veterinária e Zootecnia, v. 5, p. 121-125, 1993.

OKUDA, L. H.; SILVA, G. J; VILLALOBOS, E. M. C.; DEL FAVA, C.; CUNHA, E. M. S.; LARA, M. C. C. S. H.; DE STEFANO, E.; PITUCO, E. M. toxoplasmose em um rebanho ovino (Ovis áries) no Estado de Minas Gerais, Brasil. In: ENCONTRO NACIONAL DE PATOLOGIA VETERINÁRIA, 13., Campo Grande, MS, 2007. Anais... 2007.

OPORTO, B.; ESTEBAN, J. I.; ADURIZ, G.; JUSTE, R. A.; HURTADO, A. Prevalence and strain diversity of thermophilic campylobacters in cattle, sheep and swine farms. Journal of Applied Microbiology, v. 103, n. 4, p. 977-984, 2007.

OTERO, A. R. S.; UZÊDA, R. S.; JESUS, E. E. V.; PINHEIRO, A. M.; ALMEIDA, M. A. O. Ocorrência de anticorpos IgG anti-Neospora caninum em rebanho de ovinos no Estado da Bahia. In: FÓRUM BRASILEIRO DE ESTUDOS SOBRE NEOSPORA CANINUM, 1., 2005, São Paulo-SP. Anais... São Paulo: Colégio Brasileiro de Parasitologia Veterinária, 2005.

OTTER, A.; WILSON, B. W.; SCHOLES, S. F. E.; JEFFREY, M.; HELMICK, B.; TREES, A. J. Results of a survey to determine whether Neospora is a significant cause of ovine abortion in England and Wales. The Veterinary Record, v. 140, n.15, p. 175-177, 1997.

OWEN, M. R.; CLARKSON, M. J.; TREES, A. J. Acute phase toxoplasma abortions in sheep. The Veterinary Record, v. 142, n. 18, p. 480-482, 1998. 
OZDEMIR, E.; EROL, V. Leptospirosis in Turkey. The Veterinary Record, v. 150, p. 248-249, 2002.

PALFI, V.; GLAVITIS, R.; HAJTÓS, I. Testicular lesions in rams infected by maedi/visna vírus. Acta Veterinaria Hungarica, v. 37, n. 1-2, p. 97-102, 1989.

PANDERO, R.; PAINCEIRA, A.; LÓPEZ, C.; VÁZQUEZ, L.; PAZ, A.; DÍAZ, P.; DACAL, V.; CIENFUEGOS, S.; FERNÁNDEZ, G.; LAGO, N.; DÍEZ-BAÑOS, P.; MORRONDO, P. Seroprevalence of Toxoplasma gondii and Neospora caninum in wild and domestic ruminants sharing pastures in Galicia (Northwest Spain).

Research in Veterinary Science, v. 88, p. 111-115, 2010.

PANTER, K.; JAMES, L. F.; HARTLEY, W. J. Transients testicular degeneration in rams fed locowed (Astragalus lentiginosus). Veterinary and Human Toxicology, v. 31, n. 1, p. 41-46, 1989

PAOLICCHI, F. A.; CASARO, P. A.; GIMENO, E. J.; KORTEBANI, L. G.; MAZZOLLI, A. B. Antisperm response in rams experimentally infected with Brucella ovis. Small Ruminant Research, v. 36, p. 7-15, 2000.

PARÉ, J.; HIETALA, S. K.; THURMOND, M. C. Interpretation of an indirect fluorescent antibody test for diagnosis of Neospora sp. infection in cattle. The Journal of Veterinary Diagnostic Investigation, v. 7, n. 2, p. 273-275, 1995.

PASTOR, L. M. G. Auteraciones testiculares en muruecos: estudio clinico, serologico, microbiologico y anatomopatológico. 2006. 166 p. Tese (Dotorado em Patologia Animal) - Faculdade de Veterinaria, Universidade de Zaragoza, Zaragoza, 2006.

PAULINO, C. D.; SINGER, J. Análise de dados categorizados. São Paulo: Edgard Blucher, 2006.

PENA, H. F. J.; SOARES, R. M.; RAGOZO, A. M. A.; MONTEIRO, R. M.; YAI, L. E. O.; NISHI, S. M.; GENNARI, S. M. Isolation and molecular detection of Neospora caninum from naturally infected sheep from Brazil. Veterinary Parasitology, v. 147, p. 61-66, 2007.

PENNER, J. L. The genus Campylobacter: a decade of progress. Clinical Microbiology Reviews, v. 1, n. 2, p. 157-172, 1988.

PEREIRA-BUENO, J.; QUINTANILLA, A.; PÉREZ-PÉREZ, V.; ÁlVAREZ-GARCÍA, G.; COLLANTES-FERNÁNDEZ, E.; ORTEGA-MORA, L. M. Evaluation of ovine abortion associated with Toxoplasma gondii in Spain by different diagnostic techniques. Veterinary Parasitology, v. 121, p. 33-43, 2004.

PESCADOR, C. A.; CORBELLINI, L. G.; OLIVEIRA, E. C.; BANDARRA, P. M.; LEAL, J. S.; PEDROSO, P. M. O.; DRIEMEIER, D. Aborto ovino associado com infecção por Sarcocystis sp. Pesquisa Veteterinaria Brasileira, v. 27, n. 10, p.393397, 2007. 
PINHEIRO JUNIOR, J. W.; MOTA, R. A.; OLIVEIRA, A. A. F.; FARIA, E. B.; PITA GONDIM, L. F.; SILVA, A. V.; ANDERLINI, G. A. Prevalence and risk factors associated to infection by Toxoplasma gondii in ovine in the State of Alagoas, Brazil. Parasitology Research, v. 105, p. 709-715, 2009.

PINHEIRO JÚNIOR, J. W.; MOTA, R. A.; PIATTI, R. M.; OLIVEIRA, A. A. F.; DA SILVA, A. M.; ABREU, S. R. O.; ANDERLINI, G. A.; VALENÇA, R. M. B.

Seroprevalence of antibodies to Chlamydophila abortus in ovine in the State of Alagoas, Brazil. Brazilian Journal Microbiology, v. 41, n. 2, p. 358-364 , 2010.

PINHEIRO JUNIOR, J. W.; SOUZA, M. M. A.; GUERRA, N. R.; SANTANA, V. L. A.; MOTA, R. A. Freqüência de aglutininas anti-brucella abortus em caprinos e ovinos do sertão do estado de Pernambuco, Brasil. Ciência Animal Brasileira, v. 9, n. 4, p. 1096-1101, 2008.

PITA GONDIM, L. F.; BARBOSA, H. V.; RIBEIRO FILHO, C. H. A.; SAE, H. Serological survey of antibodies to Toxoplasma gondii in goats, sheep, cattle and water buffaloes en Bahia State, Brasil. Veterinary Parasitogy, v. 82, p. 273-276, 1999.

POESTER, F. P.; GONÇALVES, V. S. P.; LAGE, A. P. Brucellosis in Brazil. Veterinary Microbiology, v. 90, p. 55-62, 2002.

PNSCA. Programa Nacional de Sanidade de Caprinos e Ovinos - PNSCO. [s.d.]. Disponível em: <http://www.agricultura.gov.br/portal/page/portal//nternetMAPA/pagina-inicial/animal/sanidade-animal>. Acesso em: 17 jan. 2011.

PUENTE-REDONDO, D. A.; GARCÍA DEL BLANCO, N.; PÉREZ-MARTÍNEZ, C.; GONZÁLEZ-RODRÍGUEZ, M. C.; RODRÍGUEZ-FERRI, E. F.; GUTIÉRREZMARTÍN, C. B. Isolation of Actinobacillus seminis from the Genital Tract of Rams in Spain. Journal of Comparative Pathology, v. 122, p. 217-222, 2000.

QUINLIVAN, T. D.; JOOP, A. J. A survey on the incidence and cause of ovine abortion in Hawkes Bay. New Zealand Veterinary Journal, v. 30, p. 65-68, 1982.

QUINN, P. J.; MARKEY, B. K.; CARTER, M. E.; DONNELLY, W. J.; LEONARD, F. C. Microbiologia Veterinária e doenças infecciosas. 2. ed. Porto Alegre: Artmed, 2005. p.172-174.

QUISPE, C. H. R.; RIVERA, G. H.; ROSADIO, A. R. Cinética de la infección por Brucella ovis en carneros durante una época de empadre. Revista de

Investigaciones Veterinarias del Perú, v. 13, n. 1, p. 61-66, 2002.

RAFYI, A.; MAGHAMI, G.; NIAK, A. I. Leptospirose ovine et caprine. Bulletin de l'Office International des Epizooties, v. 68, p. 43-59, 1967.

RAHALEY, R. S.; EDWARDS, L. D. Histophilus ovis. The Canadian Veterinary Journal, v. 24, n. 2, p. 61-62, 1983. 
RAHALEY, R. S.; WHITE, W. E. Histophilus ovis infection in sheep in Western Victoria. Australian Veterinary Journal, v. 53, p. 124-127, 1977.

RAJI, M. A.; ADEKEYE, J. O.; KWAGA, J. K. P.; BALE, J. O. O. Bioserogroups of Campylobacter species isolated from sheep in Kaduna State, Nigeria. Small Ruminant Research, v. 37, p. 215-221, 2000.

RAMOS, A. A.; MIES FILHOS, A.; SCHENCK, J. A. P.; VASCONCELLOS, L. D.; PRADO, O. T. G.; FERNANDES, J. C. T.; BLOBEL, H. Epididimite ovina, levantamento clínico no Rio Grande do Sul. Pesquisa Agropecuária Brasileira, v. 1, p. 211-213, 1966.

REVIRIEGO, F. J.; MORENO, M. A.; DOMÍNGUEZ, L. Risk factors for brucellosis seroprevalence of sheep and goat flocks in Spain. Preventive Veterinary Medicine, v. 44 , p. $167-173,2000$.

RHODES, A. P. The effect of extensive chorioptic mange of the scrotum on reproductive function of the ram. The Australian Veterinary Journal, v. 52, n. 6, p. 250-257, 1976.

RHYAN, J. C.; DUBEY, J. P. Ovine abortion and neonatal death due to toxoplasmosis in Montana. Journal of American Veterinary Medical Association, v. 184, n. 6, p. 661-664, 1984.

RICHTZENHAIN, L. J.; CORTEZ, A.; HEINEMANN, M. B.; SOARES, M.; SAKAMOTO, S. M.; VASCONCELLOS, S. A.; HIGA, Z. M. M.; SCARCELLI, E.; GENOVEZ, M. E. A multiplex PCR for the detection of Brucella spp. and Leptospira spp. DNA from aborted bovine fetuses. Veterinary Microbiology, v. 87, p. 139 - 147, 2002.

RIDLER, A. L. An overview of Brucella ovis infection in New Zealand. New Zealand Veterinary Journal, v. 50, n. 3, p. 96-98, 2002.

RIS, D. R. The bacteriology and serology of ewes inoculated with viaible Brucella ovis organisms. New Zealand Veterinary Journal, v. 18, p. 2-7, 1970.

RIZZO, H. Avaliação clínica e estudo da ocorrência de fêmeas ovinas infectadas por micoplasmas na região de Piedade - SP - "Avaliação da infecção sobre a produtividade do rebanho". 2006. 110 p. Dissertação (Mestrado em Clínica Veterinária) - Faculdade de Medicina Veterinária e Zootecnia, Universidade de São Paulo, São Paulo, 2006.

RIZZO, H.; GREGORY, L.; MEIRA JR., E. B. S.; PIVA, F. M.; MATTOS, A. C. D.; LOBATTO, Z.; HASEGAWA, M. Y. Incidência de Língua Azul em ovinos do estado de São Paulo com histórico de problemas reprodutivos. In: CONGRESSO INTERNCIONAL FEINCO, 5., 2010, São Paulo, SP. Anais... 2010. Disponível em: $<$ http://www.feinco.com.br/downloads congresso/1268142946 538.pdf>. Acesso em: 3 jan. 2011. 
ROBERTS, D. S. A new pathogen from a ewe with mastitis. Australian Veterinary Journal, v. 32, p. 330-332, 1956.

ROBLES, C. A. Epididimitis contagiosa de los carneros por Brucella ovis. Revista de Medicina Veterinaria, v. 79, n. 1, p. 67-71, 1998.

ROBLES, C. A. Brucelosis de Los Carneros. Revista IDIA XXI, n. 7, p. 83-86, 2004.

ROBLES, C. A.; URCULLU, J. A.; UZAL, F. A.; MERIO, R. Primer diagnostico em Patagonia de orchideoepididimitis em carneros por bacilos pleomorficos Gram negativos. Veterinaria Argentina, v. 7, p. 453-455, 1990.

ROBLES, C. A.; UZAL, F. A.; OLAECHEA, F. V.; LOW, C. Epidemiological observations in a corriedale flock affected by Brucella ovis. Veterinary Research Communications, v. 22, p. $435-443,1998$.

ROMANELLI, P. R.; FREIRE, R. L.; VIDOTTO, O.; MARANA, E. R. M.; OGAWA, L.; DE PAULA, V. S. O.; GARCIA, J. L.; NAVARRO, I. T. Prevalence of Neospora caninum and Toxoplasma gondii in sheep and dogs from Guarapuava farms, Paraná State, Brazil. Research in Veterinary Science, v. 82, n. 2, p. 202-207, 2007.

ROSENBERGER, G. Enfermedades de los bovinos. Montevideo: Hemisferio Sur, 1983. Tomo 2, $577 \mathrm{p}$.

ROSSI, G. F.; CABRAL, D. D.; CORRÊA, R. R. Soroprevalência de Toxoplasma gondii em ovinos no município de Uberlândia- MG. In: CONGRESSO BRASILEIRO DE MEDICINA VETERINÁRIA, 35., 2008, Gramado, RS. Anais... 2008. Disponível em: <http://www.sovergs.com.br/conbravet2008/anais/cd/resumos/R0553-2.pdf>. Acesso em: 3 jan. 2011.

ROSSI, G. F.; CABRAL, D. D.; SILVA, D. A. O.; RIBEIRO, D. P.; PAJUABA, A. C. A. M.; MOREIRA, R. Q.; CORREA, R. R. Frequência de anticorpos contra Toxoplasma gondii e Neospora caninum em ovinos do município de Uberlândia-MG. In:

CONGRESSO BRASILEIRO DE MEDICINA VETERINÁRIA, 35., 2008, Gramado, RS. Anais... 2008. Disponível em:

http://www.sovergs.com.br/conbravet2008/anais/cd/resumos/R0553-1.pdf>. Acesso em: 3 jan. 2011.

SAGLAM, Y. S. ; YENER, Z.; TEMUR, A.; YALCIN, E. Immunohistochemical detection of leptospiral antigens in cases of naturally occurring abortions in sheep.

Small Ruminant Research, v. 74, p. 119-122, 2008.

SAHIN, O.; PLUMMER, P. J.; JORDAN, D. M.; SULAJ, K.; PEREIRA, S.; ROBBEAUSTERMAN, S.; WANG, L.; ZHANG, Q. Emergence of a Tetracycline-Resistant Campylobacter jejuni Clone Associated with Outbreaks of Ovine Abortion in the United States. Journal of Clinical Microbiology, v. 46, n. 5, p. 1663-1671, 2008.

SANTA ROSA, C. A.; CASTRO, A. F. P. Presença de aglutininas antileptospiras em soro de ovinos e caprinos no Estado de São Paulo. Arquivos Instituto de Biologia, v. 30, p. $93-98,1963$. 
SANTA ROSA, C. A.; CASTRO, A. F. P.; SILVA, A. S.; TERUYA, J. M. Nove anos de leptospirose no Instituto Biologico de SP. Revista do Instituto Adolfo Lutz, v. 2930, p. 19-27, 1969/1970.

SANTANA, A. F.; COSTA, G. B.; FONSECA, L. S. Avaliação da circunferência escrotal como critério de seleção de machos jovens da raça Santa Inês. Revista Brasileira de Saúde e Produção Animal, v. 1, p. 27-30, 2001.

SAUNDERS, V. F.; REDDACLIFF, L. A.; BERG, T.; HORNITZKY, M. Multiplex PCR for the detection of Brucella ovis, Actinobacillus seminis and Histophilus somni in ram semen. Australian Veterinary Journal, v. 85, n. 1/2, p. 72-77, 2007.

SCARCELLI, E.; GENOVEZ, M. E.; CARDOSO, M. V.; SOUZA, M. C. A. M.; GRASSO, L. M. P. S.; SOUZA, C. A. I.; TORRES, A. P. Avaliação do Potencial de Disseminação de Campylobacter spp por diferentes espécies animais. Arquivo do Instituto Biológico, v. 65, n. 1, p. 55-61, 1998.

SCARCELLI, E.; PIATTI, R. M.; CARDOSO, M. V.; MIYASHIRO, S.; CAMPOS, F. R.; TEIXEIRA, S.; CASTRO, V.; GENOVEZ, M. E. Detecção de agentes bacterianos pelas técnicas de isolamento e identificação e PCR - Multiplex em fetos bovinos abortados. Revista Brasileira de Reprodução Animal, v. 28, n. 1, p. 23-27, 2004.

SCHMITZ, J. A. ; COLES, B. M.; SHIRES, G. M. Fatal hemolytic disease in sheep attributed to Leptospira interrogans serotype hardjo infection. Cornell Veterinary Medicine, v. 71, n. 2, p. 175-182, 1981.

SCHREINER, E.; GOMES, M. J. P.; CARDOSO, M. I.; FERNANDES, J. C. T.; HOPE, L. P.; LAITANO, J. L. L.; FERNANDES, R. E. Epididimite ovina: Isolamento de Actinobacillus seminis em Central de Inseminação artificial no Rio Grande do Sul In: CONGRESSO ESTADUAL DE MEDICINA VETERINARIA, 11., 1992. Gramado, RS. Anais... 1992 p. 96.

SERGEANT, E. S. G. Seroprevalence of Brucella ovis infection in commercial ram flocks in the Tamworth area. New Zealand Veterinary Journal, v. 42, n. 3, p. 97100, 1994.

SHAREEF, J. M. A Review of Serological Investigations of Brucellosis Among Farm Animals and Humans in Northern Provinces of Iraq (1974-2004). Journal of Veterinary Medicine, v. 53, p. 38-40, 2006.

SILVA, A. V.; CUNHA, E. L. P.; MEIRELES, L. R.; GOTTSCHALK, S.; MOTA, R. A.; LANGONI, H. Toxoplasmose em ovinos e caprinos: estudo soroepidemiológico de duas Regiões do Estado de Pernambuco, Brasil. Ciência Rural, v. 33, n. 1, p. 115119, 2003.

SILVA, E. F.; BROD, C. F.; CERQUEIRA, G. M.; BOURSCHEIDT, D.; SEYFFERT, N.; QUEIROZ, A.; SANTOS, C. S.; KO, A.; DELLAGOSTIN, O. A. Isolation of Leptospira noguchii from sheep. Veterinary Microbiology, v. 31, p. 144-149, 2007. 
SILVA, K. L. M. V.; DE LA RUE, M. L. Possibilidade da transmissão congênita de Toxoplasma gondii em ovinos através de seguimento sorológico no município de Rosário do Sul, RS, Brasil. Ciência Rural, v. 36, n. 3, p. 892-897, 2006.

SIMMONS, G. C.; BAYNES, I. D.; LUDFORD, C. G. Epidemiology of Actinobacillus seminis in a flock of Border Leicester sheep, Australian Veterinary Journal, v. 42, p. 183-187, 1966.

SMITH, B. P.; ARMSTRONG, J. M. Fatal hemolytic anemia attributed to Leptospirosis in lambs. Journal of the American Veterinary Medical Association, v. 167, n. 8, p. 739-741, 1975.

SMITH, I. D.; HUGHES, K. L. Progesterone concentrations in the peripheral plasma of pregnant ewes following infection with an abortifacient organism. Research in Veterinary Science, v. 8, p. 116-118, 1974.

SMITH, R. E.; HENCH, E. C.; REYNOLDS, I. M. Experimental leptospirosis in pregnant ewes. VI. Immunofluorescence in the diagnosis of fetal leptospirosis. Cornell Veterinary Medicine, v. 56, n. 4, p. 640-647, 1966.

SMITH, R. E.; REYNOLDS, I. M.; CLARK, G. W. Experimental leptospirosis in pregnant ewes. IV. Intravenous and intrafetal inoculations. Cornell Veterinary Medicine, v. 52, p. 99-109, 1962.

SMITH, R. E.; REYNOLDS, I. M.; CLARK, G. W. Experimental leptospirosis in rams. Cornell Veterinary Medicine, v. 55, p. 412-419, 1965.

SMITH, R. E.; REYNOLDS, I. M.; CLARK, G. W. Experimental leptospirosis in pregnant ewes. V. Middle uterine artery inoculations. Cornell Veterinary Medicine, v. 56, n. 3, p. 418-426, 1966.

SMITH, R. E.; REYNOLDS, I. M.; SATAKI, T. Experimental leptospirosis in pregnant ewes. I. Clinical, bacteriological and serological features. Cornell Veterinary Medicine, v. 50, p. 34-46, 1960a

SMITH, R. E.; REYNOLDS, I. M.; SATAKI, T. Experimental leptospirosis in pregnant ewes. III. Pathological features. Cornell Veterinary Medicine, v. 50, p. 115-122, 1960b.

SOARES, H. S.; AHID, S. M.; BEZERRA, A. C.; PENA, H. F.; DIAS, R. A.; GENNARI, S. M. Prevalence of anti-Toxoplasma gondii and anti-Neospora caninum antibodies in sheep from Mossoró, Rio Grande do Norte, Brazil.

Veterinary Parasitology, v. 160, n. 3-4, p. 211-214, 2009.

SOUZA NETO, O. L.; ALBUQUERQUE, P. P. F.; SANTOS, A. S.; FERNANDES, F. T. S.; FARIAS, E. B.; MORAES, E. P. B. X.; RABELO, S. S. A.; DA SILVA, L. B. G.; MOTA, R. A. Prevalência de anticorpos IgG anti-Neospora caninum e fatores de risco associados à infecção em ovinos no município de Gravatá, Pernambuco,Brasil. In: JORNADA DE ENSINO, PESQUISA E EXTENSAO - JEPEX, 9., 2009, Recife.

Anais... 2009. Disponível em: 
$<$ http://www.eventosufrpe.com.br/jepex2009/cd/resumos/R1003-1.pdf >. Acesso em: 3 jan. 2011.

ṠPILOVSKÁ, S. S.; REITEROVÁ, K.; KOVÁCOVÁ, D.; BOBÁKOVÁ, M.; DUBINSKY, $P$. The first finding of Neospora caninum and the occurrence of other abortifacient agents in sheep in Slovakia. Veterinary Parasitology, v. 164, p. 320-323, 2009.

SPONENBERG, D. P.; CARTER, M. E.; CARTER, G. R.; CORDES, D. O.; STEVENS, S. E.; VEIT, H. P. Suppurative epididymitis in a ram infected with Actinobacillus seminis. Journal of the American Veterinary Medical Association, v. 182, n, 9, p. 990-991, 1983.

SPÓSITO FILHA, E.; AMARAL, V.; MACRUZ, R.; REBOUÇAS, M. M.; SANTOS, S. M.; DRUMOND, L. S. Toxoplasma gondii em ovinos: isolamento do parasita a partir de diafragmas procedentes de animais do estado de Rio Grande do Sul e abatidos em matadouros de São Paulo, para o consumo humano. Revista Brasileira de Parasitologia Veterinária, v. 1, n. 2, p. 117-119, 1992.

SPROSTON, E. L.; OGDEN, I. D.; MAC RAE, M.; FORBES, K. J.; DALLAS, J. F.; SHEPPARD, S. K.; CODY, A.; COLLES, F.; WILSON, M. J.; STRACHAN, N. J. C. Multi-locus sequence types of Campylobacter carried by flies and slugs acquired from local ruminant faeces. Journal of Applied Microbiology, v. 109, n. 3, p. 829838, 2010.

STANLEY, K.; JONES, K. Cattle and sheep farms as reservoirs of Campylobacter. Journal of Applied Microbiology, v. 94, p. 104-113, 2003.

STANLEY, K. N.; WALLACE, J. S.; CURRIE, J. E.; DIGGLE, P. J.; JONES,K. Seasonal variation of thermophilic campylobacters in lambs at slaughter. Journal of Applied Microbiology, v. 84, p. 1111-1116, 1998.

STANSFIELD, D. G.; HUNT, B.; KEMBLE, P. R. Campylobacter gastroenteritis in fattening lambs. The Veterinary Record, v. 118, n. 22, p. 210-211, 1986.

SULLIVAN, N. D. Leptospirosis in animals and man. Australian Veterinary Journal, v. 50 , n. 5 , p.216 - 223, 1974.

SWIFT, B. L.; CRADDOCK, F.; HANCOCK, H. A.; JENSEN, R.; THOMAS, G. M.; TRUEBLOOD, M. S.; WEIBEL, J. Ram epididymitis: A clinical report.

Theriogenology, v. 17, n. 3, p. 343-347, 1982.

TENTER, A. M.; HECKEROTH, A. R.; WEISS, L. M. Toxoplasma gondii: from animals to humans. International Journal for Parasitology, v. 30, p.1217-1258, 2000.

THOMAZ-SOCCOL, V.; CASTRO, E. A.; GAZDA, T. L.; GARCIA, G.; ROSARIA, R. T. B. R.; DITTRICH, R. L. Ocorrência de anticorpos anti-Toxoplasma gondii em ovinos das áreas urbanas e periurbanas de Curitiba, Paraná. Revista Brasileira de Parasitologia Veterinária, v. 18, p. 69-70, 2009. Suplemento 1. 
UENO, T. E. H. Soroprevalência de Brucella ovis em ovinos do noroeste paulista, Brasil. In: CONGRESSO INTERNCIONAL FEINCO, 5., 2010, São Paulo, SP.

Anais... 2010. Disponível em:

$<$ http://www.feinco.com.br/downloads congresso/1268142579 435.pdf >. Acesso em: 3 jan. 2011.

UENO, T. E. H.; GONÇALVES, V. S. P.; HEINEMANN, M. B.; DILLI, T. L. B.; AKIMOTO, B. M.; SOUZA, S. L. P.; GENNARI, S. M.; SOARES, R. M. Prevalence of Toxoplasma gondii and Neospora caninum infections in sheep from Federal District, central region of Brazil. Tropical Animal Health and Production, v. 41, p. 547-552, 2009.

VAN DREUMEL, A. A.; KIERSTEAD, M. Abortion associated with Haemophilus somnus infection in a bovine fetus. The Canadian Veterinary Journal, v. 16, p. 367-370, 1975.

VARGAS, A. C.; CECIM, M.; VIANA, L. R.; SPRIACIGO, D. A.; COSTA, M. M. Isolamento de Campylobacter jejuni em feto ovino abortado: relato de caso. Arquivo Brasileiro Medicina Veterinária e Zootecnia, v. 57, n. 3, p. 317-320, 2005.

VAUGHAN, L. Abortion in sheep. The Compedium on Continuing Education for the Practicing Veterinarian, v. 49, n. 3, p. 170-174, 1996.

VIEGAS, E. A.; VIEGAS, S. R. A.; CALDAS, E. M. Aglutininas anti-Leptospira em hemosoro de caprinos e ovinos, no Estado da Bahia. Arquivos da Escola de Veterinária da Universidade Federal da Bahia, v. 5, n. 1, p. 20-34, 1980.

VIEGAS, E. A.; YANAGUITA, R. M.; VIEGAS, S. A. R. A.; SILVA, L. A.; VASCONCELLOS, S. A. Emprego de estirpes de Leptospira biflexa na prova de soroaglutinação microscópica aplicada ao diagnóstico da leptospirose caprina e ovina. Brazilian Journal Veterinary Animal Science, v. 31, n. 1, p. 25-30, 1994.

VOGEL, F. S. F.; ARENHART, S.; BAUERMANN, F. V. Anticorpos anti-Neospora caninum em bovinos, ovinos e bubalinos no Estado do Rio Grande do Sul. Ciência Rural, v. 36, n. 6, p. 1948-1951, 2006.

WALKER, R. L.; BIBERSTEIN, R. F.; PRITCHETT, R. F.; KIRKHAN, C. Deoxyribonucleic Acid Relatedness Among "Haemophilus agni", "Histophilus ovis", "Actinobacillus seminis", and "Haemophilus influenae". International Journal of Systematic Bacteriology, v. 35, n. 1, p. 46-49, 1985.

WALKER, R. L.; LEAMASTER, B. R. Prevalence of Histophilus ovis and Actinobacillus seminis in the genital tract of sheep. American Journal of Veterinary Research, v. 47, p. 1928-1930, 1986.

WALT, M. L. Campylobacter jejuni infection. In: COETZER, J. A. W.; THOMSON, G. R.; TUSTIN, R. C. Infectious diseases of livestock with special reference to Southern Africa. United Kingdom: Oxford, 1994. P. 1025-1029. 
WALTNER-TOEWS, D.; MONDESIRE, R.; MENZIES, P. The seroprevalence of Toxoplasma gondii in Ontario sheep flocks. Canadian Veterinary Journal, v. 32, p. 734-737, 1991.

WATT, D. A.; BAMFORD, V.; NAIRN, M. E. Actinobacillus seminis as a cause of polyarthitis and posthitis in sheep. Australian Veterinary Journal, v. 46, p 515, 1970.

WATSON, W. A. Abortion and stillbirth in sheep. The Veterinary Bulletin, v. 32, p. 259-264, 1962.

WEST, D. M.; POMROY, W. E. ; COLLETT, M. G.; HILL, F. I.; RIDLER, A. L.; KENYON, P. R.; MORRIS, S. T.; PATTISON, R. S. A possible role for Neospora caninum in ovine abortion in New Zealand. Small Ruminant Research, v. 62, n. 12, p. 135-138, 2006.

WET, J. A. L.; ERASMUS, J. A. Epididymitis of rams in the central and southern districts of the Orange Free State. Journal of the South African Veterinary Association, v. 55, n. 4, p. 173, 176-179, 1984.

WIEMER, K. E.; RUTTLE, J. L. Semen characteristics, scrotal circumference and bacterial isolates of fine wool range rams. Theriogenology ${ }_{2}$ v. 28, n. 5, p. 625-637, 1987.

WINTER, A. G. L. hardjo and lambs receiving cow's colostrum. The Veterinay Record, v. 124, n. 19, p. 520, 1989.

WOLFE, D. F.; STRINGFELLOW, L. D. A.; RIDDELL, M. G.; LAUERMAN, H.; GALIK, P. K. Adherence of Brucella ovis to preimplantation ovina ova.

Theriogenology, v. 30, n. 2, p. 387-393, 1988.

WOODS, L. W.; ANDERSON, M .L. Scoliosis and hydrocephalus in an ovine fetus infected with Toxoplasma gondii. Journal of Veterinary Diagnostic Investigation, v. 4, n. 2, p. 220-222, 1992.

WORLD ORGANIZATION FOR ANIMAL HEALTH. Manual of Standarts for Diagnostic tests and Vaccines. Paris: OIE, 2004. p. 1072 -1081.

WORTHINGTON, R. W.; BOSMAN, P. P. Isolation of Actinobacillus seminis in South Africa. Journal of South African Veterinary Medical Association, v. 39, p. 81-85, 1968.

YILMAZ, H.; CRIPPS, P. J.; TURAN, N.; OZGUR, N. Y.; GREEN, L. E.; ANIL, M. H.; ILGAZ, A.; MORGAN, K. L. A postal survey of abortion in Turkish sheep. Small Ruminant Research, v. 45, p. 151-158, 2002.

ZAKERI, S.; KRORAMI, N.; GANJI, Z. F.; SEPAHIAN, N.; MALMASI, A.; GOUYA, M. M.; DJADID, N. D. Leptospira wolffii, a potential new pathogenic Leptospira species detected in human, sheep and dog. Infection, Genetics and Evolution, v. 10, p. 273-277, 2010 
ZAN BAR, T.; YEHUDA, R.; HACHAM, T.; KRUPNIK, S.; BARTOOV, B.; Influence of Campylobacter fetus subespécie fetus on ram sperm cell quality. Journal of Medical Microbiology, v. 57, p.1405-1410, 2008. 